\author{
Universidade de São Paulo \\ Instituto de Física de São Carlos
}

\title{
Caracterização, Modelagem e Simulação Matemático-Computacional da Dinâmica do Crescimento e Conexões de Células Neurais
}

Andrea Gomes Campos Bianchi

Tese de Doutorado apresentada ao Instituto de Física de São Carlos, Universidade de São Paulo, como parte dos requisitos para a obtenção do Título de Doutor em Física Aplicada.

Orientador: Luciano da Fontoura Costa 


\section{Bianchi, Andrea Gomes Campos}

Caracterização, Modelagem e Simulação MatemáticoComputacional da Dinâmica do Crescimento e Conexões de Células Neurais/Andrea Gomes Campos Bianchi - São Carlos, 2003.

$173 \mathrm{pp}$.

Tese (Doutorado) - Instituto de Física de São Carlos, 2003.

Orientador: Prof. Dr. Luciano da Fontoura Costa

1. Neuromorfometria 2. Neurociência 3. Simulação Neural 
Dedico esse trabalho ao meu marido Rodrigo e aos meus pais, Nelson e Fada, como agradecimento a todo apoio e amor recebidos. 


\section{Agradecimentos}

A Deus, pela realização de mais um sonho.

Ao incentivo e a confiança do meu orientador Prof. Dr. Luciano da F. Costa durante esses 10 últimos anos. Agradeço por todo o seu apoio e a sua participação na minha formação profissional.

A Alejandra Bosco pelas imagens de neurônios. As Profs. Marinilce F. Santos e Dânia H. Britto pela obtenção das imagens dos neurônios em crescimento.

Ao Prof. H. G. E. Hentschel pela colaboração durante meu estágio em seu laboratório em Atlanta.

Aos amigos Leandro Estrozi, Luiz Rios, Cristian, Edson e Consul pelas inúmeras discussões sobre o meu trabalho, na forma de discussões, incentivos, dicas, amizade e bom-humor. Agradecimento ao Leandro pelas imagens de esqueleto.

Às minhas amigas Sílvia, Dani, Renata, Regina e Júlia por estarem sempre presentes em todos os momentos, pelo trabalho em conjunto e pela contribuição através de inúmeras discussões que serviram para enriquecer o meu trabalho.

A todos os amigos do CVRG, os amigos mais antigos, Fátima, Alan, Jander, Odemir e os mais novos, Bárbara, Li, Bruno, Erbe, Carlos, Ricardo, Leandro, Tadeu, pela amizade e pelo ambiente de trabalho.

Aos meus amigos Patrícia e Giulio pela amizade constante.

Aos amigos Marquinhos, Leandro, Sueli, Aílton, Ivanilda e Lírio pela assistência e amizade, sempre que necessária.

Ao Rodrigo, pelo imenso carinho, compreensão e amor, em todos os momentos. Pelo enorme apoio e paciência em ler minha tese inúmeras vezes.

Aos meus pais, avós e toda minha família, pelo carinho sempre presente em todos os momentos.

Às famílias Bianchi, Moreira, Santos e Baeta por toda a ajuda.

A todos os funcionários do IFSC, incluindo as da biblioteca, e da pósgraduação, que sejam pela amizade ou pelo trabalho, contribuíram para essa tese.

E, finalmente, ao apoio financeiro da Fapesp. 


\section{Índice}

CAPÍTULO 1: INTRODUÇÃO ..........................................................

1.1 A Importância da Forma Neural .................................................................. 4

1.2 Objetivos e Apresentação da Tese (.................................................................5

CAPITULO 2: CÉLULAS NEURAIS ...........................................

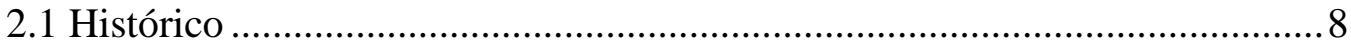

2.2 A Biologia do Neurônio ............................................................................ 12

2.2.1 Fatores Biológicos que Influenciam na Forma do Neurônio ..................................... 14

2.2.2 Mecanismos de Polimerização da Actina ........................................................... 18

CAPITTULO 3: MODELOS NEURAIS COMPUTACIONAIS............. 27

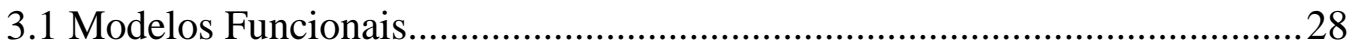

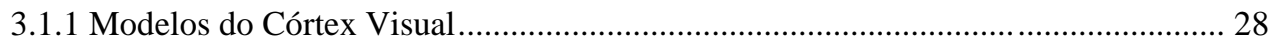

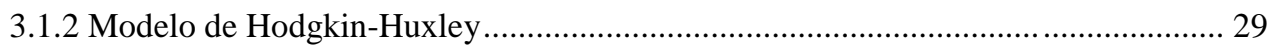

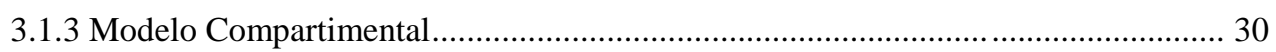

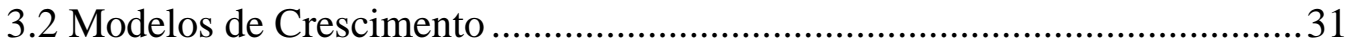

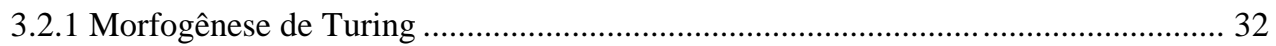

3.2.2 Modelos Relacionados a Dinâmica dos Microtúbulos e Cones de Crescimento ...... 33

3.2.3 Modelos Relacionados à Dinâmica do Filopódio...................................................... 36

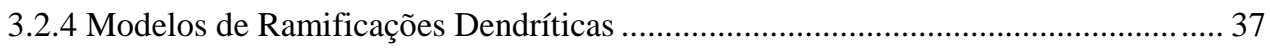

3.2.5 Modelo de Crescimento Neural ......................................................................... 43

CAPITULO 4: TÉCNICAS COMPUTACIONAIS DE EVOLUÇÃO DE

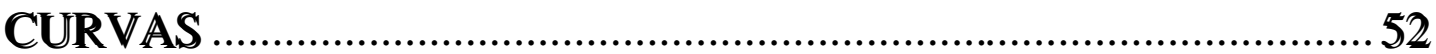

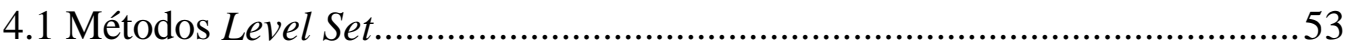

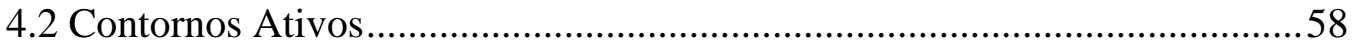

CAPITULO 5: IMAGENS NEURAIS E MEDIDAS

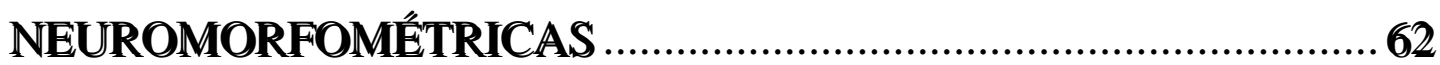

5.1 Imagens de Células Ganglionares ..........................................................62 62

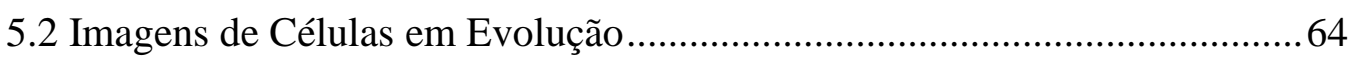

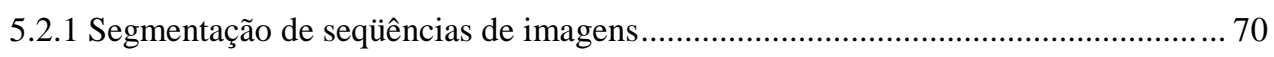

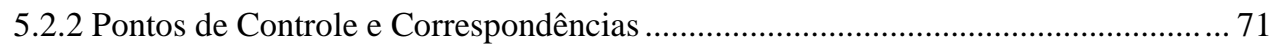




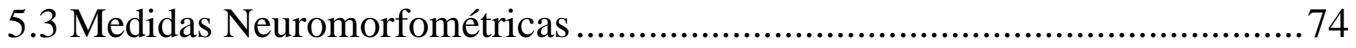

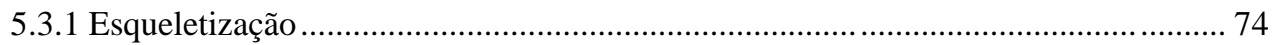

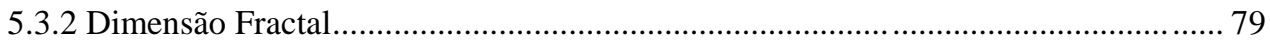

5.3.3 Dimensão Fractal de Células Neurais..................................................................... 85

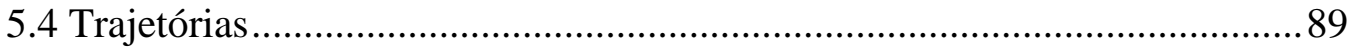

CAPITULO 6: DESENVOLVIMENTOS E RESULTADOS ............. 91

6.1 Evolução na Normal .......................................................................... 91

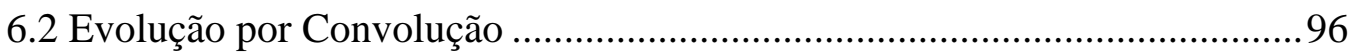

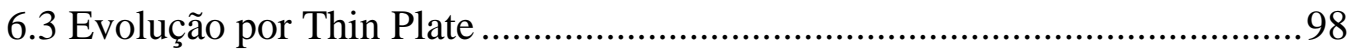

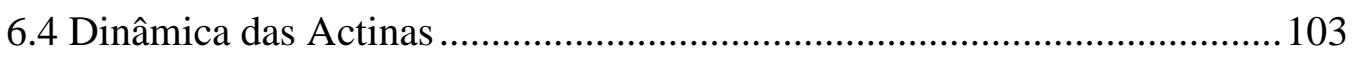

6.5 Contornos Ativos acoplado a Potencial Externo ......................................109

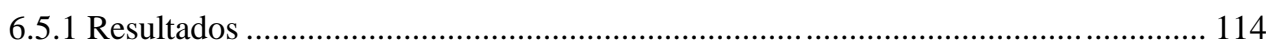

CAPITULO 7: CONCLUSÕES ….................................................. 123

7.1 Principais Contribuições.......................................................................... 127

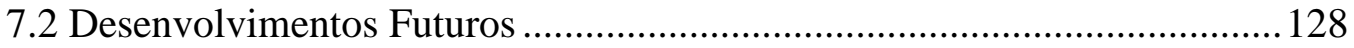

7.3 Artigos Publicados em Revistas e Conferências com Arbitragem..............129

CAPÍTULO 8: REFERÊNCIAS BIBLIOGR ÁFICAS ...................... 132 APÊNDICE A: ALGORITMO DO MODELO DE CRESCIMENTO NEURAL PROPOSTO POR HENTSCHEL, SAMUELS E FINE. .... 142 APÊNDICE B: ALGORITMO GREEDY ...................................... 1152 APÊNDICE C: ALGORITMO DE CRESCIMENTO NEURAL BASEADO EM CONTORNOS ATIVOS E POTENCIAL EXTERNO 


\section{Lista de Figuras}

Figura 1 - Desenho esquemático de um neurônio .................................................. 13

Figura 2 - Diagrama dos microtúbulos e actinas na célula [Hely(1998)]. ................. 14

Figura 3 - Esquema proposto em Pollard(2000) para a polimerização da actina no interior celular.

Figura 4- Ilustração do ângulo de crescimento das actinas na célula [Mullens(1998)]

Figura 5 - Imagem de microscopia dos ângulo entre as ramificações nos filamentos de actina [Mullens(1998)].

Figura 6 - Padrões obtidos de sistema de reação-difusão [Prusinkiewicz(1997)].....33

Figura 7 - Simulação do crescimento do neurônio, as figuras representam a variação de cálcio no interior para 1, 25, 35 e 45 iterações, respectivamente em (a), (b), (c) e (d). 50

Figura 8 - Representação básica de um processo de morphing [Costa(2001)a] .......53

Figura 9 - Curva se propagando com velocidade na direção da normal F [Sethian(1999)].

Figura 10 - Propagação de uma frente em função do tempo com velocidade constante [Sethian(1999)] 54

Figura 11 - Exemplo da propagação da frente utilizando a função $\Phi(\mathrm{t})$, onde cada evolução corresponde ao nível zero de $\Phi(t)[\operatorname{Sethian}(1999)]$.

Figura 12 - (a) Curva analítica inicial e (b) propagação da curva utilizando velocidade constante 56

Figura 13 - Propagação da curva utilizando velocidade proporcional a curvatura. ..56

Figura 14- Imagem inicial com ruído gaussiano em (a) e filtragem utilizando o método de propagação de frentes com a velocidade proporcional a curvatura em (b).

Figura 15 - (a) e (b) apresentam células ganglionares da retina do Furão na situação $C T R$, e (c) e (d) células ganglionares da retina do Furão sob a ação do NT-4. ..64

Figura 16 - Seqüência de imagens de célula em cultura. 67

Figura 17 - Sequiência de imagens durante a cultura de células. 69 
Figura 18 - Segmentação da Figura 16 usando o filtro de Sobel (a) e segmentação manual (b).

Figura 19 - Interface interativa do programa usado para definição dos pontos de controle e das correspondências entre as imagens da seqüência.

Figura 20 - (a) Imagem original do neurônio, (b) esqueleto multiescala, (c) o esqueleto para a escala 5 e (d) o dendograma para a mesma escala do esqueleto.

Figura 21 - (a) Histograma do ângulo inicial das ramificação, (b) valor de curvatura para cada ramo, (c) largura de cada ramo e (d) comprimento de cada ramificação. .77

Figura 22 - Histogramas caracterizando o número de ramificações (a), comprimento médio dos ramos (b), largura média dos ramos (c), ângulos nos pontos de ramificação (d), curvatura média (e) e ordem máxima das ramificações (f) em pixels. .78

Figura 23 - Curva de Koch. 79

Figura 24 - Contorno original e imagens dilatadas com raios iguais a 3 e 5 pixels. . 81

Figura 25 - Ilustração de uma curva de dimensão fractal da Quádrica mostrando variações do valor da dimensão fractal usando interpolação por retas.

Figura 26 - Curva de Koch original em (a), log da área vs log do raio em (b) e curva de dimensão fractal em (c) $(2-d h(r) / d r)$.

Figura 27 - Ilustração das medidas obtidas da curva de dimensão fractal [Costa(2002)]

Figura 28 - Os itens (a) e (c) apresentam imagens de neurônios sob a ação de CONTROL e (e) e (g) sob a ação de NT4, e os itens (b), (d), (f) e (h) as suas respectivas curvas de dimensão fractal.

Figura 29 - Gráfico do valor da dimensão fractal vs o raio de dilatação que ocorre esse pico para as células em CTR (vermelho), e com NT-4 (azul). 87

Figura 30 - Gráficos do valor de dimensão fractal (a), e da escala para esse valor de dimensão fractal(b)

Figura 31- Gráfico da trajetória considerando a dimensão fractal, o raio para o máximo valor da dimensão fractal e o perímetro da sequiência da Figura 5. .....90

Figura 32 - Sequiência de uma forma neural em evolução, vetor velocidade (em cinza) e campo normal (em preto). 
Figura 33- Histograma do ângulo entre a velocidade e a normal, para terminações (a), e ramificações em (b), e ângulo entre a velocidade e a horizontal (c). 95

Figura 34 - Contorno original em (a) e contorno com aplicações de gaussianas em (b) . .96

Figura 35 - Estimação dos núcleos de convolução, em azul temos as bases originais e em vermelhos as estimativas.

Figura 36 - Representação da função radial $-\mathrm{g}(\rho)$ utilizada na interpolação thin plate spline.

Figura 37 - Apresentação de uma superfície Thin Plate Spline para os pontos de controle marcados em azul.

Figura 38 - Utilização de pares de thin plate na movimentação de um dendrito do neurônio.(a) imagem do neurônio sobrepostos com pontos de controle iniciais (azul), (b) imagem sobreposta com pontos modificados (vermelho) e (c) interpolação gerada a partir do pontos considerados.

Figura 39 - Utilização de pares de thin plate pair na movimentação de um dendrito do neurônio. (a) imagem do neurônio sobrepostos com pontos de controle iniciais (azul), (b) imagem sobreposta com pontos modificados (vermelho) e (c) interpolação gerada a partir do pontos considerados. 102

Figura 40 - Interpolação usando Thin-plate para checar o mecanismo de evolução.

Figura 41 - Exemplo de uma simulação considerando a ação da força como uma gaussiana (a) e um zoom da parte onde a actina empurra a membrana (b)......108

Figura 42 - (a) Imagem inicial em azul com ponto modificado em vermelho, (b) resultado (em vermelho) da aplicação de forças de mola entre os pontos.

Figura 43 - Ilustração da soma vetorial da curvatura (em vermelho), gradiente do campo elétrico (em azul) e a resultante (em preto), onde a resultante determina a movimentação da membrana.

Figura 44 - Exemplo do laplaciano de uma distribuição de cargas circular atuando sobre uma determinada curva (em preto).

$$
\text { (b) }
$$

Figura 45 - Resultados obtidos da simulação do crescimento utilizando potencial externo e curvatura nos itens (b), (d) e (f). Os itens (a), (c) e (e),representam a figura inicial (em azul) e os campos elétricos (em vermelho). 
Figura 46 - Resultados obtidos da simulação do crescimento utilizando potencial externo e curvatura nos itens (b), (d) e (f). Os itens (a), (c) e (e) representam a figura inicial (em azul) e os campos elétricos (em vermelho)

Figura 47 - Resultados obtidos da simulação do crescimento utilizando potencial externo e curvatura nos itens (b), (d) e (f). Os itens (a), (c) e (e) representam a figura inicial (em azul) e os campos elétricos (em vermelho). 119

Figura 48 - Resultados obtidos da simulação do crescimento utilizando potencial externo e curvatura nos itens (b), (d) e (f). Os itens (a), (c) e (e) representam a figura inicial (em azul) e os campos elétricos (em vermelho)

Figura 49 - Esquema representativo do algoritmo utilizado

Figura 50- (a) Membrana inicial definida na grade e (b) matriz de ocupação da membrana.

Figura 51 - (a) Representação da matriz de concentração de cálcio, (b) representação da matriz concentração de sódio e (c) representação da matriz concentração de potássio. 146

Figura 52 - (a) Representação dos vetores normais a superfície em cada ponto $(x, y)$ da membrana, em (b) representação da direção dos vetores da proteína tubulina que definem o crescimento em cada ponto $(x, y)$ da membrana 146

Figura 53 - Imagem original com conjunto de pontos para a snake.......................152

Figura 54- Ilustração dos pontos $v(s)$ e de seus vizinhos. 153

Figura 55 - (a) Negativo do gradiente sobreposto com os pontos iniciais, (b) e (c) gradiente e imagem original sobrepostos com os pontos originais(azul) e com resultado da snake (vermelho) 157 


\section{Resumo}

Este trabalho representa continuidade no desenvolvimento de trabalhos na área de neurociência computacional, em particular na área de neuromorfometria e no relacionamento da forma-função. Os objetivos principais são a investigação e a simulação de modelos dinâmicos para o desenvolvimento de células neurais, e a caracterização da sua morfometria em termos de atributos. A tese apresenta um histórico sobre a neurociência, e uma breve revisão sobre a biologia do neurônio e sobre fatores que influenciam na variação na sua forma. Seguimos com a apresentação dos principais modelos computacionais de simulação neural, funcionais e de crescimento neural, com uma descrição mais detalhada de um modelo de crescimento baseado na atuação do cálcio como agente morfogênico e também na polimerização de actinas. Como uma introdução à modelagem neural, discutimos técnicas computacionais de evolução de contornos que podem ser utilizadas na simulação do desenvolvimento neural, propagação de frentes e contornos ativos. Apresentamos também medidas neuromorfométricas tais como a dimensão fractal multiescala, e medidas extraídas a partir do esqueleto da imagem do neurônio, tais como largura, espessura, número de ramos e curvatura das ramificações. Apresentamos os resultados obtidos em diferentes hipóteses de desenvolvimento de células neurais. Foram propostos crescimentos baseados na normal (velocidade na direção normal a curva), convolução, thin plate splines e dinâmica da polimerização da actina. Além disso, foi proposta uma nova abordagem para a evolução da membrana neural baseada em contornos, utilizando a formulação de contornos ativos sob a ação do campo elétrico externo e a curvatura da forma, o que possibilitou a geração de estruturas com características muito semelhantes a do neurônio, inclusive com ramificações. Finalizamos o trabalho apresentando os resultados e conclusões obtidas para os modelos de desenvolvimento. 


\begin{abstract}
In this thesis we report the investigation and simulation of dynamic models of neural growing, and their characterization using shape features, considering the formfunction relationship and neuromorphometry. The thesis begins by presenting an overview about neuroscience, neural cell biology and the biological factors that affects the neuron form developments, followed by the presentation of computational neuronal models based on electrophisiological measures and development models of internal structures as actin and microtubules. Special attention is devoted to a neuron growth model based on calcium as a morphogen, whose main characteristic is its electric activity at the membrane. Regarding mathematical models of neural development, two different approaches of contour evolutions are presented, Level Set Methods and Active Contours. Some neuromorphometric measures are implemented and discussed as features for classification and neural evolution, including the multiscale fractal dimension, and dendrite measurements are obtained by using neuron skeletons. In agreement with biological form influences, some hypotheses about development of neuron growth are proposed based on evolution rules, such as: normal evolution (based in normal velocity), convolution, thin plate splines and actin polimerization. A new approach about neuron development is also proposed: a contour based technique that makes use of active contour formulation, Snake Balloon, where the membrane velocity and direction suffers influences of internal and external factors, such as electrical field with diferent geometries, and contour curvature. Both hypotheses are in accordance with the biological factors that influences the neuron form. The simulation produces similar neuron-like structures, even with ramification of certain dendrites.
\end{abstract}




\section{CAPÍTULO 1: INTRODUÇÃO}

Nas últimas décadas as pesquisas relacionadas às áreas de neurociência e neurobiologia vêm aumentando gradativamente, uma vez que o cérebro e suas áreas relacionadas caracterizam-se por diversos aspectos ainda desconhecidos. Uma das dificuldades dessa pesquisa é a grande diversidade dos neurônios quanto a sua forma e a sua função, tornando complexas as tarefas de correlação entre a aquisição de dados neurológicos, a exatidão quanto à função desempenhada e a morfologia apresentada por cada neurônio. A complexidade do sistema nervoso ainda caracteriza-se como uma barreira ao entendimento de muitos processos do cérebro. Dentro desse contexto, as dificuldades encontradas acabaram impulsionando o desenvolvimento da área de neurociência computacional, que se destina a simulações matemáticas e computacionais do comportamento do sistema nervoso, e que vêm se mostrando uma poderosa ferramenta de análise, aliada à biologia, no entendimento dos processos celulares.

Durante muitos anos as medidas eletrofisiológicas e os aspectos eletroquímicos dos neurônios foram os principais dados biológicos utilizados nos modelos de simulações dos impulsos nervosos ao longo dos axônios, como é o caso da teoria do Cabo [Koch(1989)] e dos modelos Compartimental [Koch(1989)] e de HodgkinHuxley [Sheperd(1994)]. Entretanto, apesar dos bons resultados obtidos, essas simulações não possuem nenhum compromisso quanto à forma, orientação ou posição relativa das células neurais. $\mathrm{Na}$ verdade, relativamente pouco se estuda a respeito da forma dos neurônios. Existem muitas evidências biológicas que corroboram com a idéia da importância da forma neural e do seu relacionamento com a sua função. Apesar dessas evidências, apenas alguns pesquisadores se interessavam por essa área, [Montague(1991), Toris(1995) e Costa(1997)], seja através de medidas como dimensão fractal, área de influência, número de ramificações dendríticas, e comprimento e diâmetro de segmentos, ou seja construindo modelos que levassem em conta o desenvolvimento e a forma do neurônio [Samuels(1996), Coelho(1998), Hely(1998) e Van Ooyen(1999)]. 
Atualmente a neurociência vem se preocupando tanto com uma nova linha de pesquisa que estuda a morfologia e a classificação do neurônio através de medidas extraídas da célula, denominada análise neuromorfométrica, quanto com o desenvolvimento da célula neural e o seu relacionamento com a função a ser desempenhada. $\mathrm{O}$ advento de novas técnicas de captação de imagens através de microscópios confocais (imagens 3D), de força atômica, dentre outras, tornaram possíveis diferentes abordagens a neuromorfometria e ao desenvolvimento de modelos neurais mais realistas, pois as imagens de alta definição possibilitaram um melhor entendimento do funcionamento do neurônio. Assim, grande parte das simulações apresentam algum tipo de característica que os tornam mais realistas, tanto no que diz respeito a morfologia do neurônio, quanto nas ligações sinápticas e nas funções a serem por eles desempenhadas. Isso também possibilitou o surgimento de modelos que simulassem o seu crescimento e o seu desenvolvimento, ao invés de estudar apenas o seu comportamento fisiológico.

Desde 1993 o Grupo de Pesquisa em Visão Cibernética do IFSC vem se dedicando a neuromorfometria e ao estudo da influência da forma na função neural, visando gerar estruturas neurais biologicamente mais realistas. Os objetivos e o plano geral que têm justificado tais desenvolvimentos foram inicialmente enunciados na tese de livre-docência [Costa(1997)], que focaliza a investigação do relacionamento entre a geometria de estruturas neurais em diversas escalas espaciais e as respectivas funcionalidades, e vice-versa. Após caracterizar a falta de medidas morfométricas abrangentes e adequadas para a caracterização da rica e variada geometria das estruturas neurais, aquela tese propõe que o primeiro passo no estudo da relação entre forma e função neural consiste na proposta, implementação e validação de medidas efetivas para a caracterização da forma de neurônios e da distribuição espacial dos mesmos. Passos subseqüentes em tal plano geral de pesquisa, a ser desenvolvido em longo prazo, envolvem a concepção de modelos neuromórficos integrando função e forma neural, assim como a respectiva simulação e validação através de comparações com resultados experimentais, utilizando as medidas morfológicas adequadas. Tais princípios fundamentam o plano e filosofia principais da presente tese. Dentro desse contexto, já foram propostas um conjunto de medidas que possibilitaram a caracterização de células neurais, tais como, a curvatura[Cesar(1995)], a energia de dobramento [Cesar(1997)], o campo vetorial 
[Costa(1999)c], a área de influência [Coelho(1998)] e a complexidade espacial [Coelho(1996)]. Essas medidas neurais possibilitaram uma classificação mais quantitativa das células neurais [Costa(1998), Costa(1999)b, Costa(2000)a] e a construção de dendrogramas [Cesar(1999)], isto é, estruturas capazes de representar a hierarquia das arborizações dendríticas e axonais de um neurônio. Concomitantemente a esse trabalho, o grupo também investiu na criação de modelos neurais. Um primeiro trabalho focalizando modelos neuromórficos foi relatado em [Costa(1994)], que investigou a importância da distribuição espacial de neurônios ao longo de espaços topográficos para análise de estímulos visuais, mais especificamente a simulação de campos receptivos do tipo simples. Em seguida, foi proposto um modelo baseado na geração de neurônios artificiais que apresentassem estruturas morfológicas semelhantes as naturais [Coelho(1998), Coelho(2002)], onde as estruturas geradas eram baseadas em medidas estatísticas obtidas de células ganglionares adultas da retina do gato. Uma outra abordagem foi a proposta de um modelo para estimativa da curvatura e orientação, baseados em propriedades eletrofisiológicas do neurônio adulto e em características morfológicas da rede neural, investigando em maiores detalhes a influência da morfologia dos neurônios sobre as medidas de curvatura e orientação[Tanaka(2000)].

Entretanto, apesar dos bons resultados encontrados pelos modelos descritos acima, eles consideram apenas o neurônio em sua fase adulta, ou seja, não se interessam nem em descobrir quais os fatores que levaram a célula a possuir uma determinada forma, e nem tampouco como acontece esse processo de evolução neural. Desse modo, o estudo e o entendimento do processo de crescimento celular contribuiria não somente para explicar o crescimento do neurônio, mas também para uma maior compreensão sobre a sua "história", sobre a criação das suas conexões celulares e sobre a função a ser por ele desempenhada, convergindo para um detalhamento mais completo dos princípios de funcionamento do cérebro. $\mathrm{O}$ trabalho proposto nesta tese trata exatamente de modelos de crescimento neural, através de uma nova abordagem baseada em evolução de contornos para a forma neural, e não através das abordagens usualmente adotados na literatura, que descrevem características funcionais, ou de desenvolvimento de filamentos de actina e microtubulinas no neurônio. Para isso são investigados quais os fatores biológicos que influenciam na determinação da forma e quais dessas hipóteses podem ser 
incorporadas a um modelo de desenvolvimento que possibilite a geração de estruturas ramificadas semelhantes a dos neurônios.

\subsection{A Importância da Forma Neural}

O nosso cérebro possui uma grande diversidade de formas de células neurais, essa variedade leva-nos a acreditar que essa variação na forma neural ocupa um papel importante na definição da função que o neurônio irá desempenhar, proposta também defendida por inúmeros pesquisadores da área biológica [Lasek(1986), Purves(1988), Purves(1990), Evans(1989), Costa(1997)]. Apesar disso, grande parte dos modelos computacionais de simulação neural existentes praticamente ignoram dados relacionados à forma do neurônio. Acreditamos que estudar o desenvolvimento e o comportamento da evolução dos neurônios relacionados a sua morfologia pode se tornar uma importante ferramenta para o entendimento do funcionamento do cérebro. Algumas evidências fortalecem a hipótese da relação entre a forma e a função neural, uma vez que a distribuição espacial da arborização irá determinar quais vizinhos irão se conectar a um determinado neurônio, e qual o número de sinais de entrada que essa célula irá receber, afetando diretamente suas propriedades funcionais.

De acordo com os trabalhos desenvolvidos por Lasek(1986), a forma do neurônio determina o modo como a informação é espacialmente distribuída no organismo, além da determinação das rotas de transmissão de informação e da importância que a forma das ramificações exerce no modo como os sinais elétricos são processados e transmitidos. Por exemplo, o diâmetro de um axônio ou dendrito determina as suas propriedades de cabo, e estas por sua vez afetam o espalhamento do potencial ao longo do neurônio, gerando grandes indícios da sua influência na função neural. Uma outra evidência foi proposta no trabalho de [Wässle(1986)] com células ganglionares da retina, onde se verificou experimentalmente que o campo receptivo destas células estaria ligado a área ocupada pela arborização dendrítica. No mesmo ano, outros trabalhos desenvolvidos por [Burke(1986), Rall(1986) e Shepherd(1986)], em [Lasek(1986)] apresentam exemplos que corroboraram com o fato de que a forma neural afeta a condução e o processamento das informações elétricas. 
De modo geral, podemos entender que a variação da forma dendrítica pode mudar não somente o número de entradas que o neurônio recebe, mas também as características das suas atividades e a maneira na qual eles integram a informação sináptica, evidenciando não só a importância do estudo de modelos de evolução de células neurais e suas conexões, mas também a inclusão da forma do neurônio em simulações funcionais e eletrofisiológicas.

\subsection{Objetivos e Apresentação da Tese}

Dentro desse contexto, baseados nas evidências sobre a importância da inclusão da forma de neurônios como uma ferramenta ao entendimento das estruturas do cérebro, o objetivo principal desse trabalho consiste na investigação e desenvolvimento da dinâmica envolvida no crescimento de células neurais. $O$ trabalho investiga a caracterização, a modelagem e a simulação de diversas hipóteses de desenvolvimento de células neurais sob a ação de fatores internos (curvatura) e externos (difusão e campo elétrico), além de investigar a especialização morfológica dos neurônios. Sendo assim, esse trabalho apresenta duas linhas principais de pesquisa: (i) o estudo de modelos dinâmicos, baseados em contornos, aplicados ao crescimento de neurônios e (ii) a caracterização da morfometria neural através da descrição de diversas medidas celulares, incluindo a dimensão fractal e medidas obtidas através de seus esqueletos. $\mathrm{O}$ modelo de crescimento proposto possui uma abordagem baseada em contornos, ou seja, a hipótese principal é que a membrana neural seja considerada como uma curva fechada, cujas posições $(x, y)$ variam ao longo do tempo. A formulação matemática da sua evolução se dá através de técnicas computacionais de propagação de contornos, enquanto as hipóteses de crescimento adotadas estão intimamente ligadas a fatores biológicos que influenciam no crescimento de células neurais.

Devido ao caráter multidisciplinar desta tese, o Capítulo 2 se inicia apresentando um breve histórico sobre a neurociência, a descoberta do neurônio e sua importância, seguindo com um resumo sobre a biologia do neurônio e destacando quais os fatores biológicos que influenciam na variação da sua forma. Apresentamos também uma descrição mais detalhada dos mecanismos de polimerização dos microfilamentos de 
actina, como essa polimerização acontece, quais as regras desse crescimento e como ela influencia na membrana, de modo que sua forma possa ser modificada.

No Capítulo 3 apresentamos uma breve descrição sobre os modelos de simulação neural mais importantes. Eles foram separados em duas grandes áreas: modelos funcionais, abordando simulações dos impulsos nervosos, e modelos de crescimento neural, intimamente ligados com a forma neural e a fatores biológicos que influenciam diretamente no crescimento do neurônio. Neste capítulo destacamos ainda o modelo desenvolvido por Samuels, Hentschel e Fine [Samuels(1996)], cujo crescimento está baseado na variação da concentração de cálcio do neurônio, e cujas idéias caracterizam-no como um modelo bem realista. Além do cálcio, o modelo também considera outras características importantes do neurônio, com a idéia da membrana eletricamente ativa sob a ação de canais iônicos e de bombas de íons.

Em seguida, no Capítulo 4, são apresentadas técnicas de evolução de curvas e superfícies utilizadas em processamento de imagens. São descritos os métodos Level Set, de propagação de frentes proposto por Sethian [Sethian(1999)] e a técnica de contornos ativos, desenvolvida por Kass [Kass(1987)]. Elas possuem um grande potencial para serem utilizados na investigação da dinâmica do crescimento, pois se caracterizam como técnicas poderosas e robustas no tratamento de evolução de contornos, além de conseguirem eliminar vários problemas ocasionados durante uma propagação de contornos e presentes em outras importantes técnicas, como, por exemplo, problemas na topologia da curva.

O Capítulo 5 é relacionado a neuromorfometria das células, ou mais especificamente, na extração de medidas de imagens de células neurais. Ele pode ser dividido em duas partes: (i) a obtenção e pré-processamento das imagens de neurônios (células adultas e células em crescimento) e (ii) a descrição de medidas neuromorfométricas, a dimensão fractal e as medidas que são calculadas através do esqueleto da imagem da célula. As imagens reais das células neurais em crescimento possibilitaram a verificação de algumas das hipóteses de evolução propostas no trabalho. No caso das medidas neuromorfométricas, apresentamos o conceito da esqueletização usando dilatações exatas e a sua utilização na extração de características (features) dos neurônios (tamanho, largura, curvatura e ângulo de cada ramificação). Além disso, apresentamos o conceito de fractalidade e de dimensão fractal multiescala aplicada em células neurais. O cálculo da dimensão fractal foi 
aperfeiçoado com a utilização da dilatação exata, e também pela análise do comportamento fractal ao longo das escalas (raios de dilatação), o que denominamos convenientemente de fractal multiescala.

As descrições sobre as hipóteses de evolução que regem o crescimento de uma célula neural biológica e o modelo de crescimento proposto podem ser encontrados no Capítulo 6, assim como seus respectivos resultados. As hipóteses de crescimento adotadas foram o crescimento na normal, onde a velocidade de crescimento encontra-se na direção da normal à curva, evolução por thin plate spline, supondo que função possua restrições de suavidade e, por último, por convolução, onde o objetivo era buscar a base de funções (kernel) utilizadas para a evolução da curva. $\mathrm{O}$ capítulo é finalizado com a apresentação de uma idéia simplificada sobre o crescimento de actinas e com o desenvolvimento de um modelo de crescimento de células neurais que considera a membrana como um contorno e utiliza-se da formulação de contornos ativos (Snake Ballon) para descrever o seu desenvolvimento. As regras de evolução são baseadas em curvatura do contorno e na ação de elétrico externo (com geometrias diversas), conceitos que são facilmente extrapolados para a biologia associada ao problema. Foram apresentados os resultados das simulações, as estruturas ramificadas semelhantes a células neurais, e também a variação das simulações sob a ação campos com diversas geometrias. Finalizamos, com o Capítulo 7, apresentando algumas discussões sobre os resultados obtidos, as contribuições desse trabalho, e algumas sugestões para trabalhos futuros. Portanto, nesse trabalho apresentamos um estudo do crescimento neural desde a descrição de um modelo baseado na evolução do seu contorno, até as medidas capazes de caracterizá-los, passando por todas as etapas de elaboração de métodos computacionais e programas, obtenção das imagens de crescimento, aprimoramento dos métodos de neuromorfometria e propostas de novos modelos baseados na biologia do neurônio. 


\section{CAPÍTULO 2: CÉLULAS NEURAIS}

Esse trabalho possui uma característica intrínseca relacionada a multidisciplinaridade entre as áreas de Física, Computação e Biologia, pois engloba hipóteses biológicas para o crescimento de células neurais e a sua modelagem através de técnicas computacionais de evolução de curvas. Desse modo, percebemos a necessidade de realizar uma revisão sobre alguns conceitos básicos, tanto sobre a biologia do neurônio, quanto sobre modelos neurais e técnicas de evolução que serão utilizados ao longo do texto. É muito importante contextualizar os assuntos a serem tratados e a sua relação com o modelo a ser apresentado.

Baseados neste contexto, esse Capítulo apresenta os primeiros conceitos sobre a estrutura do cérebro, a sua importância e o seu funcionamento, juntamente com as idéias inicialmente concebidas do período de 1700 a.C. a 1800 d.C., extraídas basicamente de Kandel(1985), além das pesquisas mais recentes desenvolvidas na área nos últimos anos. Também destacamos as principais características da biologia do neurônio e uma descrição dos fatores biológicos que influenciam a variação de suas formas, com especial atenção ao modelo de crescimento de actinas no interior celular proposto por Pollard(2000), que é atualmente o modelo mais aceito em biologia. $\mathrm{O}$ entendimento e a discriminação dos principais fatores de crescimento que influenciam na forma neural é muito importante, uma vez que essas características serão, posteriormente, incluídas e simuladas nos modelos de evolução da célula neural.

\subsection{Histórico}

\section{- Período de 1700 a.C. a 1800 d.C.}

Nem sempre o cérebro foi uma estrutura muito bem conceituada no meio científico, e um bom exemplo disso é que, na antiguidade, os filósofos gregos achavam que o coração, e não o cérebro, era o responsável pela inteligência dos seres humanos. 
Também os egípcios não mostravam muito interesse pelo cérebro. Relatos mostram que, durante a mumificação, este era retirado e desprezado, enquanto o coração e outros orgãos eram removidos e preservados, como sinal da sua importância. No entanto, curiosamente, os egípcios são os responsáveis pelos registros mais antigos sobre a anatomia do cérebro. Nesses estudos, o cérebro era dividido basicamente em duas partes, a meninge (cérebro) e o líquido cérebro espinhal. Tal descrição surgiu por volta de 1700 a.C. em um papiro conhecido como Edwin Smith Surgical Papyrus. Baseado em textos mais antigos, por volta de 3000 a.C., ele é considerado o primeiro documento médico da história e existe uma possibilidade de que ele tenha sido escrito por Imhotep, famoso médico egípcio. O documento apresenta 48 casos descritos por cirurgiões egípcios da época, sendo muitos deles relacionados ao cérebro.

Entretanto, foi somente a partir de 500 a.C. que os cientistas passaram a acreditar que o cérebro era o centro das sensações e da inteligência, através dos trabalhos de Alcmeon de Cróton, que dissecava nervos sensoriais e estudava a visão através do nervo ótico; e de Hipócrates (460 a.C.), que discutia distúrbios cerebrais e estudava casos de epilepsia. Anos depois, em 387 a.C., sob a influência das idéias de Platão, passou-se a acreditar que o cérebro era também o centro do processo mental e controlava todo o resto do corpo. Aristóteles, em 335 a.C., voltou a afirmar que o coração era o centro das sensações, desconsiderando evidências que atestassem o contrário, apesar de ser considerado discípulo de Platão.

Durante o período de 330 a 280 a.C., Herófilos, considerado o pai da anatomia, realizou um estudo sistemático da estrutura do corpo humano, apresentando a primeira descrição precisa do cérebro e concluindo que os ventrículos o dominavam. Em 280 a.C., Erasistrates observou a anatomia das divisões e convoluções no cérebro, realizando comparações do cérebro humano com o de outros animais. Em 177 d.C., Galeno sagrou-se uma figura muito importante da clínica médica, distinguindo os nervos sensoriais dos nervos motores e descrevendo em detalhes os ventrículos do cérebro. Entretanto, após a morte de Galeno, a ciência e a medicina grega ficaram praticamente esquecidas por aproximadamente 1200 anos, ou seja, durante toda Idade Média, devido, principalmente, as proibições impostas pela igreja às dissecações ou qualquer tipo de estudo mais profundo no corpo humano. Além disso, nessa época ainda acreditava-se que o cérebro era muito sujo para manter o 
conhecimento e a alma do ser humano, o que impossibilitou cada vez mais um estudo experimental minucioso desse orgão.

Foi apenas por volta de 1500 d.C. que o cérebro voltou a se destacar como objeto importante de estudos aos cientistas. Nessa época, Leonardo da Vinci criou uma estrutura em cera dos ventrículos humanos. A partir de então se sucederam inúmeras descobertas sobre o cérebro e suas estruturas, como por exemplo à glândula pineal, seguindo a análise de inúmeras outras partes do cérebro. Em 1564 Aranzi atribui o nome ao hipocampo, e em 1587 fez distinção entre o córtex e a matéria branca. Porém, apesar de todas as experiências e pesquisas, foi apenas em 1573, que Constanzo Varolio realizou o primeiro corte do cérebro começando da sua base, gerando uma nova visão deste.

Em 1649, René Descartes volta a discutir a função da glândula pineal e a descreveu como centro controlador do corpo e da mente, publicando sua teoria na obra 'O Homem'. Em 1665, a área biológica sofre um grande avanço com o detalhamento do funcionamento do primeiro microscópio por Robert Hooke, o que possibilitou uma análise mas precisa do cérebro e de outras estruturas do corpo humano. A partir de então foram inúmeros os avanços nas áreas biológicas, principalmente no que diz respeito à anatomia do cérebro. Em 1717, com o uso do microscópio ótico, Antony van Leeuwenhoek descreve a seção de um corte transversal da fibra nervosa. Em 1791, Luigi Galvani inicia os experimentos elétricos com as fibras nervosas e publica um trabalho de simulações elétricas nos nervos de sapos, dando início aos experimentos eletrofisiológicos.

\section{- $\quad$ Período de 1800 até a atualidade}

A partir de 1800 a história da neurociência sofre grandes mudanças com o surgimento das teorias para as células individuais no córtex. Em 1836, Jan Purkinje, um grande fisiologista tcheco, publicou observações de suas pesquisas sobre as células do cerebelo, onde notou que sua estrutura ia além do núcleo e do citoplasma, identificando ramificações até então desconhecidas. Robert Remak, em 1838, sugere que as células nervosas e suas fibras formam uma única célula. Em 1839, Theodor Schwann propõe a teoria celular, identificando a célula como uma partícula fundamental nas plantas e animais. Todavia, foi apenas em 1865 que Otto Deiters 
escreveu suas observações sobre um neurônio motor da corda espinhal, e apresentou dois tipos de fibras diferentes que saíam do soma; uma delas como ramificações provenientes do corpo celular que se parecia com prolongamentos deste, e o outro tipo como uma única fibra cilíndrica, sem ramificações, que provinha de uma porção do corpo celular, deixava a espinha e entrava no nervo periférico comandando os músculos. Essas prolongações ramificadas vieram a ser denominadas de dendritos, termo botânico que significa ramificações; e o eixo cilíndrico de axônio.

A grande dificuldade das pesquisas na época era que um neurônio isolado não era uma célula conhecida, pois a visualização de suas ramificações era praticamente impossível de serem observadas, fato que originou especulações sobre como seria a organização celular dos neurônios. Em 1873, Camillo Golgi [Kandel(1985)], um médico italiano, realizou experimentos tentando buscar um método melhor de visualizar as células nervosas, e apresenta o seu primeiro trabalho baseado em métodos de impregnação de nitrato de prata. Com essa técnica, apenas algumas células tinham o seu corpo celular e dendritos tingidos, proporcionando um estudo da morfologia do neurônio. No início, sua técnica causou pouco interesse entre os anatomistas e foi apenas em 1888, com Santiago Ramón y Cajal, um histologista espanhol, que a sua descoberta teve implicações mais profundas. Cajal trabalhou com muito empenho utilizando a técnica de Golgi em muitas partes do sistema nervoso e em várias espécies animais. Ele conseguiu descobrir que a entidade tingida pela técnica era de fato uma célula nervosa e que era uma entidade única e separada das outras. Ele também deduziu os princípios básicos de transmissão de sinais através dos dendritos e dos axônios e o local de contato entre eles. Cajal foi um dos primeiros pesquisadores a propor uma relação entre a forma e a função neural, a partir de um estudo minucioso sobre a morfologia das células neurais através de seus vários desenhos, conhecidos e utilizados até hoje. Como resultado a essas descobertas, em 1906 Cajal e Golgi foram laureados com o prêmio Nobel de Medicina pelos seus trabalhos em estruturas e funções dos neurônios. A partir daí, o estudo do cérebro não parou de se desenvolver, o que ocasionou grandes descobertas científicas, como o eletroencefalograma, a transmissão de impulsos químicos, a diferenciação entre os neurônios, os neurotransmissores, dentre outras.

A prova final para a aceitação dos neurônios como células individuais, mostrando que as membranas funcionavam como uma barreira para o citoplasma de 
uma célula individual, foi conseguida com o aumento da resolução dos microscópios e com o advento da microscopia eletrônica em meados de 1950. Atualmente, os microscópios confocais e os de força atômica proporcionam, respectivamente, imagens de alta resolução em diferentes alturas focais da imagem, e imagens com nível atômico de estruturas vivas e em atividade celular, possibilitando novas descobertas e contribuições importantes no desenvolvimento da neurociência.

\subsection{A Biologia do Neurônio}

O sistema nervoso dos humanos divide-se em Sistema Nervoso Central (cérebro e medula espinhal) e Sistema Nervoso Periférico (somático e autônomo). Os neurônios são células que se localizam, em grande parte, no cérebro e na medula espinhal. Eles caracterizam-se como células especializadas em transmitir informações de um ponto a outro do corpo através de processos eletroquímicos. Além dos neurônios, existem no cérebro outras células, conhecidas como células gliais, que ocupam os espaços entre os neurônios e são responsáveis pelo revestimento, isolamento, modulação dos sinais, dentre outras atividades [Sheperd(1994)].

Os neurônios possuem toda a estrutura de uma célula normal (membrana, núcleo, citoplasma e organelas). Eles têm uma região que é denominada corpo celular ou soma, e outras estruturas ramificadas especializadas chamados dendritos e axônios, Figura 1. Enquanto os dendritos são responsáveis por trazer informações até o corpo celular, os axônios levam essa informação para fora dele [Levitan(1997), Alberts(1994)]. A passagem de informação de um neurônio para outro acontece através das sinapses, pequenos intervalos separando dois neurônios. Ela acontece através de substâncias químicas que passam de um neurônio a outro, denominadas neurotransmissores. 


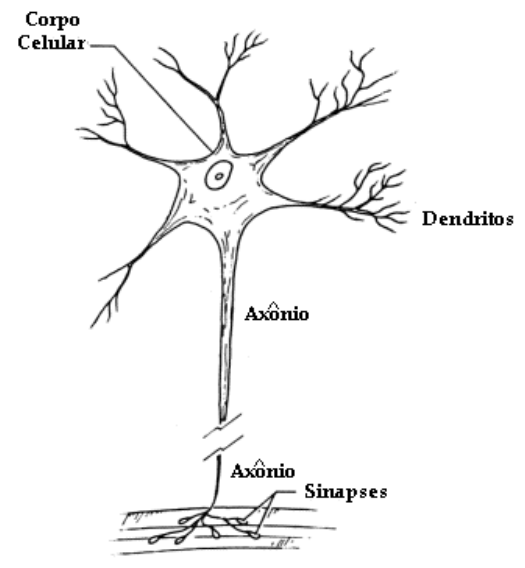

Figura 1 - Desenho esquemático de um neurônio

O sistema nervoso pode ser caracterizado pelo padrão do seu circuito neural. Esses padrões são definidos pela forma particular de uma célula neural e pelas suas conexões [Lasek(1986)]. Além da sua tendência inerente de gerar uma determinada forma e pela informação armazenada no DNA celular, os neurônios também são o resultado da ação de substâncias externas a célula. Desse modo, tanto as influências internas, quanto às externas da célula são características importantes a serem investigadas. Acredita-se que o número total de neurônios no cérebro seja da ordem de $10^{11}$ células, com $10^{4}$ sinapses cada. Entretanto, o número de genes é da ordem de 30.000, ou seja, apenas os genes são insuficientes para especificar a exata conectividade ou posição de cada uma das células.

$\mathrm{Na}$ estrutura neural, o termo neurito é muito utilizado para descrever prolongamentos celulares, tanto um axônio como um dendrito. Essa denominação é particularmente útil quando não se tem ainda bem estabelecido se o processo de crescimento irá gerar um axônio ou um dendrito. A principal característica da arquitetura neural é o prolongamento desses neuritos, que em termos biológicos são um conjunto de polímeros alinhados, denominados citoesqueleto, envolvidos por uma membrana eletricamente ativa. O citoesqueleto de uma célula é uma rede de estruturas em forma de filamento que são responsáveis pela estruturação da célula e, conseqüentemente, pela sua forma. Esse agrupamento de fibras do citoesqueleto, juntamente com as organelas, é denominado de matriz citoplasmática ou citomatriz e são os responsáveis pela base estrutural do axônio e pela arquitetura dendrítica. Existem três tipos de polímeros na citomatriz, o microfilamento, o microtúbulo, e o 
neurofilamento que são, respectivamente, formados por subunidades de actina, tubulina e proteínas de neurofilamento [Lasek(1986)]. A Figura 2 apresenta um esquema da distribuição desses polímeros na célula neural. Podemos observar que a estrutura principal de um prolongamento, ou seja, o axônio, é formado por um conjunto de microtúbulos (pacote), enquanto os filopódios (estruturas finas e longas) por filamentos de actina. É nessa estrutura que se encontram os cones de crescimento, que são estruturas especializadas localizadas nas extremidades dos filopódios e utilizadas para guiar ou direcionar o crescimento de uma ramificação de acordo com sinais extra ou intracelulares.

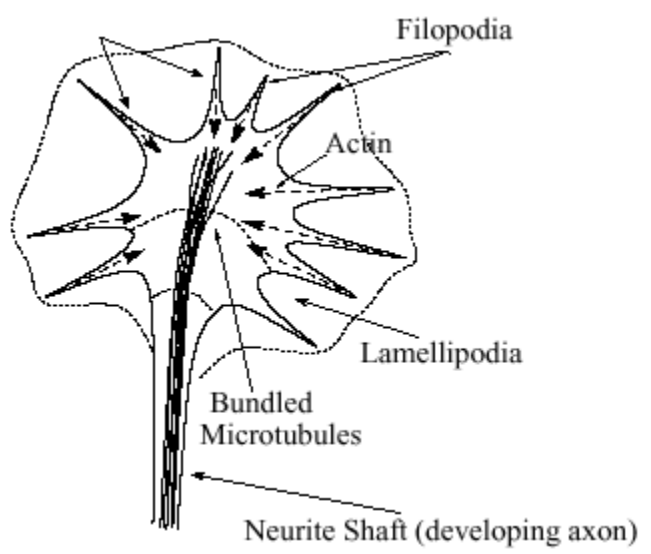

Figura 2 - Diagrama dos microtúbulos e actinas na célula [Hely(1998)].

\subsubsection{Fatores Biológicos que Influenciam na Forma do Neurônio}

A expressão gênica contida no DNA celular do neurônio é responsável por transferir informações sobre sua morfologia celular. Porém, como comentado anteriormente, apenas essas características não são suficientes para especificar totalmente a célula. Acredita-se que existam forças externas do meio-ambiente celular que guiam o desenvolvimento do neurônio e modificam sua arquitetura. Podemos destacar dois fatores principais que influenciam na forma final do neurônio:

a) O meio extracelular: uma célula é cercada de uma dezena de outras células desde o seu nascimento até sua morte. As células vizinhas possuem partículas químicas em sua superfície, que ficam constantemente mudando o meio químico. Como resultado, esses fatores afetam diretamente o desenvolvimento da célula. 
b) Resposta local a um sinal: a maior ou menor concentração de uma determinada substância no meio pode variar o crescimento do citoesqueleto celular, mas apenas uma determinada porção da célula responde a essa variação. A ramificação pode ser uma resposta a várias modificações locais discretas. Desse modo, o padrão de formas neurais gerado localmente ou é um reflexo direto aos padrões espaciais de sinais do ambiente [Lasek(1986)], ou pode simplesmente redirecionar a modificação de crescimento através de campos elétricos.

Os axônios e dendritos possuem diferentes constituições. Os axônios são formados em sua grande parte por microtúbulos e ramificações menores (filopódios), enquanto os dendritos são formados em sua grande parte por actinas. Desse modo elas possuem respostas diferentes aos fatores de crescimento. Ambos são responsáveis pela estrutura e pela forma final de uma célula neural. Logo, é de se esperar que essas estruturas respondam de forma diferente ou não, sob as mesmas situações e condições de matriz extracelular. A seguir, descreveremos os fatores de crescimento que atuam em cada uma dessas estruturas.

\section{a) Axônios}

Os axônios são estruturas alongadas semelhantes aos dendritos, podem ser maiores ou não e são os responsáveis por levar informações do corpo celular até outras células através das sinapses. Notamos que ele é formado em grande parte por microtúbulos e a sua função é totalmente diferente dos dendritos.

A estrutura responsável pela movimentação e direcionamento dos axônios é o cone de crescimento e sua principal característica é transformar células isoladas em uma rede de células interconectadas funcionalmente ativas. Os cones de crescimento estão localizados nas pontas do axônio em desenvolvimento e participam de 2 dos 3 estágios de formação de conexão. São eles: o encontro da rota (route finding), a seleção do alvo (target selection) e o refinamento das conexões (connection refinement). Cada um desses estágios possui diferentes características e ação de fatores de crescimento biológicos distintos. A seguir descreveremos os detalhes desses processos. 


\section{a.1) Encontro da Rota}

Caracteriza-se como sendo o caminho percorrido pelo axônio ao longo de uma determinada rota, a qual irá levá-lo para uma região específica do embrião. Uma das primeiras hipóteses para que isso aconteça é o estereotropismo, ou orientação por contato. Nesse caso, colas no substrato, tais como canais nas camadas celulares, servem para direcionar o crescimento de migração dos axônios. Em alguns casos, esse canais servem como uma barreira física para a prevenção da extensão dos cones de crescimento até que a área alvo esteja pronta para receber os axônios.

Em adição a movimentação pelos canais, a matriz extracelular também pode guiar um cone de crescimento por ação de um gradiente adesivo. Se a matriz extracelular é extensa, ela pode permitir o crescimento do axônio em várias direções. Desse modo, um gradiente adesivo pode tomar uma direção mais preferencial que outra. Esses gradientes adesivos são moléculas de uma determinada substância (fascilina, laminina) que influenciam na rota a ser tomada pelo axônio.

Os campos elétricos também foram observados como atuantes na definição do estabelecimento de padrões embrionários e também na influência na direção dos neuritos [Lasek(1986), Levitan(1997), Hely(1998), Matus(2000) e Van Ooyen(2001)]. O mecanismo envolve a redistribuição das proteínas de membrana com o cone de crescimento, que migram em direção ao cátodo negativo. Isso aumenta o número de receptores, na face da membrana, resultando em um aumento do número de filopódios e conseqüentemente em um direcionamento dos neuritos.

\section{a.2) Seleção do Alvo}

Os cones de crescimento podem ser guiados através de um caminho até o seu alvo por gradientes de substâncias químicas que são secretadas por certas células da sua região alvo [Lasek(1986), Levitan(1997), Hely(1998), Matus(2000) e Van Ooyen(2001)]. Esse fenômeno é conhecido como quimiotropismo e foi proposto inicialmente por Ramón y Cajal [Kandel(1985)], mas verificado experimentalmente apenas em meados de 1979. Os primeiros fatores quimioatratores conhecidos são as famílias do netrinas, presentes no Sistema Nervoso Central, que são relacionados à molécula da laminina. Outro grupo de substâncias são os $B N D F, F G F$ e NT1-5, 
respectivamente, fatores de crescimento derivados do cérebro, fator de crescimento do fibroblasto e família das neurotrofinas [Levitan(1997)]. Além da atração, algumas dessas substâncias também possuem efeito de repulsão. Uma descoberta muito importante é que o neurotransmissor acetilcolina também pode atuar como um quimioatrator difusivo, para influenciar o crescimento do neurito. Esse mecanismo supre uma observação biológica de que, mesmo sem fatores de crescimento, temos a formação de conexão e escolha do alvo.

\section{a.3) Refinamento das Conexões}

As seleções do caminho e das células alvo proporcionam uma conexão altamente específica que pode ser feita na ausência de atividade elétrica neural. Entretanto, uma vez que as conexões ficam eletricamente ativas, é essencial um refinamento nas sinapses de modo a criar uma rede neural funcional. Por exemplo, o refinamento do sistema visual dos mamíferos que ocorre de acordo com a atividade elétrica das conexões [Hely(1998)].

\section{b) Dendritos}

Os dendritos se caracterizam como estruturas altamente ramificadas que são responsáveis por carregar impulsos elétricos das sinapses até o corpo celular. Eles são formados em grande parte pelas actinas, e suas extremidades também possuem cones de crescimento. Desse modo, alguns dos fatores que influenciam o crescimento do axônio também influenciam os dendritos e vice-versa, tais como o campo elétrico e o fenômeno de quimioatratores e repulsores presentes no processo de seleção do alvo. Em especial no começo do desenvolvimento celular, quando ainda não se sabe quem será o axônio ou o dendrito, os fatores de crescimento atuam de forma similar em todas as estruturas.

O movimento dos cones de crescimento presentes nos dendritos (e também nos axônios) é associado à contínua polimerização e despolimerização das actinas nos filopódios, que também é um resultado do gradiente dessas moléculas (moléculas de cálcio) no meio celular. Uma proposta para o mecanismo biológico de polimerização

dessas actinas é apresentado na Seção 2.2.2. Durante o crescimento existem 
moléculas que atuam como ligantes entre o citoesqueleto e o substrato onde se encontra a célula. Se o acoplamento entre eles é fraco, o filopódio pode despolimerizar e voltar a diminuir de tamanho, mas, se o acoplamento for forte, o filamento estaciona e permanece nessa posição, aumentando de volume e criando novos filopódios a partir dessa nova extremidade.

Existem inúmeros modelos biológicos destinados a explicar a evolução das microtubulinas nas células, como podemos verificar em [Mogilner(1996), Molginer(1996)a, Mogilner(1999), Desai(1997)]. Todavia, a evolução e os desenvolvimentos dos microfilamentos na célula (filopódios e dendritos) ainda são pouco explorados na literatura. Além disso, a grande maioria dos modelos existentes destina-se apenas em desenvolver modelos de crescimento desses filamentos, gerando resultados que dizem respeito a velocidade de polimerização e ao tamanho do filamento, e não se interessam em estudar sua interação com a membrana e a forma final da célula. Baseados nessas observações apresentamos a seguir o mecanismo de polimerização da actina, e no Capítulo 3, modelos biológicos de desenvolvimento de filamentos (tubulinas e actinas) do interior celular.

\subsubsection{Mecanismos de Polimerização da Actina}

Os microfilamentos celulares são estruturas constituídas basicamente de actina e constituem a base do citoesqueleto celular. Eles são responsáveis pela forma e pelos movimentos dos pseudópodos da célula. No caso dos neurônios, os pseudópodos compreendem os cones de crescimento e a sua extensão e retração são resultados da polimerização e despolimerização de actinas no filamento.

Apesar do grande interesse ao redor dos cones de crescimento e seus mecanismos, pouco ainda se conhece sobre os mecanismos de polimerização das actinas. Em 1996 Thomas D. Pollard apresentou uma idéia sobre o funcionamento de partes isoladas do crescimento da actina [Mullens(1998)], mas foi somente em 2000 que Pollard propôs um modelo biológico que descreve completamente os mecanismos da polimerização das actinas, denominado modelo de nucleação dendrítica [Pollard(2000)]. O modelo prevê que na ausência de terminações livres os componentes vivem em um estado metaestável. Apesar do grande avanço biológico, modelos computacionais e simulações sobre sua polimerização e o seu 
desenvolvimento ainda são pouco explorados na literatura. Compreender e desenvolver novos modelos, um dos objetivos dessa tese, é um grande desafio atual.

Nos últimos dois anos o complexo Arp2/3 vem sendo visto como o nucleador dos filamentos de actina. Como nucleador entende-se um aglomerado de proteínas que dá início a um novo filamento de actina através da agregação de monômeros livres no interior celular. O complexo Arp2/3 é uma substância estável com sete subunidades, ou seja, 2 actinas relacionadas a proteínas Arp2 e Arp3 e 5 novas proteínas. Inúmeros biólogos vêm utilizando essas estruturas para explicar o início da polimerização do microfilamentos de actina, entretanto o modelo biológico mais aceito continua sendo o proposto por Pollard [Pollard(2000)]. Apesar do modelo incluir várias características e fenômenos do processo, a descrição proposta por Pollard apresenta muitas questões sem respostas. Mesmo assim, ele ainda caracteriza-se como um dos melhores modelos de polimerização das actinas no meio celular. A Figura 3 ilustra todas as etapas do processo de polimerização da actina livre na célula, onde cada número representa um passo específico da polimerização. Nos itens a seguir, descreveremos cada uma das 10 etapas desse processo.

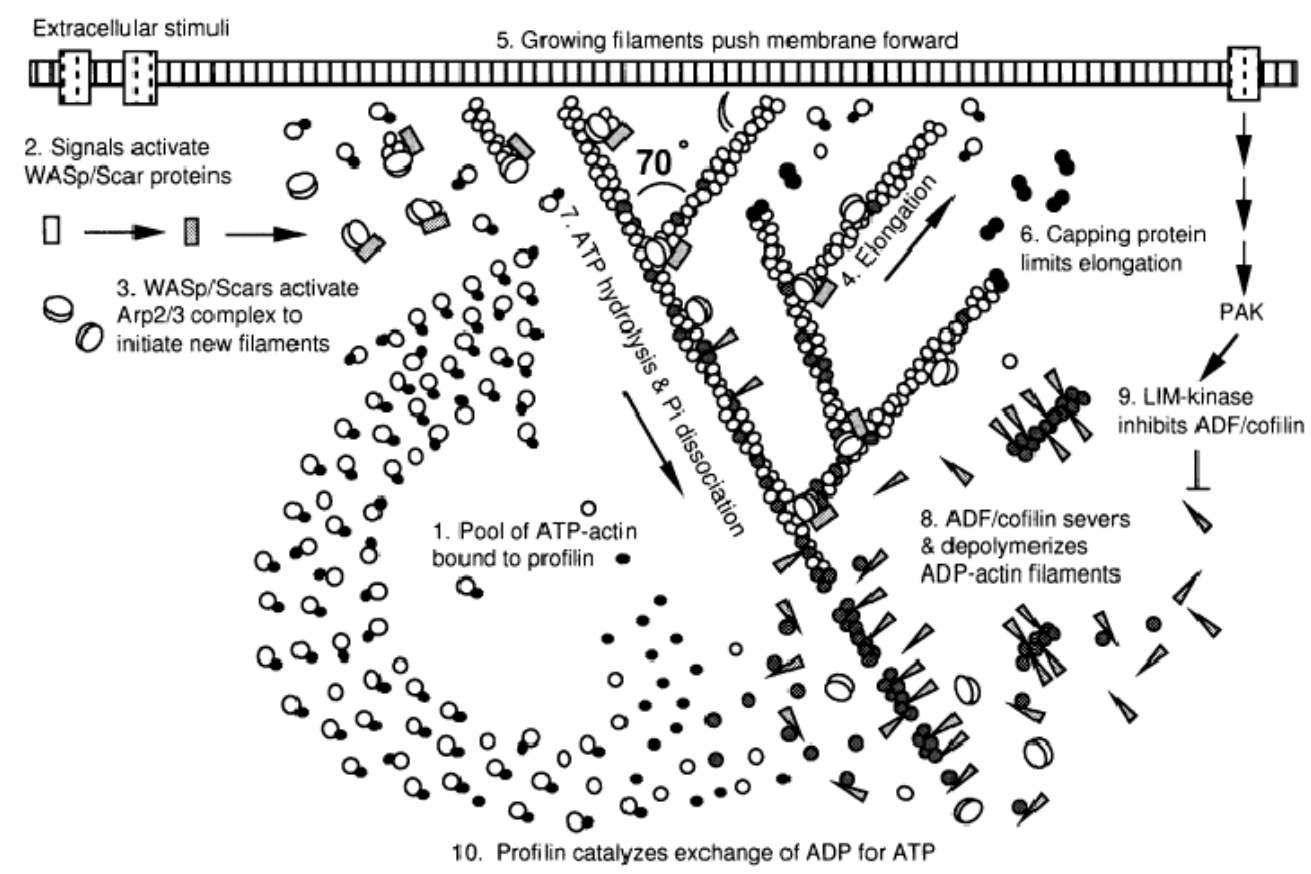

Figura 3 - Esquema proposto em Pollard(2000) para a polimerização da actina no interior celular. 


\section{Processo 1: Conjunto de ATP-Actinas ligadas a Profilina}

O processo de extensão da actina é uma reação bimolecular entre os monômeros de actina e as terminações dos filamentos. Em toda célula existe uma concentração de actinas livres, e elas não se polimerizam mesmo que essa concentração esteja em excesso. Para ocorrer a polimerização existe a necessidade de ocorrer um dos dois fatores descritos a seguir:

- Ocorrência de uma nucleação (iniciação de um novo filamento através da criação dos barbed ends livres) gerada pelo Arp2/3 e por sinais vindos da membrana, o que forneceria a criação de um novo filamento e a sua elongação.

- Ou, a quebra de um filamento já crescido. Se um filamento é quebrado ele fica sem a sua molécula de capping, molécula que termina o filamento e impede que novas moléculas de actina se aglomerem continuando a polimerização.

Embora ambos os fatos podem estar sempre presentes, a ocorrência da quebra de um filamento é muito rara. Desse modo, é usualmente aceito que o início da polimerização de um filamento ocorre unicamente através da sua nucleação.

As actinas livres da célula, denominadas ATP actinas, encontram-se livres ou ligadas à moléculas de profilina ou timosina. Destas, apenas as actinas ligadas a profilina podem se polimerizar, enquanto as actinas livres e as com profilinas contribuem igualmente para o crescimento de um filamento. Desse modo, estando as actinas prontas para crescerem, se tivermos um barbed end livre, a polimerização e a extensão ocorrem em poucos segundos. O barbed end é uma ponta livre no filamento onde podem ser agregadas as moléculas de actina. Ele é formado após a nucleação, ou com a retirada do seu capping, molécula que se encontra fechando as regiões de barbed ends. Sendo assim, se um filamento não tiver o capping na sua ponta ele começa a se elongar. A nucleação é a retirada do capping de uma região de barbed end, iniciando o crescimento de um filamento. A taxa e a extensão de crescimento desses filamentos são limitadas pelo capping e seguem uma reação de primeira ordem. 


\section{Processo 2: Sinais Externos ativam a proteína Wasp/Scar}

O processo da ativação da proteína Arp2/3 através de sinais externos ainda encontrase em discussão. Apesar disso, muitos pesquisadores convergem para a hipótese que a molécula de Wasp/Scar aglomera os estímulos externos e os leva até a Arp2/3 [Machesky(1999), Pollard(2000)]. Acredita-se que a molécula de Wasp/Scar integra diversos sinais externos, inclusive os vindo da família Rho GTPase, Rac e Cdc42 (são proteínas presentes na membrana celular que ativam ou inibem a variação de microtúlos e actinas, de acordo com outras proteínas que se grudam a elas). A quantidade de Wasp/Scar é bem limitada se comparada com a abundância de Arp2/3. Desse modo, a sua ativação é um fator limitante na associação de actinas. O Wasp/Scar fica inativo até que receba um sinal externo de uma das famílias a qual ele responde. Nesse momento, ele se junta ao complexo Arp2/3 e o ativa iniciando o alongamento dos filamentos [Pollard(2000)]. Esse processo é denominado de nucleação.

\section{Processo 3: Wasp/Scar ativa o Arp2/3 e inicia novos filamentos}

A ativação do Arp2/3 iniciará o crescimento do filamento, ou polimerização. Entretanto, antes da descoberta do Arp2/3 nenhuma outra proteína havia mostrado essa atividade. $\mathrm{O}$ filamento de actina em crescimento terá duas pontas, uma delas é denominada barbed end, e a outra, pointed end. Nesta proposta, a agregação de novos monômeros se dá no barbed end livre. De um modo geral, o complexo Arp2/3 altamente purificado nucleia filamentos com barbed ends livres e pointed ends capped (pontas do filamento que não podem receber adição de monômeros). Como resultado, o crescimento do filamento se dá basicamente no barbed end, e acontece de forma extremamente rápida, caracterizando-se por uma reação de difusão.

\section{Processo 4: Alongamento dos filamentos}

O alongamento dos filamentos é a parte mais bem caracterizada do processo, uma vez que é possível investigá-los através de ensaios em laboratório via reação de polimerização. A razão entre a constante da taxa de dissociação e a constante da taxa 
de associação para cada reação nos dá a constante de equilíbrio de dissociação, também conhecida como concentração crítica. A concentração crítica para a $A D P$ actina é a mesma em ambos os lados do filamento. O alongamento das ATP-actinas nos barbed ends é limitado por difusão, isto significa que o inverso da taxa constante é proporcional a viscosidade da solução. No caso especial da viscosidade ser zero, esse valor extrapola para uma taxa constante e infinita.

Dois fatores opostos influenciam as reações de difusão no citoplasma: a alta concentração de macromoléculas que torna a difusão mais lenta de moléculas do tamanho da actina por um fator de 3, e o efeito de exclusão de volume, que aumenta a taxa da reação, incluindo o alongamento do filamento de actina. Assim, a taxa de captura de monômeros em um filamento é dada pela equação mostrada abaixo:

$$
\frac{d n}{d t}=K[\text { actina }]
$$

onde, $n$ é o número de monômeros em um filamento, $K$ a taxa constante (que é proporcional ao inverso da viscosidade) e [actina] é a concentração de actina livre na célula. De acordo com ensaios de laboratório, o valor amplamente aceito para a variação dos monômeros no filamento de actina é da ordem de 800 monômeros/s.

O filamento de actina pode apresentar ramificações, como pode ser visto na Figura 3. Porém, pouco ainda se conhece sobre o mecanismo de ramificação presentes no microfilamento. A dúvida consiste em descobrir se as moléculas de nucleação são agregadas ao filamento, e a partir daí começam a crescer ramificações, ou ainda se um filamento já crescido se gruda a outro filamento através da sua molécula de nucleação. Além do crescimento rápido sabe-se que as ramificações possuem um ângulo fixo de crescimento em relação aos filamentos, ou seja, as ramificações sempre possuem ângulo de $70^{\circ}$ em relação a outro filamento [Mullens(1998)]. Desse modo, o ângulo entre a ramificação e a membrana será sempre de $55^{\circ}$.

Apresentamos na Figura 4 uma ilustração mais específica sobre as ramificações e os filamentos, incluindo a informação sobre os ângulos entre um filamento e outro, e o ângulo entre as ramificações e a membrana. Na Figura 5 apresentamos algumas micrografias com as estruturas dessas ramificações [Mullens(1998)]. No item (a) 
temos as actinas livres e as moléculas de Arp2/3, enquanto nas Figuras 5(b-d) apresentamos imagens dos filamentos de actina e de suas ramificações.

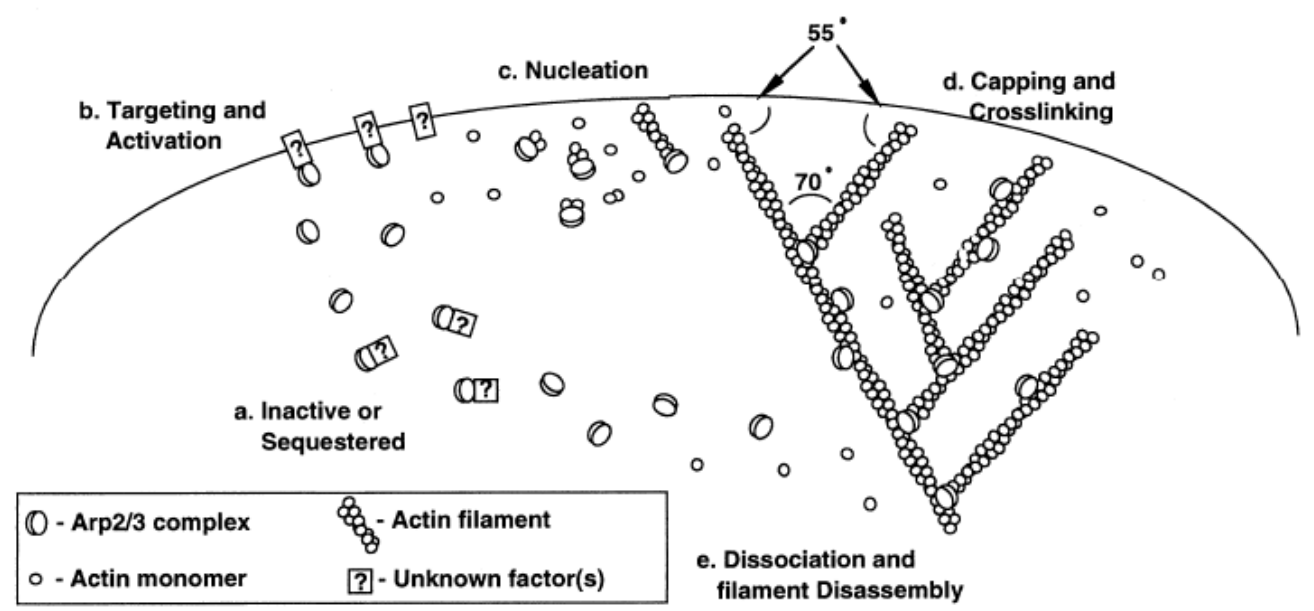

Figura 4 - Ilustração do ângulo de crescimento das actinas na célula [Mullens(1998)].
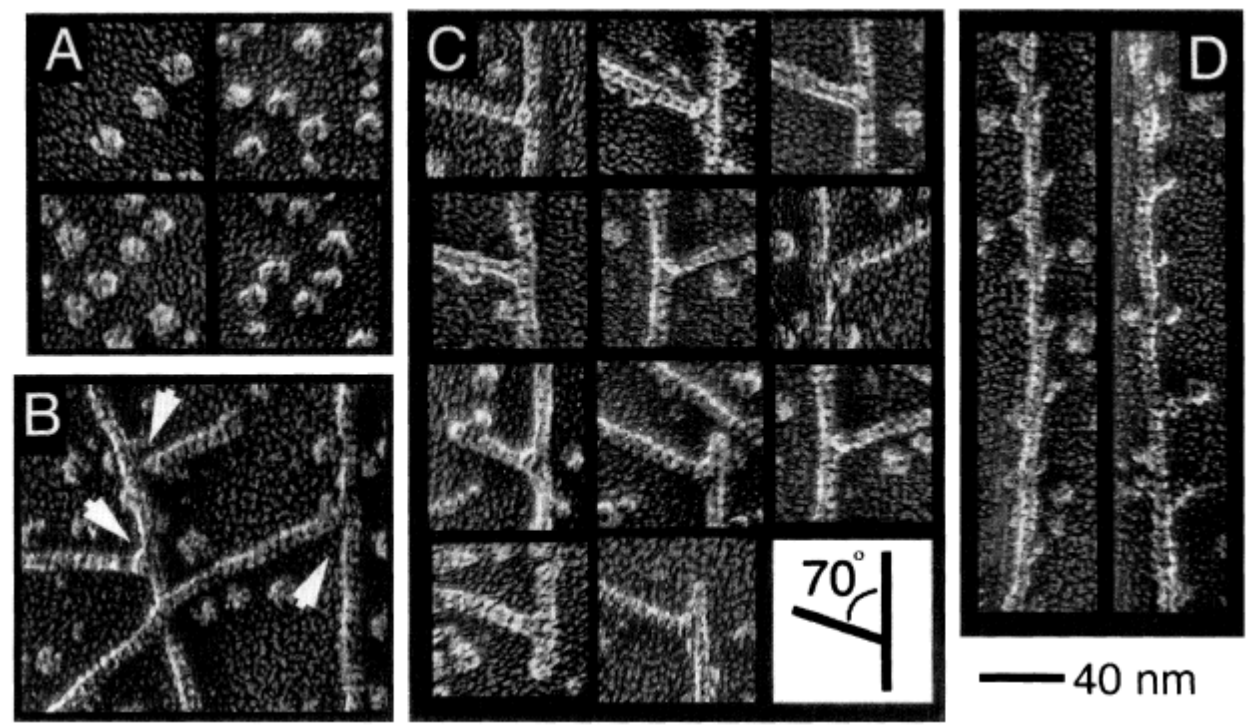

Figura 5 - Imagem de microscopia dos ângulo entre as ramificações nos filamentos de actina [Mullens(1998)].

\section{Processo 5: Crescimento dos Filamentos empurrando a Membrana}

A rede de filamentos de actina é adaptada para transformar a energia livre convertida da união dos monômeros em energia mecânica. A idéia da polimerização, por si só, gera uma força que deforma a membrana. 


\section{Processo 6: Capping nos Filamentos}

O controle da polimerização da actina se dá nos barbed ends dos filamentos, ou seja, para criar novos filamentos as células criam novos barbed ends. Desse modo, para limitar o crescimento, a solução é colocar uma molécula de capping nos barbed ends, ou seja, colocar uma molécula que limita esse crescimento e "fecha" o filamento. Esse capping é feito pela proteína denominada CapZ. O capping gruda fortemente nos barbed ends do filamento de actina, a sua constante da taxa de associação é de $3 \mu \mathrm{ms}^{-1}$.

Devido a alta concentração de proteínas de capping, o tempo de vida médio de um barbed ends é de aproximadamente 0,25 s. Apesar do tempo de vida médio ser curto, o segmento consegue agrupar por volta de 200 monômeros, devido a alta concentração de actinas livres.

A alta afinidade das proteínas de capping pelos barbed ends resulta em uma taxa de dissociação extremamente lenta $5 \times 10^{-4} s^{-1}$, e o tempo médio de vida para o filamento fazer o uncapping é $1000 \mathrm{~s}$, muito maior que o tempo de dinâmica das células. Logo, uma vez formados e com capping, um filamento não volta a crescer.

\section{Processo 7: Hidrólise do ATP e Dissociação do Fosfato}

Uma vez que as moléculas de ATP unidas a actina encontram-se nos filamentos, pode ocorrer a dissociação do fosfato do ATP, marcando a célula para a despolimerização. Esse processo se dá através da molécula de ADF/Cofilina e serve como um marcador (timer) para a destruição do filamento. A hidrólise do ATP e a dissociação do fosfato são ambas reações de primeira ordem. O modelo mais simples adotado para essas reações é obtido tomando-se cada unidade do polímero atuando independentemente, ou seja, existe a mesma probabilidade de hidrolização do ATP e da dissociação do fosfato.

\section{Processo 8: Despolimerização}

Existem movimentos muito rápidos durante a extensão de pseudópodos na célula, e a despolimerização deveria ter a capacidade para poder simular esses movimentos. Se 
considerássemos apenas uma região específica da célula, a taxa de despolimerização seria muito alta. Entretanto, a situação é ainda mais complicada pois dá ao longo de uma faixa larga da célula. Entende-se que a despolimerização é restrita apenas as terminações dos filamentos, e que a taxa de despolimerização depende diretamente da taxa de dissociação das subunidades de actina $(k-)$ e da concentração de barbed ends livres, menos a taxa de associação da subunidade. A taxa de dissociação nos barbed ends é de $7 s^{-1}$, e de $0,3 s^{-1}$ nos pointed ends. Dentro desse contexto, para uma determinada massa de polímero, a concentração de barbed ends livres é inversamente proporcional ao comprimento dos filamentos. Logo a taxa de despolimerização de volume é inversamente proporcional ao comprimento do polímero. Por isso, o fenômeno de severing (quebrar o filamento em pedaços) é tão importante na despolimerização. De modo geral, a ADF/Cofilina promove a despolimerização, pois ela quebra o filamento de actina e cria mais barbed ends livres, aumentando assim a taxa de dissociação da subunidade para um ou mais ends. A despolimerização começa quando a $\mathrm{ADF} / \mathrm{Cofilina}$ corta o filamento entre os cappings, ou retira-os do filamento.

Nesse ponto surge uma dúvida muito interessante sobre os filamentos, o porquê dos cappings da solução não fecharem esses filamentos livres. Acredita-se que esse fenômeno não acontece porque a ligação é muito lenta.

\section{Processo 9: LIM/Kinase inibe a ADF/Cofilina}

Ao mesmo tempo em que acontece a ativação da despolimerização pela ADF/Cofilina, é ativado um outro mecanismo que regula a estabilidade das actinas, o LIN/Kinase. O que essa proteína faz é reduzir a afinidade da ADF/Cofilina com os monômeros de actina e filamentos.

\section{Processo 10: Mudança do ADP para $A T P$ usando a Profilina}

Conseqüentemente, teremos na célula a actina ADP livre ou a ADF/Cofilina como resultado da despolimerização. Entretanto, a profilina compete com a ADF/Cofilina para se ligar a actina ADP e dissociá-la. Esse processo funciona porque ambas as reações são rápidas, logo a profilina se junta ao $\mathrm{ADP}$ e a dissocia rapidamente, 
gerando o ATP e repondo o estoque de actinas prontas para a polimerização na célula (processo 1). Além disso, deixa livre a molécula de $\mathrm{ADF} /$ profilina para atuar novamente no processo de despolimerização.

A partir das considerações biológicas apresentadas nos 10 processos anteriores, apresentamos no Capítulo 6 um modelo de crescimento do neurônio baseados em todos esses processos através de forças restauradoras (sistema massamola). O modelo também leva em consideração a evolução da membrana de acordo com deslocamentos localizados, como os do filamento de actina. O processo biológico de geração de actinas e microtúbulos envolvidos durante o desenvolvimento da célula neural é muito complexo, e ainda inclui diversos pontos obscuros. Entretanto, recentemente muitos pesquisadores vêm se dedicando a pesquisas que visam elucidar muitos desses processos biológicos, o que possibilitará a geração de modelos computacionais mais próximos da realidade biológica. 


\section{CAPÍTULO 3: MODELOS NEURAIS COMPUTACIONAIS}

Neste Capítulo apresentaremos uma breve revisão sobre os modelos neurais computacionais disponíveis na literatura. Foram abordadas suas principais características, incluindo, especialmente, quais os tipos de simulação a serem realizadas, sejam elas de dados eletrofisiológicos, ou de modelos de crescimento neural. Essa revisão bibliográfica é de grande importância ao trabalho, pois permitiu o conhecimento dos modelos desenvolvidos até o momento e qual tipo de tratamento é realizado para cada estrutura ou hipótese biológica. Essas informações serviram como base para o desenvolvimento de modelos de crescimento de neurônio apresentados no Capítulo 6, possibilitando o acréscimo de dados realmente relevantes ao problema, uma vez que os modelos descrevem essas características biológicas, o modo como elas atuam na célula e a importância delas no desenvolvimento celular.

De acordo com suas abordagens, os modelos neurais foram separados em dois grandes grupos, são eles: $(i)$ modelos funcionais, preocupados em formular esquemas que representem as funções dos neurônios (impulsos nervosos), sem buscar uma maior realidade quanto à forma, e (ii) os de crescimento neural, que simulam o desenvolvimento do neurônio dando grande importância a sua forma e aos padrões que influenciam no crescimento. Além disso, neste Capítulo também apresentamos a implementação de um dos modelos de crescimento neural mais completos da literatura. Ele foi desenvolvido por Samuels, Hentschel e Fine [Hentschel(1994) e Samuels(1996)] e sua principal característica é a inclusão de um grande número de características biológicas, tais como a ação do cálcio como agente morfogênico, a membrana eletricamente ativa, as bombas de $\mathrm{Na}^{+}, \mathrm{Ca}^{+}$, e $\mathrm{K}^{+}$, dentre outras. 


\subsection{Modelos Funcionais}

A seguir, apresentamos uma descrição dos principais modelos funcionais que simulam a emergência de estruturas no córtex visual, e os modelos de simulação de potencial de ação e respostas eletrofisiológicas dos neurônios. Eles são conhecidos por, respectivamente, modelo de Hodgkin-Huxley [Shepherd(1986)] e por modelo Compartimental [Kandel(1985)e Koch(1989)].

\subsubsection{Modelos do Córtex Visual}

Dentre os modelos funcionais, devemos destacar os interessados na simulação de estruturas que emergem no córtex visual de primatas. Eles resultam da resposta do neurônio a uma determinada orientação do estímulo e a um determinado olho que são, respectivamente, as colunas de orientação e a dominância ocular [Kandel(1985), Dowling(1992) e Hubel(1995)]. Elas são formações encontradas nos neurônios do córtex resultantes de estímulos visuais e incluem desde modelos simples, que utilizam apenas proposições biológicas (Hubel e Wiesel) e modelos baseados em filtros (Roger e Schwartz), até modelos mais sofisticados envolvendo redes neurais (Von der Malsburg) [Swindale(1996)]. Nestes casos, desenvolvem-se regras de crescimento das sinapses baseados em interações com as células da vizinhança e na sua atividade celular [Swindale(1996)].

Existem ainda outros modelos de redes neurais, [Swindale(1996), Sandberg(2003)], que simulam as interações entre os neurônios através de regras de crescimento de conexões neurais, denominadas regras hebbianas. O objetivo principal é obter a resposta do neurônio a partir de um estímulo (imagem) inicial. As conexões são refinadas através de treinamentos gerados na rede neural, de modo que ela possa determinar posteriormente os estímulos a serem apresentados. As inspirações iniciais das redes neurais são células biológicas, e muitas das técnicas incluem características biológicas dentro do modelo. Todavia, devemos ressaltar que os modelos de crescimento de neurônio também fazem uso das teorias de dominância ocular, de colunas de orientação e de redes neurais, uma vez que após a simulação do desenvolvimento do neurônio inicia-se uma fase de análise do seu comportamento, onde é investigado se os neurônios gerados são capazes de apresentar a emergência 
dos padrões de dominância ocular e das colunas de orientação, ou apresentar a resposta correta para um determinado estímulo.

\subsubsection{Modelo de Hodgkin-Huxley}

A natureza elétrica do impulso nervoso e a sua velocidade limitada foram descobertas importantes para o campo da fisiologia, pois foram as primeiras evidências desse tipo de atividade no cérebro [Sheperd(1994)]. No entanto, ficou provado que esse mecanismo envolvia mais do que simplesmente eletricidade passando ao longo de um fio (no caso, o axônio). Ele também envolvia um processo biológico ativo, que passou a ser denominado potencial de ação [Kandel(1985) e Sheperd(1994)]. Nesse mesmo momento começaram a aparecer modelos que se destinavam à simulação do potencial elétrico dessa membrana celular. Esse potencial gerado na membrana do neurônio é referente à diferença de potencial entre o interior e o exterior da célula, que separa duas soluções aquosas de diferentes concentrações de íons. Na parte interna temos íons de sódio $\left(\mathrm{Na}^{+}\right)$e cloro $\left(\mathrm{Cl}^{-}\right)$em concentrações, respectivamente, 10 e 14 vezes menor que o exterior. Já o íon de potássio possui uma concentração 30 vezes maior no interior que no exterior. Na situação de repouso, os íons estão em permanente movimento através da membrana, como forma de anular a distribuição desigual. Os íons de $\mathrm{K}^{+} \mathrm{e} \mathrm{Cl}^{-}$se movem mais rapidamente que os de $\mathrm{Na}^{+}$, pois os seus gradientes de concentrações são maiores, gerando permeabilidades diferentes para os vários íons, onde seus potenciais são definidos através da equação de Nernst [Kandel(1985), Sheperd(1994)]. O potencial total da membrana é resultado da combinação dos potenciais dos diversos íons, e sua equação é denominada de equação de campo-constante [Sheperd(1994)]. O potencial de equilíbrio descreve o comportamento do potencial em uma membrana celular em repouso. Quando modificamos rapidamente a carga do interior da célula, a membrana da célula (na região do axônio) responde através de uma mudança rápida no seu potencial, o que denominamos potencial de ação e consiste na despolarização transiente do potencial da membrana através da abertura e fechamento dos canais de sódio e potássio [Kandel(1985) e Sheperd(1994)]. Nesse caso, como o modelo concentra-se em explicar o comportamento elétrico da célula neural, uma maneira utilizada para representar a membrana é descrevê-la através de um circuito elétrico, onde cada 
potencial de equilíbrio $\left(\mathrm{K}^{+}, \mathrm{Na}^{+}, \mathrm{Cl}^{-}\right)$equivale a uma bateria em série com as resistências representando as permeabilidades dos íons na membrana. Assim, o modelo de Hodgkin-Huxley determina a variação da corrente iônica ao longo do axônio e a condutância do $\mathrm{Na}^{+}$e $\mathrm{K}^{+}$, através da aplicação da lei de $\mathrm{Ohm}$ aos circuitos representados na membrana. Baseados nos dados experimentais, o modelo é capaz de descrever as equações para as variáveis que controlam as condutâncias, e com elas reproduzir o potencial de ação.

\subsubsection{Modelo Compartimental}

Em meados de 1950, foi desenvolvida a teoria para a interpretação dos dados experimentais obtidos por neurônios individuais através dos microeletrodos intracelulares [Kandel(1985) e Koch(1989)]. Nesta teoria, os axônios e os dendritos são tratados como tubos finos, geralmente idealizados como cilindros condutores e com corrente elétrica fluindo paralelamente ao eixo do cilindro. A formulação matemática da variação da tensão ao longo da membrana celular resulta na Equação do Cabo [Kandel(1985) e Koch(1989)]. O modelo compartimental caracteriza-se como uma extensão da teoria do Cabo para árvores dendríticas, possibilitando construir modelos mais realistas morfologica e fisiologicamente, descrevendo o fluxo da corrente usando equações diferenciais parciais.

Em princípio o modelo Compartimental consegue tratar tanto casos simples, quanto complexos, pois transforma as equações diferenciais contínuas do modelo analítico em um conjunto de equações diferenciais ordinárias [Koch(1989)]. O modelo assume que o sistema é dividido em pequenos pedaços suficientemente pequenos (compartimentos), de modo que o erro seja desprezível se assumirmos que cada compartimento é uma isopotencial e está espacialmente uniforme em suas propriedades. Assim, as não uniformidades físicas e as diferenças nos potenciais ocorrerão entre os compartimentos. Como resultado, cada segmento é representado por um circuito equivalente, onde cada compartimento é conectado ao seu vizinho através de resistores em série que representam o citoplasma. A vantagem da utilização do modelo compartimental é que ele não impõe nenhum tipo de restrição nas propriedades da membrana de cada compartimento. Elas podem ser de dendritos ou axônios, estarem passivas ou excitadas, podem conter uma variedade de entradas 
sinápticas, possuírem ramificações dendríticas ou axonais complexas, e outros tipos de irregularidades morfológicas, permitindo uma grande flexibilidade às soluções. Apesar do modelo incluir informações referentes à morfologia da forma neural, ele ainda caracteriza-se como uma aproximação da realidade, pois a forma neural é representada por uma combinação de resistores e não por suas estruturas biológicas físicas.

\subsection{Modelos de Crescimento}

Os modelos funcionais conseguem descrever, com grande precisão, as características elétricas do neurônio, mas nenhum deles possui uma preocupação muito grande quanto as suas descrições morfológicas. Como já comentado, a diversidade das formas neurais encontradas pelos neurobiologistas leva-nos a acreditar que essa variedade é importante para o cérebro, e deve estar relacionada diretamente à função do neurônio, fato que é amplamente defendido por alguns pesquisadores [Purves(1988), Lasek(1986), Evans(1989), Purves(1990), $\quad$ Costa(1997), Coelho(2002)]. Esse tipo de questionamento iniciou uma nova tendência nos modelos neurais, os modelos de desenvolvimento neural, cuja abordagem pode ser vista em alguns trabalhos recentes [Coelho(1998), Hely(1998), Hentschel(1999), Coelho(2002)], sendo também um dos objetivos dessa tese. Concomitantemente, muitos biólogos e neurocientistas também vêem dando grande atenção ao crescimento de células neurais [Banker(1991), Stirling(1995) e Levitan(1997)] e a sua plasticidade no cérebro [Kornack(2001)].

No caso dos modelos de desenvolvimento neural, as simulações estão interessadas na forma final do neurônio durante a presença de agentes que simulem a sua interação com o meio. Nessa linha de pesquisa, o resultado biológico do crescimento de neurônios já vem sem sendo desenvolvido há algum tempo por pesquisadores, e muito já se conhece sobre estruturas de crescimentos e as substâncias que facilitam ou inibem o crescimento. Um dos principais pesquisadores a realizar esse tipo de cultura em laboratório foi Gary Banker [Banker(1991)], cujo trabalho, em desenvolvimento, têm proporcionado o aperfeiçoando de técnicas, de substratos, e da ação de fatores de crescimento. 
Além de Gary Banker, existem outros pesquisadores trabalhando com crescimento de neurônios baseando-se no crescimento de axônios e na dinâmica dos cones de crescimento [Stirling(1995) e Levitan(1997)]. Além disso, existe atualmente um grande interesse na construção de interfaces biônicas, que vem gerando pesquisas na área de crescimento de neurônio sobre pastilhas de silício [Fromherz(1994)], inclusive no Brasil [Pinto(2001)b], e neurotransistores [Fromherz(1995)]. Entretanto, pouco ainda se conhece sobre o comportamento do desenvolvimento do neurônio, ou sobre modelos que simulem o seu crescimento. A seguir, apresentamos os principais modelos de estruturas neurais ou de crescimento de células neurais que se encontram intimamente relacionados a sua forma e que nos motivaram à realização desse trabalho.

\subsubsection{Morfogênese de Turing}

Historicamente, Alan Turing em [Turing(1952)] propôs o primeiro modelo de morfogênese, conhecido como modelo de reação-difusão (reaction-diffusion model). O modelo prevê a emergência de padrões quando duas ou mais substâncias químicas se difundem e interagem. Uma das substâncias atua como inibidor $(B)$ e a outra como ativador $(A)$ das reações, nelas próprias e na outra. A inclusão do processo de difusão resulta na variação das substâncias $A$ e $B$ dadas pela Equação (1).

$$
\frac{\delta A}{\delta t}=D_{A} \nabla^{2} A+k_{1} A-k_{2} B \quad \frac{\delta B}{\delta t}=D_{B} \nabla^{2} B+k_{3} B-k_{4} A
$$

onde $D_{A}$ e $D_{B}$ são as constantes de difusão e $k_{1}, k_{2}, k_{3} e k_{4}$ são constantes da equação. Para ocorrer a formação de um padrão pelo sistema de Turing, é essencial que o ativador $A$ tenha uma difusão mais lenta que o inibidor $B$. Sob certas condições dos parâmetros, e das taxas de difusão, podemos ter uma aceleração no tamanho das perturbações e obtemos a emergência dos processos desejados. Uma de suas vantagens é a capacidade de gerar um grande número de padrões diferentes capazes de simular diversos tipos de padrões de crescimento. As Figuras 6(a) e (b) apresentam alguns exemplos de sistemas de reação-difusão [Prusinkiewicz(1997)]. Em (a) temos um exemplo de uma variação do modelo de reação de difusão proposto 
por Young [Young(1984)], onde as áreas de maior concentração (em amarelo) se agregam conforme o tempo evolui, produzindo padrões de manchas claras sobre o fundo preto. No item (b) temos uma variação do modelo de reação-difusão proposta por Gierer and Meinhardt [Gierer(1972)] para a produção de padrões de cores em conchas do mar.

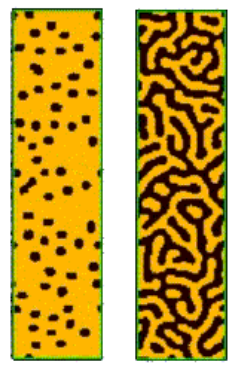

(a)

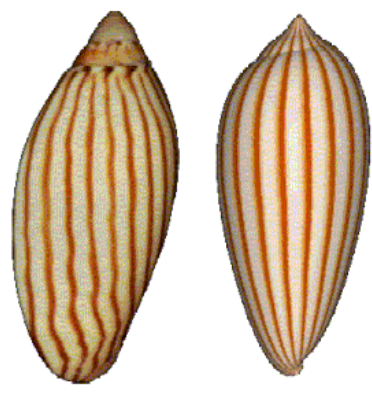

(b)

Figura 6 - Padrões obtidos de sistema de reação-difusão [Prusinkiewicz(1997)].

\subsubsection{Modelos Relacionados a Dinâmica dos Microtúbulos e Cones de Crescimento}

A partir das idéias desenvolvidas por Turing, cresceu o interesse em modelos teóricos provenientes de dados biológicos, mas foi apenas em 1984, em um artigo de Mitchison e Kirschner [Mitchison(1984)] sobre as instabilidade na dinâmica dos microtúbulos, que começaram a surgir modelos teóricos que viessem explicar o comportamento de crescimento dos microtúbulos. A importância dos microtúbulos deve-se ao fato dele ser um dos responsáveis pelo crescimento ou retração das ramificações neurais, dando suporte estrutural ao axônio [Lasek(1986), e Levitan(1997)].

Em 1984, Hill e Chen, Hill(1984), construíram o primeiro modelo teórico para explicar a dinâmica dos microtúbulos. Eles usaram simulações cinéticas de MonteCarlo para mostrar dinamicamente como as fases de instabilidade dinâmica do crescimento/retração poderiam acontecer na extremidade dos microtúbulos, devido à ação de um polímero. Inicialmente foi realizada a modelagem do polímero em equilíbrio, para depois estender a análise e incorporar a dinâmica de crescimento/retração dos microtúbulos. O modelo de equilíbrio simula o crescimento/retração no comprimento do microtúbulo através de uma unidade de 
tubulina. $\mathrm{O}$ estado atual é representado por $P_{0}$, e o estado futuro, de crescimento $\left(P_{C}\right)$ ou retração $\left(P_{R}\right)$, dependerá da razão entre as concentrações de tubulinas livres $(\lambda)$, e a de tubulinas agrupadas ( $\left.\lambda^{\prime}\right)$ e do estado de equilíbrio, conforme a Eq.(2).

$$
P_{C}=\left(\lambda / \lambda^{\prime}\right) P_{0} \quad P_{R}=\left(\lambda / \lambda^{\prime}\right) P_{C}=\left(\lambda / \lambda^{\prime}\right)^{2} P_{0}
$$

O crescimento do microtúbulo se dará quando $\lambda>\lambda$ ' e a sua retração quando $\lambda<$ $\lambda$ '. No caso das duas concentrações serem iguais o polímero é estático. Quando temos o crescimento ou retração de um microtúbulo, existe uma molécula que barra o seu processo, denominada cap, que é a unidade $T$ (monômero ligado ao GTP, ou $T$ GTP). Durante o crescimento, adiciona-se mais de uma unidades de T-GTP ao microtúbulo que já encontra-se fechado por ela, a hipótese é que se o T-GTP for perdido por algum motivo externo, o polímero rapidamente encolhe até que encontre uma outra unidade de T-GTP. O modelo foi estendido de tal modo que a situação de equilíbrio incluiu taxas constantes para a transição entre as fases de crescimento e a de retração [Chen(1985)]. Esse modelo ficou conhecido como modelo GTP-Cap e os resultados encontrados pelas suas simulações concordaram com resultados biológicos obtidos in vitro e com os resultados anteriores de Mitchison e Kirschner [Mitchison(1984)].

Apesar dos bons resultados, o modelo se mostrou insatisfatório para alguns casos como, por exemplo, a falha na detecção experimental do cap do T-GTP. Dentro desse contexto, em 1990, Bayley, Schilstra, e Martin [Bayley(1990)], aperfeiçoaram o modelo criando o Lateral Cap. No modelo Lateral Cap a ponta do microtúbulo é simulada através de um reticulado com 13 filamentos (dímeros de tubulina), e a adição ou perda dessas subunidades ocorre à uma taxa constante e depende da ação do $G T P / G D P$ e de seus vizinhos. Para cada unidade existem pelo menos 4 vizinhos que influenciam de acordo com o seu estado GTP ou GDP. O modelo é capaz de simular a mudança individual dos microtúbulos entre crescer ou diminuir em termos de experimentos validados feitos com a extremidade do microtúbulo. O GTP Cap e o Lateral Cap são modelos que simulam a adição ou perda de uma estrutura individual na extremidade do microtúbulo e podem mostrar como as instabilidades dinâmicas dos microtúbulos podem emergir. 
Em 1994, Holy e Leibler [Holy(1994)] propuseram um modelo mais simplificado para a dinâmica do microtúbulo baseado em 4 parâmetros globais, são eles: velocidade de crescimento e de retração, freqüência de catástrofe (mudança do estado de crescimento para a retração) e de resgate (mudança do estado de retração para o crescimento). A sua diferença é não utilizar a concentração dos monômeros, da tubulina, ou das probabilidades de adição e subtração das tubulinas, pois esses valores ficam implícitos nos parâmetros escolhidos. O modelo foi utilizado para análise da formação do fuso mitótico celular, pois durante a mitose os microtúbulos nucleiam no centrossomo e se estendem radialmente.

Apesar dos microtúbulos estarem intimamente ligados ao desenvolvimento da célula neural, podemos notar que os modelos da sua dinâmica celular descritos até o momento não incluirem a formação de axônios ou ramificações Apenas alguns pesquisadores se interessavam pela geração de ramificações e sua ligação com os microtúbulos. Porém, em 1988, Buxbaum e Heidemann [Buxbaum(1988)], desenvolveram um modelo termodinâmico para elongação dos neuritos, posteriormente melhorado em 1992. Em ambos os modelos, a elongação é descrita em termos da tensão exercida no substrato pelo neurito em crescimento. Assume-se que a taxa de crescimento do axônio é a mesma da associação do microtúbulo, mas ignora-se o efeito da instabilidade. No primeiro modelo de 1998, Buxbaum e Heidemann definem a tensão mecânica do axônio sobre o substrato como a soma de três termos, a força externa na actina, a força externa nos microtúbulos e a energia de associação dos microtúbulos, mais a interação com a superfície. Na reformulação do modelo, em 1992, eles assumiram que parte da força envolvida no movimento de crescimento dos cones vem da compressão dos microtúbulos associados. Os resultados encontrados para o crescimento do axônio sob a ação de forças externas foram semelhantes aos obtidos em laboratório.

Em 1998, Tim Hely também apresentou alguns trabalhos onde descrevia a simulação da dinâmica de microtúbulos no cone de crescimento [Hely(1998)a]. No seu primeiro modelo ele simula o efeito do empacotamento dos microtúbulos na taxa de elongação do axônio, mostrando que os efeitos de pequenas interações em microtúbulos individuais podem ser amplificados pelo 'pacote' de microtúbulos e aumentam significantemente a taxa de elongação do axônio. Já o segundo modelo simula o efeito de dilatação dos microtúbulos, descoberto por Tanaka e Kirschner 
[Tanaka(1991)], e a invasão rápida dos microtúbulos no cone de crescimento da célula alvo, fazendo o contato. Isso suporta a idéia de que o seu caminho não é aleatório, mas segue uma direção pré-determinada, sugerindo assim que eles dependam de interações com outros microtúbulos e com a F-Actina. O modelo simula ainda a dinâmica dos microtúbulos usando as 4 propriedades propostas por Holy e Leibler [Holy(1994)], estendem-no de modo que inclua as interações entre os próprios microtúbulos com a F-Actina. Neste contexto, supondo que existam aproximadamente 40 microtúbulos no feixe do neurito, as interações entre os microtúbulos sugerem que a dinâmica de 1 e de 20 microtúbulos geram reações diferentes, fato que pode ocasionar uma barreira contra a entrada da F-Actina, e também tornar as estruturas mais estáveis diminuindo a freqüência de encolhimento. Desse modo teremos velocidades de crescimento/encolhimento diferentes para os microtúbulos isolados e para os agrupados.

\subsubsection{Modelos Relacionados à Dinâmica do Filopódio}

Apesar dos bons resultados encontrados, os modelos apresentados no item anterior se concentram apenas na dinâmica dos microtúbulos, que são importantes na elongação do axônio e na mudança de direção do cone de crescimento. Mas, existem também os modelos que estão interessados na dinâmica do filopódios, estruturas finas e longas que são criadas na extremidade da membrana do cone de crescimento atuando como antenas, capazes de traduzir sinais do meio externo, como por exemplo canais de adesão e gradientes de neurotrofinas [Lasek(1986), Levitan(1997), Hely(1998)]. Eles são capazes de convertê-los em sinais que alteram a estabilidade das actinas e da rede de microtúbulos. Sabe-se que os filopódios são essenciais durante a navegação dos cones de crescimento e existem diversos estudos sobre quais são os fatores que regem essa modificação.

Alguns trabalhos experimentais realizados por Davenport e Kater [Davenport(1992)] mostraram que essa movimentação está ligada a concentração de cálcio, e que o cálcio que entra na célula está ligado ao crescimento do filopódio [Davenport(1996)]. Além disso, esse mesmo cálcio é proposto como um regulador de forma dendrítica no modelo computacional desenvolvido por Hentschel em 1994 [Hentschel(1994)], que será descrito na Seção 3.2.5. 
A partir da idéia do cálcio como agente morfogênico, Hely propôs em 1998 um modelo de dinâmica de filopódios baseado no sistema de equações reação-difusão propostos por Alan Turing, Eq. (1). O propósito das simulações é utilizar o sistema de equações usando o cálcio como um agente ativador, $A$, e o $c A M P$ como um agente inibidor, B, cAMP são mensageiros secundários das células e são responsáveis por inibir o crescimento celular, produzindo padrões espaciais e temporais que podem simular o efeito de extensão e retração do filopódio [Hely(1998)]. O cálcio atua sobre si mesmo e no $c A M P$ com taxas constantes de $k_{1}$ e $k_{3}$. Uma diminuição nos níveis de cálcio levam ao CIRC (cálcio induzido cálcio liberado, ou seja a liberação de cálcio induzida) que diminuem os níveis de $c A M P$, inibindo posteriores aumentos no cálcio.

O crescimento é restrito a um número definido de pixels que representam os sítios do filopódio na membrana externa. Cada um dos pixels do filopódio contém um ponto que é representado por uma coordenada $(x, y)$ na extremidade do filopódio. O movimento de cada pixel depende diretamente da concentração de cálcio e é calculado usando a Eq. (3).

$$
\text { Crescimento }=h\left(e^{k\left(C a-C a_{\text {peak }}\right)^{2}}-\text { offset }\right)
$$

onde $C a_{\text {peak }}$ é o máximo da concentração de cálcio permitida, $h$ é a máxima velocidade de crescimento, $k$ controla a largura da curva, e offset indica onde ocorre o cruzamento por zero na curva de crescimento.

\subsubsection{Modelos de Ramificações Dendríticas}

Além dos modelos de formação do axônio e filopódios, podemos apresentar alguns exemplos de modelos de ramificações dendríticas, os quais podem ser divididos em duas categorias: os modelos estatísticos (data driven) e os baseados em processos de ramificação (process driven). 


\section{(a.1) Modelos Estatísticos}

Os modelos estatísticos simulam um padrão de ramificação particular do neurônio sem utilizar considerações sobre a forma biológica do citoesqueleto. Em geral eles utilizam um número limitado de parâmetros para caracterizar estatisticamente a árvore dendrítica envolvida. Existem dois modelos mais conhecidos desse tipo, são eles: o $Q S$, e uma recente extensão o BESTL, cujos significados serão explicados a seguir. Seus principais argumentos baseiam-se em um mecanismo de ramificação aleatória que é suficiente para gerar uma grande variedade de ramificações e de padrões geométricos vistos em árvores dendríticas biológicas.

O modelo $Q S$ foi desenvolvido por van de Pelt e Verwer [Van Pelt(1986)] e caracteriza-se como um dos primeiros a conseguir caracterizar diferentes tipos de ramificações dendríticas. Ele é baseado em segmentos intermediários (segmento anterior a uma ramificação) e segmentos finais (segmento sem ramificação). $O$ modelo simula o processo de ramificação em tempos discretos, e a cada tempo existe a escolha aleatória de se criar um segmento intermediário ou um final. O processo é repetido até que se construa uma árvore dendrítica. Os parâmetros $Q$ e $S$ são utilizados para determinar a probabilidade que um dado segmento tem de ser intermediário $(Q)$, ou final $(S)$, no próximo instante de tempo.

Alguns dados biológicos indicam que a probabilidade de ramificação diminui, conforme o número de pontos de ramificação que cai entre um dado segmento e o soma aumentam (ordem centrífuga $=\gamma$ ). O parâmetro $S$ determina o efeito da ordem centrífuga na probabilidade de ramificação no segmento terminal e é dado pela Eq. (4), onde C é a constante de normalização, de tal modo que a soma das probabilidades de ramificação sejam iguais a 1 .

$$
P_{\text {ter } \min a l}=C 2^{-S \gamma}
$$

Se $S=0$ todos os segmentos terminais tem a mesma probabilidade de ramificação e se $S=1$, a probabilidade das ramificações terminais caem por 2 com cada aumento na ordem centrífuga $\gamma$. O parâmetro $Q$ determina o alcance pelo qual o segmento intermediário se ramifica, e sua probabilidade é expressa pela Eq. (5). 


$$
P_{\text {int ermediário }}=\frac{Q}{1-Q} P_{\text {ter min al }}
$$

Se $Q=0$ todas as ramificações ocorrem no segmento terminal e não acontece nenhuma intermediária. Se $Q=1$ só teremos ramificações em segmentos intermediários. Através da variação de $Q$ e $S$ pode-se variar a topologia da arvore dendrítica simulada e obter resultados semelhantes aos biológicos. Diversos tipos de ramificações dendríticas podem ser obtidas por esse modelo, mesmo não havendo nenhum parâmetro biológico ou químico que pode reger os parâmetros $Q$ e $S$. Em 1997, van Pelt e Uylings desenvolveram uma extensão do modelo $Q S$, denominado modelo $B E$, e que posteriormente também foi estendido vindo a se chamar BESTL [Van Pelt(1997)]. No modelo BESTL, o parâmetro $Q$, que determina a probabilidade com a qual um segmento intermediário se ramifica é colocado em 0 , indicando que as ramificações ocorrem apenas nos segmentos terminais. No modelo BESTL temos a incorporação do parâmetro $S$ do modelo $Q S$, do parâmetro $T$, mapeamento da escala de tempo em na escala de tempo real, e do $L$, tamanho do segmento dendrítico. Através da incorporação desses parâmetros, o padrão de ramificação e a geometria topológica das árvores simuladas se assemelham aos resultados experimentais biológicos. Desse modo, esse modelo é capaz de simular um grande número de tipos de neurônios e os diferentes estágios de crescimento. O período de simulação do desenvolvimento dendrítico é dividido em $N$, e para cada tempo $i$ um segmento terminal é aleatoriamente escolhido para ramificar com probabilidade dada pela Equação (6).

$$
P_{i}=\frac{B}{N n_{i}^{E}}
$$

onde $B$ representa o número de eventos de ramificação que ocorre em um segmento isolado. O parâmetro $E$ denota a dependência da probabilidade de ramificação no número total $n_{i}$ de segmentos terminais na árvore em crescimento. Se $E=0$ a probabilidade de ramificação é uma constante em todos os segmentos terminais e independe do número de segmentos terminais na árvore, se $E=1$ então a 
probabilidade de ramificação diminui linearmente com o aumento do número de segmentos terminais.

Além desses modelos, Coelho(2002) desenvolveu uma modelagem de células neurais baseadas em medidas extraídas de células ganglionares de gato. Com o objetivo de gerar neurônios que apresentassem semelhanças morfológicas estatísticas com os naturais, foram inseridas descrições estatísticas baseadas em medidas de dimensão fractal, área de influência, comprimento de arco, tamanho e largura da ramificação, dentre outras, todas retiradas dos neurônios naturais.

\section{(a.2) Modelos baseados em Processos de Ramificação}

Os modelos do tipo process driven simulam os mecanismos gerais de elongações do axônio e das ramificações baseados em mecanismos biológicos fundamentais. Apesar das ramificações serem atribuídas diretamente a um possível evento do citoesqueleto, os padrões dendríticos produzidos pelo modelo podem não ter nenhuma semelhança quantitativa com a arborização dendrítica de células reais.

Albinet e Pelce desenvolveram um modelo que leva em conta uma pequena natureza fractal dos dendritos [Albinet(1996)]. Neste modelo proteínas internas se difundem através da membrana e interagem com um quimioatrator gerando um crescimento adicional. O modelo é capaz de gerar dendritos com padrões fractais.

O modelo dendrítico de Hentschel e Fine de 1994 e 1996 foi baseado no cálcio como um agente morfogênico do neurônio [Hentschel(1994), Samuels(1996) Hentschel(1996)], seguindo a sugestão de Goslin e Banker [Banker(1991) e Lasek(1986)] que levantaram a hipótese de que os determinantes químicos de crescimento, neste caso o cálcio, seriam produzidos no soma e levados até os neuritos, onde seriam consumidos durante o processo de crescimento. Dependendo da identidade desses determinantes químicos, o consumo poderia ser visto como a polimerização de monômeros do citoesqueleto, a adição de MAPs (proteínas associadas de microtúbulos) aos microtúbulos, ao consumo de energia da agregação do citoesqueleto, ou a adição de nova membrana.

No modelo proposto em [Hentschel(1994)], instabilidades na geometria da superfície da membrana resultam em um crescimento localizado da razão da área da superfície pelo volume em certos pontos, ou seja, aparentemente, o mesmo processo 
é gerado em cada neurito. Contudo, uma instabilidade ocorre e acelera a taxa de crescimento de apenas um determinado neurito.

Um fenômeno forte do modelo é a emergência do aumento do gradiente do cálcio de níveis baixos no corpo celular para níveis altos quanto mais distante do dendrito. Este gradiente de cálcio resulta na emergência espontânea de gradientes de sódio e potencial da membrana, vistos ao longo de neurônios reais. O modelo proposto por Hentschel e Samuels [Samuels(1996)] será descrito detalhadamente na seção posterior.

Em 1998, Tim Hely [Hely(1998)] apresentou um modelo bem completo de crescimento de ramificações baseado em interações entre o cálcio, CaMKII, MAP2, e microtúbulos. Enquanto, MAP2 são proteínas associadas aos microtúbulos encontradas nos dendritos, e CaMKII é uma proteína que realiza a fosforização do MAP2, inibindo o agrupamento dos microtúbulos e também inibindo a habilidade do MAP2 de cruzar filamentos de actina.

O modelo consiste em um modelo Compartimental que possui inicialmente um soma esférico e um curto dendrito cilíndrico. Em cada compartimento calcula-se a concentração de cálcio, a sua capacidade de difusão, e a de MAP2 livre (MAP2 $2_{u}$ ). A quantidade de influxo de cálcio é proporcional a razão área de superfície/volume do dendrito. As simulações são feitas em tempos discretos, e a cada passo no tempo o tamanho do terminal dendrítico cresce proporcional a quantidade de $\mathrm{MAP} 2_{\mathrm{b}} / \mathrm{MAP} 2_{\mathrm{p}}$, onde $\mathrm{MAP} 2_{\mathrm{b}}$ são os MAP2 presos e MAP2 $2_{p}$ é o MAP2 fosforilado pelo CaMKII. Quanto maior a proporção do MAP2 fosforizado, maior a probabilidade de ramificação. Assim, novos compartimentos são adicionados e o dendrito cresce, novos segmentos filhos são criados cada vez que um segmento terminal se ramifica.

O modelo é baseado em uma reação que ocorre no interior do soma e dendritos, e as duas variáveis dinâmicas são o cálcio e o MAP $2_{\mathrm{u}}$, determinando diretamente as concentrações de $\mathrm{MAP}_{\mathrm{p}}$ e $\mathrm{MAP} 2_{\mathrm{b}}$. Assim, a taxa de mudança do cálcio e de $M A P 2_{u, p, b}$ são calculados usando quatro equações diferenciais. Apresentamos em Eq. (7) apenas a equação diferencial que descreve a dinâmica do cálcio, as equações mostrando a dinâmica dos $\mathrm{MAP} 2_{\mathrm{u}, \mathrm{p}, \mathrm{b}}$ e outros derivados podem ser vistas em [Hely(1998)]. 


$$
\begin{aligned}
\frac{\partial C a}{\partial t}= & -D_{c a} \frac{\partial^{2} C a}{\partial x^{2}}+I-\delta_{C a} C a \\
& \text { Difusão }+ \text { Influxo }+ \text { Decaimento }
\end{aligned}
$$

O modelo apresenta versões linear e não-linear. Ambos apresentam esquemas de reação idênticos e diferem apenas nas funções de fosforização e desfosforização e nas funções que controlam a taxa de elongação e de probabilidade de ramificação.

No modelo linear, a função que controla a taxa do $M A P 2_{b}$ para o MAP $2_{p}$ é linearmente dependente do cálcio. A desfosforização, que controla a reação de $\mathrm{MAP} 2_{\mathrm{p}}$ para o $\mathrm{MAP} 2_{\mathrm{b}}$, é independente do cálcio. Além disso, o crescimento dendrítico e a sua probabilidade são definidos como apresentado nas Equações (8) e (9).

$$
\begin{gathered}
\text { Crescimento Dendrítico = taxa de elongação } \times \frac{M A P 2_{b}}{M A P 2_{b}+M A P 2_{p}} \\
\text { Probilidade de Ramificação = taxa de ramificação } \times \frac{M A P 2_{p}}{M A P 2_{b}+M A P 2_{p}}
\end{gathered}
$$

Assim, quanto maior a razão entre $\mathrm{MAP} 2_{\mathrm{b}} / \mathrm{MAP} 2_{\mathrm{p}}$ maior a taxa de elongação, e quanto maior a taxa $\mathrm{MAP} 2_{\mathrm{p}} / \mathrm{MAP} 2_{\mathrm{b}}$, maior a probabilidade de ramificação.

No modelo não-linear a função de fosforização aumenta linearmente com o cálcio, enquanto a função de desfosforização é independente do cálcio. As funções que descrevem o crescimento dendrítico e a probabilidade de ramificação podem ser vistas nas Equações (10) e (11).

$$
\text { Crescimento Dendrítico }=\text { taxa de elongação } \times M A P 2_{b} \frac{M A P 2_{b}}{M A P 2_{p}}
$$

$$
\text { Probilidade de Ramificação }=\text { taxa de ramificação } \times M A P 2_{p} \frac{M A P 2_{p}}{M A P 2_{b}}
$$


Neste caso, a função reflete que é necessária uma determinada quantidade de MAP2 para que exista o crescimento ou ramificação, e que altas concentrações de $\mathrm{MAP} 2_{\mathrm{b}}$ geram crescimento rápido, enquanto altas concentrações de $\mathrm{MAP} 2_{\mathrm{p}}$ produzem um número maior de ramificações.

Os resultados encontrados pelos dois modelos conseguiram reproduzir uma grande variedade de células. Além disso, o modelo não-linear foi ainda capaz de reproduzir resultados biológicos dos dendritos das células piramidais basais do rato [Bray(1973)].

Outro modelo de desenvolvimento neural foi proposto em 1999 por Arjen van Ooyen [Van Ooyen(1999)]. No modelo teórico é previsto a competição de conexões nervosas sob a ação de neurotrofinas. De acordo com o modelo, o crescimento de um receptor de neurotrofina determina qual padrão o alvo da inervação vai desenvolver, e que a competição é influenciada por fatores dependentes e independentes da atividade elétrica do neurônio.

\subsubsection{Modelo de Crescimento Neural}

A partir da revisão de modelos apresentados até o momento, podemos verificar que existem inúmeras abordagens e modelos que são capazes de descrever o desenvolvimento de estruturas neurais. Entretanto, nenhum deles apresenta uma preocupação tão grande com a forma como apresenta o modelo de crescimento neural desenvolvido por Samuels, Hentschel e Fine em 1996 [Samuels(1996)] e iniciado por Hentschel [Hentschel(1994)]. A sua principal característica é o seu realismo biológico, tanto através da grande quantidade de detalhes biológicos do desenvolvimento do neurônio, quanto em relação a sua forma. A simulação de crescimento neural baseia-se na modificação da forma final do neurônio sob a presença da diferença de concentração de cálcio entre o meio interior e o exterior da membrana neural, com o cálcio atuando como agente morfogênico. Muitas pesquisas [Lasek(1986), Banker(1991)] mostram que o cálcio encontra-se ligado a produção de microtubulinas, que formam o citoesqueleto e é o responsável pela rigidez e sustentação da membrana celular, logo a concentração de cálcio atua diretamente na sua forma. A seguir, apresentamos os principais estágios do modelo e os resultados da implementação deste modelo em Matlab. 


\section{- $\quad$ Modelo de Crescimento Neural de Samuels, Hentschel e Fine}

O objetivo principal do modelo é estimular o crescimento de um neurônio, de modo a determinar se a atividade elétrica da membrana influencia na formação do axônio. Também foi proposto que o modelo fosse o resultado da interação entre três sistemas: (i) a membrana celular, (ii) a distribuição de íons na célula e (iii) as proteínas do citoesqueleto. O modelo adotado considera uma célula neural bidimensional em uma grade, tal que a membrana celular é representada por uma curva fechada, com pontos $(x, y)$ na grade. No início da simulação o neurônio é tomado como um círculo de raio pré-definido. A seguir, descreveremos as fases do modelo.

\section{(a) Proteínas do Citoesqueleto}

Como comentado, as tubulinas formam a base da membrana celular e também são responsáveis pela forma apresentada pelo neurônio. São filamentos cuja taxa de polimerização $\left(v_{\text {protein }}\right)$ afeta o crescimento do neurônio. A sua representação no modelo é feita através de campos vetoriais ao longo da membrana, onde sua direção representa a orientação das proteínas e a magnitude a sua taxa de polimerização. Como se adota que a concentração de íons de cálcio influencia sua magnitude [Samuels(1996)]], ela é definida como mostra a Eq. (12), onde $A$ é a área da seção transversal e $\rho_{C a}$ a concentração de cálcio.

$$
v_{\text {protein }}=A \rho_{C a}
$$

A velocidade de crescimento do citoesqueleto é determinada por um vetor em cada ponto da membrana que se move na direção normal à superfície com intensidade dada pela magnitude da Eq (13). Assim para cada ponto da membrana teremos um vetor velocidade do tipo:

$$
v_{\text {membrane }}=\left(v_{\text {protein }} . \hat{n}\right) \hat{n}
$$


onde podemos notar que através das Eq. (12) e (13), quanto maior a concentração de cálcio em um determinado ponto da membrana, maior será a velocidade e mais rápido será o crescimento de um dendrito. Inicialmente, as protuberâncias da membrana são criadas pelo crescimento do citoesqueleto na direção normal a membrana, mas essas proteínas longas e rígidas tendem a se alinhar paralelas a membrana celular conforme elas crescem. Assim, conforme o dendrito se estende, a normal a superfície rotaciona e a membrana muda de forma. A taxa de rotação em relação à normal é dada por $v_{\text {protein }} / r_{\text {min }}$, onde $r_{\min }$ é uma constante definida como o mínimo raio de curvatura de uma proteína.

\section{(b) Concentração de Cálcio}

Definidas as velocidades e as regras de crescimento ao longo da membrana, precisamos conhecer a distribuição da concentração de cálcio no interior da célula para podermos calcular a taxa de crescimento das proteínas do citoesqueleto. Essa variação de concentração em seu interior é dado basicamente pela Equação de Laplace, na Eq. (14), para as concentrações dos íons considerados. Apesar de utilizarmos apenas o cálcio como responsável pelo crescimento, calculamos também as distribuições dos íons sódio e potássio interno e externo a célula, pois eles influenciam na condutividade da membrana.

$$
\nabla^{2} \rho=0
$$

Os valores das concentrações dos íons podem ser encontrados através da resolução da Eq. (14). No caso do neurônio, a situação de contorno na membrana é dada pela Eq. (15), onde $D$ é a constante de difusão e $I$ a corrente iônica ao longo da membrana celular.

$$
D \nabla \rho=-I \hat{n}
$$


Entretanto, a condição de contorno não é tão fácil de se especificar, pois como o neurônio possui atividade elétrica, precisamos primeiro conhecer o potencial ao longo da membrana para depois calcularmos a corrente.

O modelo considera uma variação de concentrações de íons de cálcio $\left(\mathrm{Ca}^{+}\right)$, sódio $\left(\mathrm{Na}^{+}\right)$e potássio $\left(\mathrm{K}^{+}\right)$no interior do neurônio, de forma que eles sejam incluídos no cálculo do potencial e da corrente iônica da membrana. A situação de contorno é dada pela projeção na normal da corrente efetiva na membrana, que será comentada a seguir.

\section{(c) Canais Iônicos e Bomba de Íons}

O modelo inclui duas rotas para o movimento dos íons através da membrana: $(i)$ os canais iônicos e (ii) as bombas de íons. No caso dos canais iônicos, assume-se que a membrana é impermeável e que não permite ser cruzada diretamente pelos íons. Assim, ao invés das proteínas cruzarem diretamente a membrana, o modelo prevê canais que permitem o movimento desses íons. Além disso, a estrutura dos canais muda com o potencial da membrana, abrindo-se e fechando-se dependendo da voltagem, são os responsáveis pela membrana ser ativamente elétrica. O outro modo de movimento dos íons ocorre por meio de proteínas que bombeiam íons através da membrana contra o gradiente de concentração iônica, trabalhando contra o fluxo de difusão dos íons nos canais dependentes da voltagem, prevenindo a célula de chegar no equilíbrio. Como resultado, a corrente total efetiva na membrana, para cada íon $i$ é o resultado do fluxo gerado pelos canais iônicos e pelas bombas de íons, conforme representado na Eq. (16).

$$
I_{i}=\left[V-E\left(\rho_{i}\right)\right] g_{i}+P_{i}\left(\rho_{i}\right)
$$

onde $V$ é o potencial ao longo da membrana, $g_{i}$ é a condutividade iônica do íon específico (caracteriza-se pela sua dependência da tensão - canais iônicos), $P_{i}$ é a corrente iônica proveniente das bombas, e $E$ é o potencial de Nernst.

Para esse caso, tomando-se a contribuição da corrente proveniente das bombas iônicas nula, o potencial entrará em equilíbrio quando o potencial $V$ ficar próximo do potencial de Nernst. A presença do termo das bombas permite que o potencial de 
equilíbrio da membrana seja diferente do potencial de Nernst, gerando uma corrente que neutraliza a difusão do íon através dos canais dependentes da voltagem. Assim, a célula pode controlar a concentração de íons interna.

A dependência da tensão na condutividade iônica $g_{i}$ é determinada pela estrutura dos canais que seletivamente conduzem íons específicos através da membrana. Como os canais contém proteínas cujas formas dependem da tensão, eles se abrem ou fecham de acordo com a forma da proteína, permitindo ou não a condução de íons pela membrana. Tipicamente, cada uma das subunidades de proteína dos canais para um íon específico abre com uma probabilidade sigmóide. Essa forma vem da aplicação da estatística de Boltzmann para um modelo de dois estados (aberto e fechado). $\mathrm{O}$ canal de $\mathrm{Ca}^{+}$é formado por 4 subunidades de proteína condutoras, e o de $\mathrm{Na}^{+}$por 3. Assim, as condutividades iônicas são modeladas pelas Eq. (17) e (18), e a do $\mathrm{K}^{+}$é considerada constante.

$$
\begin{gathered}
g_{C a}=g_{C a, \max } f_{C a}^{4} \\
g_{N a}=g_{N a, \text { max }} f_{N a}^{3}
\end{gathered}
$$

Quando um sinal se propaga ao longo do neurônio, o potencial de ação, $V$, muda rapidamente de valor. Quando não existe nenhum sinal se propagando a voltagem é chamada de potencial de repouso. Quando existe a despolarização da membrana, durante o potencial de ação, o potencial cai a zero e existem algumas subunidades de proteína que se fecham diminuindo a condutividade, mas esse processo não é incluído na simulação.

As bombas de íons são proteínas da membrana que se movem contra o gradiente de concentração e previne a célula de entrar em um equilíbrio de difusão. Existe um grande número de proteínas que servem como bombas de íons, e existem várias bombas de íons para um íon específico. Entretanto, o modelo é resumido assumindo uma bomba simples para cada íon.

A bomba de cálcio é uma função altamente não-linear da razão da concentração de cálcio interna e externa $R_{C a}=\rho_{C a, e x} / \rho_{C a, i n t}$. A propriedade da bomba de cálcio de 
se mover contrária a direção do gradiente é modelada como uma função sigmóide apresentada na Eq. (19).

$$
P_{C a}=\frac{P_{C a, \max }}{1+e^{w_{p, C a}\left(R_{c a}-R_{c a, o n}\right)}}
$$

onde $P_{C a, \max }, R_{C a, \max }$ e $w_{P, C a}$ são parâmetros. Se $R_{C a} \gg R_{C a, o n}$ não existe bomba, mas se $R_{C a}<R_{C a, o n}$ a taxa da bomba aumenta rapidamente com $R_{C a}$. Essa forma representa o tipo mais simples da bomba de íon, uma vez que carrega apenas uma espécie de íon.

Existe um outro tipo comum de bomba de íons, ela é chamada de bomba de troca. Ela baseia-se no mecanismo pelo qual as proteínas transportam uma ou mais espécies de íons em direções opostas através da membrana, trocando efetivamente diferentes íons pelas bombas. As bombas de sódio e potássio são tomadas como bombas simples de troca, onde 2 íons de potássio são bombeados para dentro enquanto 3 de sódio que são bombeados para fora, Eq. (20) e (21).

$$
\begin{gathered}
P_{N a}=\frac{P_{N a, \max }}{1+e^{w_{p, N a}\left(R_{N a}-R_{N a, o n}\right)}} \\
P_{K}=-\frac{2}{3} P_{N a}
\end{gathered}
$$

As equações acima representam um modelo simples de bomba de $\mathrm{Na}^{+}-\mathrm{K}^{+}$. $\mathrm{Na}$ realidade, as taxas das bombas não dependem apenas da razão da concentração de sódio, mas também da razão da concentração de potássio e possivelmente do potencial. Para preservar a eletroneutralidade em cada ponto da membrana, a corrente total $\left(2 I_{C a}+I_{N a}+I_{K}\right)$ é colocada em zero, e usando a equação de corrente para cada íon, encontramos o potencial $V(s)$ ao longo da membrana em cada ponto $s$ da membrana dada pela Eq. (22).

$$
V(s)=\frac{g_{k} E\left(\rho_{k}\right)+g_{N a}(V) E\left(\rho_{N a}\right)+2 g_{C a}(V) E\left(\rho_{C a}\right)-P_{K}-P_{N a}-2 P_{C a}}{g_{k}+g_{N a}(V)+2 g_{C a}(V)}
$$


A voltagem deve ser resolvida iterativamente para $V(s)$, porque as condutâncias são funções da voltagem. Biologicamente, o termo do potássio domina a equação e determina o potencial de repouso (os termos do sódio modulam o potencial de repouso, enquanto as contribuições do cálcio são pequenas). Essas observações são válidas durante o potencial de repouso. Quando ele está em disparo, o cálcio e o sódio dominam.

A equação $V(s)$ possui 2 soluções estáveis [Samuels(1996)]:

- Onde os parâmetros de $g_{C a}$ são escolhidos de tal modo que essa solução tenha uma maior condutividade para o cálcio que a outra solução, assim a simulação produz dendritos. A região da membrana com uma condutividade maior que a média irá desenvolver localmente uma maior concentração de cálcio, o que resulta em uma velocidade de crescimento maior, resultando um maior crescimento dendrítico.

- Onde os parâmetros permitem apenas uma solução, não existe a produção de dendritos, pois a taxa de crescimento é constante ao longo da membrana celular.

\section{- Resolução da Equação Diferencial}

O modelo apresenta o problema de fornecer um conjunto de equações que devem ser resolvidas seguindo uma determinada ordem, visto que algumas equações necessitam de valores calculados anteriormente, cujo procedimento será descrito a seguir.

A parte principal da simulação são as atualizações das concentrações de cálcio, sódio e potássio no interior da célula e na membrana. Esses valores são obtidos pela a solução da equação de Laplace, Eq. (3). A solução dessa equação para as diferentes concentrações dos íons é resolvida usando diferenças finitas em uma grade retangular, e o algoritmo implementado para solução é o Sucessive Over Relaxation, discutido em [Smith(1985)], sujeita as condições de contorno dadas pelas outras equações. Um simples passo da relaxação, da iteração $n$ para $n+1$ para a equação de Laplace, exceto na borda, pode ser visto na Eq. (23). 


$$
\rho_{x, y}(n+1)=(1-\alpha) \rho_{x, y}(n)+\frac{\alpha}{4}\left[\rho_{x+1, y}(n)+\rho_{x-1, y}(n)+\rho_{x, y+1}(n)+\rho_{x, y-1}(n)\right]
$$

$x$ e $y$ denotam as coordenadas da grade, e $0<\alpha<2$ é o parâmetro da relaxação, que é ajustado para aumentar a taxa de convergência.

As condições de contornos dadas pelas equações não são funções lineares da concentração. Desse modo, elas devem ser ajustadas a cada passo da relaxação, de modo a refletir as mudanças nas concentrações, o que torna a técnica bastante lenta.

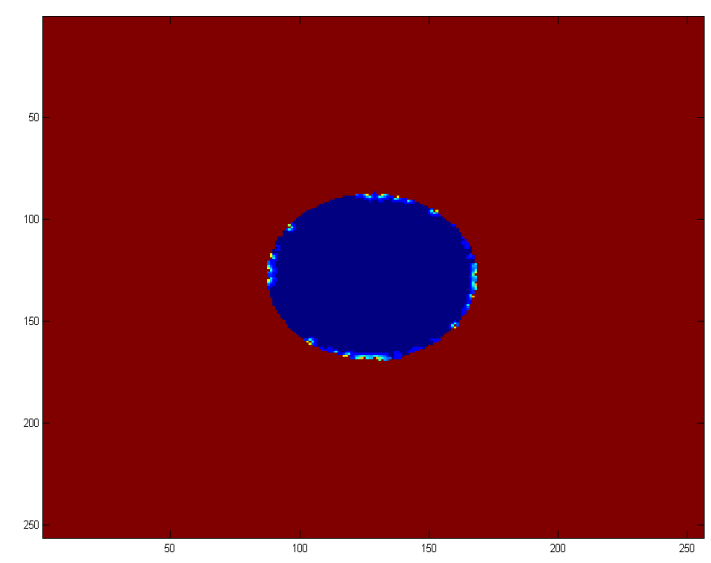

(a)

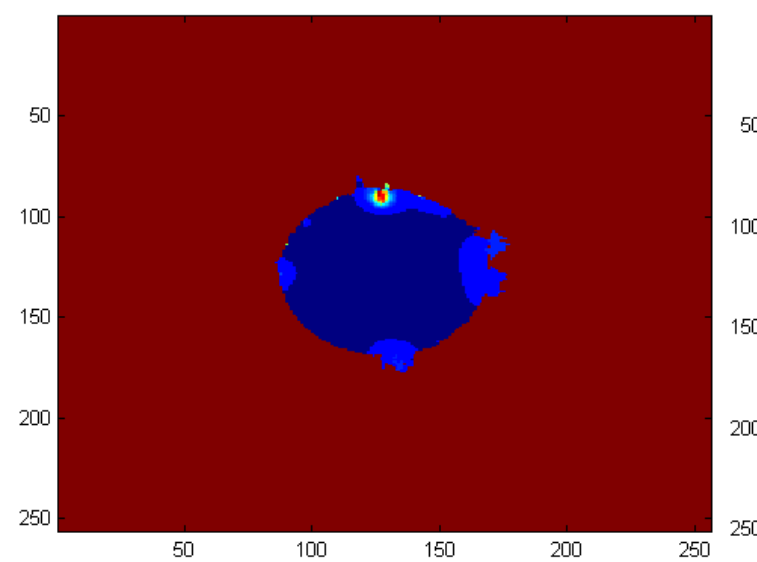

(c)

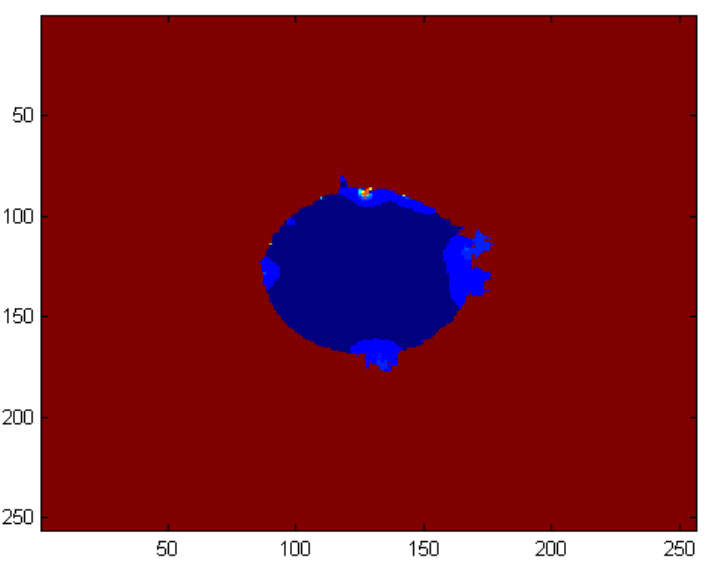

(b)

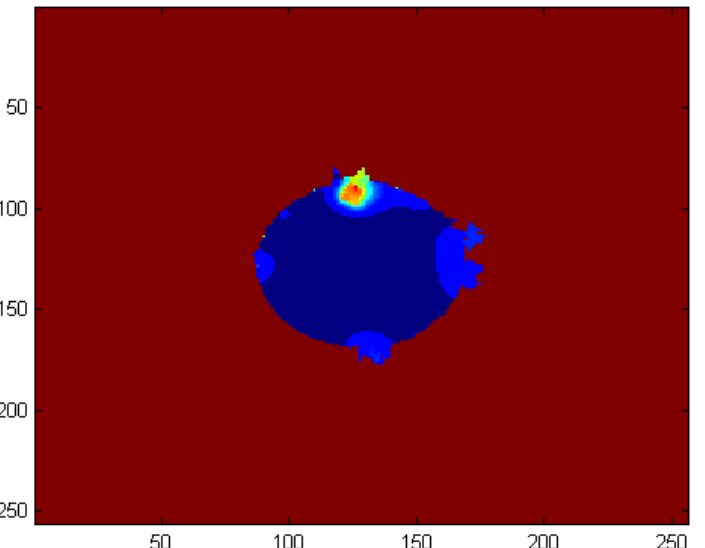

(d)

Figura 7 - Simulação do crescimento do neurônio, as figuras representam a variação de cálcio no interior para 1, 25, 35 e 45 iterações, respectivamente em (a), (b), (c) e (d).

Na Figura 7 apresentamos alguns resultados obtidos da implementação do modelo de crescimento do neurônio. Foram desenvolvidos o programa e consideradas todas as características apresentados nos itens anteriores para a sua 
simulação. As figuras apresentam a variação da concentração de cálcio no interior celular para uma variação ao longo do tempo. Podemos notar através das figuras que conforme o número de iterações aumenta começamos a perceber prolongamentos típicos de ramificações neurais. Em estágios mais avançados da simulação notamos a existência de problemas na borda nas formas dessas ramificações, semelhantes aos primeiros resultados obtidos por Hentschel [Hentschel(1994)]. Apesar de um grande empenho no desenvolvimento dessa simulação, e de colaborações realizadas com o autor, não conseguimos gerar uma estrutura neural semelhante a apresentada em seu artigo [Samuels(1996)]. Considerando o resultado obtido pelos autores, a utilização de hipóteses de crescimento proporcional à variação de cálcio foi capaz de produzir estruturas ramificadas equivalentes a neurônios, corroborando a idéia da importância do citoesqueleto.

$\mathrm{Na}$ realidade, a grande importância do desenvolvimento desse tipo de simulação foram a familiarização com o modelo de desenvolvimento neural, o completo entendimento das hipóteses biológicas sugeridas pelo modelo e qual o tipo de tratamento numérico é dado à elas individualmente. Como o modelo é bastante completo, considerando crescimento de actinas, movimentação da membrana, canais iônios, potencial de membrana e outras, o seu entendimento mostra-se de extrema importância para o desenvolvimento de novos modelos. Por outro lado, o número de variáveis por ele usado é muito grande e, embora ele leve em consideração muitos aspectos físicos e químicos importantes no processo de crescimento do neurônio, sua implementação e a reprodução dos resultados obtidos por Hentschel em [Samuels(1996)] é difícil de ser realizada. Portanto, na proposta do modelo apresentado no próximo Capítulo, consideramos o fato da membrana ser eletricamente ativa, através da atuação do campo elétrico com geometrias diversas na célula, inclusive outros neurônios. Além da importante contribuição do cálcio ao crescimento das actinas e sucessivamente das células, também proposto por Hentschel. É importante observar que a implementação do programa em linguagem Matlab não forneceu bons resultados, não conseguindo reproduzir a estrutura apresentada em [Samuels(1996)]. 


\section{CAPITULO 4: TÉCNICAS COMPUTACIONAIS DE EVOLUÇÃO DE CURVAS}

No Capítulo anterior apresentamos uma breve descrição sobre os modelos de crescimento de uma célula neural baseados quase que exclusivamente no desenvolvimento das actinas e microtúbulos, estruturas internas celulares. Além disso, uma outra estrutura muito importante, que foi discutida mas pouco mencionada é a membrana do neurônio, que tem papel fundamental no controle da forma neural. Poucos modelos levam em consideração a sua variação devido à ação dessas actinas e microtúbulos. Como a membrana celular está intimamente ligada à forma do neurônio, neste Capítulo iremos apresentar métodos matemáticos que sejam capazes de abordar a membrana do neurônio como sendo uma curva fechada. Dentro desse contexto, esse capítulo apresenta técnicas computacionais de evolução de curvas, os métodos Level Set e os contornos ativos, que possibilitam uma abordagem baseada em contornos para a célula neural. As técnicas apresentadas são comumente usadas em processamento de imagens, mas mostram-se ferramentas importantes no tratamento dado as membranas celulares adotado pelo modelo de crescimento a ser apresentado no Capítulo 6.

Durante essas evoluções trataremos uma forma 2D como um conjunto conectados de pontos que descreve o contorno de um objeto. No caso de um processo que evolui ao longo do tempo, também conhecido como processo de morphing, o contorno pode ser descrito por $\vec{c}(s, t)=(x(s, t), y(s, t))$, isto é, uma curva parametrizada ao longo de $s$, que apresenta transformações ao longo do tempo $t$. Na Figura 8, temos um exemplo de uma evolução de um contorno ao longo do tempo $t$, cuja evolução segue transformações geradas por convoluções com gaussianas de diferentes desvios padrões. 


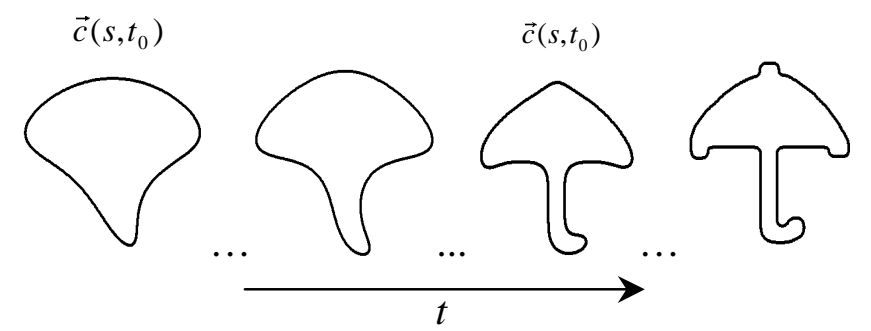

Figura 8 - Representação básica de um processo de morphing [Costa(2001)a].

Podemos adiantar que o processo de morphing pode ser descrito matematicamente de diferentes modos. Entretanto, é muito complicado saber que tipo de transformação leva de uma forma a outra. A descoberta desse tipo de informação assemelha-se ao problema do 'ovo e da galinha' (não se sabe quem vem primeiro), isto é, se conhecermos a transformação sabemos como descrever a forma final, e se sabemos descrever a forma final, necessariamente conhecemos a transformação. A resolução desse tipo de problema é geralmente feita utilizando soluções iterativas. A partir de uma solução proposta inicialmente é possível melhorar o resultado da transformação ao longo de sucessivas iterações na solução do problema.

A natureza das transformações encontradas pode ser bem diversa, temos as geométricas (rotação, translação, escalonamento e etc), as que seguem equações diferenciais (na normal, na curvatura, incluindo métodos Level Set), os mapas funcionais, os modelos de convolução e os funcionais de energia. A seguir, descreveremos duas abordagens matemáticas para a evolução de curvas, o método de Level Set, que se utiliza equações diferencias para descrever evoluções, e a técnica de contornos ativos (Snake), que é baseada na abordagem de funcional de energia para descrição da curva.

\subsection{Métodos Level Set}

A teoria de frentes propagantes, descrita inicialmente por J. Sethian [Sethian(1999)], tem como objetivo fornecer um modelo geral de evolução de vizinhanças, através do conhecimento da velocidade normal de uma dada curva $\gamma(t)$. 


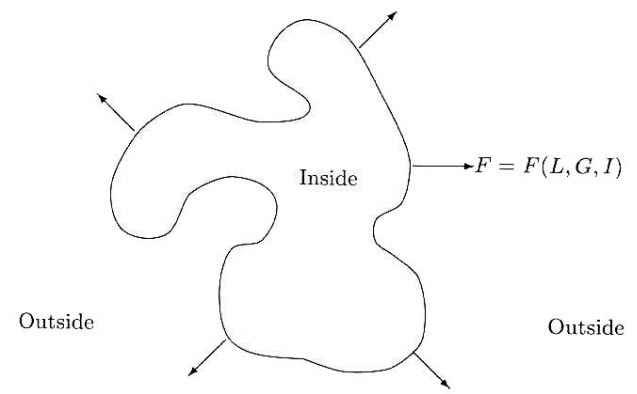

Figura 9 - Curva se propagando com velocidade na direção da normal F [Sethian(1999)].

Suponha a curva apresentada na Figura 9, e imagine que essa curva se movimente na direção normal a ela com uma determinada velocidade conhecida $F$. O objetivo é descobrir como descrever o movimento dessa interface. Supondo inicialmente $F>0$, a interface irá sempre se mover no sentido de expansão. Um modo de caracterizar a posição da frente propagante é calcular o tempo de chegada dela em uma determinada posição, ou seja, o $T(x, y)$ quando ela cruza o ponto $(x, y)$. Considerando múltiplas dimensões a Eq.(24) é utilizada para o movimento da frente.

$$
|\nabla T| F=1
$$

Desse modo, se a velocidade $F$ depende somente da posição, então a Eq. (24) se reduz ao que chamamos de equação Eikonal, cujo exemplo pode ser visto na Figura 10 , onde temos a propagação de uma frente circular com velocidade constante $F=1$.

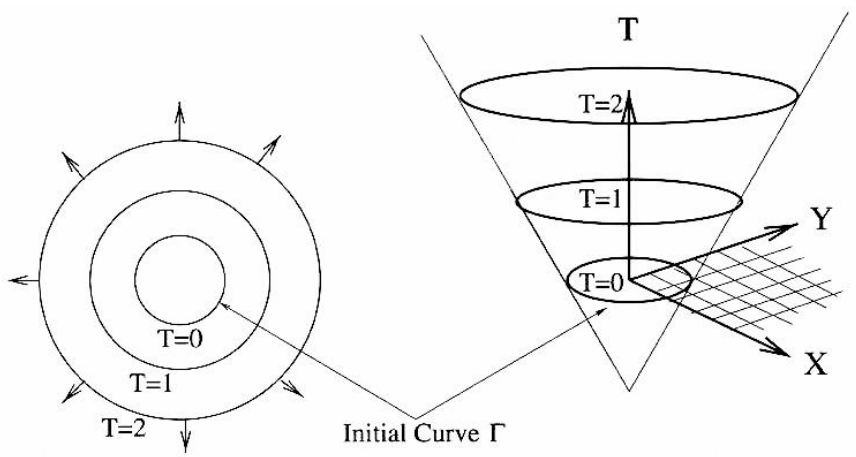

Figura 10 - Propagação de uma frente em função do tempo com velocidade constante [Sethian(1999)]. 
Agora suponha que essa frente possa se propagar tanto no sentido positivo, quanto no negativo, o que faria a função passar pelo mesmo ponto $(x, y)$ várias vezes, de modo que o tempo $T(x, y)$ não seria uma função. Uma maneira para contornar esse problema é tratar a posição inicial da função como o nível zero de uma função $\Phi$ de dimensão maior que a inicial. Com isso podemos associar a evolução da função $\Phi$ com a propagação da frente através de um problema de valor inicial dependente do tempo. Em qualquer tempo, a frente será dada pelo nível zero da função $\Phi$.

Dada uma velocidade $F$ na direção normal, a Eq. (25) representa a evolução da função $\Phi$ ao longo do tempo. Na Figura 11 temos um exemplo da propagação da frente, para diferentes tempos.

$$
\Phi_{t}+F|\nabla \Phi|=0
$$

Esse tipo de formulação possui algumas vantagens, tais como a garantia da topologia das curvas iniciais, uma aproximação com boa precisão computacional, fácil determinação das propriedades geométricas (vetor normal e curvatura), alta eficiência quando usado através de algoritmos rápidos (Fast Marching Methods), além de apresentar vantagens de possibilitar velocidades positivas e negativas.

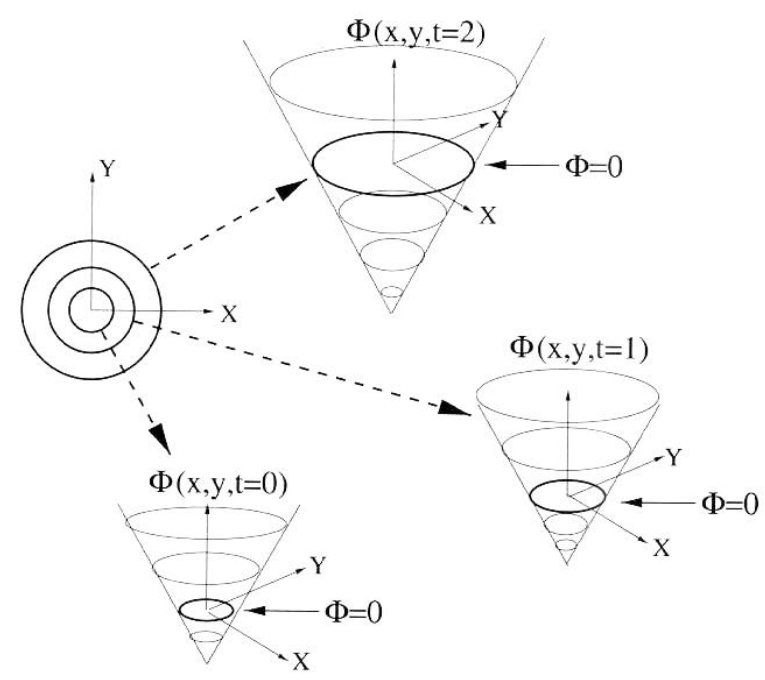

Figura 11 - Exemplo da propagação da frente utilizando a função $\Phi(\mathrm{t})$, onde cada evolução corresponde ao nível zero de $\Phi(\mathrm{t})[\operatorname{Sethian}(1999)]$. 
Através da formulação descrita, J. Sethian apresenta vários tipos de aplicações para a propagação das frentes [Sethian(1999)], através da modificação do tipo de velocidade de propagação, que pode ser constante, proporcional a curvatura, proporcional ao gradiente (detecção de bordas, eliminação de ruído de uma imagem), dentre outros. Na Figura 12, mostramos o resultado da propagação de um contorno com velocidade constante e positiva na direção da normal (b), considerando, para isso, a curva inicial dada em (a).

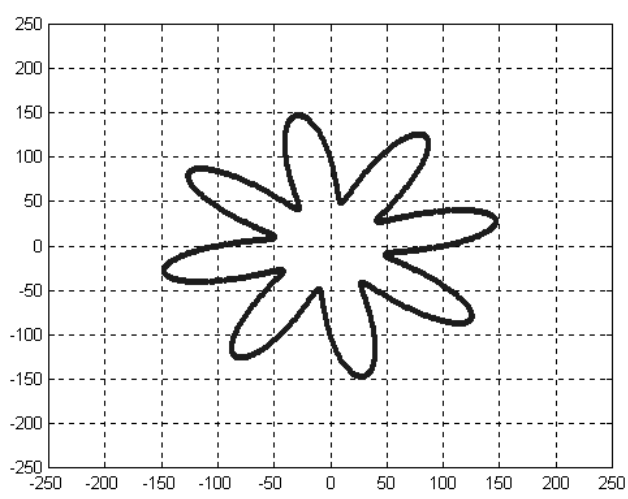

(a)

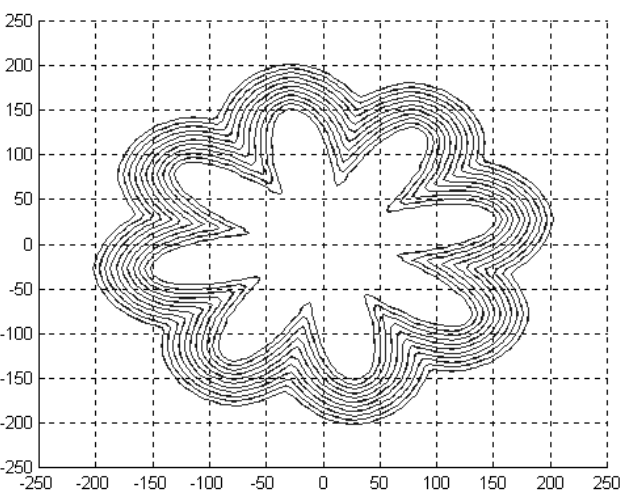

(b)

Figura 12 - (a) Curva analítica inicial e (b) propagação da curva utilizando velocidade constante.

Na Figura 13, mostramos a propagação de um contorno utilizando a velocidade proporcional a curvatura, onde o círculo apresentado em vermelho é a curva final da Figura 12(a) após 100 interações. Para o caso da velocidade ser dependente da curvatura, os pontos de maior curvatura estão relacionados às maiores velocidades, como resultado a figura tende para um círculo.

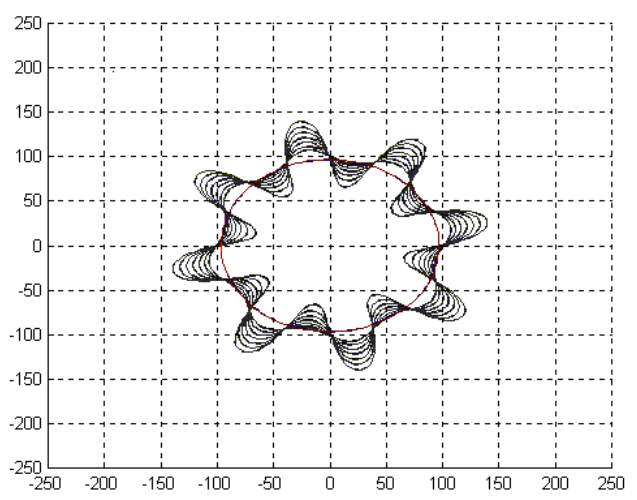

Figura 13 - Propagação da curva utilizando velocidade proporcional a curvatura. 
Existem também aplicações para as propagações de frentes adaptadas às imagens bidimensionais, considerando a velocidade proporcional a curvatura. Na Figura 14(a) temos uma imagem com ruído gaussiano $(\sigma=0.01)$. Essa técnica considera a imagem como uma superfície cujos níveis de cinza são a sua altura. Quando a curvatura é calculada, os pontos de ruído apresentam maior curvatura, logo suas velocidades são maiores, e os ruídos tendem a ser eliminados (pois esses pontos de alta curvatura tendem a se igualar ao ponto médio da vizinhança). Na Figura 14 mostramos o resultado da sua filtragem. A principal característica dessa abordagem de eliminação de ruídos e de propagação de frentes é a sua não linearidade, ou seja, a evolução ocorre diferente e independentemente para cada região da imagem ou da curva, dependendo, por exemplo, da sua curvatura.

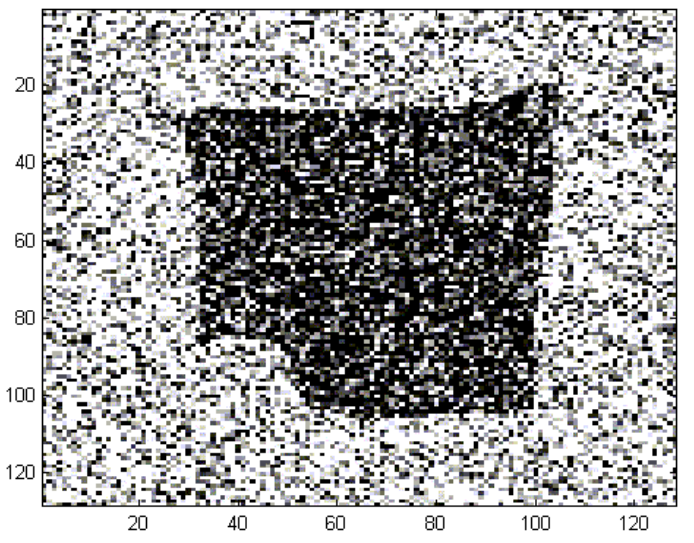

(a)

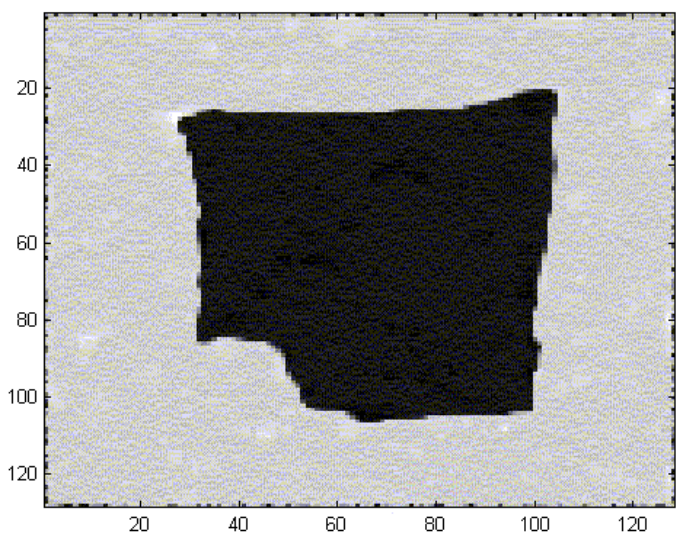

(b)

Figura 14- Imagem inicial com ruído gaussiano em (a) e filtragem utilizando o método de propagação de frentes com a velocidade proporcional a curvatura em (b).

Um dos fatores mais interessantes da teoria de frentes propagantes é que a velocidade pode ser uma função de diversas variáveis, dentre elas: as propriedades locais (curvatura e direção normal), as propriedades da frente propagante (potencial de difusão) e as propriedades independentes (parâmetros independentes da frente propagante). Mais detalhes sobre essa implementação podem ser obtidos em [Sethian(1999)].

Um fato que nos chamou especial atenção neste método foi a utilização da curvatura como um parâmetro proporcional a velocidade, e de conseguirmos obter crescimentos localizados em determinadas regiões. Essas considerações são 
particularmente interessantes porque essa será uma das hipóteses propostas para o desenvolvimento da célula neural no Capítulo 6.

\subsection{Contornos Ativos}

Outros modelos que trabalham com evolução de contornos ao longo do tempo são os modelos de formas ativas, ou active shape models, e suas variações [Blake(1998)]. A sua formulação matemática é baseada em funcionais de energia e em restrições que regem a sua evolução, diferindo da abordagem diferencial das frentes propagantes. De acordo com Blake e Isard [Blake(1998)] esses modelos englobam uma grande variedade de formulações. Ao contrário das propostas de alguns autores, Blake e Isard definem diferenças entre as diversas abordagens, tais como: as Snakes, os modelos deformáveis e os contornos dinâmicos, mostrando que existem diferenças entre as abordagens, inclusive quanto a resolução. A seguir, descreveremos todas as formulações e uma descrição mais detalhada sobre a técnica de Snakes.

A Snake é um mecanismo que utiliza um certo conhecimento à priori da imagem, e impõe condições de continuidade e suavidade no algoritmo. A idéia é extrair um mapa de características (features) da imagem inicial, e tratá-lo como uma superfície (landscape) no qual a Snake, ou curva deformável, pode deslizar e se moldar. De tal resultado é possível definir uma equação para o movimento dessa curva de acordo com as restrições colocadas no problema. Por exemplo, supondo que a superfície inicial seja um filtro com altas respostas para altos contrastes (filtro de detecção de bordas). Nesse caso, o alto contraste tenderá a atrair a Snake para as bordas. As equações de equilíbrio são definidas de tal modo que a Snake tenda a apegar-se às altas respostas do espaço de características, e maximizar o seu valor. Esta tendência de maximizar a função resposta é formalizada como a energia potencial 'externa' do sistema dinâmico. Ela é contrabalançada pela energia potencial 'interna', que tende a preservar a suavidade da curva.

No caso dos modelos deformáveis temos um modelo elástico de uma curva flexível e contínua que é imposto para se adaptar a imagem. Variando-se os parâmetros elásticos pode-se controlar a suavidade dessa curva. O objetivo é 
modificar os valores dos parâmetros da curva de tal modo que a interpolação encontrada tenha a menor energia possível.

Já os contornos dinâmicos englobam as características dos dois modelos comentados e são aplicados dinamicamente quando temos uma sequiência temporal de imagens. A sua implementação necessita de uma conhecimento prévio sobre as deformações e o movimento do objeto. Devemos lembrar que o contorno e o mapa de características varia ao longo do tempo. Logo, a equação de movimento para esse contorno é formulada como a equação da Snake adicionada de um termo proporcional a viscosidade e a inércia.

Entretanto, mais poderoso ainda é combinar essa modelagem dinâmica com as estruturas geométricas usadas em modelos deformáveis. Isso envolve definir um conjunto de formas parametrizáveis, $r(s, X)$, como o modelo deformável e então especificar uma equação dinâmica para a forma do parâmetro $X$. O interessante é que isso pode ser feito em duas fases, onde o modelo dinâmico é usado para predição, para extrapolar o movimento de um passo a outro. Nesse caso, dada a estimativa para a predição, ela é refinada usando os parâmetros medidos nas imagens.

Os modelos deformáveis podem ser divididos em paramétricos e geométricos. Os modelos deformáveis paramétricos representam curvas e superfícies explicitamente na sua forma paramétrica usada durante a deformação. Essa representação permite a interação direta com o modelo e proporciona uma representação mais compacta para sua implementação em tempo real. Já os modelos deformáveis geométricos, podem lidar naturalmente com mudanças topológicas. Esse modelos são baseados em teoria de evolução de curvas e em métodos Level Set [Sethian(1999)]. A seguir apresentamos os detalhes do modelo de Snakes proposto por Kass(1987). O seu entendimento e a sua implementação são de grande importância, pois suas idéias serão utilizadas posteriormente no desenvolvimento do modelo de crescimento neural.

\section{Snakes}

O primeiro modelo de Snakes foi proposto por Kass(1987) e foi utilizado para representar contornos em imagens utilizando iteração com processos de alto nível. A abordagem era baseada em um funcional de energia para definir o contorno, e a 
solução do sistema era dada através de cálculos variacionais. Devido a grande instabilidade numérica dos resultados, em 1992 Williams e Shah [Williams(1992)] propuseram um algoritmo iterativo que permitia a inclusão de restrições no funcional e apresentava uma grande estabilidade. Esse algoritmo é denominado Greedy e até hoje é um dos algoritmos mais utilizados para a solução de uma Snake. Detalhes sobre esse algoritmo podem ser encontrados no Apêndice B.

Em seu trabalho Kass(1987) representa um contorno como um vetor $v(s)=(x(s), y(s))$, onde $x$ e $y$ representam as coordenadas dos pontos do contorno, e $s$ o seu comprimento de arco. O funcional de energia é descrito pela Eq (26).

$$
E_{\text {snake }}=\int_{0}^{1} E_{\text {interna }}(v(s)) d s+\int_{0}^{1} E_{\text {restriçōes }}(v(s)) d s+\int_{0}^{1} E_{\text {imagem }}(v(s)) d s
$$

onde $E_{\text {interna }}$ representa a energia interna do contorno devido a dobramentos e descontinuidades, $E_{\text {imagem }}$ é a força referente a imagem e $E_{\text {restrições }}$ é a força referente a restrições externas da função.

No caso do algoritmo Greedy proposto por Williams e Shah [Williams(1992)] o funcional de energia a ser minimizado é dado pela Eq. (27), muito similar a Eq. (26).

$$
E=\int_{0}^{1} \alpha(s) E_{\text {continuidade }}(v(s)) \mathrm{ds}+\int_{0}^{1} \beta(s) E_{\text {curvatura }}(v(s)) d s+\int_{0}^{1} \gamma(s) E_{\text {inagem }}(v(s)) d s
$$

Nesta equação, o primeiro e o segundo termo são, respectivamente, os parâmetros de continuidade de primeira e segunda ordem e são referentes a energia interna da função, enquanto o terceiro termo refere-se a imagem original. Os parâmetros $\alpha, \beta$ e $\gamma$ são usados para balancear a influência relativa entre os três termos da equação. A Eq. (27) também pode ser descrita através da Eq. (28).

$$
E=\int_{0}^{1} \alpha(s)\left|v_{s}(s)\right|^{2} \mathrm{~d} s+\int_{0}^{1} \beta(s)\left|v_{s s}(s)\right|^{2} d s+\int_{0}^{1} \gamma(s) E_{\text {gradiente }}(v(s)) d s
$$

O primeiro termo da Eq. (28) é uma derivada de primeira ordem e tende a altos valores quando uma descontinuidade é encontrada na curva. O segundo termo é uma derivada de segunda ordem, que tenderá a valores elevados quando a curva se dobrar 
rapidamente (analogia a curvatura), enquanto os valores de $\alpha$ e $\beta$ determinam quais pontos podem ser esticados ou entortados. Por exemplo, altos valores de $\beta$ fazem o termo de segunda derivada ser maior que os outros. Assim o mínimo valor de energia ocorre quando a curva for mais suave, se aproximando de um círculo no caso de curvas fechadas. Se $\alpha=0$ no ponto é sinal de que uma descontinuidade pode ocorrer, enquanto $\beta=0$ significa que um canto pode ocorrer.

A Snake nos dá uma idéia de variação da forma em função de sua curvatura, criando uma analogia com o crescimento biológico, onde regiões de ponta das ramificações (alta curvatura) tendem a possuir um crescimento maior que outras porções da célula, sendo que ao mesmo tempo conseguimos manter uma certa suavidade e rigidez na curva. 


\section{CAPÍTULO 5: IMAGENS NEURAIS E MEDIDAS NEUROMORFOMÉTRICAS}

Além do desenvolvimento de modelos neurais, uma outra ênfase dada a essa tese foi a implementação de medidas morfométricas extraídas de imagens de neurônio. A utilização dessas medidas visam um estudo mais detalhado da forma neural ao longo do crescimento da célula e também em células já adultas. Além disso, elas também vêm sendo utilizado como importantes ferramentas na caracterização de células neurais [Costa(1997), Costa(1999)b] seja para a classificação, ou, para a validação qualitativa dos modelos de crescimento neural apresentados.

As medidas neuromorfométricas e o estudo da evolução da célula neural são realizadas sobre dois conjuntos de imagens: um conjunto de imagens de células já adultas (células ganglionares) e um conjunto de imagens de células em crescimento. As características dos dois conjuntos de imagens e como elas foram obtidas são descritos nas Seções 5.1 e 5.2. Apresentamos a extração de diversas medidas das células, tais como: área, perímetro, largura e ângulo de ramificação, hierarquia, obtidas através de uma estrutura denominada esqueleto da imagem (representação bidimensional e afinada do objeto a ser estudado). A partir do esqueleto foram gerados dendogramas automáticos das imagens de neurônios, estruturas que representam as hierarquias das ramificações. Além disso, também apresentamos a medida de dimensão fractal cujo aperfeiçoamento usando a técnica de dilatação exata e a extração da derivada da curva do log área vs log do raio, permitiram resultados mais preciso e que variassem ao longo de escalas.

\subsection{Imagens de Células Ganglionares}

O primeiro conjunto de imagens neurais utilizado são imagens de uma cultura de células ganglionares adultas da retina do roedor conhecido como Furão, sem a ação de neurotrofina, situação Control (CTR) e com o fator de crescimento NT-4 (NT-4). As imagens são estáticas e não reproduzem o crescimento ao longo do tempo. O 
objetivo maior é investigar a variação morfológica das células para os fatores de crescimento utilizados. Esse fato é particularmente interessante, pois a partir dele é possível determinar características morfométricas específicas para um determinado fator de crescimento, associando esses dados à tendência de crescimento de cada um deles, uma vez que sabemos que os fatores de crescimento são substâncias químicas que influenciam na seleção do alvo pelas ramificações.

As imagens foram obtidas através da técnica de microscopia confocal, que se baseia na obtenção de uma imagem 3D de um dado elemento através da projeção de diversas imagens 2D em diversos planos focais da imagem. Embora os dados apresentados sejam tridimensionais, foram utilizadas apenas projeções bidimensionais dessas imagens. Na Figura 15, apresentamos algumas imagens obtidas de neurônios, para os dois fatores de crescimento obtidas em um dia de cultura. As imagens da Figura 15(a) e (b) apresentam células ganglionares obtidas sob a ação de CTR e (c) e (d) sob a ação do NT-4.

Apesar da microscopia confocal gerar imagens com boa resolução, podemos notar um grande número de arborizações e o cruzamento entre elas, fato que contribui negativamente para um dos passos essenciais na extração de medidas, a segmentação. Além disso, esse comportamento contribuirá para a indecisão quanto à ramificação pertencer ou não ao neurônio em estudo. As obtenções das imagens neurais foram o resultado de uma colaboração com a neurocientista Alejandra Bosco, pesquisadora na Universidade Federal do Rio de Janeiro. 


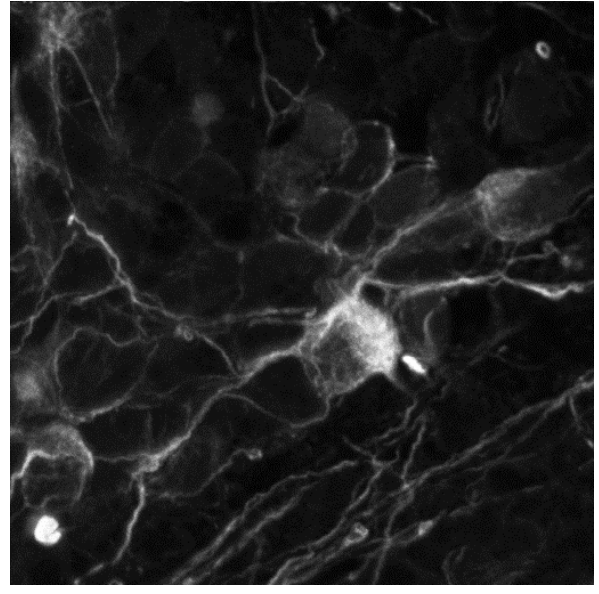

(a)

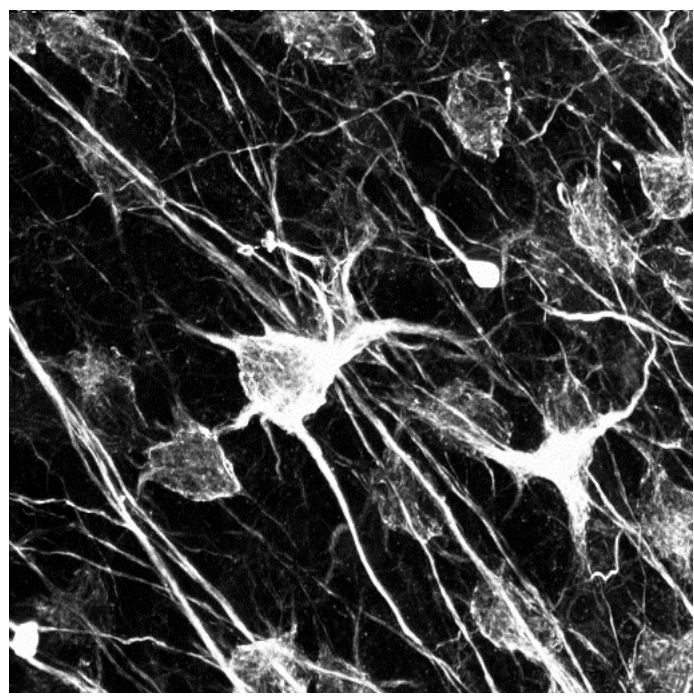

(c)

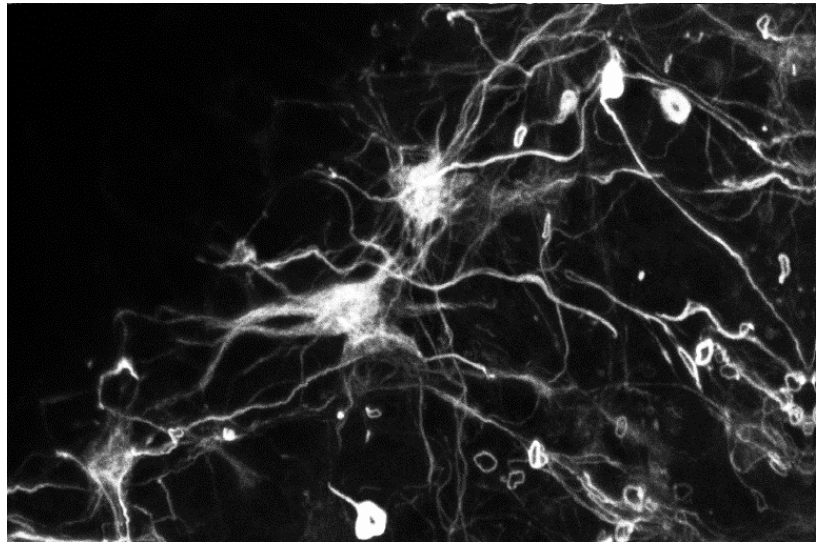

(b)

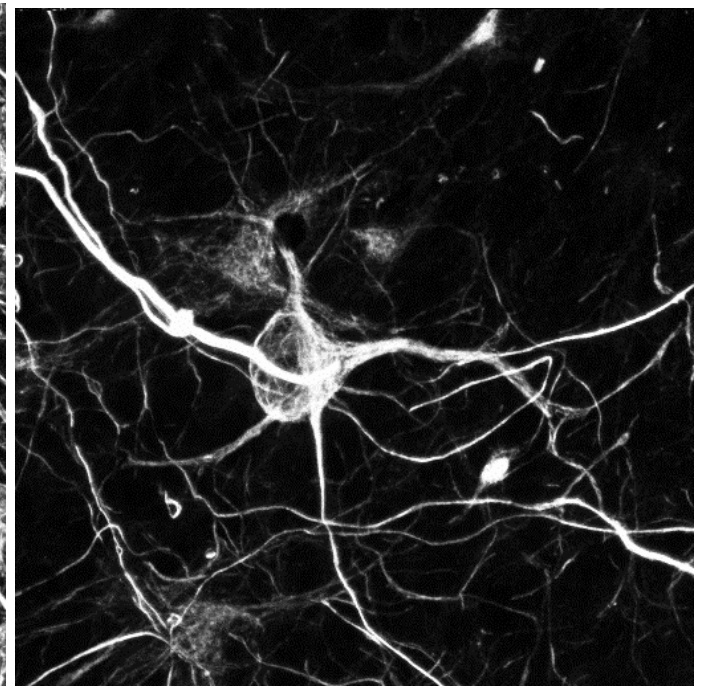

(d)

Figura 15 - (a) e (b) apresentam células ganglionares da retina do Furão na situação $C T R$, e (c) e (d) células ganglionares da retina do Furão sob a ação do NT-4.

\subsection{Imagens de Células em Evolução}

O nosso interesse particular em imagens celulares é a observação da evolução das células neurais e o registro dessa informação dinâmica da forma celular com o tempo. A obtenção de imagens de células neurais reais em crescimento funciona como um laboratório para as hipóteses de crescimento que serão consideradas. Essas imagens foram obtidas através de uma colaboração com pesquisadoras que possuíam conhecimento na área de culturas celulares, as Profs. Dra. Marinilce F. Santos e Dra. Dânia Hamassaki-Britto, do Instituto de Biociências (ICB) da USP de São Paulo. 
Foram acompanhados experimentos de cultura de células neurais aproveitando a infraestrutura do laboratório de Biologia Celular da Retina do ICB, onde extraímos imagens de células durante o seu desenvolvimento. Foram utilizadas células da linhagem Neuro-2A (neuroblastomas de rato) obtidas do Banco de Células do Rio de Janeiro (Bank \#CR098). A cultura foi realizada em materiais da Corning Glass Works com meio e outros reagentes obtidos da Gibco e Sigma. As células foram crescidas e humidificadas em uma incubadora a $37{ }^{\circ} \mathrm{C}$ em atmosfera de $95 \%$ ar e 5 $\% \mathrm{CO}_{2}$. O meio utilizado para a cultura era composto por glicose, soro fetal bovino, penicilina, sulfato de estreptomicina e L-Glutamina. Para os experimentos, as células foram plaqueadas a uma proporção de $1,0 \times 10^{5} / \mathrm{mm}$ em discos de Petri e deixadas no meio e na incubadora por um período de 2 dias, antes de iniciarmos a aquisição das imagens. Após esse período inicial de adesão das células às placas, essas eram levadas a um microscópio para a análise do crescimento das ramificações em células individuais.

O equipamento utilizado para a aquisição das imagens foi uma Worskstation da Cell Robotics, que possui um computador com uma placa de aquisição de TV/Vídeo e câmaras CCDs acoplados a um microscópio Zeiss Axiovert 100/135, possibilitando a aquisição de imagens do microscópio em tempo real. Os discos de Petri eram acoplados a uma plataforma do microscópio capaz de se mover em 8 direções diferentes sob o comando de um controle manual. O programa do equipamento possibilita guardar as coordenadas de uma célula visitada, assim podemos retornar a mesma célula após um certo período de tempo. Em cada placa escolhemos entre $10 \mathrm{e}$ 15 células, cujas imagens eram adquiridas e visitadas novamente em intervalos de aproximadamente $10 \mathrm{~min}$. Após um período de aproximadamente de $30 \mathrm{~min}$ retornávamos a placa à incubadora, enquanto realizávamos medidas em uma outra placa. Após cerca de 1 hora, retornávamos a placa inicial ao microscópio para acompanharmos novamente as células já marcadas. Tal procedimento se repetiu para todas as células. Entretanto esse procedimento não forneceu bons resultados para todas as seqüências, pois como a placa era retirada do seu ambiente com temperatura e atmosfera controladas, em muitos dos casos a célula era levada à morte, ou seja, ao invés de observarmos o crescimento de neuritos ao longo do tempo, observávamos o retraimento desses prolongamentos. Esse comportamento nos levou a buscar outras alternativas para a obtenção dessas imagens, tais como, o acoplamento de uma base 
aquecida no microscópio sobre o qual ficava a placa de Petri com as células. Porém, esse procedimento também não resultou em sucesso na aquisição das imagens. Além disso, mesmo quando a célula não morria observamos que os intervalos entre guardar a célula na incubadora e voltá-la ao microscópio era muito grande (ca. $1 \mathrm{~h}$ ), pois a modificação das ramificações eram muito bruscas e muito difíceis de serem acompanhadas por um modelo, devido, principalmente, a grande incerteza gerada entre as correspondências das duas imagens sucessivas. Sendo assim, para vencer esse problema, realizamos experimentos posteriores onde cada seqüência foi observada em intervalos de tempo menor (ca. $3 \mathrm{~min}$ ) e o tempo para retirá-la e colocá-las na incubadora foi diminuido para $30 \mathrm{~min}$. Também realizamos experimentos com uma mesma placa cujo tempo total era de aproximadamente 30 min onde observávamos uma mesma célula em intervalos de 1 min.

A seguir apresentaremos alguns exemplos de seqüências de imagens obtidas de células neurais em crescimento e em intervalos de tempo de ca. 3 min. A Figura 16 apresenta uma das primeiras seqüências de imagens obtidas, onde notamos a grande modificação das ramificações ao longo do tempo. Já na Figura 17 temos uma seqüência que apresenta um maior número de imagens em instantes menores de tempo, ca. $1 \mathrm{~min}$. 


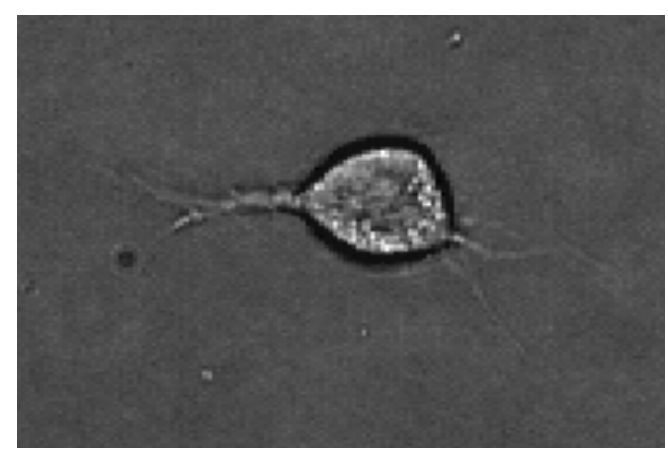

(a)

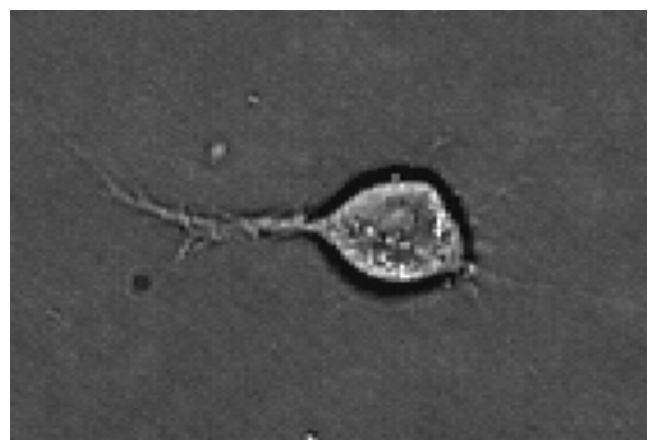

(c)

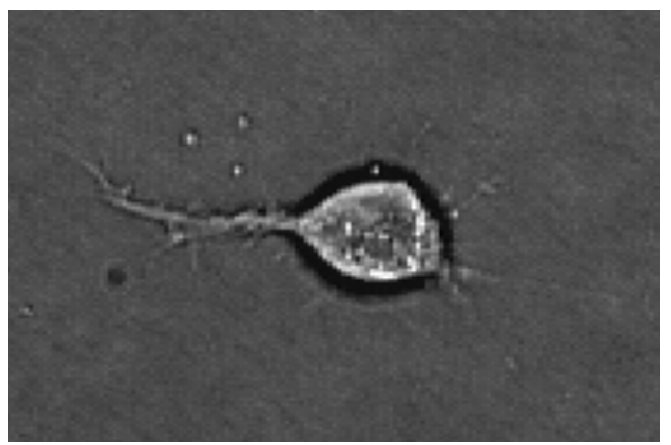

(e)

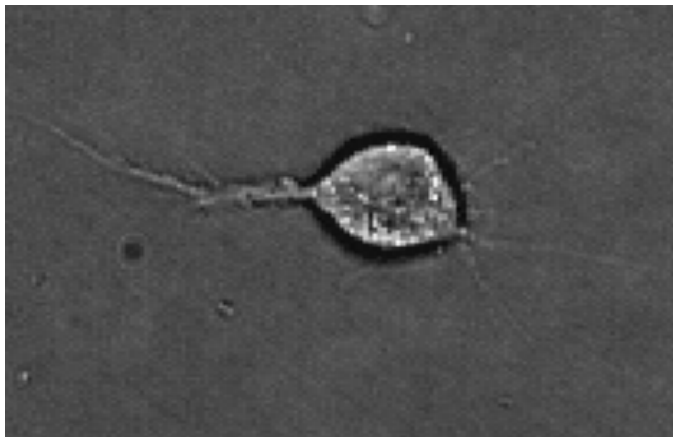

(b)

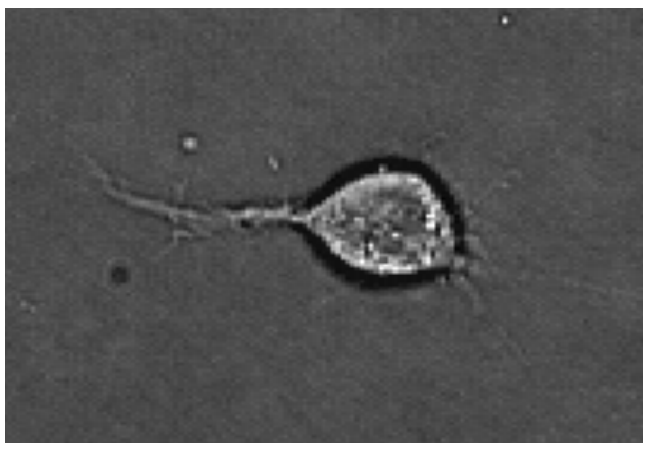

(d)

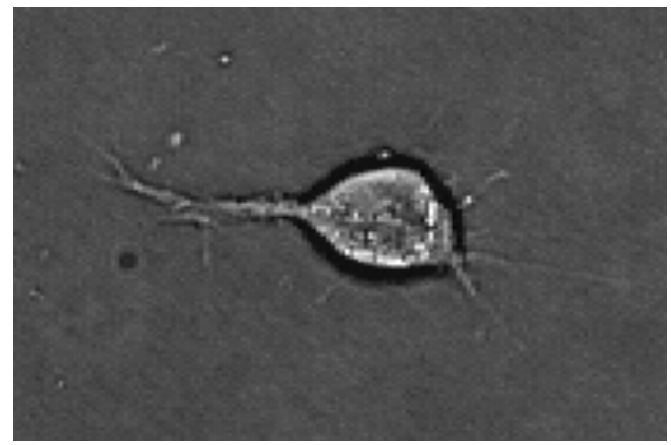

(f)

Figura 16 - Seqüência de imagens de célula em cultura.

Nas imagens de neurônios apresentadas na Figura 16 notamos uma grande variação nas ramificações ao longo do tempo. 


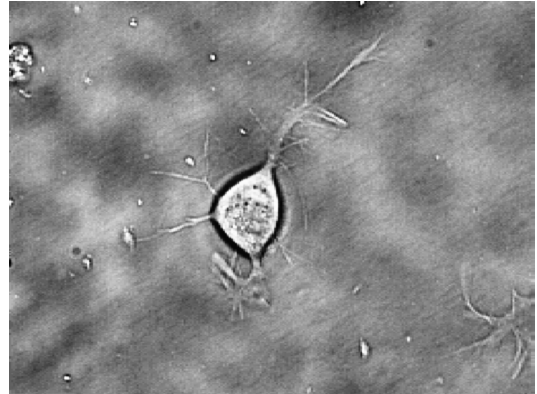

(a)

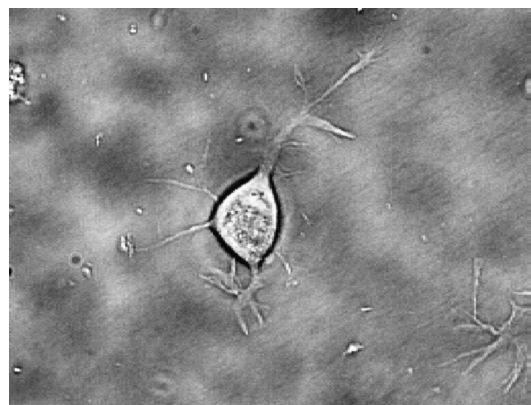

(d)

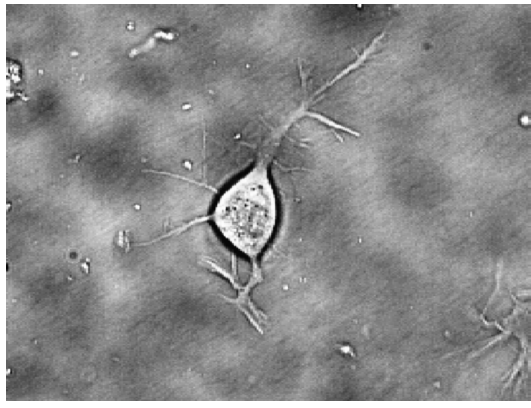

(e)

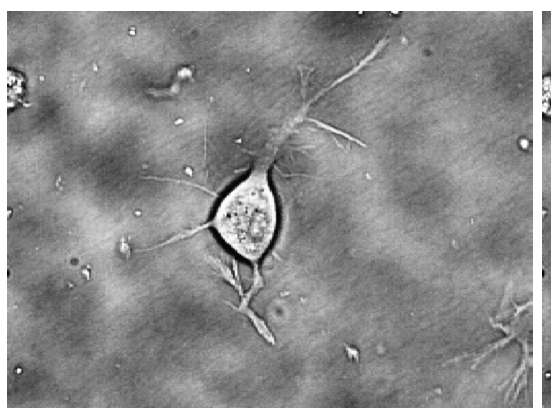

(g)

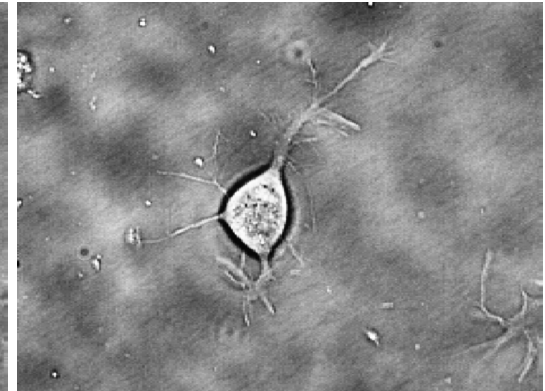

(b)

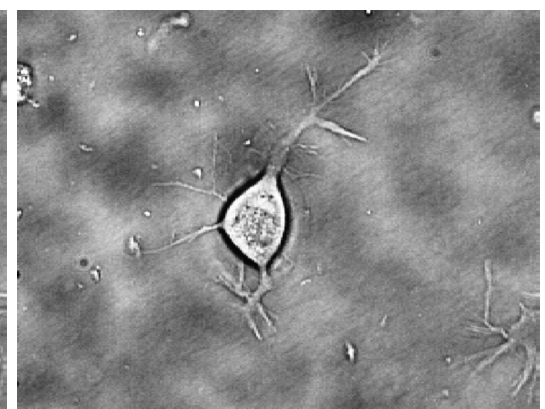

(d)

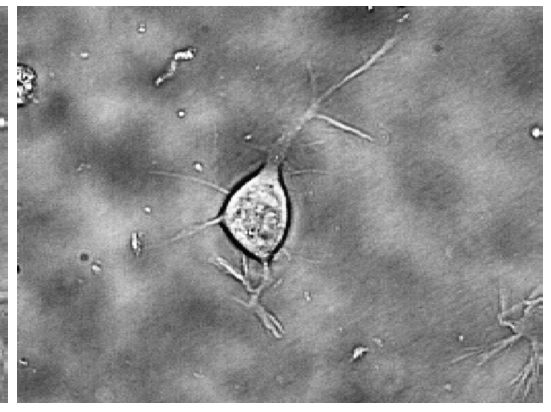

(f)

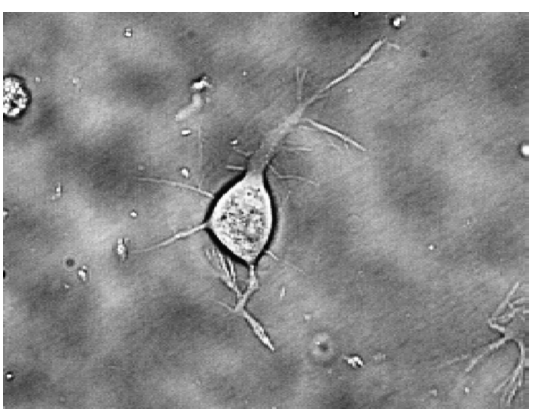

(h) 


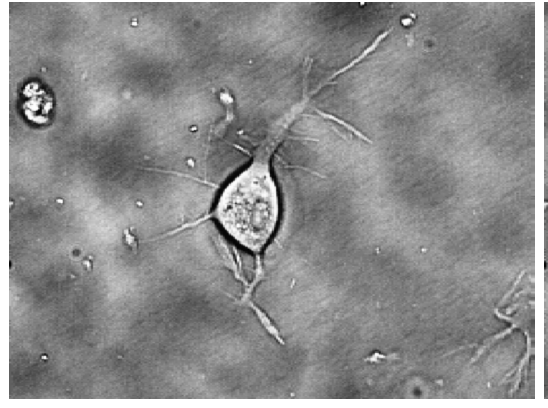

(i)

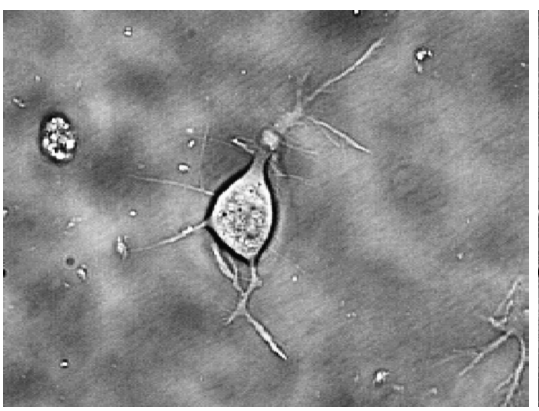

$(\mathrm{k})$

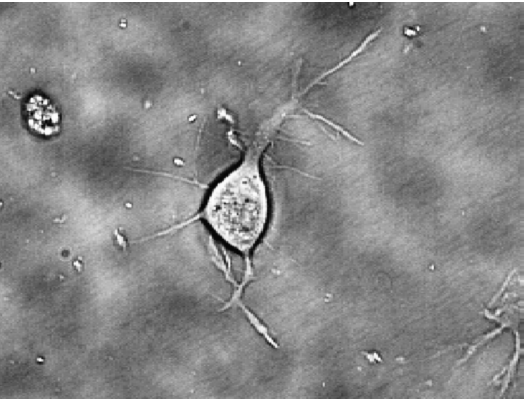

(j)

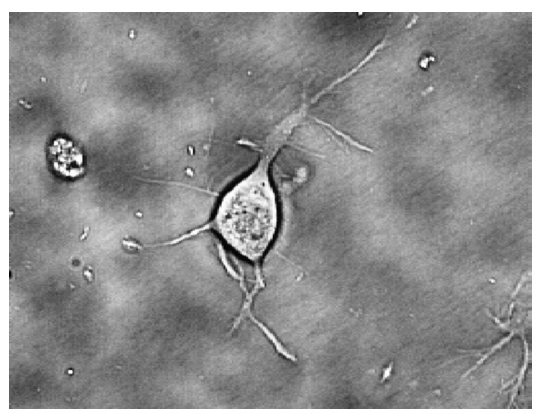

(1)

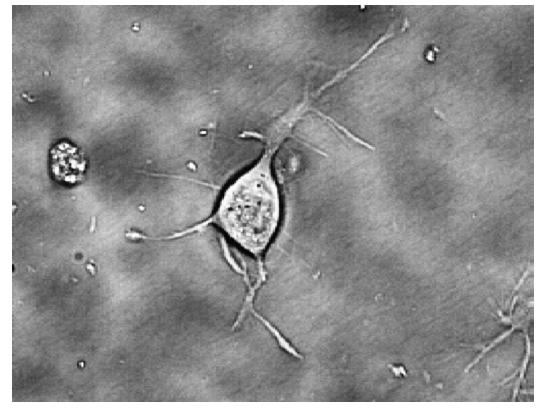

(m)

Figura 17 - Sequiência de imagens durante a cultura de células.

Nas Figuras 16 e 17 observamos claramente que à medida que o tempo de aquisição da imagem aumenta ocorre um aumento no comprimento e/ou mudança de direção de algumas ramificações. Tal fato é observado tanto para as figuras que possuem um grande intervalo de tempo entre uma imagem e a seguinte, Figura 16, quanto para as imagens cujo tempo de aquisição eram menores, Figura 17. Também é interessante notar que a modificação nos neurônios ocorre sempre ou nas extremidades das ramificações, ou em uma região com algum tipo de protuberância, evidenciando uma certa localidade aos processos de crescimento. Portanto, não é muito comum encontrarmos modificações que atuem globalmente nas células, quando acontecem é apenas por um curto período de tempo. A característica de 
eventos localizados foi levada em consideração no modelo de crescimento neural proposto apresentado no Capítulo 6, onde a velocidade de crescimento foi tomada como localizada e proporcional a curvatura.

\subsubsection{Segmentação de seqüências de imagens}

Uma vez obtidas as imagens, o processo de análise do crescimento e extração de medidas envolve várias etapas. A primeira delas consiste na extração das bordas das células, pois iremos nos deter nos contornos celulares. A segmentação é um problema muito estudado em processamento de imagens e existem diversas técnicas voltadas para a sua solução. Contudo, nenhuma delas apresenta bons resultados quando as imagens investigadas apresentam diferentes condições de iluminação [Castleman(1996), Costa(2000)]. No nosso caso, além das imagens apresentarem ruído de iluminação do ambiente, elas ainda apresentam células que são transparentes à passagem de luz. Desse modo, fica praticamente impossível extrair resultados confiáveis dessas imagens através da utilização de filtros lineares padrão para a detecção de suas bordas, conforme descrito na literatura [Gonzalez(1987), Castleman(1996) e Costa(2000)]. Para solucionar esse problema optamos por realizar a extração de bordas de forma semi-automática. Esse procedimento é extremamente útil pois correlaciona a técnica computacional empregada a um dos sistemas de detecção de bordas mais eficaz que existe: o olho humano. Apesar do olho humano conseguir trabalhar sob diferentes condições de iluminação, ele pode apresentar subjetividade dependendo da imagem. Através desse método foi possível extrair as bordas com grande precisão, mesmo na presença de fortes distorções e ruídos. A Figura 18(a) apresenta o exemplo de uma extração de contorno completamente automática usando o filtro de Sobel e (b) um resultado da segmentação assistida pelo olho humano. Podemos observar que existe uma grande diferença entre um resultado e outro, principalmente no que diz respeito a continuidade do contorno. 


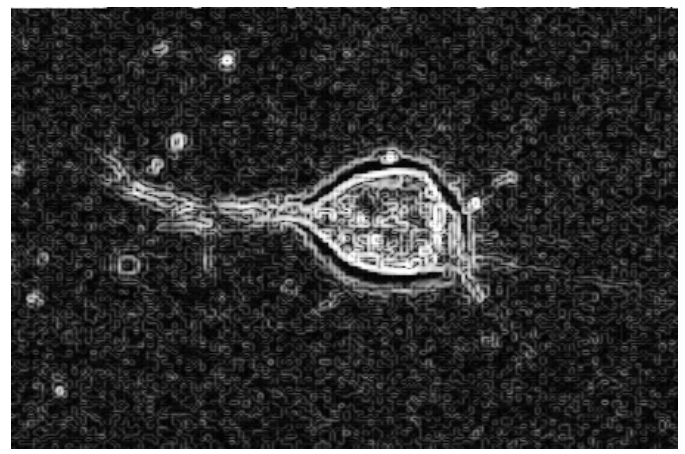

(a)

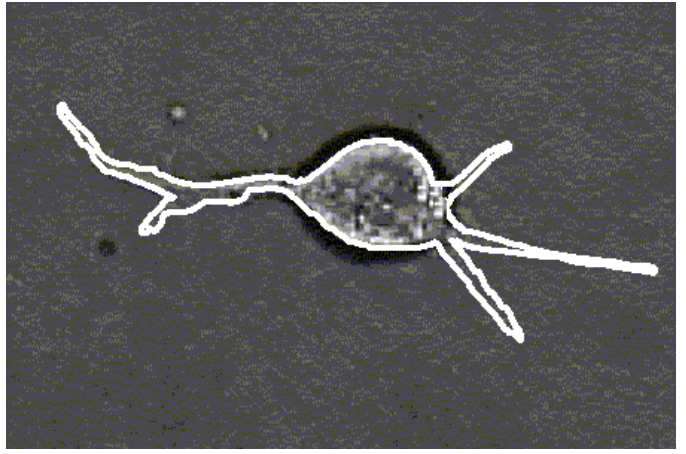

(b)

Figura 18 - Segmentação da Figura 16 usando o filtro de Sobel (a) e segmentação manual (b).

Em muitos dos casos de segmentação realizamos um processo combinado, utilizando primeiro a extração de bordas automática e melhorando esse resultado a partir da segmentação manual. A seguir descreveremos uma técnica que possibilita a determinação de correspondências entre dois contornos sucessivos. Essa técnica foi utilizada para a determinação de correspondências ao longo dos contornos obtidos das imagens de células neurais em crescimento, uma vez que essa informação era necessária aos modelos e hipóteses de crescimento propostos.

\subsubsection{Pontos de Controle e Correspondências}

Dados dois contornos $\vec{c}\left(s, t_{1}\right)$ e $\vec{c}\left(s, t_{2}\right)$ em dois instantes de tempo diferentes da seqüência de evolução (também denominada morphing), um assunto crítico é a determinação de pontos de controle nas imagens. Eles são porções individuais e importantes do contorno e que devem ser seguidos e analisados ao longo do processo. Além dos pontos de controle, devemos também determinar as correspondências entre esses pontos em instantes diferentes, de tal modo que a associação deva indicar onde um ponto na primeira curva foi mapeado ao longo da segunda curva. É importante notar que essas correspondências não são necessariamente um para um, pois pontos podem ser criados ou eliminados ao longo do crescimento da célula. Ela também não representa um processo simples, uma vez que envolve o conhecimento do processo de evolução que governa a dinâmica da curva, que é o objetivo do estudo. 
Existem diversas técnicas para a determinação desses dois fatores e essa escolha pode influenciar decisivamente no estudo das evoluções. Nesta tese, os pontos de controle foram identificados através de picos de curvatura (negativos ou positivos) ao longo de cada contorno da seqüência. O procedimento utilizado para o cálculo de curvatura é baseado no espectro de Fourier e em propriedades da derivada de Fourier, conforme descrito detalhadamente em [Cesar(1995)]. Buscando otimizar um método para a detecção dos pontos de controle e suas correspondências, desenvolvemos uma interface gráfica interativa, Figura 19, capaz de fornecer a detecção de picos de curvatura de forma semi-automática, pois permite ao humano adicionar e retirar pontos de controle quando necessário. A interface foi elaborada através do software Matlab e permite que o usuário extraia não somente o contorno das imagens, seus pontos de curvatura e suas correspondências, mas também avalie as hipóteses de crescimento na direção da normal, por convolução, na direção da curvatura.

Nessa interface as correspondências foram estabelecidas associando-se os pontos de curvatura que estão mais próximos. Inicialmente é feita uma pré-associação automática utilizando a menor distância euclidiana entre os contornos sucessivos. Esse resultado pode ser modificado manualmente através do programa se essa abordagem não gerar correspondências coerentes. Apesar da simplicidade do procedimento adotado, os resultados automáticos mostram-se muito eficientes, uma vez que as imagens não apresentam grandes modificações de um instante ao outro. No Capítulo seguinte iremos considerar o estudo das regras de evolução desses contornos de acordo com hipóteses de crescimento pré-definidos. Nos próximos itens iremos apresentar as medidas neuromorfométricas que foram obtidas e analisadas neste trabalho. 


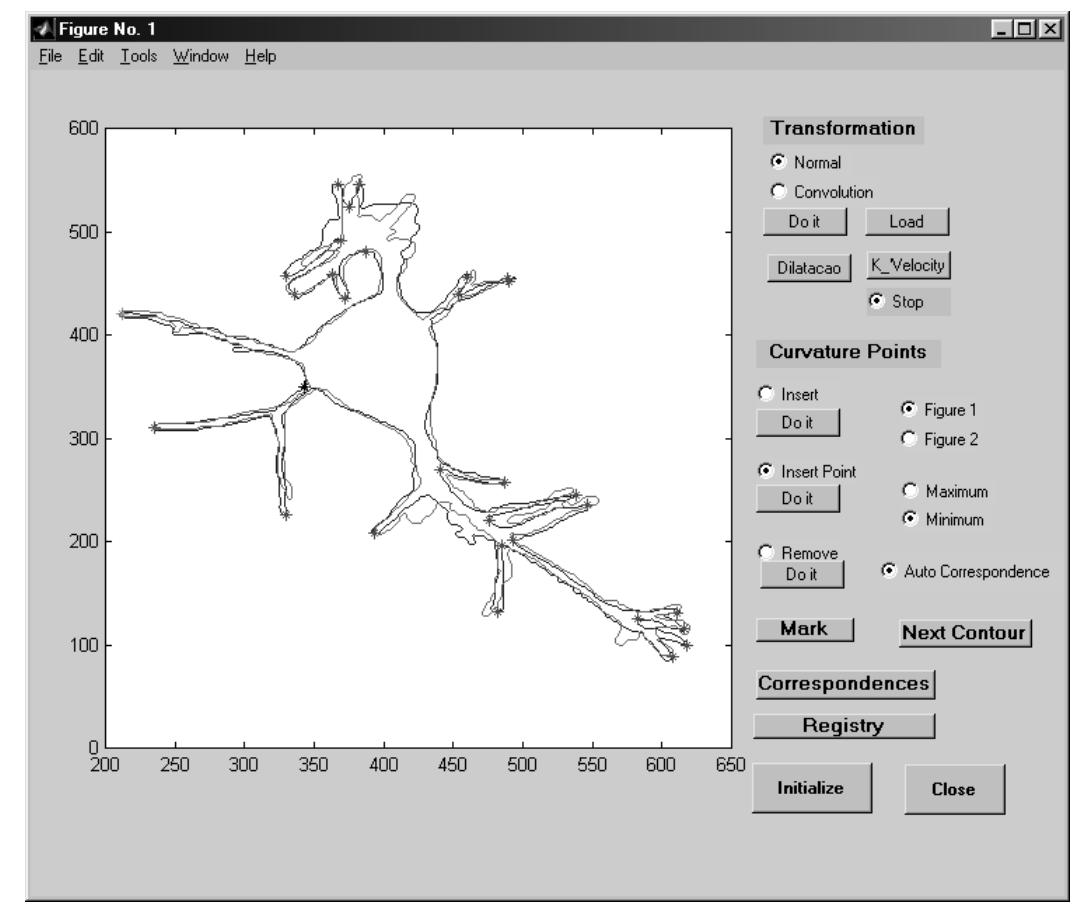

Figura 19 - Interface interativa do programa usado para definição dos pontos de controle e das correspondências entre as imagens da seqüência.

É importante ressaltar que o nosso grupo vem se destacando no desenvolvimento de técnicas de extração de de contornos (funções unidimensionais) através de figuras bidimensionais. As curvaturas são calculadas usando uma propriedade de derivada da Transformadas de Fourier [Cesar(1995)] de uma curva. Dentro desse contexto, a nossa motivação no estudo da curvatura vem do fato que ela tem se mostrado um importante atributo em descritores de formas, proporcionando, dentre outras características, a eliminação de redundância. Sendo assim, além da curvatura ser utilizada para a extração de pontos de controle, ela também será utilizada como um atributo de caracterização para as formas neurais e, principalmente, para a definição de regiões e velocidades de crescimento, como será discutido no Capítulo 6. Devido a sua importância, surgiu-nos a idéia de uma comparação mais quantitativa quanto ao valor da curvatura, comparando-a com diversas técnicas, em diversos tipos de imagens, sob a ação de diferentes quantizações da grade. Os resultados obtidos podem ser vistos em [Estrozi(1999), Estrozi(2003)], sendo que o principal resultado foi a robustez e a precisão da técnica desenvolvida por [Cesar(1995)] perante as outras técnicas, justificando a sua utilização, ao invés de outras. 


\subsection{Medidas Neuromorfométricas}

Nessa seção apresentaremos uma breve descrição sobre as medidas morfológicas extraídas das células, como obtê-las, e os resultados que elas podem gerar a partir de um conjunto de células.

\subsubsection{Esqueletização}

A esqueletização multiescala é uma técnica de representação de formas bidimensionais obtida através da transformada distância e da propagação de labels em uma imagem. A técnica é implementada em termos da dilatação exata [Costa(1999), Costa(1999)a e Costa(2000)] e consiste na produção de todas as possíveis dilatações de uma forma quantizada em uma grade ortogonal. Ela utiliza-se de uma estrutura de dados denominada SEDR - Sorted Exact Distance Representation que representa, sem omissões ou redundâncias, todas as distâncias possíveis na grade, até um raio máximo. O SEDR é indexado por um número inteiro representando a ordem no qual cada distância aparece e também guarda as coordenadas relativas de todos os pontos exibindo suas distâncias respectivas. A dilatação exata de uma forma digital pode ser imediatamente obtida colocando-se ' 1 ' nas posições relativas vazias definidas pelo SEDR para cada elemento da curva.

O esqueleto da imagem é obtido através de uma simples modificação no procedimento da dilatação exata. Ao invés de colocarmos o valor ' 1 ' em uma posição dilatada, colocamos o valor do seu respectivo rótulo (atribuição feita anteriormente a cada ponto do contorno). Esse processo é denominado de propagação de rótulos. Uma vez que possuímos a propagação dos rótulos, realizamos uma diferença simples entre os rótulos de um pixel e de seus quatro vizinhos. Nesse caso, o rótulo que possuir valor máximo e estiver acima de um limiar prédeterminado é considerado um ponto do esqueleto. Detalhes sobre a técnica de esqueletização e sua implementação podem ser obtidos na referência [Costa(1999) e Costa(1999)a].

É muito importante notar nesse algoritmo que a família de dilatações exatas geradas nas curvas para cada raio $R$ permite uma representação multiescala natural da forma original, com $R$ atuando como o parâmetro de escala espacial. Essa 
propriedade gera fenômenos interessantes e possibilita o desenvolvimento de novas medidas, tais como o fractal multiescala.

A partir do esqueleto de uma imagem fomos capazes de gerar dendogramas totalmente automáticos de células neurais. Os dendogramas são uma estrutura de dados que denota a organização hierárquica das ramificações dendríticas proporcionalmente e que armazena todas as informações referentes ao segmento dendrítico. Essa representação possibilita as extrações de medidas relacionadas aos ramos do neurônio, são elas: número de ramificações do neurônio, comprimento de ramificação, largura de ramificação, ângulo de ramificação, curvatura do segmento dendrítico e ordem das ramificações. Além disso, o próprio esqueleto da imagem possibilita a extração dessas medidas.

A Figura 20(a) apresenta uma imagem original de um neurônio, (b) uma representação tridimensional para o respectivo esqueleto multiescala, onde cada altura irá representar o esqueleto na respectiva escala, em (c) temos o esqueleto para uma escala específica, a escala 5 e em (d) o dendograma para a escala 5 , representação das hierarquias das ramificações.

A principal característica do esqueleto multiescala é a possibilidade de avaliação do esqueleto em diferentes níveis de detalhamento, o que até então não era possível. A variação da altura do corte na Figura 20(b) possibilita a geração de esqueletos com maior ou menor nível de detalhes, o que possibilita a representação do neurônio considerando diversos detalhes das suas ramificações. 


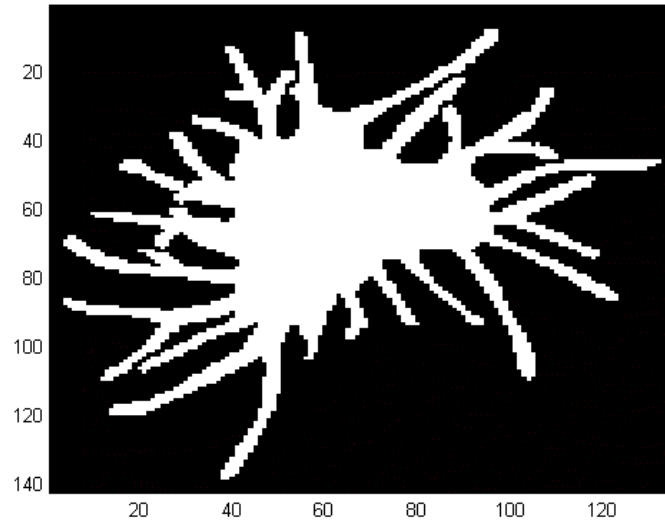

(a)

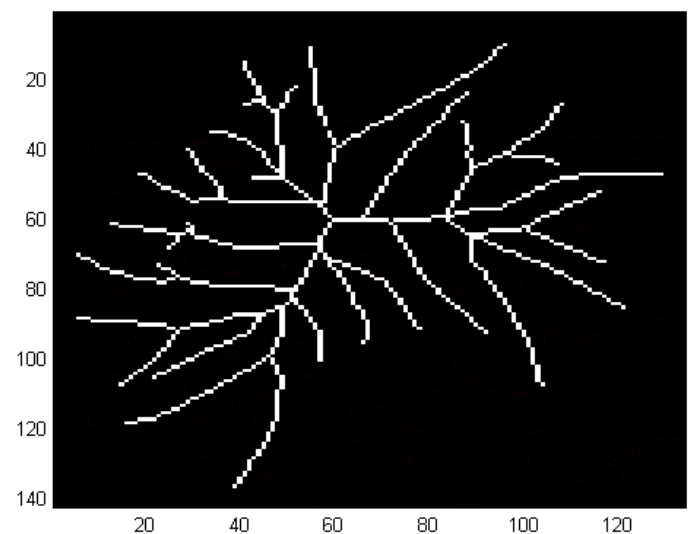

(c)

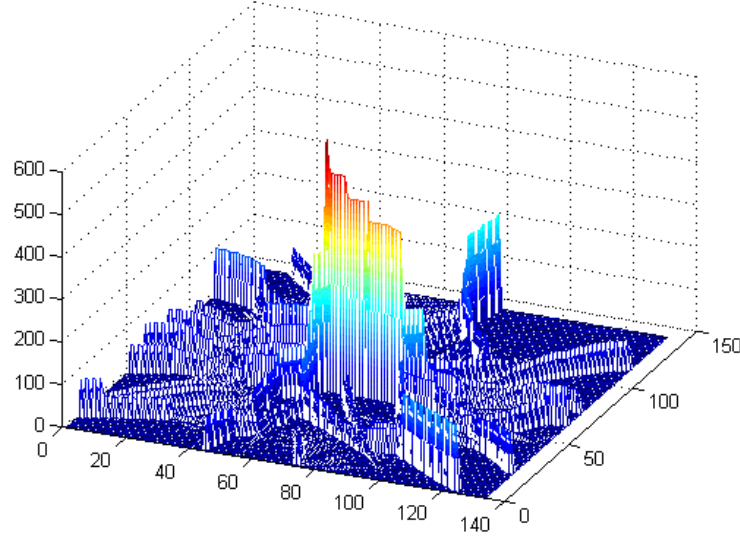

(b)

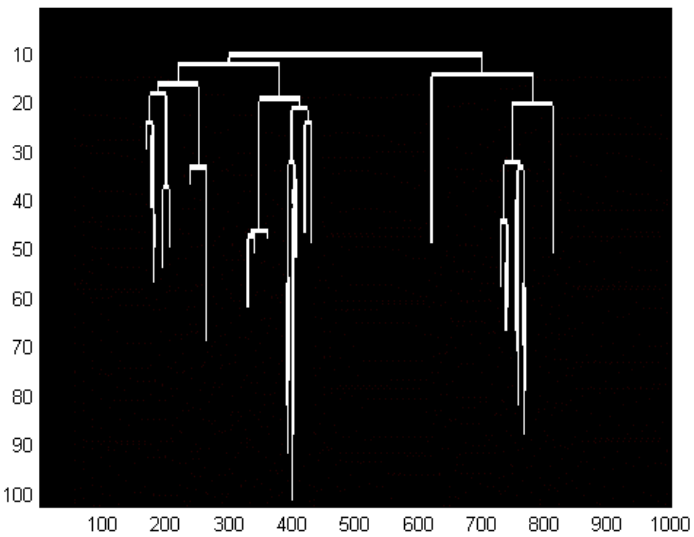

(d)

Figura 20 - (a) Imagem original do neurônio, (b) esqueleto multiescala, (c) o esqueleto para a escala 5 e (d) o dendograma para a mesma escala do esqueleto.

Esse trabalho apresenta os primeiros resultados de medidas celulares obtidos através do esqueleto multiescala. A Figura 21 apresenta vários gráficos de barras onde cada altura da barra representa o valor encontrado em função de uma ramificação específica, com exceção da medida de ângulo que é um histograma das distribuições dos valores de ângulo de ramificação. Os dados apresentados na Figura 21 foram extraídos de um único neurônio, cujo numero de ramos era 81 e possuía 13 hierarquias. O gráfico (a) representa os ângulos entre as ramificações do neurônio considerado, (b) os valores de curvatura para cada ramificação, (c) apresenta as larguras das ramificações, onde observamos que as larguras mais próximas ao soma são mais altas, e conforme as ramificações se distanciam do soma essa largura tende a diminuir, e em (d) apresentamos os valores de comprimento de cada segmento do neurônio, onde notamos uma grande diversidade entre os valores encontrados. 


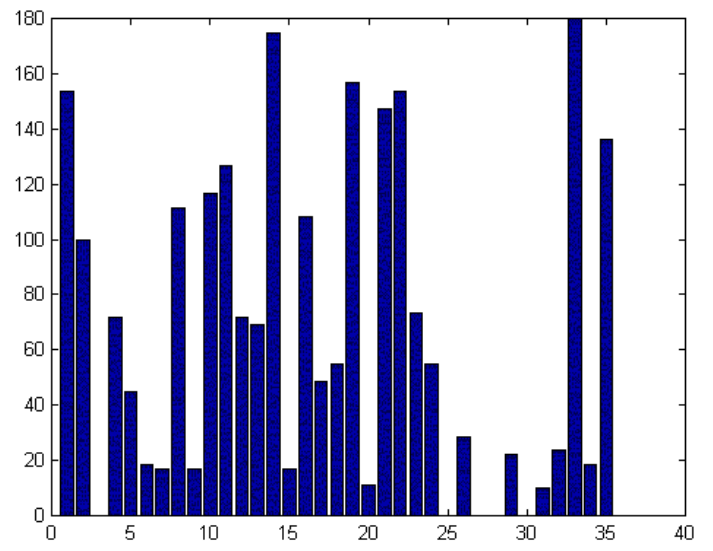

(a)

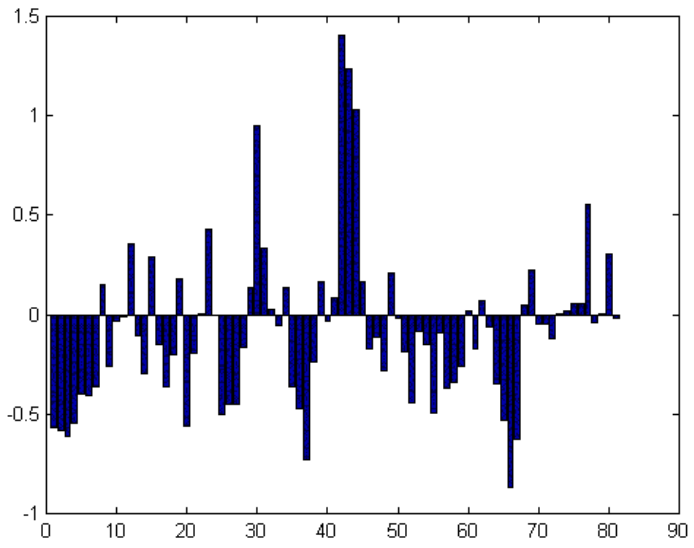

(b)

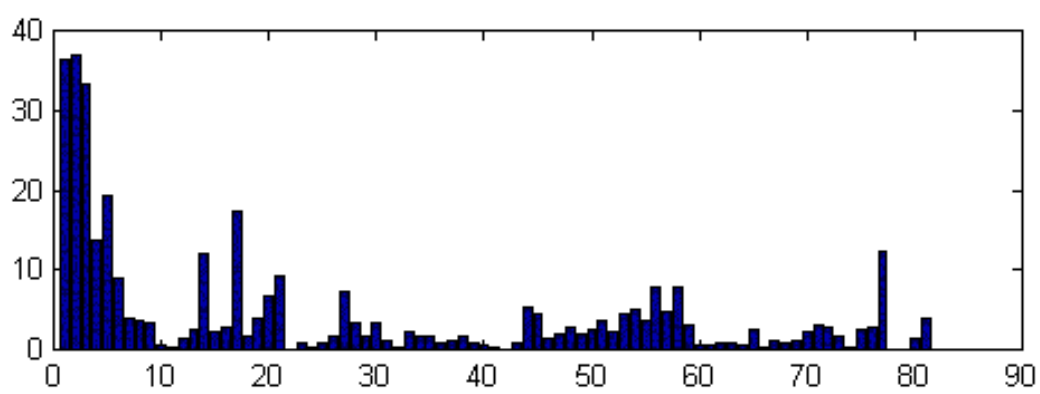

(c)

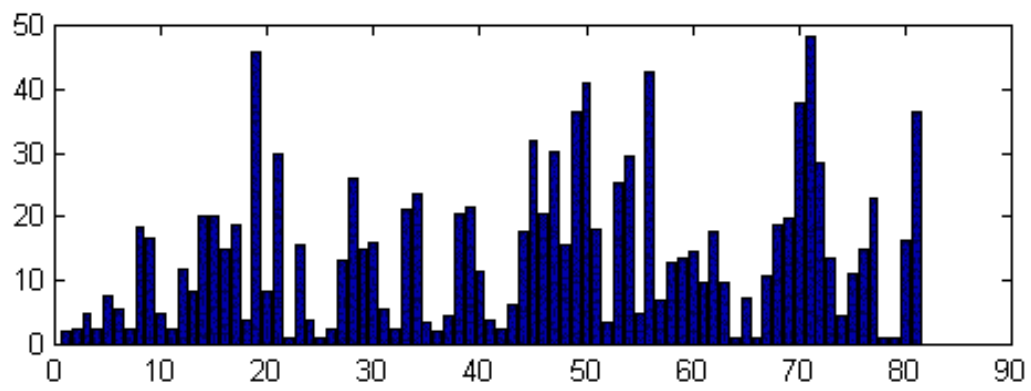

(d)

Figura 21 - (a) Histograma do ângulo inicial das ramificação, (b) valor de curvatura para cada ramo, (c) largura de cada ramo e (d) comprimento de cada ramificação.

Também foram feitos histogramas dos valores médios das medidas adquiridas para um conjunto de neurônios. Assim, possuímos gráficos de número de ramos e hierarquias. Estas representações, em geral, são feitas em forma de árvore e incluem comprimento e, eventualmente, espessura de cada galho representados por cada segmento do dendograma. A Figura 22 apresenta histogramas que caracterizam uma determinada classe de células neurais ganglionares da retina do Furão que encontram-se sem a ação de fator de crescimento, células CTR. Os histogramas 
representam a freqüência de ocorrência de um determinado valor da medida com relação a todas as células. Esses gráficos possibilitam que sejam encontrados valores de medidas entre as células que se repitam, ou seja, padrões que ocorram em todas elas. As medidas consideradas foram, respectivamente, o número de ramificações, o comprimento médio dos segmentos, a largura média dos segmentos, o ângulo nos pontos de ramificação, a curvatura média dos segmentos e a ordem dos segmentos dendríticos.
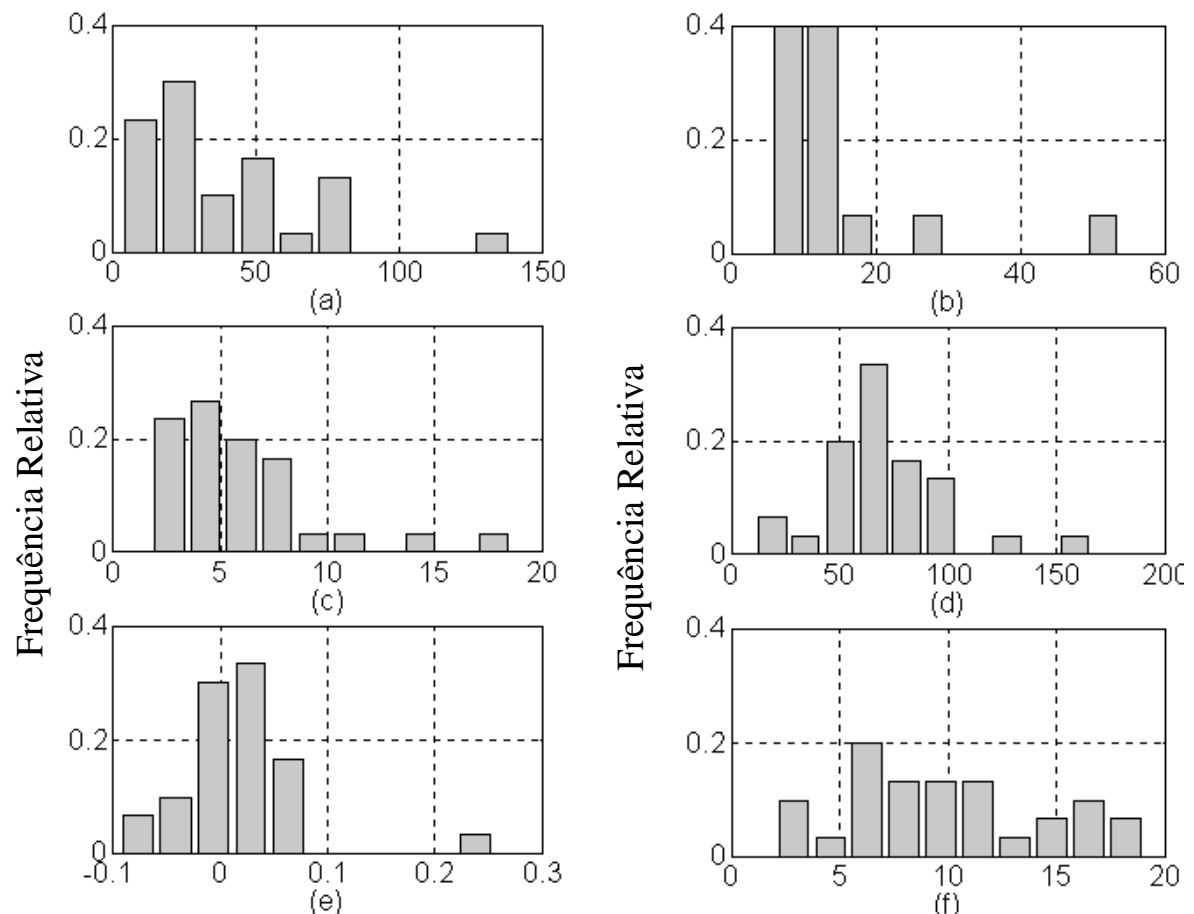

Figura 22 - Histogramas caracterizando o número de ramificações (a), comprimento médio dos ramos (b), largura média dos ramos (c), ângulos nos pontos de ramificação (d), curvatura média (e) e ordem máxima das ramificações (f) em pixels.

A partir da Figura 22 conseguirmos determinar alguns padrões entre as células de CTR. Em (a) aproximadamente $80 \%$ das ramificações possuem o número de ramificações menor que 50 pixels, em (b), quase a totalidade das células apresenta o comprimento médio menor abaixo de 20 pixels, em (c) a largura média dos ramos se concentrava ao redor de 5 pixels, em (d), os ângulos entre as ramificações estão concentrados entre $50^{\circ}$ e $100^{\circ}$, em (e) as curvaturas são caracterizadas como bem próximas de zero em muitos casos e, finalmente o item (e) apresenta uma grande dispersão entre os valores das ordens das ramificações. 
Podemos notar que a técnica de esqueletos aplicada a neurônios é uma ferramenta extremamente poderosa para a criação automática de dendogramas e de medidas celulares. É interessante comentar que grande parte dessas medidas são feitas manualmente nas células neurais pelos biólogos, um trabalho extremamente demorado e susceptível a erros, uma vez que os conjuntos de células geralmente considerados apresentam centenas de imagens. A geração de esqueletos e dendogramas automatizados permite um enorme ganho com relação ao tempo e também a precisão das medidas, tornando-se uma forte aliada à classificação de conjuntos de células neurais.

\subsubsection{Dimensão Fractal}

Em 1977, Mandelbrot introduziu o conceito de fractal como uma forma geral que é constituída de partes similares de um todo. De modo geral, um objeto é dito fractal quando ele possui "auto-similaridade infinita", ou seja, suas aparências são semelhantes qualquer que seja a escala espacial em que são observados. Além disso, Mandelbrot também propôs que o fractal fosse usado para caracterizar, explicar e modelar objetos complexos. Além da auto-similaridade, uma curva é definida como fractal se ela possuir duas variáveis que possam ser expressas por uma 'lei de potência', e seu perímetro seja infinito [Kraft(1995), Weisstein(1999)].

Na Figura 23 apresentamos um exemplo de uma figura fractal denominada curva de Koch [Kraft(1995)], onde podemos notar que cada pedaço da estrutura maior é análogo a estrutura menor (termo que se repete). Podemos imaginar que estamos visualizando a figura através de uma lupa com vários níveis de ampliação, e que independente de reduzirmos ou ampliarmos a imagem, continuamos a ver o mesmo objeto, onde a ampliação pode ser entendida como a escala de observação.

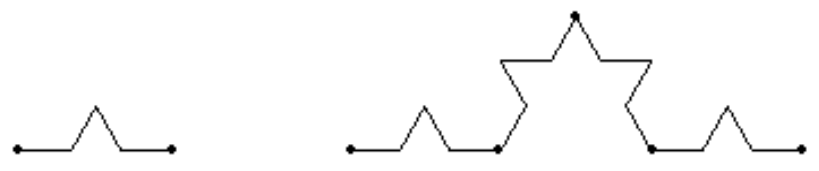

Figura 23 - Curva de Koch 
Existem diversas classes de fractais e sua classificação é feita de modo que se torne mais fácil entender os princípios que descrevem a sua natureza. São elas os fractais determinísticos (onde objetos abstratos são usados para expressar conceitos matemáticos) e os naturais (objetos que correspondem estatisticamente as características de fractal). Além dessas duas classes, ainda existem três tipos conhecidos de fractal: o fractal de superfície ou contorno (onde a superfície é invariante por uma mudança de escala), o fractal de massa (estrutura interna e a sua superfície são fractais), e o fractal de poro (estrutura do poro e a sua distribuição são fractais).

Visando uma análise das características do neurônio, o nosso maior interesse reside na dimensão fractal de um contorno, pois ela pode ser usada para caracterizar a tortuosidade e a complexidade de um contorno bidimensional. Ela é calculada em termos de uma relação $\log$-log entre alguma medida do contorno e a sua escala. Existem inúmeras técnicas utilizadas para estimar o cálculo da dimensão fractal do contorno [Coelho(1998)]. Um dos métodos numéricos computacionais mais conhecidos é o método de 'contagem de caixas', baseado no fracionamento do objeto em pequenas caixas [Coelho(1998)]. Entretanto, iremos nos deter na dimensão fractal usando salsichas de Minkowski [Coelho(1998)], devido a uma melhor precisão. Neste processo cada ponto do contorno é dilatado com círculos de raios $(r)$ crescentes, de modo que cada região dilatada é chamada de área da salsicha de Minkowski, $\mathrm{A}(r)$, onde $\mathrm{A}(r)$ segue a lei de potência dada na Eq. (29), e $D$ é o valor da dimensão fractal

$$
A(r) \propto r^{2-D}
$$

Na prática, geramos um gráfico em escala log-log das diversas áreas do contorno em função dos raios usados nas dilatações. O resultado é uma curva onde a região de maior fractalidade deve ser identificada e interpolada para uma reta. Nesse caso, o coeficiente linear $c$ da reta é determinado, e a dimensão fractal $(D)$ é dada pela Equação (30).

$$
D=2-c
$$


No caso de considerarmos figuras em um plano bidimensional, o valor da dimensão fractal é dado por (2-c). Porém se estivéssemos em um espaço tridimensional, o valor seria (3-c), conforme descrito por [Pinto(2001), Pinto(2001)a].

A dilatação do contorno em função dos raios dos círculos é feito utilizando a técnica de dilatação exata definida na Seção 5.3.1. Esse procedimento é realizado incorporando uma nova técnica para as salsichas de Minkowski e tornando o processo mais rápido e eficiente que o tradicional. Na Figura 24 apresentamos um exemplo de um contorno original e seu contorno dilatado sob a ação de diversos raios (raios iguais a 1, 3 e 5 pixels) em cada ponto do contorno.
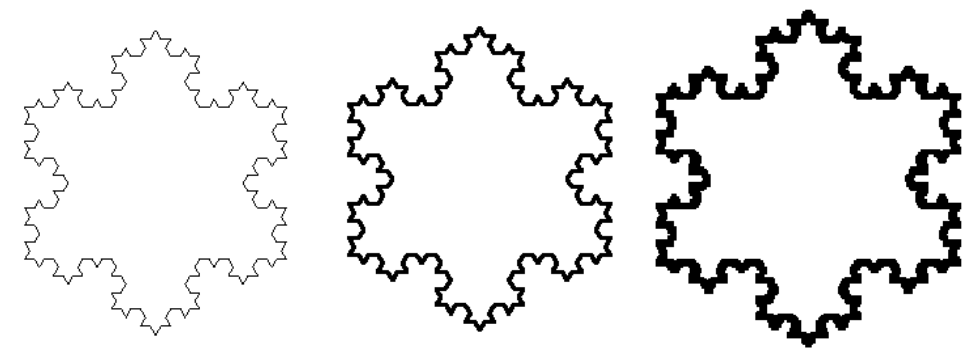

Figura 24 - Contorno original e imagens dilatadas com raios iguais a 3 e 5 pixels.

A análise fractal vem sendo muito utilizada pelos pesquisadores devido ao comportamento de leis de potência em muitos sistemas naturais. Sua maior motivação reside no fato de que a análise fractal aplicada a sistemas biológicos permite que os modelos desenvolvidos sejam mais completos e realistas. Além disso, vem sendo amplamente utilizado na caracterização de complexidade nos mais diversos ramos de pesquisa tais como, imagens de microscopia, células neurais, partículas, dentre outros.

O grande problema do uso indiscriminado da dimensão fractal é que as curvas fractais teóricas caracterizam-se por serem curvas indefinidamente fractais (autosimilares), e os objetos encontrados na natureza não apresentam esse comportamento, pois são finitos. Eles apresentam apenas regiões de fractalidade. Desse modo, temos apenas regiões onde podemos considerar que o elemento seja fractal, e o uso errôneo dessa análise pode gerar resultados distorcidos. Algo semelhante ocorre com as imagens digitais, que possuem resolução espacial limitada, impondo restrições adicionais à extensão do comportamento fractal dos objetos 
naturais representados nessas imagens. Portanto, o máximo que podemos esperar dessas análises é que essas formas apresentem dimensão fractal elevada ao longo de um intervalo limitado de escalas espaciais (raios de dilatação). Isso sugere que, para cada escala espacial empregada surja um valor específico para a dimensão fractal. Como ilustração, a Figura 25, mostra um exemplo da variação dos valores de dimensão fractal para alguns intervalos da curva $\log$ (área) vs $\log$ (raio). As retas em vermelho são as interpolações nos respectivos intervalos com seus valores de dimensão fractal.

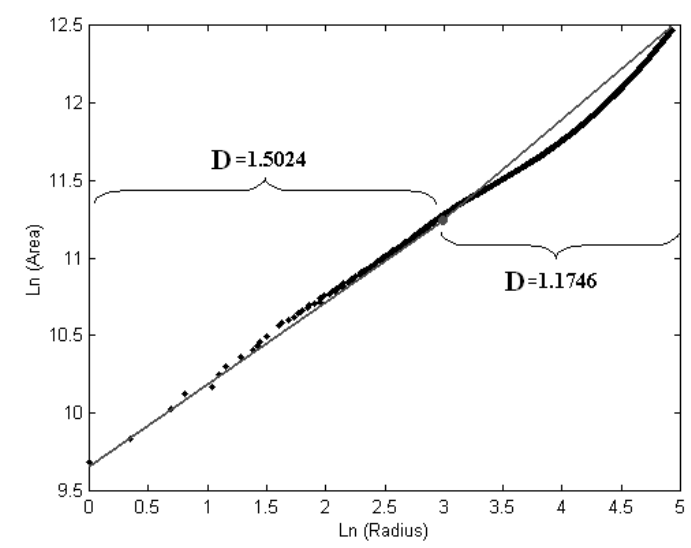

Figura 25 - Ilustração de uma curva de dimensão fractal da Quádrica mostrando variações do valor da dimensão fractal usando interpolação por retas.

O gráfico de extração da dimensão fractal através da interpolação linear, gráfico da Figura 25, apresenta uma grande variação entre seus valores, tornando o cálculo da dimensão fractal uma medida bastante subjetiva. Uma tentativa de melhorar essa medida foi proposta em [Coelho(1998)], onde era utilizado a interpolação por partes da curva de dimensão fractal. A proposta para eliminar a influência desse comportamento não fractal nas curvas foi a utilização da derivada da curva log-log. Nesse caso a derivada nos dá uma idéia pontual da variação da curva. Assim, tomando-se 2 - derivada da curva ( 2 - $d f / d x)$, obtemos uma curva de dimensão fractal e não apenas um único valor de dimensão fractal, ou seja, diversos valores ao longo da escala (raio de dilatação da salsicha), o que denominamos fractal multiescala [Costa(2001), Pinto(2001) e Pinto(2001)a].

Embora a derivada da curva seja facilmente obtida numericamente, ela apresenta um grande nível de ruído devido a não suavidade e a amostragem da curva, fato que 
não ocorre com as curvas analíticas devido a sua amostragem ilimitada. Procurando resolver esse problema, propomos como solução a convolução da função derivada com uma gaussiana de desvio padrão $\sigma$, de modo que, a presença da gaussiana serve como um fator de atenuação ao ruído da derivada da curva. Para realizarmos essa convolução, tomamos o cuidado de utilizar um valor do desvio padrão que suavize a curva, sem eliminar valores importantes da curva de derivada, de acordo com resultados de suavização gaussiana obtidos em [Estrozi(2003)].

Considerando $h(r)$ como a função que representa a curva log (área) vs log (raio), a sua diferenciação é dada pela propriedade da transformada de Fourier e apresentada na Eq. (31), onde $f$ é a freqüência, $G_{\sigma}(f)$ é a transformada de Fourier da função gaussiana de desvio $\sigma$. A curva de dimensão fractal é obtida fazendo $2-d h(r) / d r$.

$$
\frac{d h(r)}{d r}=\mathfrak{I}^{-1}\left\{\mathfrak{I}\{h(r)\} G_{\sigma}(f)(j 2 \pi f)\right\}
$$

Esse procedimento de extração da derivada da curva permite que tenhamos diferentes valores de dimensão fractal, gerando um comportamento multiescala onde a escala é o raio de dilatação. Outro fator muito importante a se destacar é que agora não obtemos apenas o valor da dimensão fractal, mas também qual o raio de dilatação para esse máximo valor de fractal e por quantas escalas esse valor consegue se manter (largura da curva de dimensão fractal) [Pinto(2001)].

A título de ilustração, a Figura 26(a) mostra a imagem da curva triádica de Koch, (b), a sua curva em escala $\log$-log da área vs o raio e (c) a sua curva de dimensão fractal, com o valor de dimensão fractal máximo mostrado por '*'. A curva apresenta um valor máximo encontrado para a dimensão fractal de 1,266 sendo que seu valor teórico é de aproximadamente 1,26. 

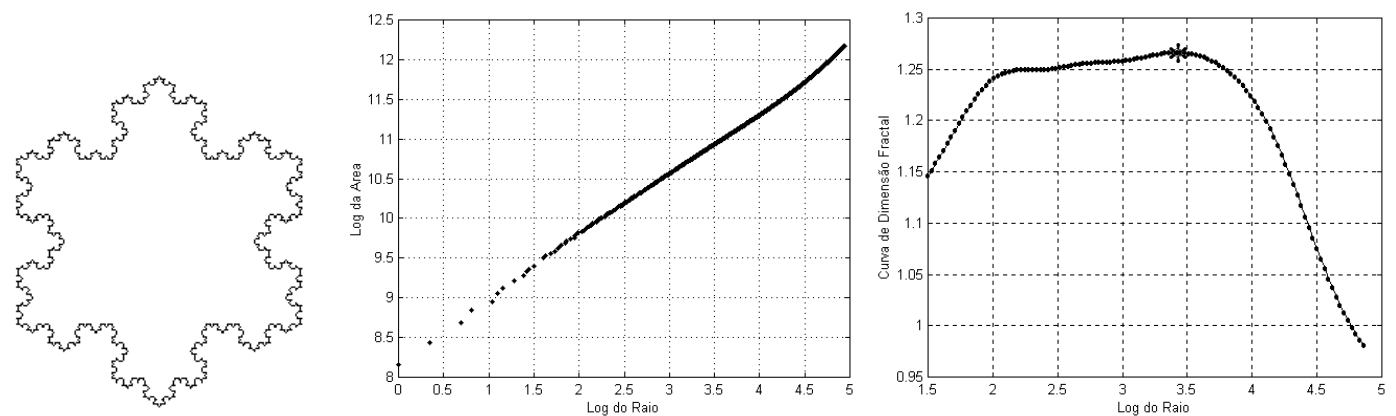

Figura 26 - Curva de Koch original em (a), log da área vs log do raio em (b) e curva de dimensão fractal em (c) $(2-d h(r) / d r)$.

Além da curva de Koch, realizamos o cálculo para outras curvas teóricas conhecidas, Quádrica com valor teórico igual a $\log (8) / \log (4)=1,50$ e calculado $1,504(\sigma=6)$, e Box cujo valor teórico é $\log (5) / \log (3) \cong 1,465$ e o calculado 1,465 $(\sigma=10)$. Como pode ser observado, os resultados encontrados para o valor máximo de dimensão fractal $\left(F_{\max }\right)$ em curvas teóricas ficaram muito próximos aos valores originais, indicando uma boa funcionalidade e precisão do método proposto. Esse pico de fractalidade pode nos indicar a complexidade de um objeto e tornar possível a comparação diversas formas.

Além do valor máximo, $\left(F_{\max }\right)$, a curva da dimensão fractal também determina a escala de maior fractalidade $\left(D_{\max }\right)$ e a largura desse pico de máxima fractalidade $(L)$, conforme ilustrados na Figura 27. No primeiro caso, a escala determina o tamanho dos detalhes apresentados no objeto, ou seja, quanto menor o valor da escala, menor o tamanho dos detalhes. Já a largura do pico de máxima fractalidade indica por quantas escalas (ou hierarquias) o objeto possui esse comportamento fractal.

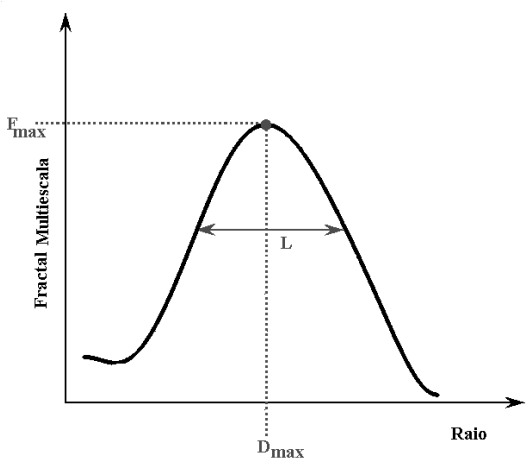

Figura 27 - Ilustração das medidas obtidas da curva de dimensão fractal [Costa(2002)]. 
Portanto, podemos destacar que ao considerarmos os três parâmetros de forma combinada $\left(F_{\max }, D_{\max } \mathrm{e} L\right)$, uma descrição mais completa é obtida a partir das curvas de dimensão fractal. Ao contrário das poucas informações obtidas dos métodos tradicionais.

\subsubsection{Dimensão Fractal de Células Neurais}

Uma das principais utilizações da medida de dimensão fractal é a extração de complexidade de objetos. Como a célula neural possui grande diversidade morfológica devido as suas ramificações dendríticas, resolvemos investigar sistematicamente essa medida nos dois conjuntos de células ganglionares do Furão, os conjuntos CTR e NT-4, Seção 5.1. No primeiro conjunto, as células eram cultivadas sem a utilização de nenhum fator de crescimento, situação denominada Control (CTR), e no segundo, sob a ação de neurotrofina, denominado NT-4.

As imagens tiveram as células segmentadas manualmente e sobre esse resultados realizamos a extração das medidas de dimensão fractal em um conjunto de 32 células Control e 9 NT-4. O objetivo desse trabalho foi buscar uma separação em classes dos grupos de células apresentados, de acordo com sua complexidade. Na literatura [Lasek(1986), Banker(1991), Levitan(1997) e Matus(2000)] existem evidências que a ação ou não da neurotrofina poderia modificar a incidência de ramificações na célula, ou seja, sua complexidade. Desse modo, os resultados mostrados a seguir tem por objetivo investigar essas evidências.

Além do máximo valor de dimensão fractal, outro parâmetro considerado foi o raio para qual acontece esse valor máximo de dimensão fractal, sugerindo uma determinação sobre a hierarquia das ramificações. A Figura 28, mostra alguns exemplos da curva de dimensão fractal para neurônios em $C T R$, itens (a) e (c), e NT4, itens (e) e (g), utilizando o procedimento de extração da derivada descrito no item anterior. Os valores encontrados para o máximo de dimensão fractal foram, respectivamente $1.31,1.28,1.23$ e 1.24 . A partir dos resultados podemos destacar que as células com $C T R$ apresentam um valor de dimensão fractal ligeiramente maior que os das células NT-4. Isso mostra que, embora os valores obtidos para todas as 4 células possuam um pequeno intervalo de variação, parece haver uma tendência em 
seus dados, que podem ser utilizadas para representar células cultivadas ou não com neurotrofinas.

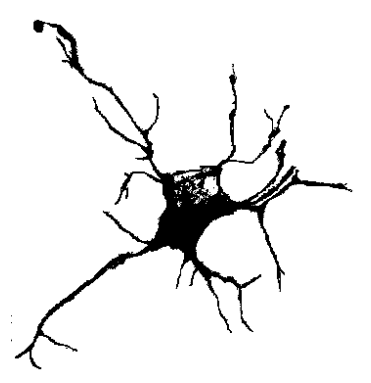

(a)

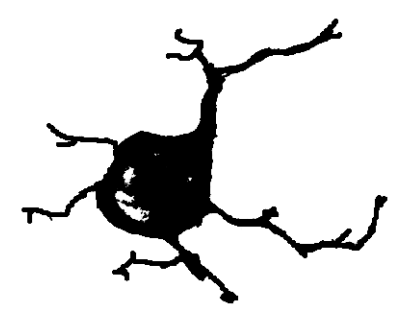

(c)

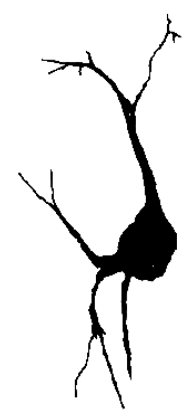

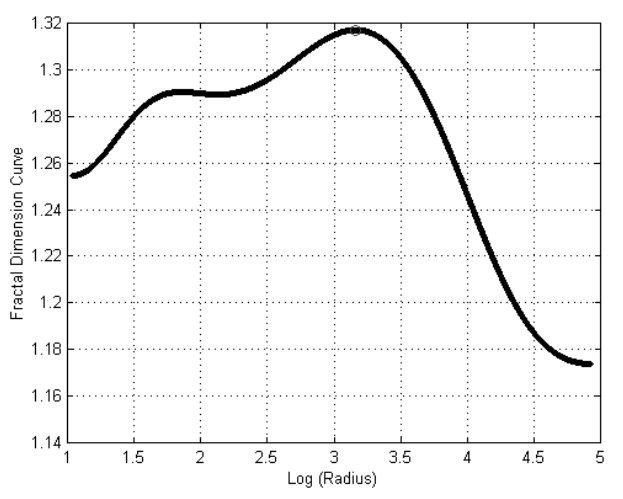

(b)

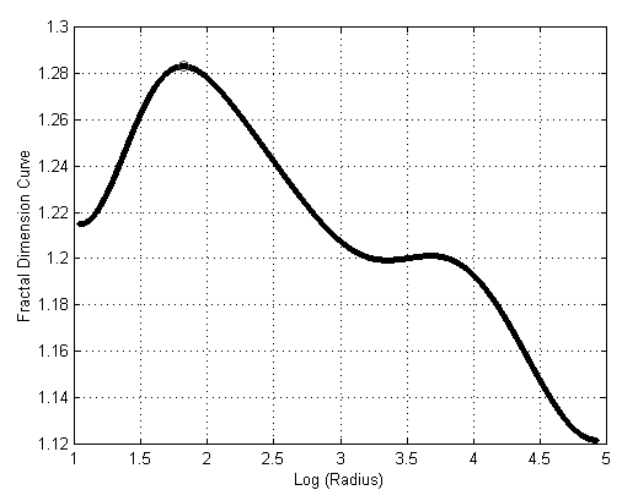

(d)

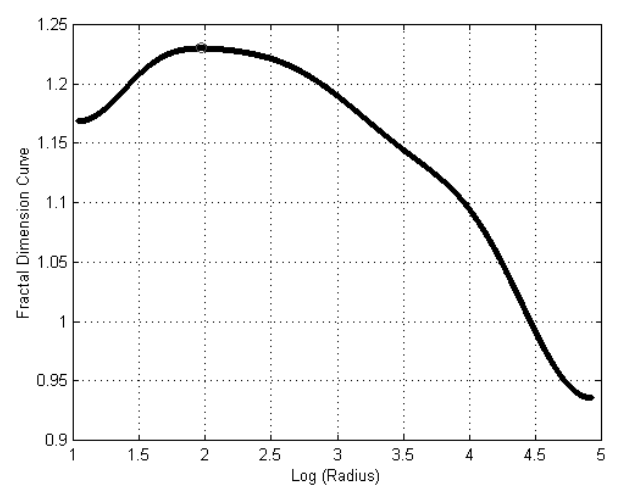

(f) 


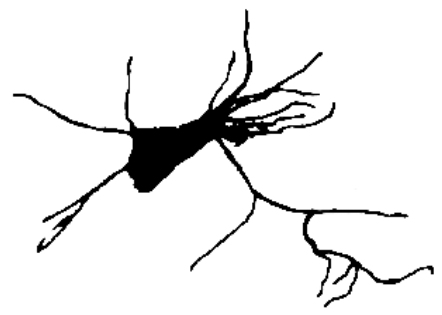

(g)

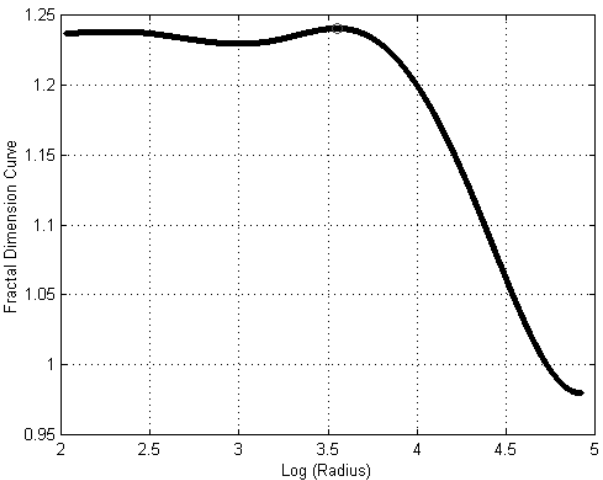

(h)

Figura 28 - Os itens (a) e (c) apresentam imagens de neurônios sob a ação de CONTROL e (e) e (g) sob a ação de NT4, e os itens (b), (d), (f) e (h) as suas respectivas curvas de dimensão fractal.

Para verificar se realmente essa diferenciação ocorre entre os valores de dimensão fractal para o uso da neurotrofina, calculamos os seus valores de dimensão fractal para todas as 41 células disponíveis. No gráfico da Figura 29 mostramos os valores máximos de dimensão fractal vs a escala que esse máximo valor ocorre (raio) tanto para as células sob a ação de $N T$-4 (em azul) quanto para a situação $C T R$ (em vermelho). A idéia é mostrar que essas duas medidas podem apresentar uma separação entre as classes para os dois tipos de células, entretanto isso não foi observado. Notamos que as posições dos pontos para os dois tipos de células ficam muito agrupadas entre si, não resultando em uma separação entre as classes. Isso mostra que a primeira hipótese, Figura 28, não é válida para essa classe de células.

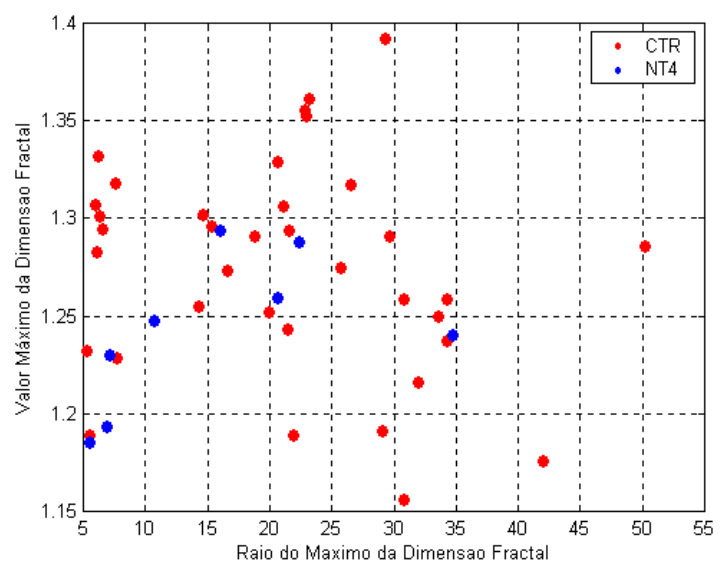

Figura 29 - Gráfico do valor da dimensão fractal vs o raio de dilatação que ocorre esse pico para as células em CTR (vermelho), e com NT-4 (azul). 
A Figura 30 mostra gráficos do valor de dimensão fractal em função do número de células, em (a), para os dois conjuntos de células, enquanto em (b) temos a escala para esse valor de dimensão fractal. O objetivo dessa análise era verificar se existia um limite de valores de dimensão fractal ou escala de uma classe de células para outra. Porém tal comportamento também não foi observado nesse conjunto de células, o que mostra que a hipótese inicial de que havia uma tendência a classificação usando dimensão fractal, não ocorre. Como resultado, verificamos que não existe um limite bem definido entre uma classe e outra. Portanto, a investigação apresentada para esse conjunto de células sugere que o valor de dimensão fractal e o seu respectivo raio de dilatação (escala) não foram suficientes para realizar uma separação em classes diferentes, de acordo com a ausência ou presença de fatores de crescimento. Desse modo, torna-se necessário a inclusão e investigação de outras medidas que possam ser mais eficientes. Outro fator importante que devemos salientar é que o conjunto de células utilizadas na classificação é ainda muito pequeno. O ideal seria considerar um conjunto muito mais representativo de células de cada classe para conseguirmos bons resultados na classificação.

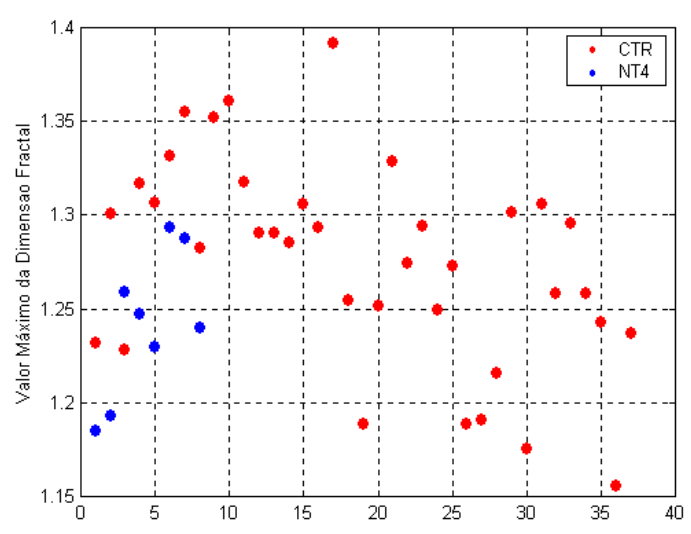

(a)

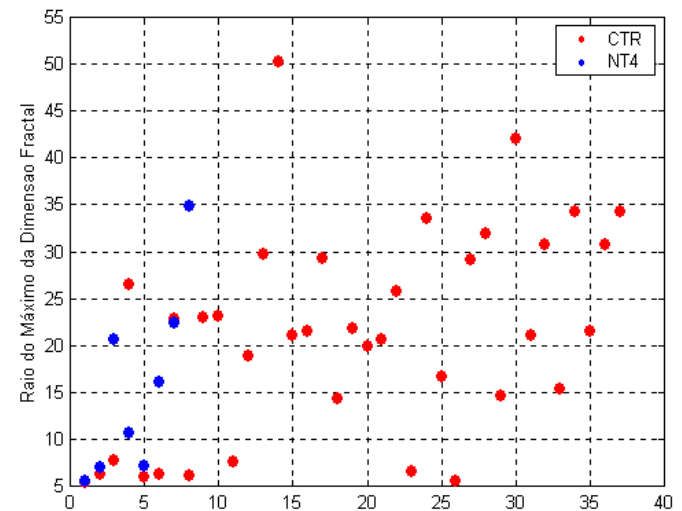

(b)

Figura 30 - Gráficos do valor de dimensão fractal (a), e da escala para esse valor de dimensão fractal(b). 


\subsection{Trajetórias}

Um aspecto muito importante que deve ser considerado no processo de evolução é a caracterização das propriedades da forma ao longo do seu processo de morphing. A análise desses parâmetros pode trazer informações sobre a forma, tais como preservação de informação, ou seja, se os instantes anteriores podem ser reconstruídos a partir dos posteriores. Desse modo, a construção de gráficos da evolução de características do contorno ao longo do tempo podem trazer informações interessantes sobre o processo de evolução. Esse gráfico envolve o mapeamento do estado da forma (um vetor no espaço de fase) considerando como variáveis de estado as coordenadas $x$ e $y$, parametrizadas ao longo do tempo definindo a trajetória da forma. No caso de um dos parâmetros escolhidos não variar ao longo do tempo, ele pode ser dito como estacionário, e caso contrário, como não estacionário. Além disso ele pode também ser caracterizado com estacionário e não estacionário no espaço, ou em ambas as situações tempo e espaço.

Os gráficos de trajetórias podem ser úteis na determinação dos comportamentos específicos da evolução, tais como descontinuidades e conservação das propriedades. As caracterizações podem ser feitas através da utilização de medidas globais da forma, tais como área, perímetro, dimensão fractal, raio de dilatação para máximo valor de dimensão fractal, energia de dobramento, dentre outras.

A Figura 31 apresenta a trajetória para a sequiência de imagens apresentada na Figura 17 considerando o perímetro das formas, o raio para o máximo valor da dimensão fractal e o valor de dimensão fractal máximo. A trajetória obtida a partir dessas medidas específicas produziu um gráfico localizado em algumas regiões, indicando que esses parâmetros não possuem uma variação tão grande ao longo do tempo. 


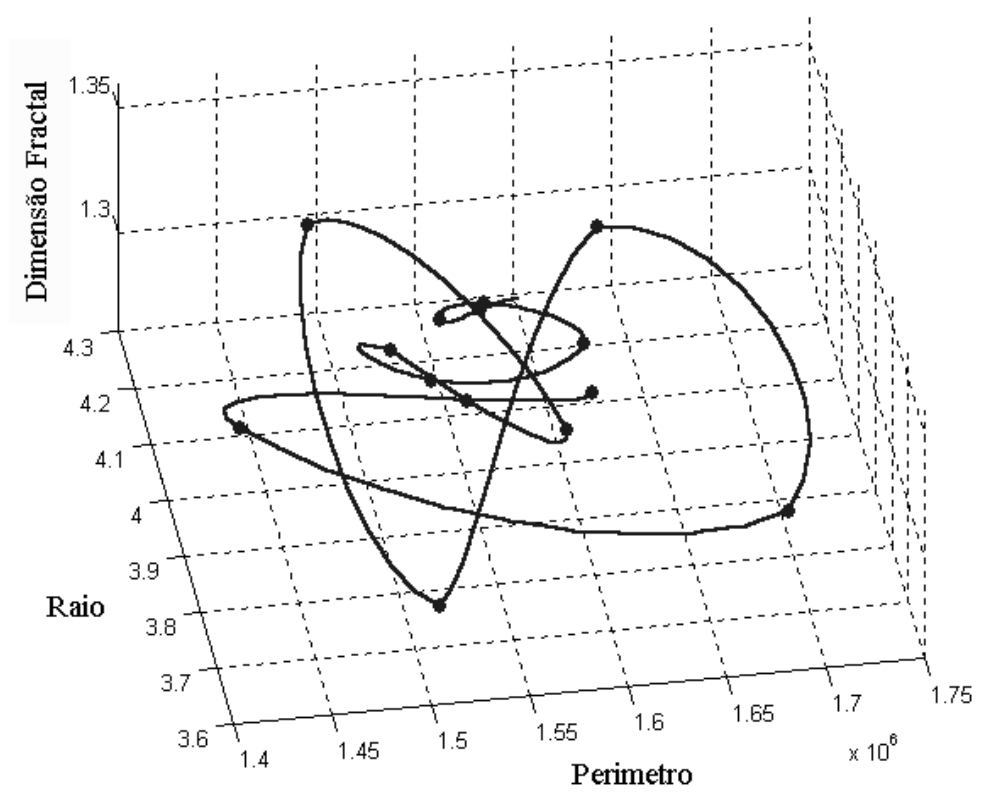

Figura 31- Gráfico da trajetória considerando a dimensão fractal, o raio para o máximo valor da dimensão fractal e o perímetro da sequiência da Figura 5. 


\section{CAPÍTULO 6: DESENVOLVIMENTOS E RESULTADOS}

Neste capítulo apresentamos o desenvolvimento e a simulação computacional de modelos de crescimento propostos para explicar a evolução de ramificações em estruturas semelhantes ao neurônio, e os resultados obtidos. Os modelos dividem-se em dois tipos: (i) os que são obtidos através de hipóteses sobre os tipos de transformações que atuam sobre uma forma, comparando os resultados com a evolução observada em células reais, e (ii) os de desenvolvimento baseados em contornos cujas regras são baseadas em características biológicas reais das células neurais.

A partir do estudo das transformações conseguimos descrever quais os tipos de evoluções biológicas possíveis, e procuramos intuir o tipo de modificação que cada transformação faz na forma e quais as transformações que estão ocorrendo no neurônio. Consideramos o crescimento ao longo da normal, por convolução, e por thin plate spline (minimização de energia). Os modelos de evolução de contornos foram baseados na formulação de contornos ativos, Snake Balloon, e na adição de restrições a sua formulação, que proporciona a ação do crescimento em função da curvatura, e também de um potencial externo. Podemos destacar os resultados obtidos no modelo de simulação neural, pois ele conseguiu gerar estruturas que possuem formas semelhantes aos neurônios reais. A seguir, apresentamos as hipóteses de evolução da célula neural e finalizamos o capítulo com a proposta para o modelo de crescimento e seus resultados.

\subsection{Evolução na Normal}

O modelo de evolução de superfícies através da normal é particularmente interessante em situações onde a forma é dilatada ou reduzida de forma uniforme, como, por exemplo, sob pressão interna. No caso da normal a forma evolui de modo análogo a uma frente de propagação [Sethian(1999)]. Nesse caso, a velocidade do 
contorno, em um certo instante $t$, é dada por $\dot{\vec{c}}(s, t)$ e é orientada ao longo da normal da superfície, como mostra a Eq. (32).

$$
\dot{\vec{c}}(s, t)=f(s, t) \vec{n}(s, t)
$$

onde $f(s, t)$ é uma função geral de $s$ e $t$ que corresponde à magnitude da velocidade. Quando $f(s, t)=a>0$, a forma dilata e se $a<0$ ela se contrai. Nesse caso, ambos os fenômenos ocorrem com velocidades constantes.

O procedimento para a investigação da evolução ao longo da normal consiste em verificar se em um instante específico a forma evoluiu ao longo da normal com respeito ao instante anterior. A hipótese é testada comparando-se o campo de velocidades de um par de imagens, com a normal do instante anterior. O processo ao longo da normal é constantemente verificado nas pontas das ramificações e dos axônios, e também pode ser caracterizado quando temos um aumento da área do neurônio. Uma vez obtidos os pontos de controle da forma na seqüência e suas correspondências, conforme especificado na Seção 5.1.2, a normal é obtida utilizando-se a propriedade da derivada no espaço de Fourier.

Como comentado anteriormente, os pontos de controle foram escolhidos como sendo os picos de curvatura da seqüência de contornos e as correspondências são determinadas supondo a Distância Euclidiana Mínima, ambos com intervenções humanas. Dada uma sequiência de imagens reais de uma célula neural em crescimento, a Figura 32 representa o teste da normal considerando dois instantes de tempo subseqüentes. Para uma melhor visualização, a sequiência é ampliada em um ramo específico da célula. No ponto de controle, em cinza, a velocidade é representada por vetores cinza e a normal por vetores pretos. 


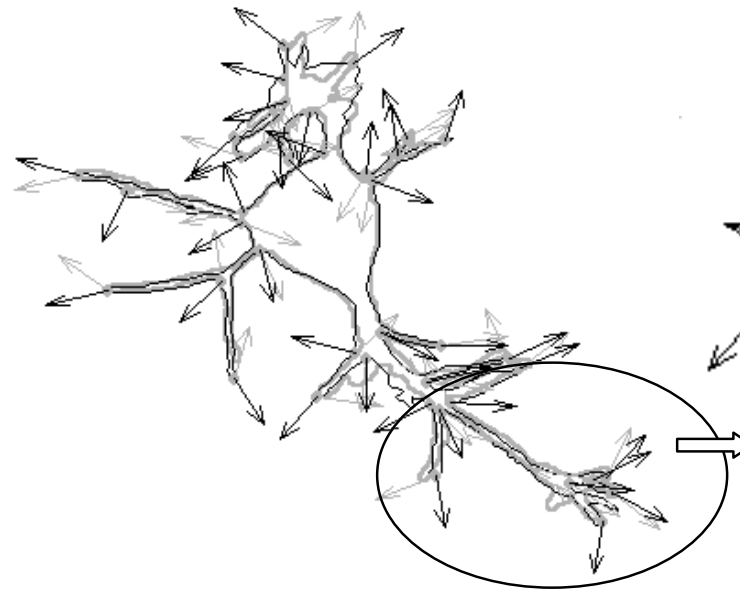

(a)

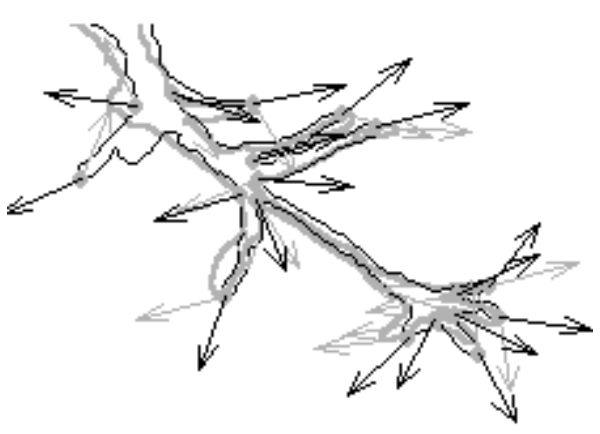

(c)

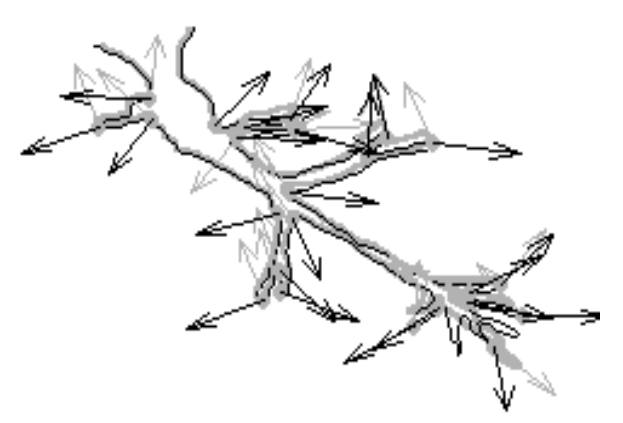

(e)

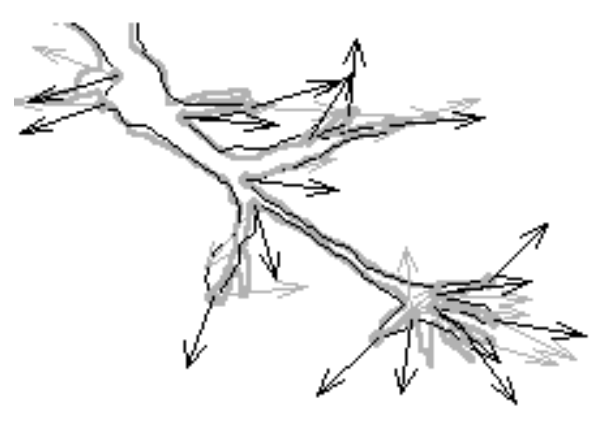

(d)

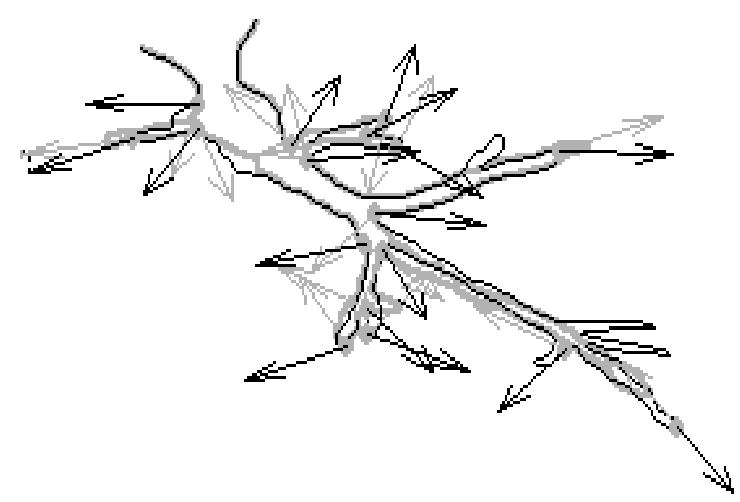

(f) 


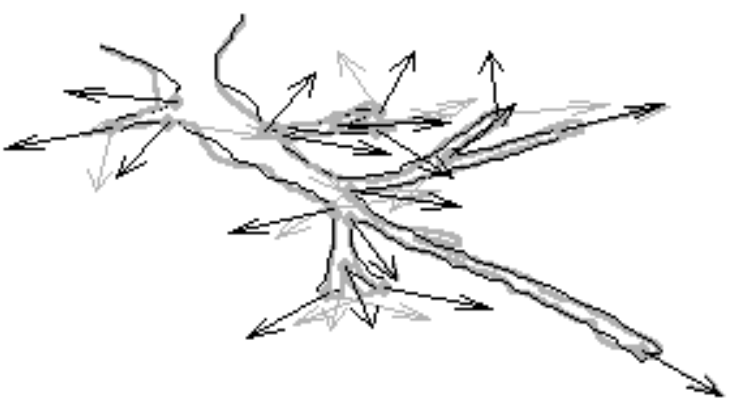

(g)

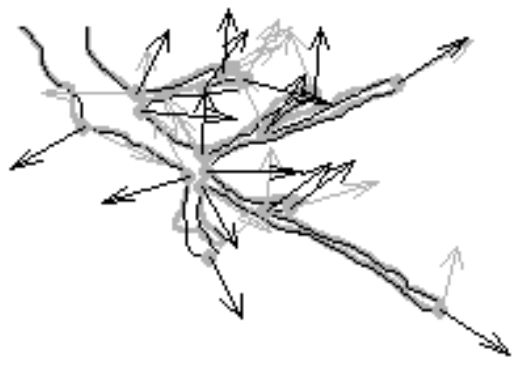

(i)

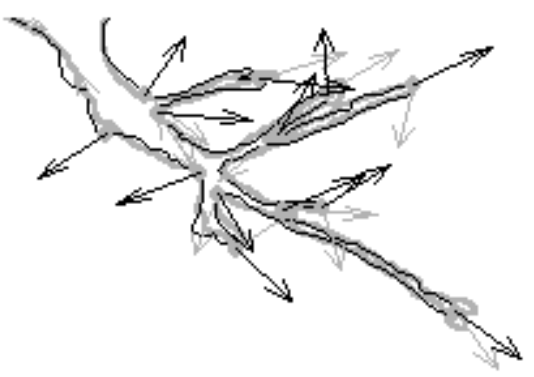

(k)

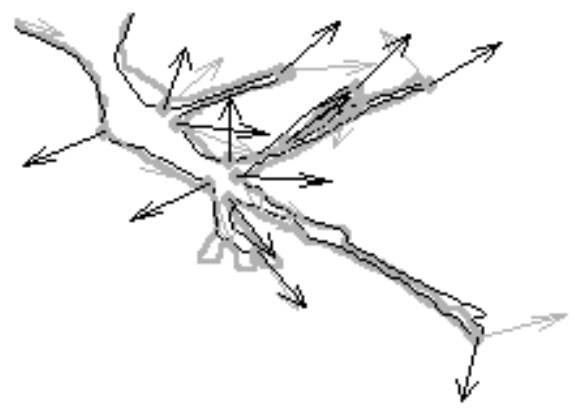

(m)

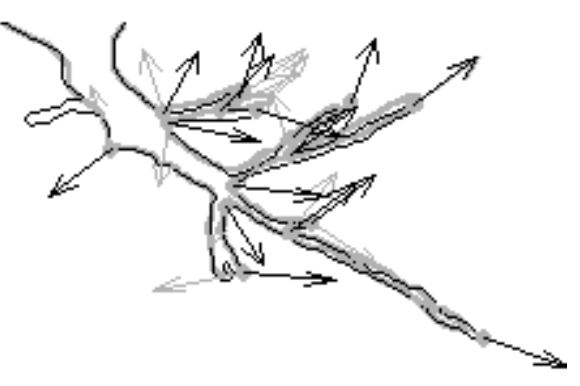

(h)

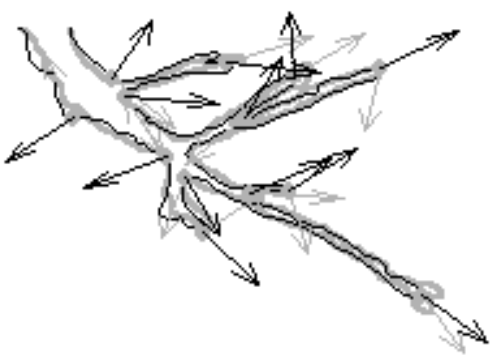

(j)

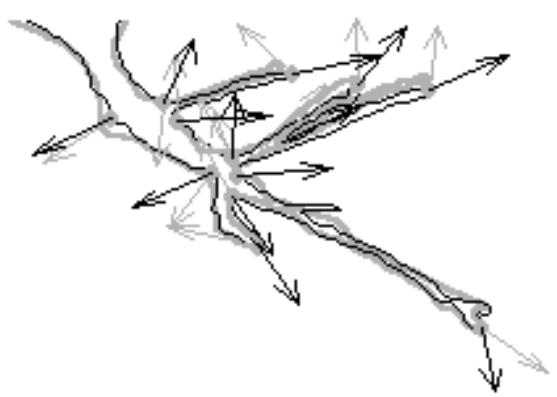

(1)

Figura 32 - Seqüiencia de uma forma neural em evolução, vetor velocidade (em cinza) e campo normal (em preto). 
A partir dos resultados dos vetores velocidade de evolução e normal da curva da Figura 32, geramos histogramas, Figura 33, com os valores dos ângulos entre os vetores velocidades e a normal para as curvaturas positivas, os pontos de terminação (a), e para as negativas, os pontos de ramificação (b). Também geramos um histograma do ângulo da velocidade com a horizontal (c). No caso da Figura 33 verificamos que os ângulos entre a velocidade e a normal encontram-se uniformemente distribuídos, chamando a atenção para o fato da evolução não se encontrar ao longo da normal (os ângulos seriam próximos a zero) para os pontos de controle considerados. Devemos salientar que os pontos de controle são obtidos através das altas curvaturas do contorno. Então, notamos que os locais de alta e baixa curvatura, que são, respectivamente, as extremidades e ramificações, não seguem regras de crescimento ao longo da normal.
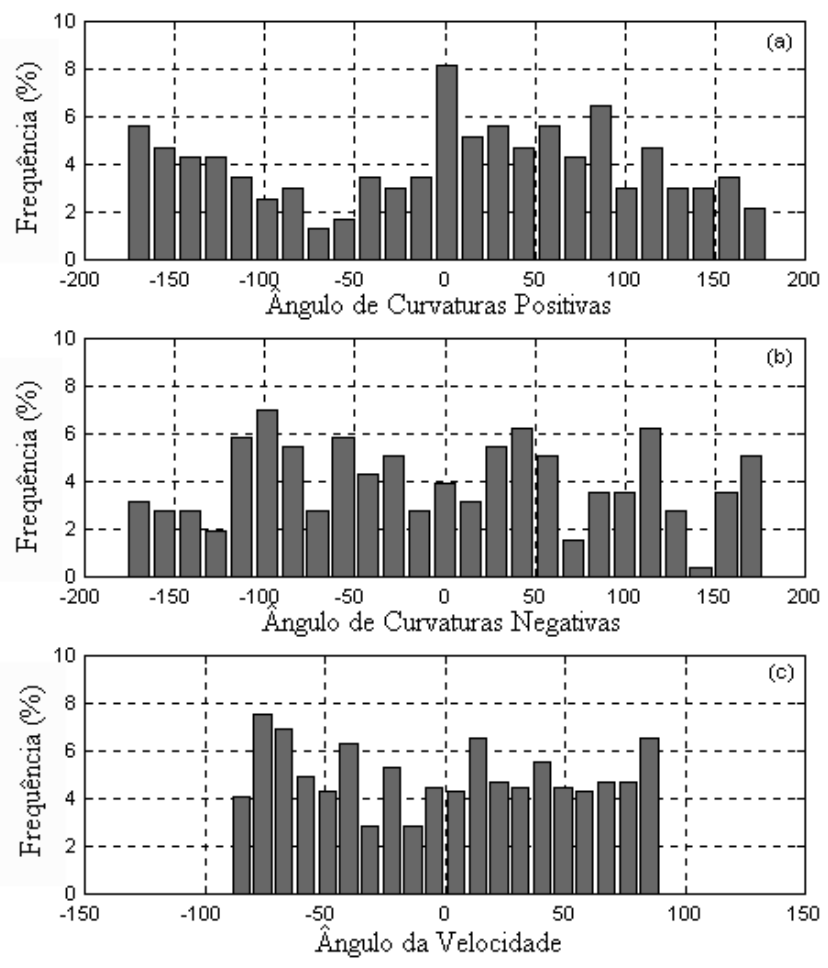

Figura 33- Histograma do ângulo entre a velocidade e a normal, para terminações (a), e ramificações em (b), e ângulo entre a velocidade e a horizontal (c). 


\subsection{Evolução por Convolução}

Existem situações onde a velocidade de evolução de uma forma é definida como uma combinação das propriedades físicas ao longo da vizinhança de cada forma, ou seja as variações são verificadas isoladamente e localmente ao longo da forma. Essas características descrevem um processo denominado convolutivo, que usualmente é observado em processos biológicos que não são constantes ao longo do espaço e do tempo, ou seja, quando algumas porções da forma são modificadas independentemente de outras. A expressão matemática que descreve esse processo de convolução é apresentada na Eq. (33)

$$
c_{x}(\xi, t+\Delta t)=\int_{0}^{L} c_{x}(\xi-s, t) h_{x}(\xi, s, t) d s
$$

onde $h_{x}(\xi, s, t)$ é o kernel(base) de convolução atuando sobre a vizinhança da posição do parâmetro $\xi$. No caso da convolução, o processo é tido como não estacionário pois são considerados diferentes núcleos (kernels) centrados em diferentes posições.

A Figura 34 apresenta um contorno inicial (a), com simulações de diferentes convoluções gaussianas conhecidas, filtro passa-baixa com 2 desvios padrões diferentes $(\sigma=4$ e 7), Figura 34(b). Os pontos em azul indicam o início e o fim da convolução para um determinado valor de $\sigma$.

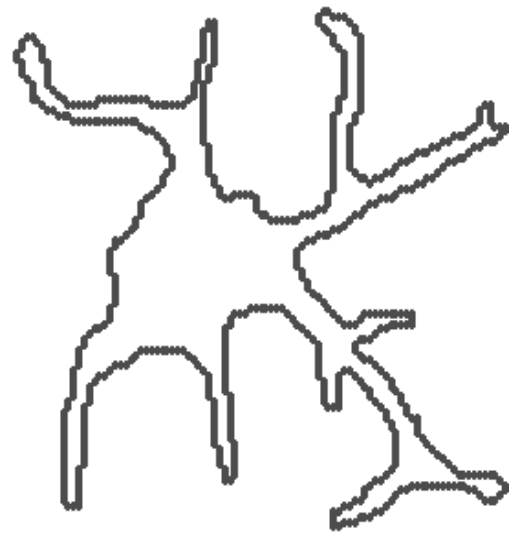

(a)

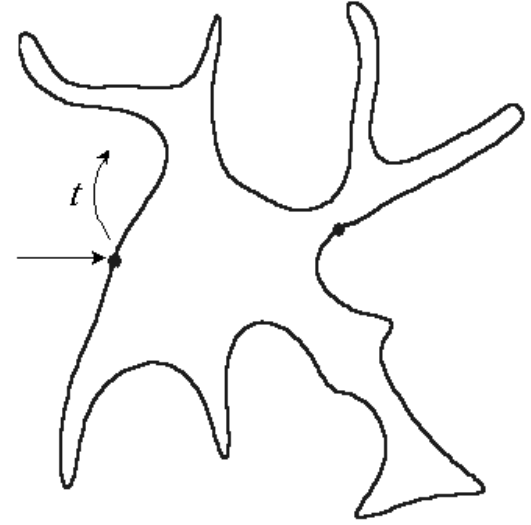

(b)

Figura 34 - Contorno original em (a) e contorno com aplicações de gaussianas em (b) . 
O procedimento utilizado para checar se um processo de mudança de forma corresponde a um modelo de convolução não estacionária consiste na obtenção de um sistema de equações lineares definidos pelo produto interno entre os kernels (ou seja, as incógnitas) e o contorno da forma. Os kernels são tomados como tendo extensão $L$ de cada lado da posição considerada da curva, onde cada um deles é aplicada em $Q$ pontos em ambos os lados da curva, resultado em $2 Q+1$ equações para cada ponto do contorno e $2 L+1$ variáveis. Determinadas as equações, as bases das convoluções são estimadas aplicando a pseudo inversa [Jennings(1980)], com ridge regression para impedir instabilidades na função [Hoerl(1970)].

A Figura 35 apresenta os resultados obtidos para a estimativa do núcleo de convolução em determinadas porções da curva na Figura 34(b). Podemos notar um bom resultado na estimativa do núcleo de convolução (curvas em vermelho) no caso dessa simulações. O ruído apresentado deve-se ao fato de estarmos em regiões próximas a transição da convolução. Apesar dos resultados satisfatórios obtidos para a simulação, o método de convolução foi considerado pouco robusto em imagens reais, não apresentando bons resultados. O principal motivo para explicar esse efeito é a complexidade das imagens reais e a indefinição de regiões homogêneas ao longo das evoluções, dificultando a estimativa dos núcleos de convolução.

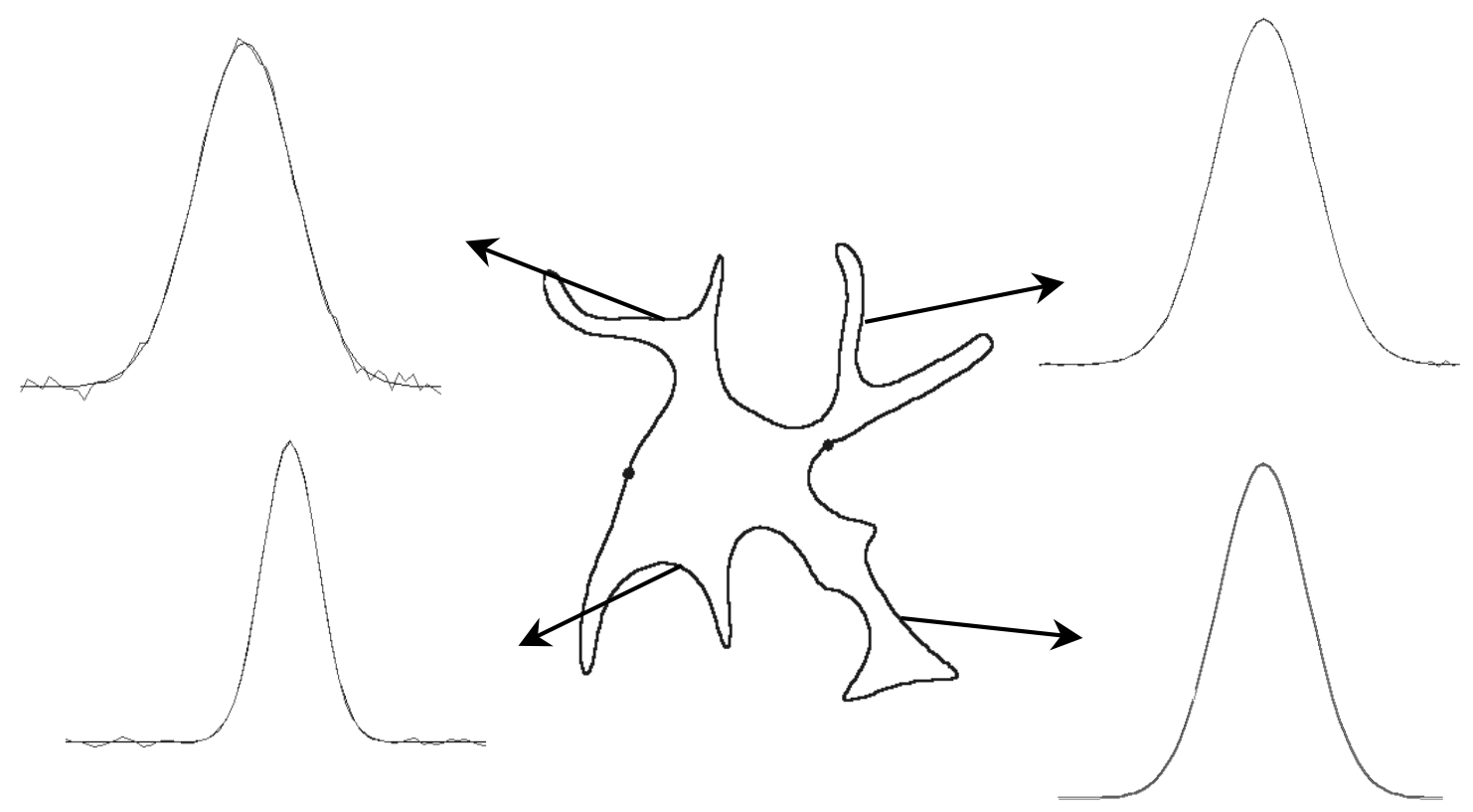

Figura 35 - Estimação dos núcleos de convolução, em azul temos as bases originais e em vermelhos as estimativas. 


\subsection{Evolução por Thin Plate}

A técnica de thin plate spline é muito utilizada para realizar aproximações em um conjunto de observações feitas sobre a qual necessita-se de um modelo específico. Ela utiliza funções de base radial, Eq. (34), introduzidas inicialmente por Powell e discutidas em [Consularo(2000)]. Um exemplo é apresentado na Figura 36.

$$
g(\rho)=\left\{\begin{array}{cc}
0 \quad \text { se } \rho=0 \\
\rho^{2} \log (\rho) \quad \rho \neq 0
\end{array}\right.
$$

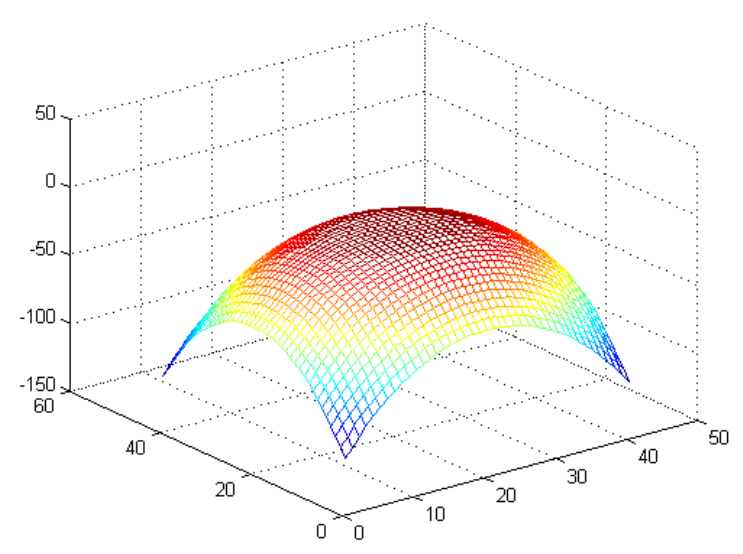

Figura 36 - Representação da função radial $-\mathrm{g}(\rho)$ utilizada na interpolação thin plate spline.

A interpolação usando as funções de base radial aproximam ou interpolam um conjunto de pontos aplicando uma base de funções escalares $g(\rho)$, no qual $\rho$ é uma norma sobre o espaço dos pontos conhecidos. Além disso a função é escolhida de acordo com um critério específico, como por exemplo, minimizar o valor da energia de dobramento da superfície, Eq. (35).

$$
E=\sum_{k=1}^{2} \int_{x=-\infty}^{\infty} \int_{y=-\infty}^{\infty}\left[\left(\frac{\partial^{2} \Psi_{k}}{\partial x^{2}}\right)+\left(\frac{\partial^{2} \Psi_{k}}{\partial x \partial y}\right)+\left(\frac{\partial^{2} \Psi_{k}}{\partial y^{2}}\right) d x d y\right]
$$

Uma vez escolhida a função base, a interpolação da thin plate spline, função bivariada $\psi(x, y)$, é definida usando a Eq. (36).

$$
\Psi(x, y)=a+b_{x} x+b_{y} y+\sum_{k=1}^{n} w_{k} g\left(\sqrt{\left(x-x_{k}\right)^{2}+\left(y-y_{k}\right)^{2}}\right)
$$


Logo a Eq. (36) pode ser representada na forma matricial, Eq. (37), onde $\vec{v}=\left[\begin{array}{ll}x & y\end{array}\right]^{\mathrm{T}}$.

$$
\Psi(\vec{v})=a+\vec{b}^{T} \vec{v}+W^{T} \vec{g}(\vec{v})
$$

Assim, dado um conjunto de pontos $\left(x_{k}, y_{k}\right)$ procuramos uma superfície $S\left(\left(x_{k}, y_{k}\right)\right)$ que interpole esses pontos e que minimize a energia de dobramento. Em [Consularo(2000), Costa(2000)] podemos encontrar mais detalhes sobre o método, sua implementação e alguns exemplos. A Figura 37 apresenta pontos em azul interpolados por uma superfície thin plate. Nesta figura pode ser observado uma boa concordância da superfícies com os pontos interpolados.

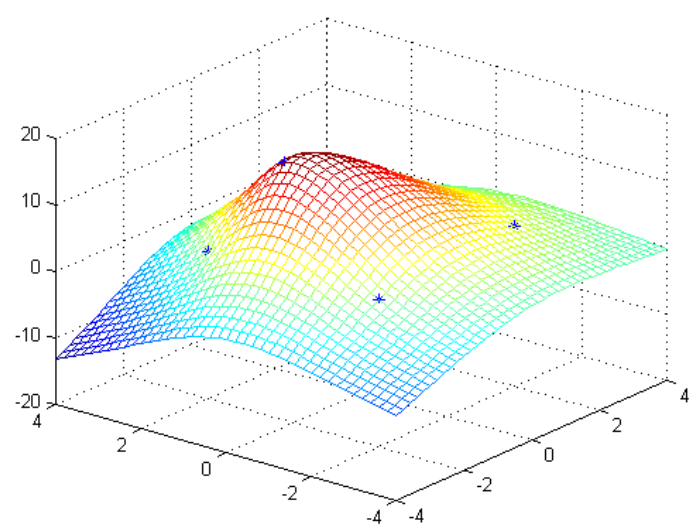

Figura 37 - Apresentação de uma superfície Thin Plate Spline para os pontos de controle marcados em azul.

Contudo, o nosso maior interesse no estudo de thin plate reside em pares de thin plate splines, pois elas possibilitam o estudo das transformações da forma de uma função inicial. Considere que temos uma função bivariada para cada coordenada $(x, y)$, Eqs. (38) e (39).

$$
\begin{aligned}
& \Psi_{x}(x, y)=a_{x}+b_{x, x} x+b_{x, y} y+\sum_{k=1}^{n} w_{x, k} g\left(\sqrt{\left(x-x_{k}\right)^{2}+\left(y-y_{k}\right)^{2}}\right) \\
& \Psi_{y}(x, y)=a_{y}+b_{y, x} x+b_{y, y} y+\sum_{k=1}^{n} w_{y, k} g\left(\sqrt{\left(x-x_{k}\right)^{2}+\left(y-y_{k}\right)^{2}}\right)
\end{aligned}
$$


que também podem ser rescritas na forma matricial, Eq. (40):

$$
\vec{\Psi}(\vec{v})=\vec{a}+\vec{B} \vec{v}+W^{T} \vec{g}(\vec{v})
$$

A implementação dos pares de thin plate splines pode ser obtida na referência [Costa(2000)], e pode ser utilizada na análise da movimentação das ramificações dendríticas em um neurônio, ou seja, através das thin plates. Dessa forma podemos calcular qual a energia de dobramento de um neurônio para sair de uma determinada forma e ir para outra. Podemos imaginar que esse tipo de parâmetro pode ser relacionado ao neurônio durante o seu crescimento, e, portanto podemos usá-lo como uma característica ao longo do crescimento. A título de comparação, as Figuras 38 e 39, apresentam alguns exemplos de simulações de modificações dendríticas simuladas em uma imagem de neurônio. Os pontos em azul representam o contorno inicial, e os pontos em vermelho representam o contorno após a simulação de crescimento em uma determinada ramificação. 


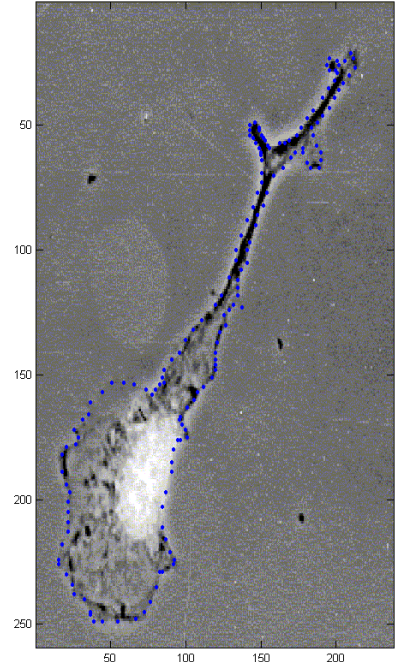

(a)

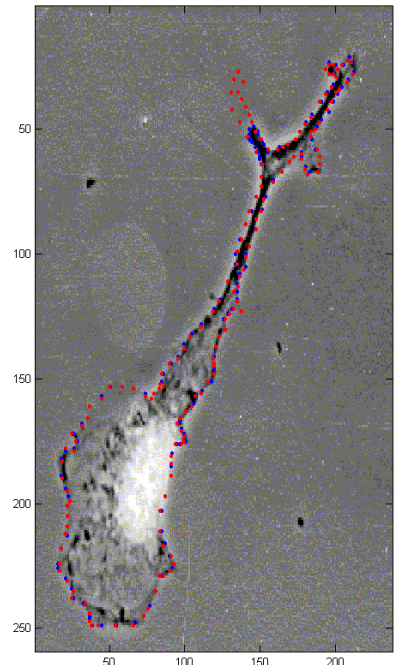

(b)

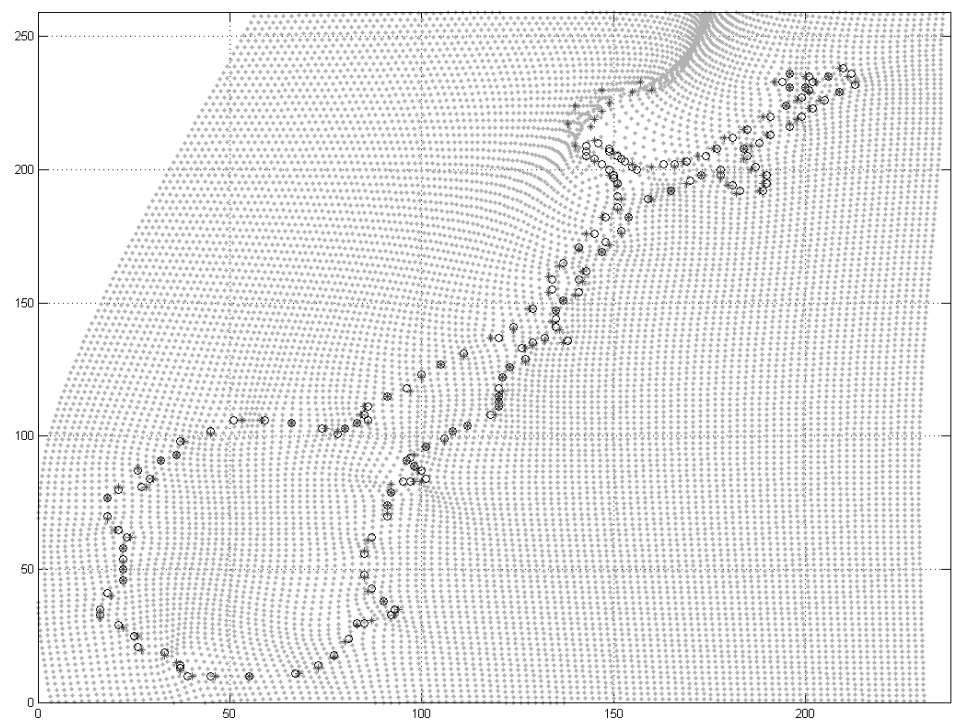

(c)

Figura 38 - Utilização de pares de thin plate na movimentação de um dendrito do neurônio.(a) imagem do neurônio sobrepostos com pontos de controle iniciais (azul), (b) imagem sobreposta com pontos modificados (vermelho) e (c) interpolação gerada a partir do pontos considerados. 


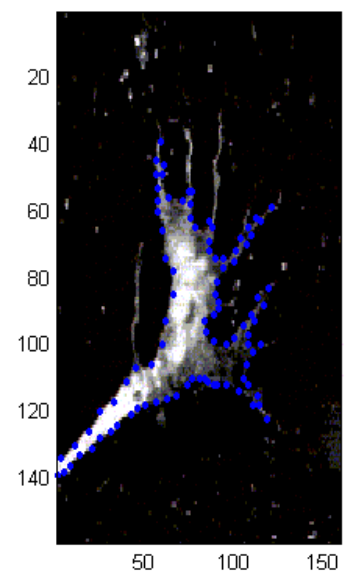

(a)

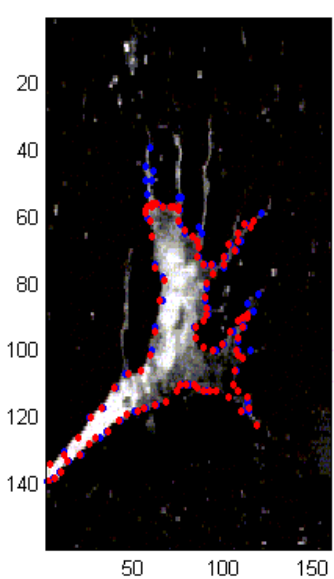

(b)

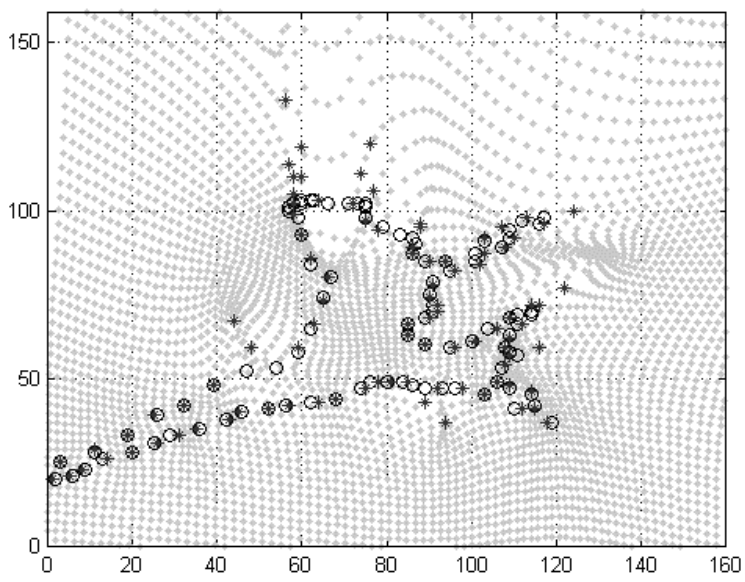

(c)

Figura 39 - Utilização de pares de thin plate pair na movimentação de um dendrito do neurônio.

(a) imagem do neurônio sobrepostos com pontos de controle iniciais (azul), (b) imagem sobreposta com pontos modificados (vermelho) e (c) interpolação gerada a partir do pontos considerados.

As Figuras 38 e 39 conseguem determinar qual o grau de deformação para cada ponto do neurônio de um instante ao outro, e determinar quanto de energia foi necessário para cada processo. Podemos observar que as regiões onde a ramificação era modificada a superfície sofria distorções, cuja amplitude depende diretamente do quanto a ramificação foi modificada.

A hipótese adotada para as thin plate spline é que a evolução da curva ao longo do tempo se dá através das restrições impostas pelo modelo. A thin plate considera que o próximo instante da evolução é especificado como uma função analítica $f$ do instante anterior, $\vec{c}(s, t+\Delta t)=f(\vec{c}(s, t))$, o que pode ser especificado para cada uma das componentes, $f_{x}$ e $f_{y}$. $\mathrm{O}$ método consiste em representar as funções em termos de 
polinômios definidos nas coordenadas do instante anterior, seguido por uma interpolação utilizando mínimos quadrados entre os valores estimados e os reais. Uma alternativa é utilizar uma solução variacional para minimizar essa diferença e impor restrições aos contornos a serem estimados, tais como suavizadade da função [Costa(2000)]. Para as seqüências de imagens apresentadas definimos os pontos de controle em um instante inicial e no posterior, obtendo assim a interpolação do contorno no segundo instante através da thin plate. A Figura 40 apresenta dois instantes diferentes de um mesmo contorno em (a), sendo o preto o instante inicial e o vermelho o final, com seus respectivos pontos de controle. Em (b) temos a reconstrução utilizando thin plate e os pontos de controle em vermelho e a curva original (segundo instante) em preto. Podemos observar que a interpolação da curva usando thin plate splines apresenta bons resultados, mesmo em regiões que não são tão próximas aos pontos de controle.

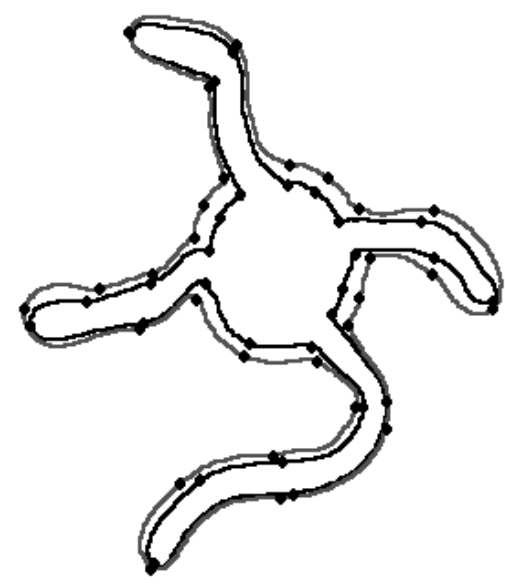

(a)

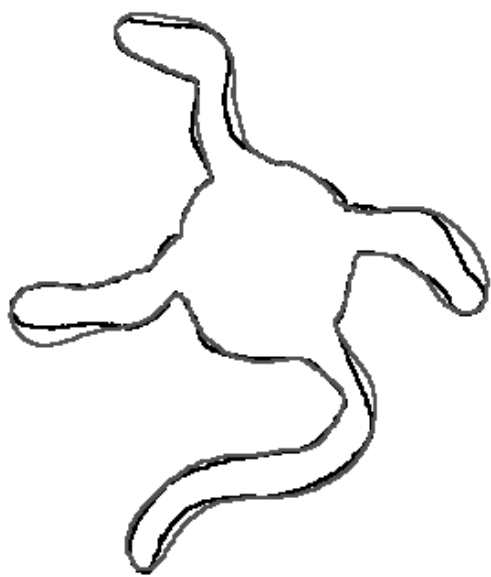

(b)

Figura 40 - Interpolação usando Thin-plate para checar o mecanismo de evolução.

\subsection{Dinâmica das Actinas}

De acordo com as características biológicas apresentadas na Seção 2.2.2, podemos imaginar um modelo de crescimento baseado na polimerização da actina, dada a velocidade de polimerização de um filamento. Além disso, podemos admitir que esse filamento empurra a membrana, gerando sua deformação. Em uma situação ideal o 
filamento iria produzir uma força sobre a membrana que poderia ser calculada de acordo com sua velocidade e com a capacidade de deformação da membrana.

Desse modo, uma alternativa simples para o tratamento da deformação elástica da membrana é obtido através da sua representação por meio de sistemas de massasmolas interligados, formando um círculo fechado (membrana), que seria a posição inicial do sistema. De acordo com o crescimento dos filamentos teríamos uma força atuando em uma posição específica da membrana.

No caso de um sistema massa-mola a força que atua entre os componentes é uma força restauradora, que tende a trazer o sistema para a posição de equilíbrio inicial, uma interessante analogia a elasticidade da membrana biológica. Essa força é sempre contrária a direção de deslocamento e sua intensidade depende da constante de mola do sistema e do deslocamento efetuado. No caso da membrana considere um sistema massa-mola acoplado com M molas e $\mathrm{N}$ massas. Nesse sistema, a mola $k$ sofre ação das molas $k-1$ e $k+1$, e no caso em repouso temos que a somatória das forças sobre um ponto é zero.

Considere que um filamento de actina cresce, de acordo com regras préestabelecidas, e gera uma força sobre a membrana causando a sua deformação. Essa nova posição da membrana encontra-se em equilíbrio de tal modo que a somatória das forças seja igual a zero, onde temos as forças na posição inicial, as forças na nova posição e a força externa, conforme descrito na Eq. (41).

$$
\sum F_{\text {inicial }}+\sum F_{\text {final }}+\sum F_{\text {externa }}=0
$$

No caso de molas acopladas, a força sobre uma massa $k$ é dada pela Equação (42), onde $\mathrm{K}$ é a constante de mola, $x_{k}$ é a posição inicial da massa $k$ e $x^{\prime}{ }_{k}$ a sua posição após a aplicação da força e a deformação da mola. A força resultante em um ponto é dada pela força entre os vizinhos mais próximos apenas.

$$
F_{k}=-K\left[\left(x_{k+1}-2 x_{k}+x_{k-1}\right)-\left(x_{k+1}^{\prime}-2 x_{k}^{\prime}+x_{k-1}^{\prime}\right)\right]
$$

Substituindo a Eq. (42) em (41) temos como resultado a Equação (43), que é a equação de forças do sistema em estudo. 


$$
\sum_{k=1}^{N}\left\{-K\left[\left(x_{k+1}^{\prime}-2 x_{k}^{\prime}+x_{k-1}^{\prime}\right)-\left(x_{k+1}-2 x_{k}+x_{k-1}\right)\right]+F_{\text {externa }}\right\}=0
$$

Considerando que a diferença entre a posição inicial $\left(x_{k}\right)$ e a nova posição $\left(x^{\prime}{ }_{k}\right)$ no ponto $k$ seja dado pela expressão da Eq. (44). Podemos simplificar a Eq.(43) e reescrevê-la como a Eq.(45).

$$
\begin{gathered}
\Delta_{k}=x_{k}^{\prime}-x_{k} \\
\sum_{k=1}^{N}\left\{-K\left[\Delta_{k+1}-2 \Delta_{k}+\Delta_{k-1}\right]+F_{\text {externa }}\right\}=0
\end{gathered}
$$

Assim, temos que a somatória de todas as forças nos pontos $k$ adicionados a força externa é igual a zero. Nessa abordagem, a força externa será a força que o microfilamento faz sobre a membrana durante o crescimento. Em um caso limite, a força será apenas em um ponto da membrana.

Desse modo, considere a posição inicial dos pontos da membrana e também a posição final em apenas um dos pontos, ponto de atuação da força. Os vizinhos mais próximos irão se mover segundo uma força restauradora do seu ponto vizinho em movimento. Conhecendo então as posições iniciais e a força externa, o objetivo é descobrir quais serão as posições finais de equilíbrio nesse sistema sob a ação da força externa e das forças impostas pelas molas vizinhas. Como o sistema de massamola constitui um sistema fechado, podemos utilizar a série de Fourier para expandir as diferenças entre as posições iniciais e finais, considerando:

$$
\hat{\Delta}_{k}=\sum_{k=1}^{N} \Delta_{k} e^{\frac{2 \pi i k M}{N}} \quad \Rightarrow \quad \Delta_{k}=\sum_{k=1}^{N} \hat{\Delta}_{k} e^{\frac{-2 \pi i k M}{N}}
$$

Logo, podemos expandir os coeficientes $\Delta_{k}$ e $\hat{\Delta}_{k}$ em função de seus coeficientes de Fourier. Procedimento análogo pode ser feito com relação às forças. 


$$
\hat{F}_{k}=\sum_{k=1}^{N} F_{k} e^{\frac{2 \pi i k M}{N}} \quad \Rightarrow \quad F_{k}=\sum_{k=1}^{N} \hat{F}_{k} e^{\frac{-2 \pi i k M}{N}}
$$

Substituindo os itens acima na Equação (45), resultamos na Eq. (46) e (47):

$$
\begin{gathered}
-K\left[\sum_{k=1}^{M} \hat{\Delta}_{k} e^{\frac{-2 \pi i(k+1) M}{N}}-2 \sum_{k=1}^{M} \hat{\Delta}_{k} e^{\frac{-2 \pi i k M}{N}}+\sum_{k=1}^{M} \hat{\Delta}_{k} e^{\frac{-2 \pi i(k-1) M}{N}}\right]+\sum_{k=1}^{M} \hat{F}_{k} e^{\frac{-2 \pi i k M}{N}}=0 \\
-K\left[\sum_{k=1}^{M} \hat{\Delta}_{k} e^{\frac{-2 \pi i k M}{N}} \cdot e^{\frac{-2 \pi i M}{N}}-2 \sum_{k=1}^{M} \hat{\Delta}_{k} e^{\frac{-2 \pi i k M}{N}}+\sum_{k=1}^{M} \hat{\Delta}_{k} e^{\frac{-2 \pi i k M}{N}} \cdot e^{\frac{2 \pi i M}{N}}\right]+\sum_{k=1}^{M} \hat{F}_{k} e^{\frac{-2 \pi i k M}{N}}=0
\end{gathered}
$$

Eliminando-se o termo $e^{\frac{-2 \pi i k M}{N}}$ da Eq. (47) resultamos na Eq. (48).

$$
\begin{gathered}
-K\left[\sum_{k=1}^{M} \hat{\Delta}_{k} e^{\frac{-2 \pi i M}{N}}-2 \sum_{k=1}^{M} \hat{\Delta}_{k}+\sum_{k=1}^{M} \hat{\Delta}_{k} e^{\frac{2 \pi i M}{N}}\right]+\sum_{k=1}^{M} \hat{F}_{k}=0 \\
-\sum_{k=1}^{M} K \hat{\Delta}_{k}\left[e^{\frac{-2 \pi i M}{N}}-2+e^{\frac{2 \pi i M}{N}}\right]+\hat{F}_{k}=0
\end{gathered}
$$

Utilizando $e^{-i \alpha}=\cos (\alpha)-i \sin (\alpha)$ na Eq. (49), obtemos o resultado apresentado na Eq. (50).

$$
-\sum_{k=1}^{M} K \hat{\Delta}_{k}\left[\cos \left(\frac{2 \pi i M}{N}\right)-i \sin \left(\frac{2 \pi i M}{N}\right)-2+\cos \left(\frac{2 \pi i M}{N}\right)+i \sin \left(\frac{2 \pi i M}{N}\right)\right]+\hat{F}_{k}=0
$$

que simplificadamente podem ser representadas pelas Eq. (51) e (52): 


$$
\begin{aligned}
& -K \hat{\Delta}_{k}\left[2 \cos \left(\frac{2 \pi i M}{N}\right)-2\right]+\hat{F}_{k}=0 \\
& -2 K \hat{\Delta}_{k}\left[\cos \left(\frac{2 \pi i M}{N}\right)-1\right]+\hat{F}_{k}=0
\end{aligned}
$$

A Eq. (53) fornece o valor da transformada de Fourier da distância entre as posições finais e iniciais, em função da transformada de Fourier das forças que atuam no determinado ponto. Como os valores da força são conhecidos, dividimos a transformada de Fourier das forças pelos coeficientes apresentados. Em seguida, extraímos a transformada de Fourier inversa para obtermos $\Delta_{k}$.

$$
\hat{\Delta}_{k}=\frac{\hat{F}_{k}}{2 K\left(\cos \left(\frac{2 \pi i M}{N}\right)-1\right)}
$$

Conhecendo os valores de $\Delta_{k}$, utilizamos a Eq (44) para obtermos o valor da posição final $\left(x_{k}^{\prime}\right)$ da membrana após a aplicação das forças. O modelo consiste basicamente na implementação dos passos descritos na polimerização das actinas e na sua atuação na modificação da forma da membrana, descrita pela lei restauradora.

Com o objetivo de inserir no modelo as características biológicas dos neurônios, implementamos, de forma simplificada, os 10 estágios biológicos de crescimento descritos na Seção 2.2.2, além de geramos alguns filamentos em direções prédeterminadas (horizontais e verticais) onde uma região específica da célula foi ativada. Suponha a representação apresentada na Figura 41(a), onde a membrana celular é o círculo em azul, e as proteínas são os vetores no seu interior com suas respectivas direções de crescimento. As proteínas que estão circuladas em vermelho representam as nucleações e foram ativadas por um determinado impulso em uma região da membrana, ou seja, tiveram seus Wasp/Scar (que foram colocados em posições aleatórias da membrana) ativados, e conseqüentemente ativaram uma actina livre. A partir desse processo, o filamento de actina se alonga (em vermelho), de acordo com a velocidade de crescimento descrita anteriormente e com a 
concentração de actinas livres na célula. Nesse caso, estamos considerando uma interação simples do filamento com a membrana, através de uma força de distribuição gaussiana do filamento sobre a membrana, forte na região central e decaíndo em suas extremidades, conforme apresentado na Figura 41(b).

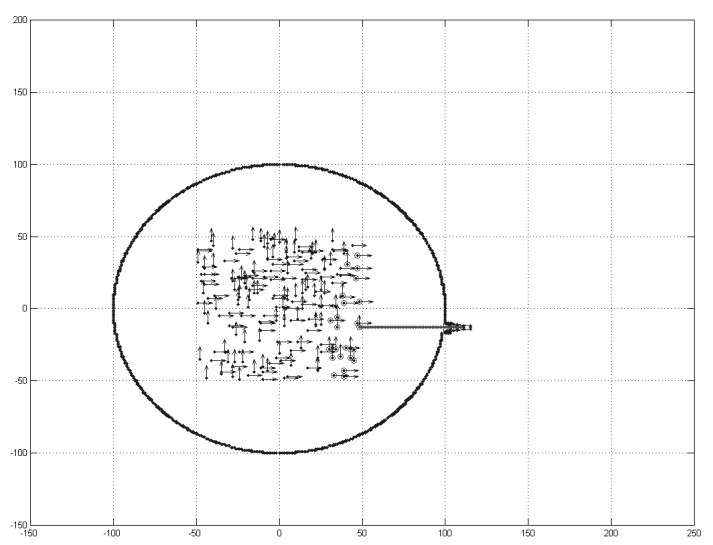

(a)

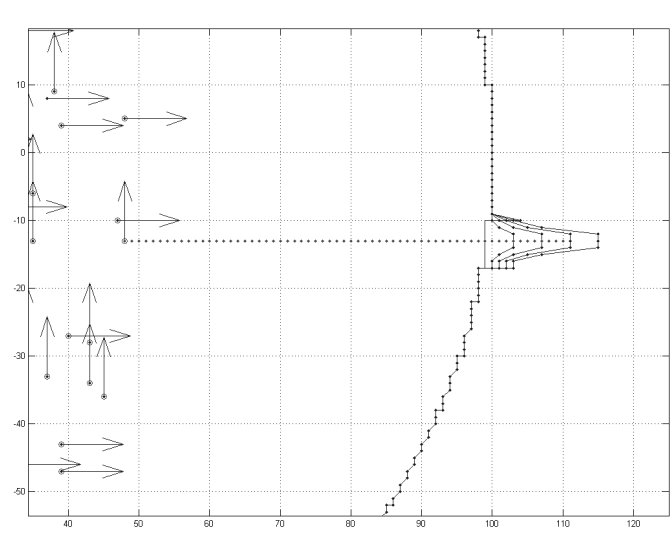

(b)

Figura 41 - Exemplo de uma simulação considerando a ação da força como uma gaussiana (a) e um zoom da parte onde a actina empurra a membrana (b).

Podemos verificar visualmente que esse processo não consegue descrever completamente o que ocorre biologicamente na membrana, pois o modelo leva apenas em consideração o aspecto localizado da força. Desse modo, para ampliarmos a abrangência desse modelo, implementamos uma simulação inicial utilizando a idéia de força restauradora na membrana, conforme descrito anteriormente. Inicialmente, na Figura 42(a), temos um círculo com posições conhecidas (em azul). Movimentamos um dos pontos do círculo para uma nova posição (vermelho) e calculamos quais seriam as novas posições de todo o contorno, Figura 42(b) em vermelho, seguindo o conceito de força restauradora. 


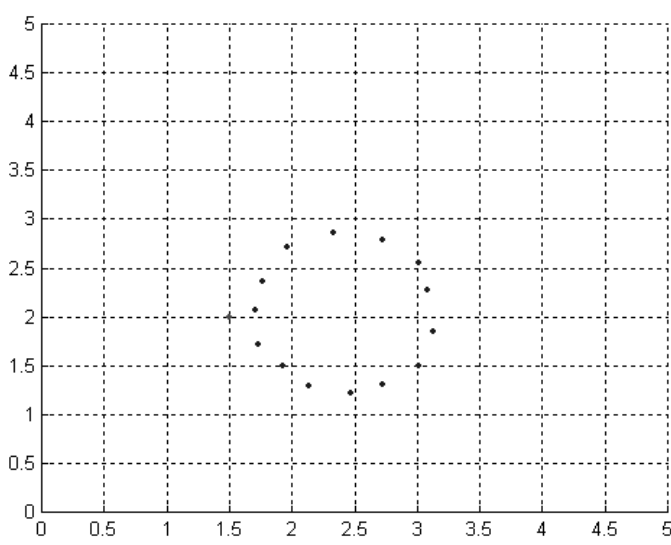

(a)

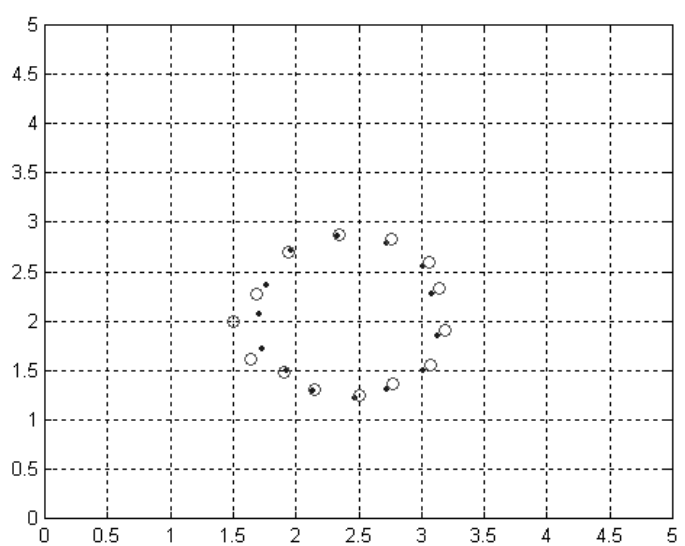

(b)

Figura 42 - (a) Imagem inicial em azul com ponto modificado em vermelho, (b) resultado (em vermelho) da aplicação de forças de mola entre os pontos.

O mais interessante dessa abordagem é que os pontos possuem interação entre si, passando a idéia do que acontece biologicamente em uma célula entre as proteínas da membrana. Além disso, a abordagem e o cálculo das posições mostra-se bastante rápido e eficiente, uma vez que utilizamos a transformada de Fourier. Entretanto, notamos na simulação que temos uma movimentação de todos os pontos do contorno, ou seja, a interação age de forma muito global. Uma idéia seria atribuir "pesos" aos pontos, de modo que, quanto maior o peso, mais longe da força o ponto estaria, e menor seria a sua movimentação. Assim, devemos atribuir uma certa restrição a movimentação dos pontos, essa restrição poderia ser dada pelas posições anteriores. Essas alternativas na modelagem podem ser obtidas de um modo mais formal e matemático se utilizarmos uma abordagem baseada em Snakes para a representação da membrana, uma vez que essas restrições já estão inerentemente incorporadas na sua formulação. A seguir, descreveremos um modelo que utiliza Snakes e restrições que governam o seu crescimento.

\subsection{Contornos Ativos acoplado a Potencial Externo}

O nosso interesse na formulação dos contornos ativos deve-se ao fato dessa abordagem possuir um grande potencial para utilização em evolução de curvas, pois consegue, ao mesmo tempo, englobar restrições internas e externas do modelo 
considerado. Desse modo, a proposta final e mais completa de modelo para evolução engloba um contorno descrito sob a formulação de contornos ativos, considerando algumas restrições externas que possuem uma grande analogia aos fatores de crescimento biológicos.

Na Seção 4.2 apresentamos a metodologia de contornos ativos que utiliza como força externa atratora o gradiente da imagem inicial. Essa abordagem é muito utilizada para algoritmos de detecção de bordas. Entretanto, ela apresenta algumas desvantagens quando aplicada em imagens ruidosas (imagens com máximos locais), ou quando a Snake não se encontra perto o suficiente do gradiente da imagem para ser atraído por ele. Em 1991, Cohen(1991) propôs uma alternativa ao modelo de Snakes tradicional adicionando um segundo termo à força externa, uma força normal a superfície da curva, essa nova formulação é denominada Snake Balloon.

A Snake Balloon apresenta uma força análoga a uma pressão uniforme e constante ao longo de todo o contorno, na direção normal a curva. Essa força deixa o contorno com um comportamento dinâmico, e a curva passa a ser considerada como um balão que pode inflar, criando uma pressão de dentro para fora da curva. Nesse caso, o terceiro termo da Eq. (26), que antes se referia apenas a imagem, passa a ser dado pela Eq. (54).

$$
E_{\text {imagem }}(v(s))=k_{1} \vec{n}(v(s))-k_{2} \frac{E_{\text {gradiente }}(v(s))}{\left\|E_{\text {gradiente }}(v(s))\right\|}
$$

$\mathrm{Na}$ Eq. (54), $\vec{n}$ é um vetor unitário e normal a curva no ponto $v(s)$, e $k_{l}$ é a amplitude dessa força. Ao mesmo tempo em que a curva se expande sob a ação da pressão, o gradiente da imagem atua como um atrator para o contorno, como no caso anterior, e os valores de $k_{1}$ e $k_{2}$ determinam o peso entre eles. A implementação computacional da Snake Balloon é feita através da discretização das derivadas pelo métodos dos elementos finitos, onde a solução é colocada na forma matricial. $\mathrm{O}$ desenvolvimento completo dessa técnica pode ser encontrado em [Cohen(1993), Chenyang(1998)]. Essa modificação na formulação da Snake a torna apropriada ao nosso problema de modelagem de células, pois temos uma força que permite ao contorno inflar, possibilitando a criação de estruturas do tipo de ramificações. Nessa 
abordagem, as ramificações geradas não foram diferenciadas quanto a geração de axônio ou dendritos.

Utilizando a abordagem de Snake Balloon geramos um modelo de evolução de curvas que nos possibilita gerar estruturas ramificadas semelhantes às células neurais. A proposta é utilizar uma abordagem baseada em contornos para o tratamento da evolução de uma membrana neural. Ese tipo de abordagem é inédita e possui um grande realismo quanto à forma neural. Tal motivação é baseada na elaboração de um modelo mais completo e realista de crescimento de uma célula neural, do que os propostos na literatura até o momento. Neste contexto, foram adicionadas restrições à formulação matemática da Snake Balloon que fossem baseadas em características biológicas de crescimento de células reais. A modelagem é baseada em duas hipóteses para o crescimento da célula, hipóteses que atuam na força pressão da Snake, são elas: ( $i$ ) a do crescimento ser proporcional a curvatura do contorno, na direção de sua normal e (ii) que também seja proporcional ao gradiente de uma distribuição de cargas baseado em processos de difusão limitados (diffusionlimited process) [Witten(1981) e Neimeyer(1984)].

Nossa formulação permite que essas duas forças atuem como pressão sobre o contorno, onde o movimento do contorno é dado pela resultante da soma vetorial entre os vetores da curvatura (na direção normal) e o vetor do gradiente do potencial elétrico em cada ponto do contorno. Conforme ilustrado em Figura 43, os vetores em azul representam a curvatura na direção normal, enquanto os vetores em vermelho, o gradiente do potencial elétrico e os pretos a resultante entre eles. As duas hipóteses apresentadas possuem realismo biológico, uma vez que o crescimento de células se dá, na sua grande maioria das vezes, (i) em regiões de pontas de ramificações [Lasek(1986), Okabe(1991), Futerman(1996)], alta curvatura, e (ii) devido a ação de campos externos, tais como elétricos e químicos, pois geram uma grande influência sobre o seu crescimento e sobre a sua forma neural [Lasek(1986), Hely(1998), Kalil(2000) e Matus(2000) e Van Ooyen(2001)]. Tais hipóteses foram comentadas na Seção 2.2.2. Podemos imaginar que as regiões de alta curvatura são regiões de concentração dos filamentos de actinas que crescem de forma ordenada e nas extremidades dos filamentos. 


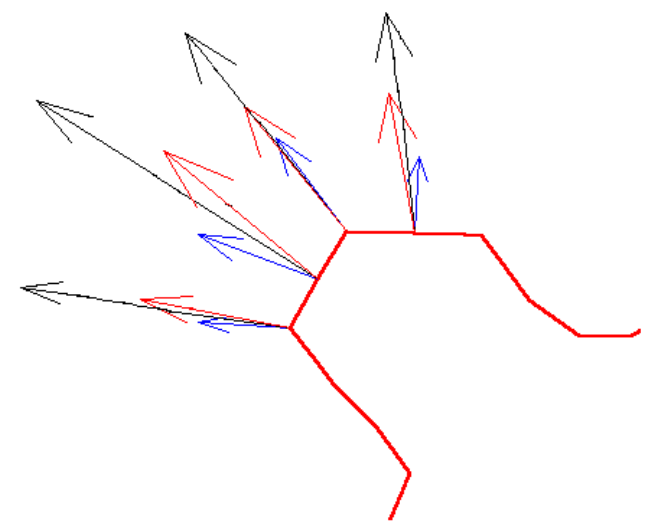

Figura 43 - Ilustração da soma vetorial da curvatura (em vermelho), gradiente do campo elétrico (em azul) e a resultante (em preto), onde a resultante determina a movimentação da membrana.

A motivação para essa abordagem do potencial elétrico surgiu através dos modelos de crescimento conhecidos como DLA, agregação por difusão limitada (diffusion-limited agregation). O modelo DLA foi inicialmente proposto por Witten e Sander em 1981 [Witten(1981)] para o estudo de agregação de partículas de metal cujas correlações foram previamente medidas, e caem com a distância seguindo uma lei fracionária de potência. Ele incorpora duas características que podem ser atribuídas a modelos de crescimento dendrítico, são elas: $(i)$ os fatores controlando o crescimento são baseados em equações de difusão, e (ii) o processo de crescimento obedece regras estocásticas de crescimento. A principal característica do modelo é que o crescimento segue regras que representam a solução das equações para processos de difusão limitados, incluindo a presença de ruídos estocásticos. O modelo DLA é bem conceituado nos meios acadêmicos [Witten(1981), Neimeyer(1984), Caserta(1990)] e acredita-se que ele consiga descrever de forma bastante razoável o fenômeno de crescimento por gradientes químicos, elétricos e de diferença de viscosidade. Uma vez que células neurais em crescimento respondem a esses gradientes, acredita-se que o modelo DLA seja também capaz de representar uma aproximação ao crescimento neural.

De acordo com as idéias obtidas do modelo DLA, o potencial elétrico utilizado para a simulação do campo externo é obtido através da resolução da equação de Laplace, em cada instante de tempo, Eq. (55). No caso bidimensional, considerando uma grade ortogonal, a formulação discreta é dada pela Eq. (56). 


$$
\begin{gathered}
\nabla^{2} \phi=0 \\
\phi_{i, j}(t)=\frac{1}{4}\left(\phi_{i+1, j}+\phi_{i-1, j}+\phi_{i, j+1}+\phi_{i, j-1}\right)
\end{gathered}
$$

A convergência da Eq. (56) depende fortemente do número de iterações ao qual a equação é submetida. Tipicamente utiliza-se um grande número de iterações, de modo que se garanta a total convergência do resultado. Dado um contorno inicial, ele irá funcionar como a membrana em crescimento de um neurônio, onde a sua energia é calcula em função da formulação de Snake Balloon, e as forças externas que atuam no contorno são proporcionais a sua curvatura e ao potencial elétrico sobre um ponto específico da forma. A curvatura do contorno é calculada de acordo com o método de Fourier proposto por [Cesar(1995) e Estrozi(2003)], e o potencial elétrico é obtido pela solução da equação de Laplace. O potencial elétrico $\phi$ é definido em todos os pontos da grade pela equação discreta de Laplace com condições de contorno $\phi=0$ para cada ponto da membrana, e $\phi=1$ nos locais onde o as cargas estão localizadas. A Figura 44 apresenta um exemplo do laplaciano da distribuição de cargas onde temos o contorno inicial em preto, e o potencial de forma circular ao redor do contorno.

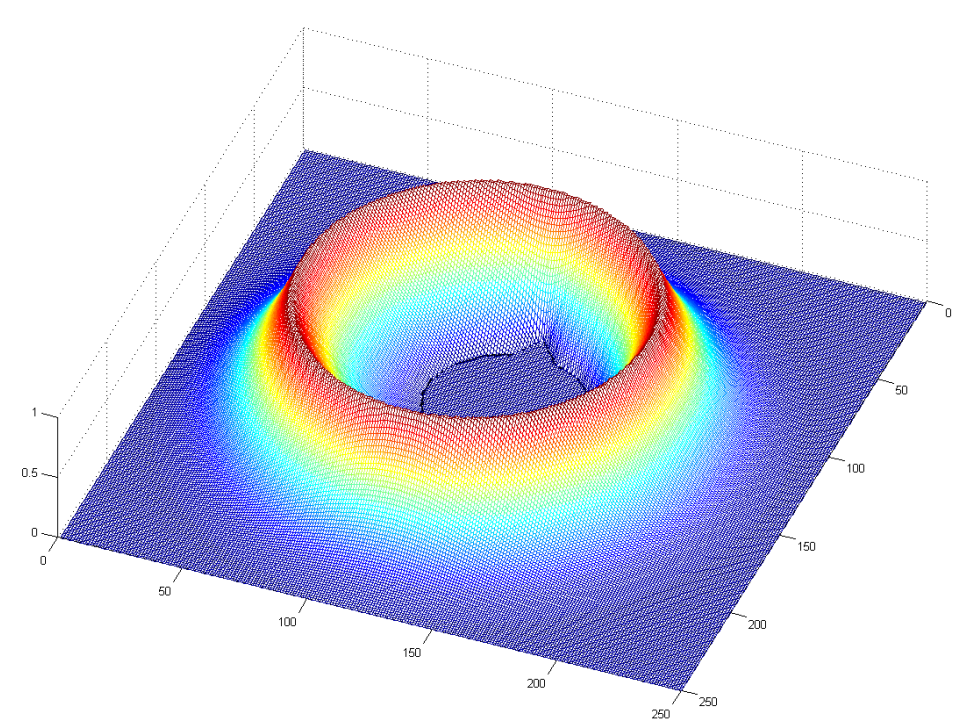

Figura 44 - Exemplo do laplaciano de uma distribuição de cargas circular atuando sobre uma determinada curva (em preto). 


\subsubsection{Resultados}

Nesta Seção apresentamos os resultados obtidos para a simulação do modelo de contornos ativos sob a ação de campos elétricos e a curvatura da membrana. A partir do conhecimento que o campo elétrico gera uma variação na forma neural, o objetivo principal é simular o desenvolvimento do neurônio e realizar uma variação da forma da distribuição de cargas ao redor da membrana, avaliando a sua influência sob a forma das ramificações neurais obtidas. Foram utilizados campos elétricos circulares, pontuais, em forma de barra e também morfologias análogas a outras estruturas neurais.

Na Figura 45 apresentamos os resultados obtidos para uma figura circular com protuberâncias ao longo do contorno para distribuições de carga com formas geométricas. As Figuras 45 (a), (c) e (e) representam o contorno inicial, em azul, e os potenciais elétricos considerados, em vermelho. As formas das distribuições de carga utilizadas foram, respectivamente, um círculo, uma reta, um ponto. Os resultados dos desenvolvimentos obtidos através de evolução de contornos com Snake Balloon, sob a ação dos potenciais e da curvatura, podem ser vistos nas Figuras 45 (b), (d) e (f). As curvas em azul são as evoluções ao longo do tempo, e a curva em preto, a evolução final do contorno. 


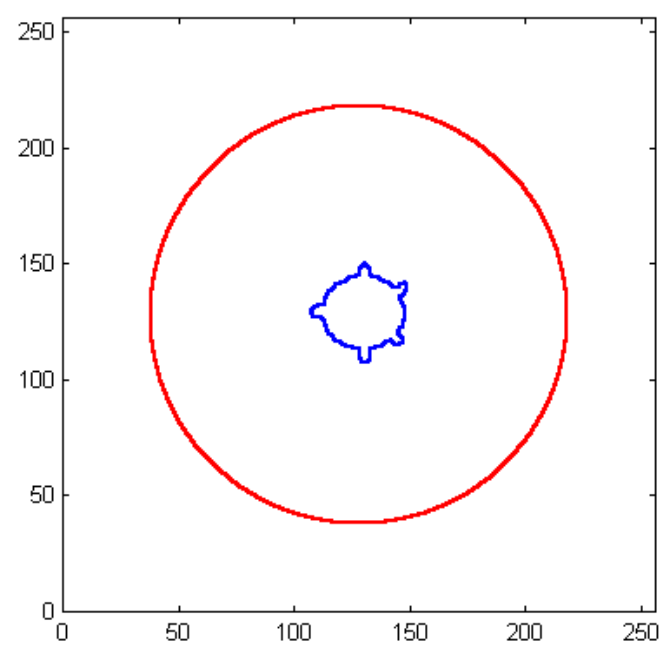

(a)

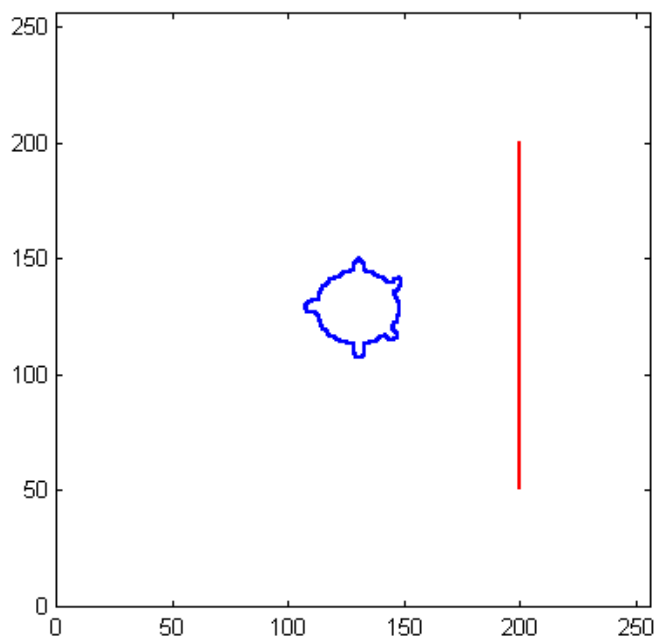

(c)

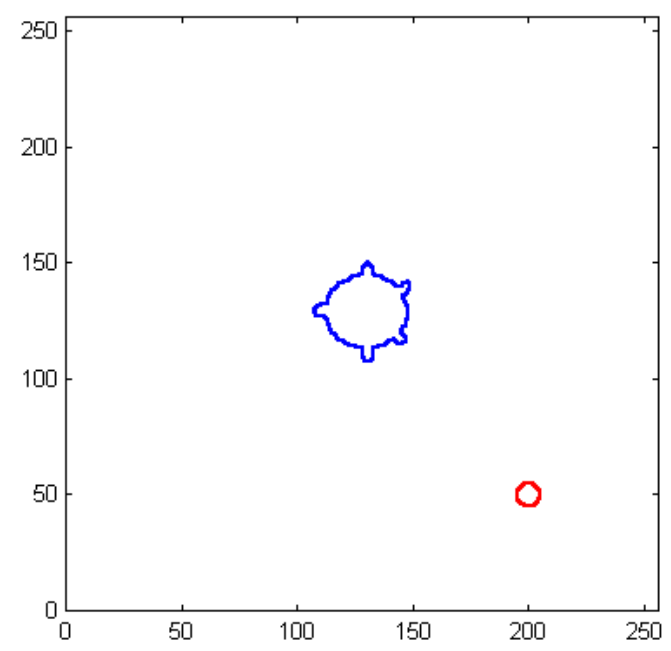

(e)

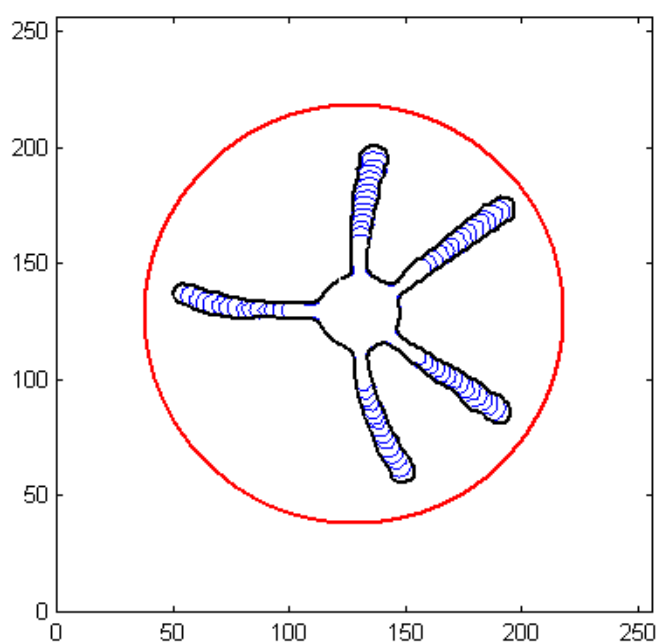

(b)

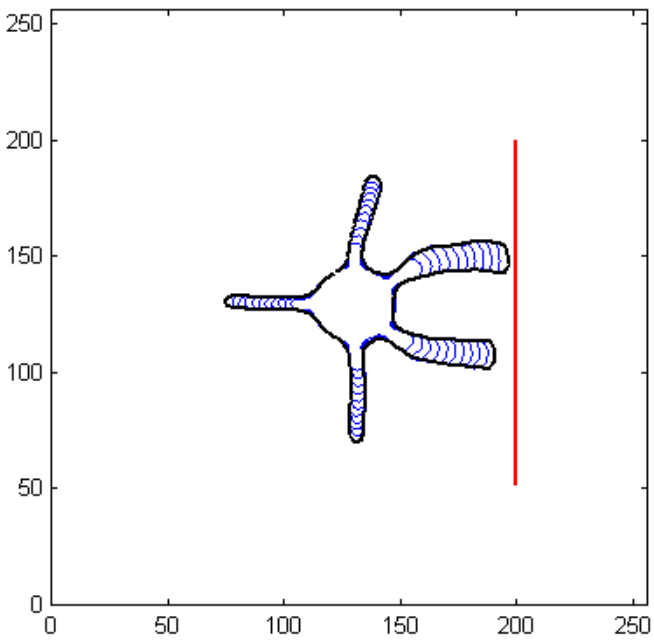

(d)

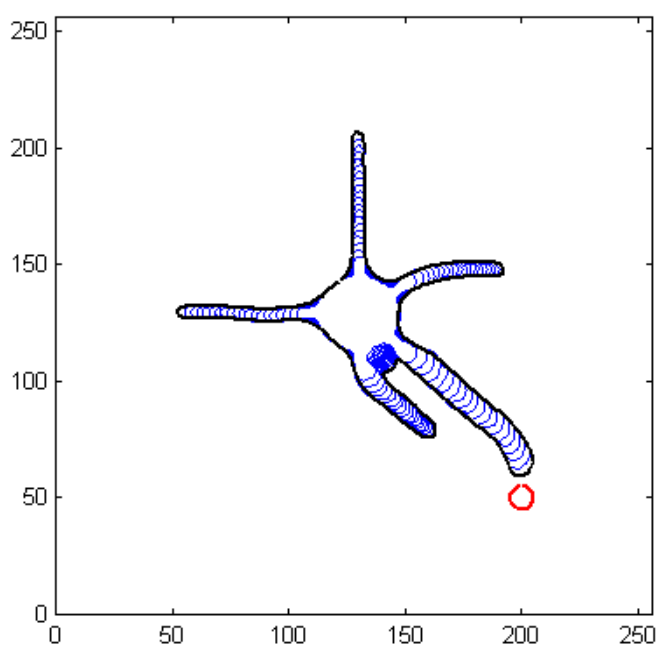

(f)

Figura 45 - Resultados obtidos da simulação do crescimento utilizando potencial externo e curvatura nos itens (b), (d) e (f). Os itens (a), (c) e (e),representam a figura inicial (em azul) e os campos elétricos (em vermelho). 
A Figura 46 apresenta os resultados da evolução do contorno obtidos para uma figura circular com protuberâncias, utilizando distribuições de carga com forma semelhantes a neurônios. Os itens (a), (c) e (e) apresentam o contorno inicial (em azul) e os campos elétricos (em vermelho). Em (b), (d) e (f) temos o resultados das evoluções proporcionais aos campos elétricos e a curvatura. Em azul temos as suas evoluções ao longo do tempo e em preto, o resultado final após um determinado tempo.

Os resultados apresentados pelo modelo de desenvolvimento na Figura 45 e 46 parecem representar muito bem a forma do neurônio. A partir deles, obtivemos a emergência de estruturas ramificadas do tipo das encontradas nos neurônios, com ramos finos e grossos dependendo da menor ou maior ação do potencial elétrico. Podemos também verificar o efeito de criação de ramos mais grossos no caso (b), onde o campo atua de modo uniforme ao longo das ramificações, gerando ramos de espessura semelhantes. Nesse caso, podemos fazer uma analogia entre os resultados obtidos e o fenômeno que precede as sinapses nas células neurais, um alargamento das extremidades das ramificações [Levitan(1997)]. Além disso, conseguimos obter também a característica importante das células neurais, que é o direcionamento das ramificações pela ação dos potenciais elétricos próximos a determinadas ramificações. Também obtivemos a criação de novas ramificações em alguns dos casos de crescimento. Essas estruturas são associadas aos ramos grossos presentes no início do crescimento e a atuação do campo e da curvatura de forma independente, em cada canto do ramo considerado, dividindo a força em um mesmo ramo e gerando a divisão da ramificação. 


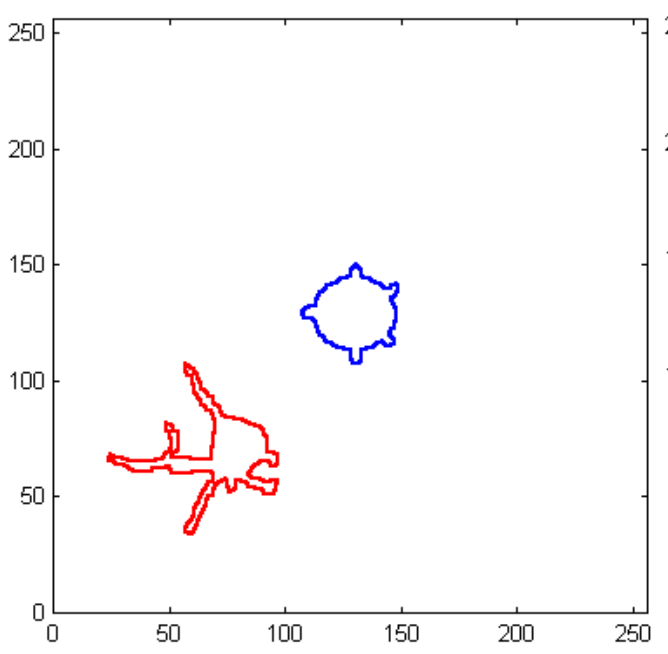

(a)

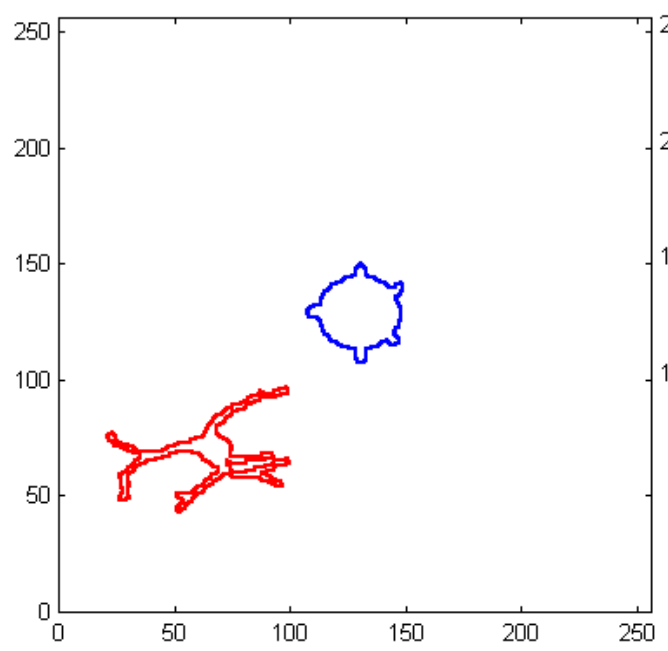

(c)

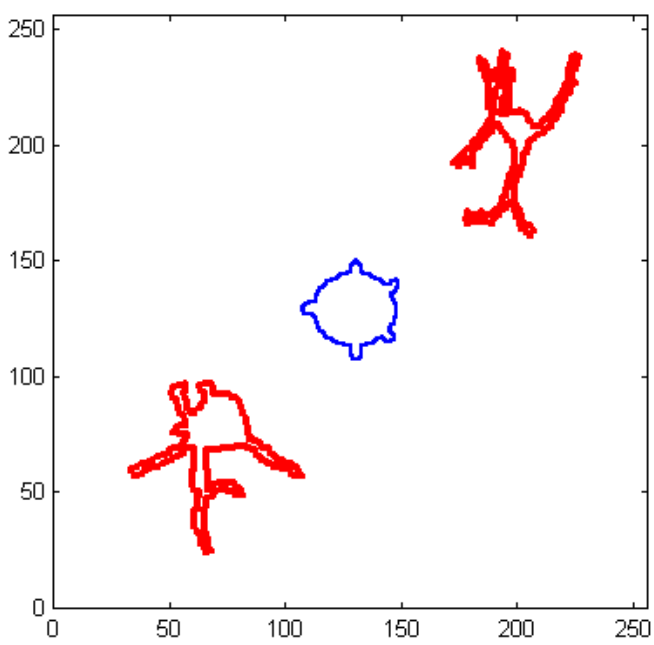

(e)

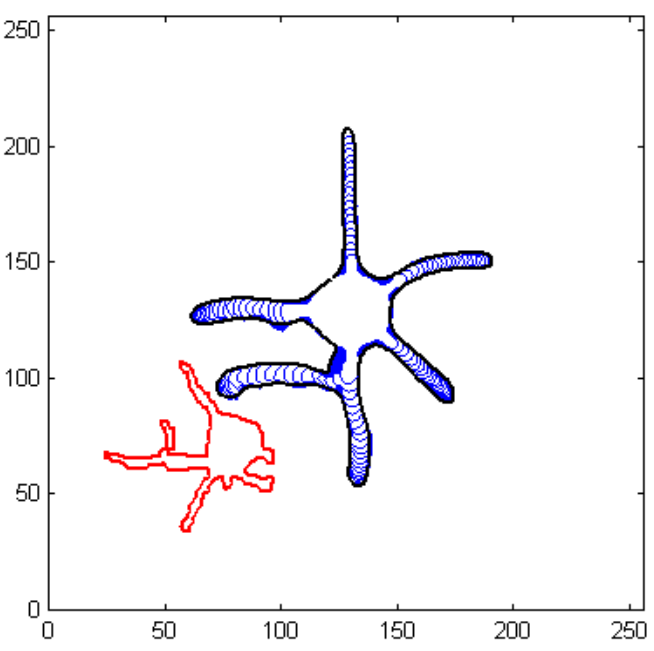

(b)

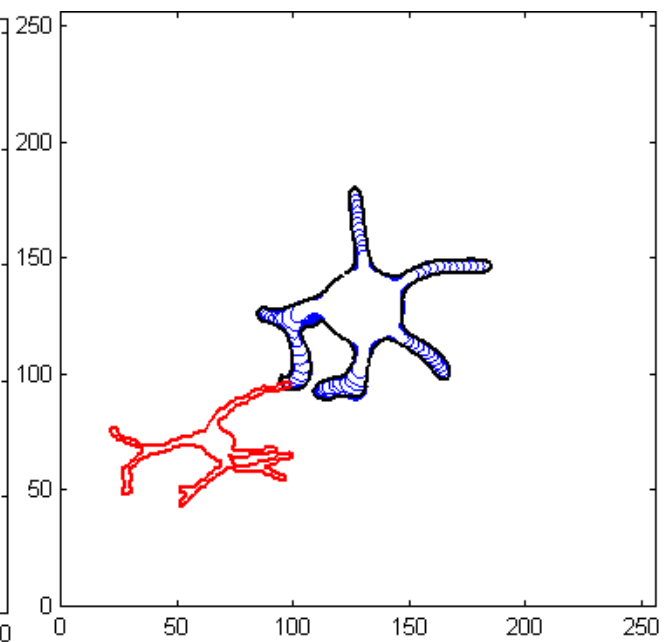

(d)

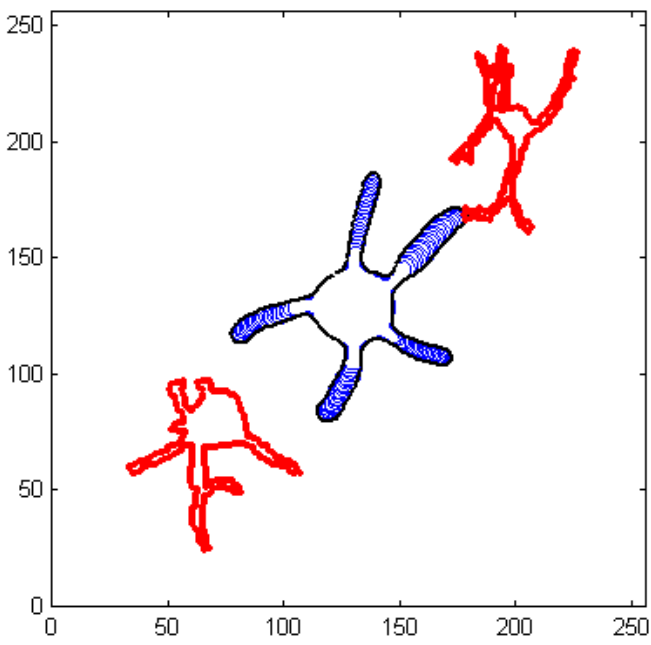

(f)

Figura 46 - Resultados obtidos da simulação do crescimento utilizando potencial externo e curvatura nos itens (b), (d) e (f). Os itens (a), (c) e (e) representam a figura inicial (em azul) e os campos elétricos (em vermelho). 
A Figura 47 apresenta outros resultados de evolução através da ação de campos elétricos e da curvatura. Nesse caso, o contorno inicial é modificado para uma figura com 2 protuberâncias, sendo que uma delas já possui uma pequena subdivisão. Analogamente ao descrito no item anterior, temos os contornos iniciais com seus campos elétricos, (a), (c) e (e), os resultados das evoluções (b), (d) e (f). As curvas em azul representam as evoluções que acontecem ao longo do tempo, enquanto a curva preta representa o resultado final da evolução.

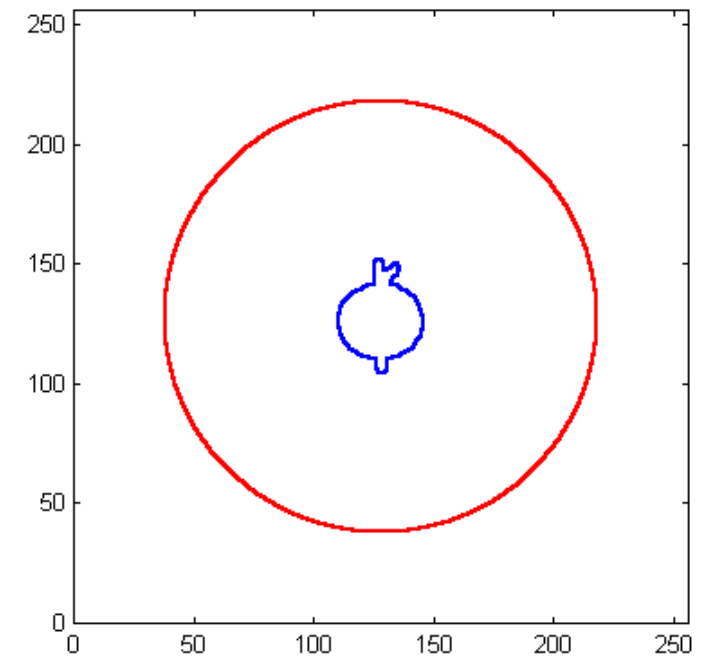

(a)

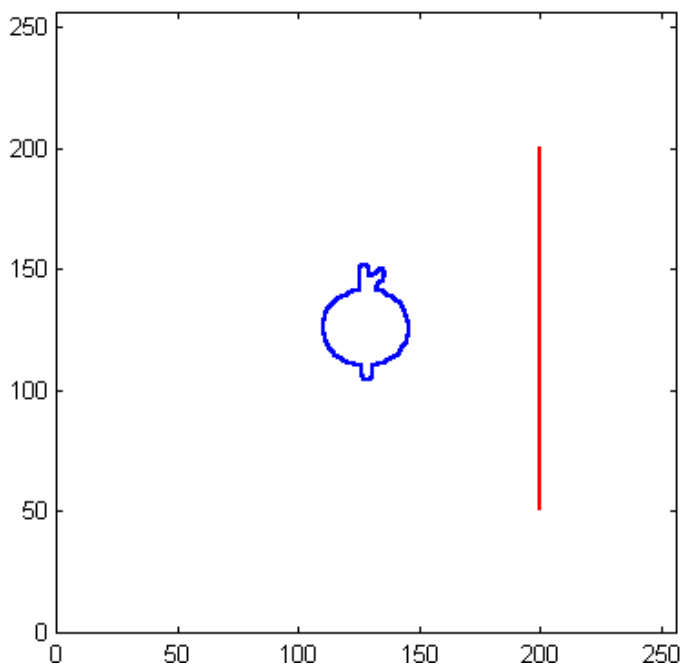

(c)

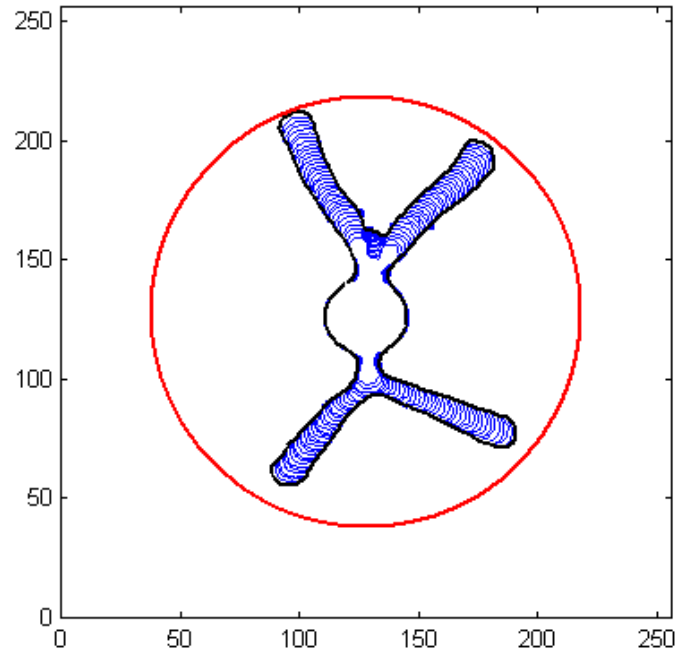

(b)

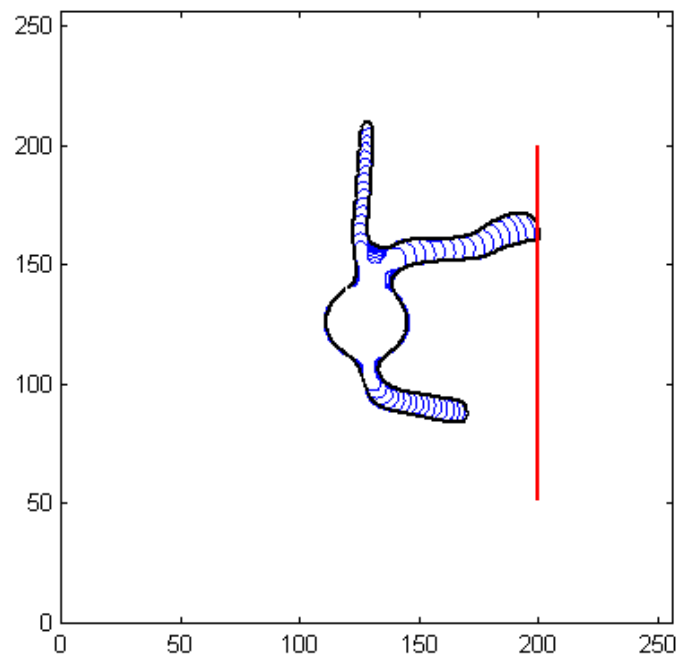

(d) 


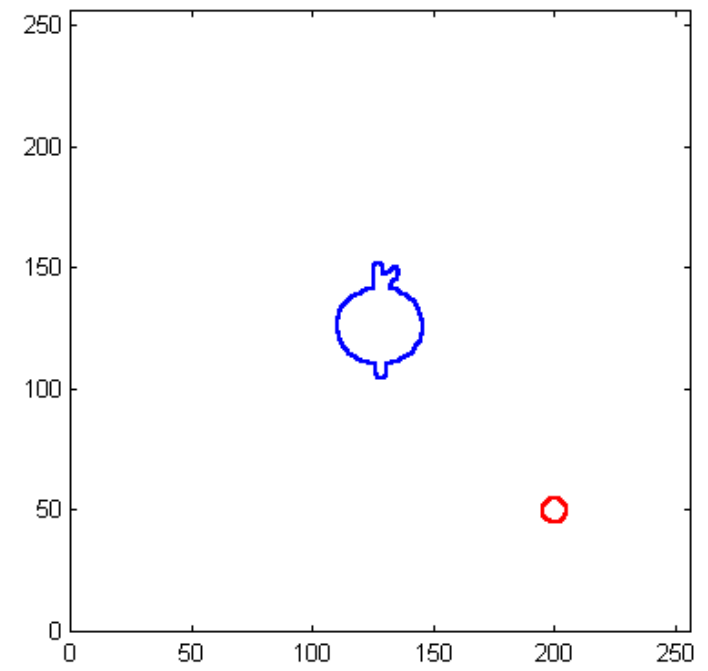

(e)

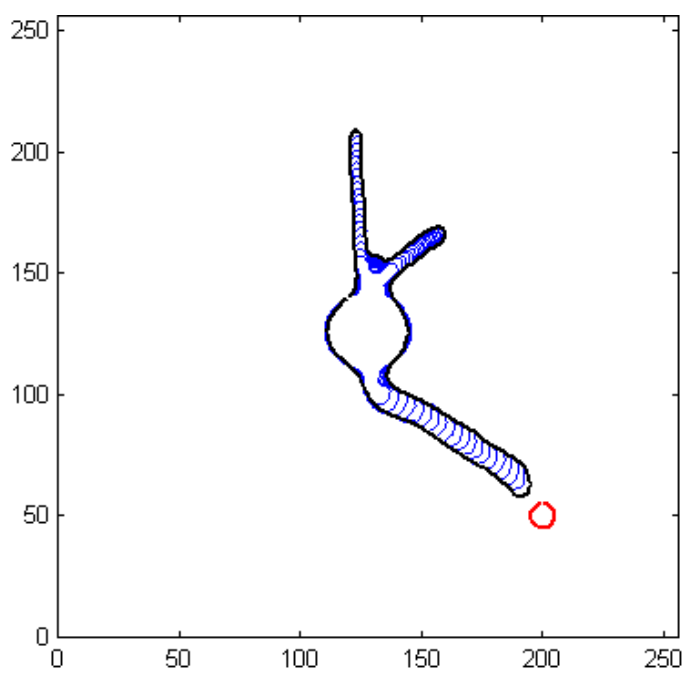

(f)

Figura 47 - Resultados obtidos da simulação do crescimento utilizando potencial externo e curvatura nos itens (b), (d) e (f). Os itens (a), (c) e (e) representam a figura inicial (em azul) e os campos elétricos (em vermelho).

A Figura 48 apresenta as evoluções do contorno obtidos para uma figura circular com duas protuberâncias e utilizando campos elétricos de forma semelhantes a dos neurônios. Os itens (a), (c) e (e) apresentam o contorno inicial (em azul) e os campos elétricos (em vermelho). Em (b), (d) e (f) temos o resultados das evoluções proporcionais aos campos elétricos e a curvatura. Na Figura 48 as curvas em azul representam as diversas evoluções ao longo do tempo, e a curva preta o resultado do crescimento. 


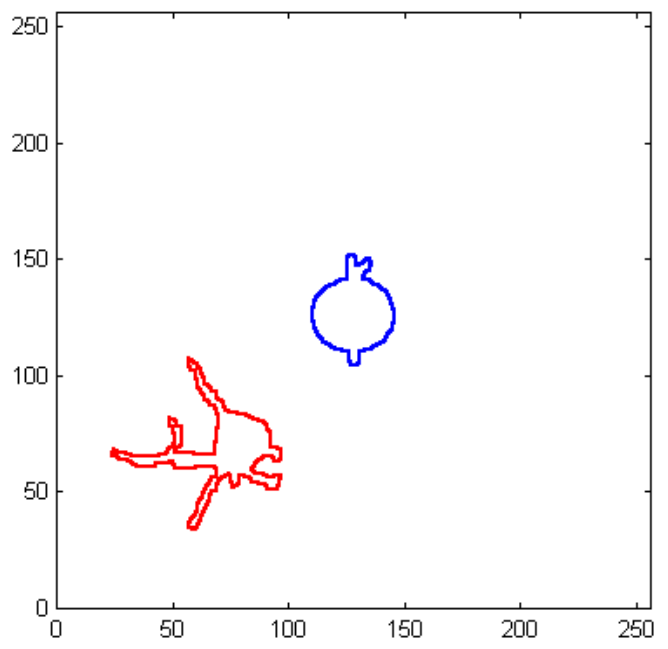

(a)

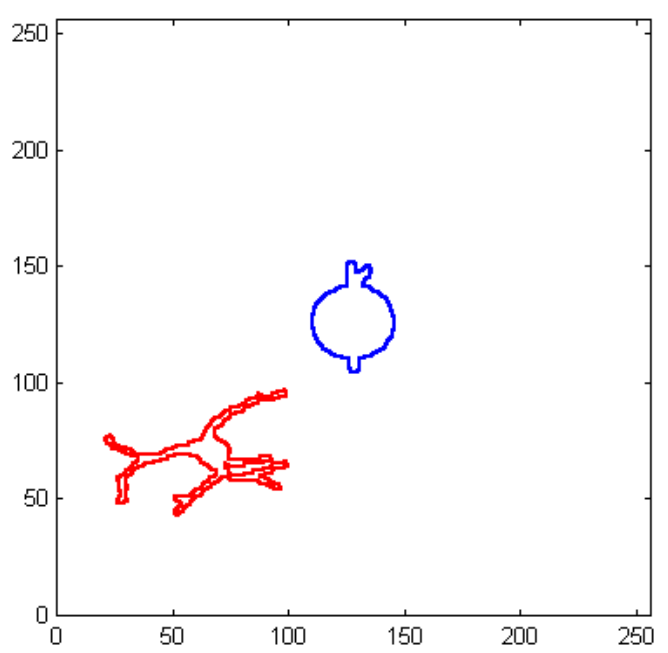

(c)

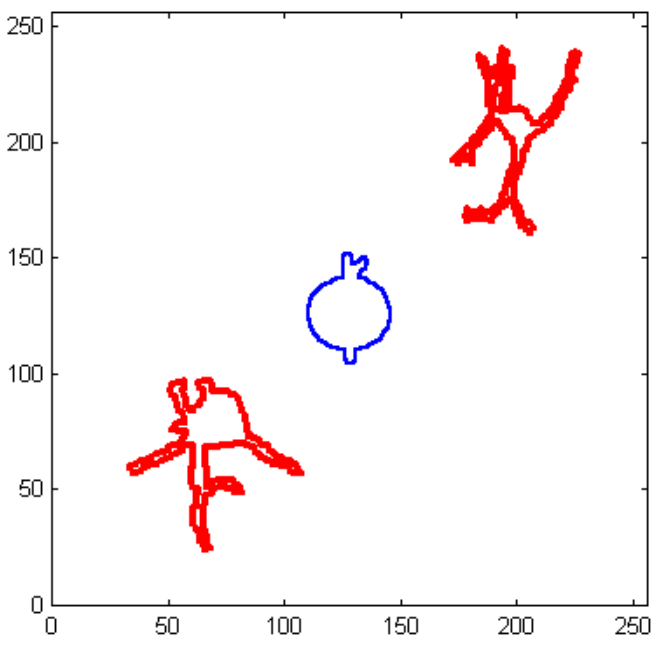

(e)

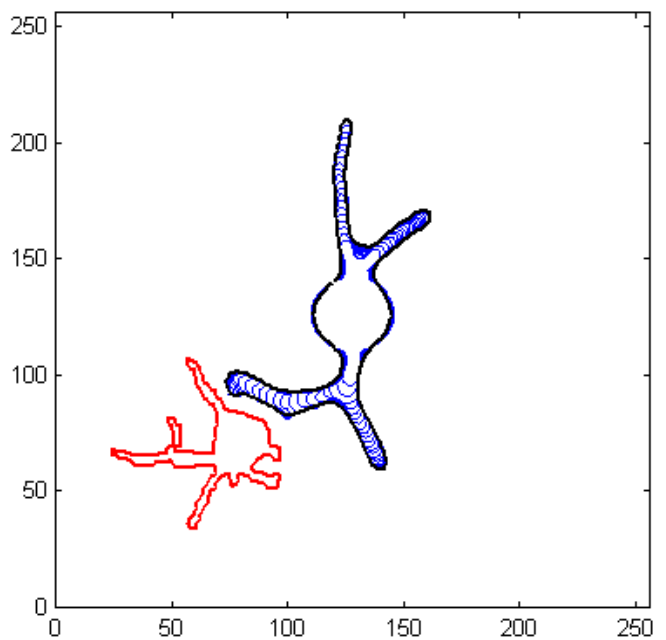

(b)

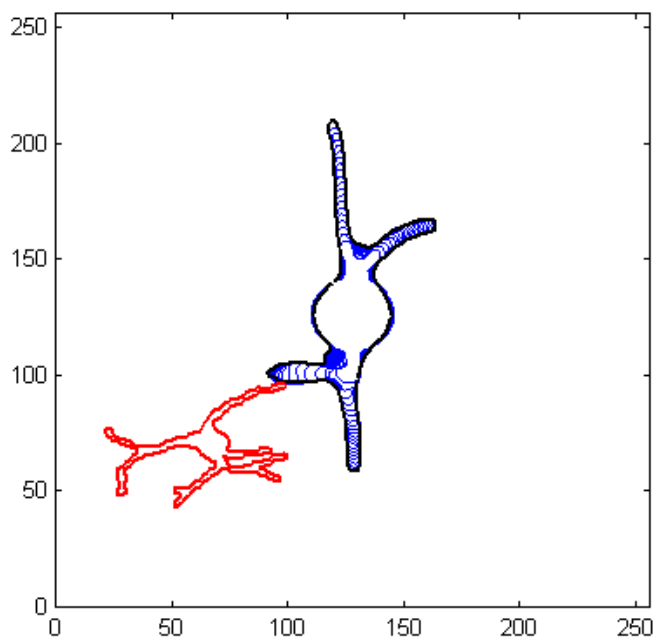

(d)

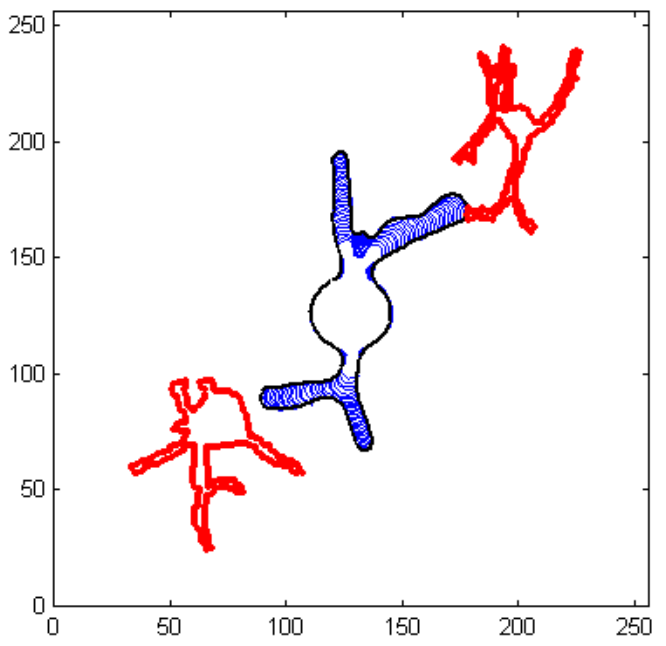

(f)

Figura 48 - Resultados obtidos da simulação do crescimento utilizando potencial externo e curvatura nos itens (b), (d) e (f). Os itens (a), (c) e (e) representam a figura inicial (em azul) e os campos elétricos (em vermelho). 
Nesse segundo conjunto de simulações, com apenas duas protuberâncias iniciais (uma delas já dividida), o pequeno número de ramificações iniciais possibilitou uma melhor análise do efeito dos campos elétricos, da criação de ramificações, e a sua variação de acordo com a ação dos campos elétricos. Nessas simulações também foi observado o fenômeno de alargamento das ramificações devido a ação do campo elétrico, principalmente na Figura 45(b), onde a atuação do campo é constante ao longo de todo o contorno inicial, tal fenômeno também é verificado em resultados biológicos [Kalil(2000)]. O fenômenos de criação de uma nova ramificação pode ser observado e ficou evidente a sua dependência da ação do campo externo. Durante os experimentos de crescimentos de células neurais foi observado que os neurônios com alguma ramificação possuíam uma chance muito grande dessa estrutura ser prolongada na região da extremidade. Além disso, observamos que as células que possuíam vizinhas já ramificadas também aumentavam as suas chances de ramificação.

Além das características científicas desta tese, é importante ressaltar detalhes técnicos sobre as simulações desenvolvidas. Todos os programas, de modelo de crescimento e medidas neuromorfométricas gerados para essa tese, foram desenvolvidos em linguagem Matlab. O computador utilizado foi um micromputador Pentium III- 500Mhz. A grande maioria dos resultados foram obtidos por programas com baixo tempo de processamento, a única exceção foi o modelo de desenvolvimento neural baseado em contornos. O cálculo do laplaciano para toda a imagem necessitava de um número grande de iterações para que a solução se estabilizasse completamente e, a cada movimentação da membrana o laplaciano precisava ser calculado novamente. O tempo médio das simulações realizadas pelo modelo era de aproximadamente $5 h$ para cada figura.

\section{- Discussão dos Resultados}

Neste Capítulo apresentamos hipóteses de desenvolvimento de uma célula e uma nova proposta de um modelo de desenvolvimento neural baseado em contornos. No caso da primeira hipótese, baseada na evolução ao longo da normal, a aquisição de imagens reais de neurônios em crescimento serviu para enriquecer o trabalho, e possibilitou uma investigação sobre essa hipótese. Foi possível observar que os 
pontos de controle escolhidos na seqüencia de imagens quase não possuíam variação ao longo da normal. A evolução por convolução não mostrou-se robusta para a aplicação em imagens reais e a thin plate spline apresentou bons resultados em imagens de evolução simuladas, evidenciando a utilização de minimização de energia. Também apresentamos um modelo simplificado de crescimento de actinas baseado em [Pollard(2000)] e de movimentação da membrana através de uma abordagem de um sistema massa-mola. Os resultados foram satisfatórios, mas serviram para evidenciar a necessidade de um modelo matemático mais robusto para o tratamento dessa situação.

Baseados nesses resultados o trabalho foi finalizado com a implementação do modelo de crescimento baseado em contornos, utilizando a formulação de Snake Balloon, sob a ação da curvatura e de campos elétricos externos, onde o efeito do gradiente do campo elétrico, devido à atividade elétrica de células vizinhas [Lasek(1986), Levitan(1997), Kalil(2000), Matus(2000) e Van Ooyen(2001)], e o fato do crescimento ser evidenciado em regiões de ramificação [Lasek(1986), Futerman(1996), Okabe(1991)] foram características biológicas levadas em consideração pelo modelo proposto. Os resultados obtidos foram satisfatórios no sentindo de gerar estruturas que fossem qualitativamente semelhantes a neurônios reais. Apesar do modelo ainda não possuir uma quantificação dos resultados obtidos com dados experimentais reais de crescimento, é muito importante destacar que os parâmetros utilizados para o crescimento são baseados em fatos biológicos. Também é importante notar que podemos acoplar gradientes de concentrações químicas de diferentes substâncias ao modelo (quimiotropismo). O efeito do campo elétrico está mais intimamente ligado ao encontro da rota pelo neurônio e a seleção dos alvos, e os gradientes de concentrações a seleção do neurônio alvo para conexões. 


\section{CAPÍTULO 7: CONCLUSÕES}

Esse trabalho caracteriza-se como uma importante contribuição aos trabalhos que vêm sendo desenvolvidos no Grupo de Pesquisa em Visão Cibernética na área de neurociência, no sentido que visa apresentar técnicas de caracterização morfológica de células neurais utilizando esqueletos e dimensão fractal, e também hipóteses e modelos de crescimento neural. Neste Capítulo apresentaremos as discussões finais sobre as técnicas neuromorfométricas de medidas extraídas dos neurônios e sobre algumas hipóteses de crescimento desenvolvidas ao longo desse trabalho, destacando as suas qualidades e desvantagens. A seguir temos um breve comentário sobre as colaborações científicas desta tese. Finalizamos com uma discussão sobre as sugestões de trabalhos futuros.

\section{(a) Medidas Neuromorfométricas}

Uma área de estudo muito importante na neurociência é a caracterização e classificação morfológica das células. Geralmente, esses processos são feitos manualmente em vários conjuntos de células, englobando desde a segmentação até a extração de medidas. Um artifício muito utilizado pelos cientistas é a utilização de um dendograma para a representação e caracterização das ramificações dendríticas. Nesta tese foi desenvolvida a utilização da técnica de dilatação exata para a extração de esqueletos multiescala, e posterior extração automática de dendogramas e medidas em células neurais, conforme discutido no Capítulo 5. Uma característica marcante nessa abordagem é a natureza multiescala do método, onde as escalas são representadas pelos raios dos círculos da dilatação.

A técnica de dilatação exata permitiu qualidade e precisão aos esqueletos extraídos das formas neurais, e conseqüentemente às medidas e aos dendogramas desses neurônios. Além disso, o método é rápido, se comparado ao caso manual, e permite a utilização de um amplo conjunto de células neurais, possibilitando um espaço de amostras muito maior nos casos de classificação. As medidas extraídas dos esqueletos das células neurais foram o comprimento, a largura, a área, o ângulo, a 
curvatura e a hierarquia das ramificações. Também obtivemos medidas de ordem e número de ramificação de um conjunto de neurônios. Esses resultados foram apresentamos para as imagens de células ganglionares adultas, Seção 5.3.1.

Outra medida extraída desse mesmo conjunto de células foi a dimensão fractal multiescala. Essa medida foi resultado do aperfeiçoamento do cálculo da dimensão fractal através do uso de dilatações exatas e da extração da derivada da curva do log (area) vs log (raio), uma nova contribuição a essa técnica. A abordagem possibilitou o estudo do valor de dimensão fractal ao longo dos raios de dilatação. Ela também se caracteriza como um método mais preciso para o cálculo da dimensão fractal. Foram construídos gráficos do valor da dimensão fractal e do seu raio de dilatação máximo (para o máximo da dimensão fractal), para as imagens das células ganglionares sob diferentes condições de crescimento (sem a ação de fator neurotrófico e sob a ação do NT4). Entretanto, essa medida não foi suficiente para realizar uma separação de classes nessas células apresentadas.

\section{(b) Modelos de Crescimento}

Uma experiência muito importante nesse projeto foi a geração de seqüências de imagens de células neurais em crescimento. A possibilidade de aquisição de imagens reais de neurônios em crescimento serviu para enriquecer esse trabalho, e possibilitar a implementação de investigações sobre as hipóteses de crescimento biológicas a atuarem sobre o neurônio. Foram realizados experimentos biológicos de cultura de células neurais, com posterior segmentação dessas células e a determinação de pontos de controle e correspondências nas seqüências geradas de forma semiautomática. A aquisição de imagens apresentou alguns contratempos experimentais, pois o equipamento impossibilitava a aquisição constante das imagens, ou seja, o acompanhamento total do processo. O microscópio utilizado não possuía um ambiente controlado onde a célula podia ser mantida de forma adequada.

Apresentamos vários estudos sobre a biologia do desenvolvimento da célula neural, buscando relacionar as características biológicas morfológicas mais relevantes e como poderíamos embutir tais características ao longo das simulações. Uma grande parte dos estudos limitou-se ao entendimento da dinâmica interna da célula, uma vez que se acredita que ela tenha um papel importante no 
desenvolvimento celular. Descrevemos os principais fatores que influenciam na forma final do neurônio, tais como, gradiente de concentrações, campos elétricos, dentre outros. Apresentamos a teoria desenvolvida por Pollard(2000) de crescimento das actinas baseada nas moléculas Arp2/3 e Wasp/Scar como nucleadoras dos filamentos.

O Capítulo 4 iniciou-se com um histórico e uma descrição sobre alguns do métodos mais representativos de simulação neural, as técnicas de simulação funcionais e as de crescimento neural. Nosso maior interesse foi no modelo de crescimento neural baseado na variação da concentração de cálcio desenvolvido por Samuels, Hentschel e Fine [Hentschel(1994), Samuels(1996)]. A sua implementação foi bem difícil e com muitas dificuldades, visto que o artigo apenas mencionava, superficialmente, as equações e não apresentava descrições mais detalhadas sobre alguns passos essenciais do método. O maior problema encontrado foi a evolução da membrana de acordo com os gradientes calculados, o que nos motivou ainda mais a procurar uma abordagem diferente para o tratamento da membrana celular.

A grande vantagem desse modelo é a sua abrangência de simulações de estruturas biológicas (tubulinas, bombas de íons e canais iônicos). Entretanto, ele possui alguns fatores negativos, como por exemplo, manter a concentração externa a célula constante, o que biologicamente não é verdade. Além disso, não possui agentes externos atuando sobre a evolução da célula. O próprio Prof. Hentschel apresentou várias argumentações contrárias ao seu modelo, e às idéias adotadas em seus artigos, questionando se os resultados obtidos seriam realmente respostas biológicas do sistema ou simplesmente artefatos matemáticos advindos das equações utilizadas. Além disso, ele também acredita que o sistema não possui uma grande realidade biológica, visto que somente considera concentrações de cálcio internas a célula.

Neste trabalho, apresentamos uma nova abordagem às técnicas de caracterização do desenvolvimento neural, através da utilização de modelos de evolução baseados em contornos, onde a membrana é tratada como uma curva fechada. Foram usadas técnicas de processamento de imagens e hipóteses biológicas para o desenvolvimento dessas simulações.

O Capítulo 6 apresenta alguns resultados sobre hipóteses de desenvolvimento do neurônio. Em alguns dos casos elas foram aplicadas nas sequiências de neurônios 
reais, fornecendo indícios sobre as forças presentes durante o seu crescimento. Foi possível verificar, através dos resultados apresentados na Figura 33, que a grande maioria dos pontos de controle escolhidos não possuíam evolução ao longo da normal para as células consideradas, pois o histograma de ângulos entre a normal e a direção da velocidade da membrana do neurônio possuía uma distribuição uniforme. O resultado nos leva a crer que os pontos de alta curvatura, escolhidos automaticamente como pontos de controle, não possuem uma evolução ao longo da normal.

No caso da convolução obtivemos um bom resultado para a estimação do núcleo de convoluções para os exemplos obtidos com uma simulação de diversas gaussianas atuando ao longo da curva. Entretanto, para imagens reais, os resultados não foram satisfatórios, pois os contornos possuem um nível de ruído muito grande, impossibilitando a estimação dos núcleos de convolução.

Apresentamos a idéia de thin plate spline e pares de thin plate onde visamos o estudo da modificação da forma em função da energia de dobramento da variação da configuração dos pontos de controle. Esse tipo de medida pode ser útil como um atributo para a caracterização do crescimento do neurônio.

Apresentamos também uma idéia sobre a implementação de um modelo de variação da forma da membrana celular através de um sistema de massa-mola sob a ação de forças restauradoras. O modelo possui uma implementação simples, mas não consegue descrever totalmente o comportamento adotado pela membrana, embora ele consiga descrever o movimento da membrana sob a ação de uma força, que supostamente seria o microfilamento de actina. Apesar de um bom resultado preliminar, um aperfeiçoamento a essa idéia foi a utilização de contornos ativos para a simulação da movimentação da membrana, gerando um grande avanço referente ao equacionamento matemático e também à solução do problema.

Esse trabalho conclui-se com a implementação de um novo modelo de crescimento de célula neural baseado na formulação matemática de contornos ativos, Snake Balloon, sob a ação de curvatura e campo elétrico externo. Os resultados obtidos foram bastante satisfatórios, do ponto de vista qualitativo, pois a variação da forma dos campos elétricos geraram variações na direção de crescimento das ramificações. A curvatura e o campo elétrico atuaram de forma conjunta, gerando estruturas ramificadas semelhantes a neurônios. A vantagem do método é a 
formalização matemática do modelo, possibilitando a adição de restrições ao crescimento, baseadas em idéias biológicas de desenvolvimento. No potencial elétrico, proveniente da atividade elétrica de células vizinhas, e no crescimento por altas curvaturas, referentes aos filamentos de actina. Entretanto, ele ainda não possui características relacionadas a concentração de substâncias no interior celular. Além disso, não realizamos uma análise qualitativa dos resultados obtidos com os da biologia, buscando aproximar o modelo dos dados reais experimentais.

Ao final deste trabalho, conseguimos perceber que ainda existe uma grande complexidade biológica referente ao desenvolvimento da célula neural, de suas estruturas internas e na relação entre elas. Muitos pesquisadores vêm se dedicando ao estudo dessas estruturas visando, no futuro, um completo entendimento da grande maioria desses processos. Dentro dessa linha de pesquisa este trabalho dá uma importante contribuição ao descrever o processo do crescimento neural através de uma nova abordagem baseada em sua forma neural, que apesar de pouco difundida na literatura, apresenta um enorme potencial de aplicação e validação em modelagens neurais.

\subsection{Principais Contribuições}

Este trabalho introduz várias abordagens direcionadas à variação da forma neural, apresenta hipóteses e um modelo de evolução para crescimento de células neurais. Ele inclui também medidas neuromorfométricas já existentes e o aperfeiçoamento de outras. Desse modo, podemos destacar resumidamente as principais contribuições deste trabalho referentes às medidas neuromorfométricas e aos modelos de crescimento, são elas:

(a) Uma validação completa, qualitativa e quantitativa, do cálculo de curvatura utilizando características da transformada de Fourier [Estrozi(1999), Estrozi(2003)]. No caso específico da curvatura analisamos problemas como quantização e precisão dos resultados para variações dos parâmetros de suavização. 
(b) A utilização da teoria de dilatação exata, desenvolvida por [Costa(1999)a], em células neurais. A automatização do dendograma e das medidas extraídas do esqueleto, através da utilização da dilatação exata e do esqueleto multiescala [Costa(2000)a].

(c) Aperfeiçoamento do cálculo da dimensão fractal através do uso da dilatação exata, e da extração da derivada da curva do $\log$ (area) vs log do (raio), trabalho desenvolvido em conjunto com a aluna Silvia C. D. Pinto[Costa(2001), Pinto(2001), Costa(2002)].

(d) Introdução de técnicas baseadas em contornos para modelos de crescimento de células neurais [Bianchi(2001), Bianchi(2003)], com a utilização de hipóteses de desenvolvimento, como evoluções ao longo da normal, por convolução, thin plate spline e curvatura.

(e) O modelo de deformação da membrana celular baseado na força do filamento de actina, com a membrana respondendo a essa movimentação através de uma força restauradora, como de um sistema de molas.

(f) O desenvolvimento de um modelo capaz de gerar estruturas semelhantes a neurônios, a partir da formulação de contornos ativos, e idéias de crescimento ao longo da curvatura e sob o efeito de campos potenciais externos. Foram acopladas ao modelo hipóteses sobre o crescimento biológico.

Além das contribuições citadas acima, o trabalho apresenta uma cuidadosa pesquisa bibliográfica sobre modelos de desenvolvimento de células neurais. Ele encaixa-se em um projeto maior que está sendo desenvolvido no Grupo de Pesquisa em Visão Cibernética desde 1993, sobre a relação forma/função neural, e em modelos de evolução e desenvolvimento.

\subsection{Desenvolvimentos Futuros}

As simulações apresentadas nesta tese abrem vários caminhos para estudos mais abrangentes e completos sobre a construção de modelos de desenvolvimento neural. Dentre os trabalhos a serem desenvolvidos na continuação deste projeto incluímos um aperfeiçoamento do modelo de crescimento de neurônios baseado em contornos 
através da implementação de novas restrições referentes à biologia neural, tais como a variação de concentração de cálcio no interior e exterior celular. Além disso, procurar embutir características estatísticas no modelo, na geração de ramificações iniciais e na variação dos pesos em cada ramificação.

A principal medida a ser tomada como complementação desse trabalho é o aperfeiçoamento dos resultados experimentais obtidos, analisando formas de tornar as células apresentadas mais realísticas e melhor validadas. É muito interessante que se desenvolva uma metodologia quanto a validação quantitativa desses resultados, através de comparações de medidas extraídas das células artificiais, com nossa base de imagens de seqüências de células em desenvolvimento. Essas comparações devem ser feitas ao longo do crescimento, de modo a verificar uma completa concordância entre a simulação e os dados reais.

Podemos também procurar simular casos mais específicos de desenvolvimento, tais como a emergência de ondas de cálcio durante o desenvolvimento do feto, cujo propósito é melhorar a conexão dendrítica entre as células. Seria interessante acompanhar esse desenvolvimento e buscar uma ligação do crescimento dendrítico com a função que este neurônio irá desempenhar.

Posteriormente, uma característica muito interessante a ser acoplada as células é a sua atividade neural, e a sua dinâmica não linear, possibilitando a geração de estruturas neurais completas, quanto à forma e à atividade elétrica desenvolvida. A partir desse momento podemos expandir o trabalho e buscarmos a geração de estruturas mais complexas e realistas, como por exemplo, uma rede de neurônios interconectados e o estudo do comportamento dessa rede neural sob a ação de diversos estímulos.

\subsection{Artigos Publicados em Revistas e Conferências com Arbitragem}

Inferring Shape Evolution, Andrea G. Campos Bianchi, Marinilce F. dos Santos, Dânia E. Hamassaki Britto, Luciano da F. Costa, Pattern Recognition Letters, 24, pp 1005-1014, 2003. 
$1 D$ and 2D Fourier-Based Approaches to Numeric Curvature Estimation and their Comparative Performance Assessment, Leandro F. Estrozi, Luiz G. Rios-Filho, Andrea G. Campos Bianchi, Roberto M. C. Junior, and Luciano da F. Costa, Digital Signal Processing, 13, pp 172-197, 2003.

A Outra Dimensão da Dimensão Fractal, Luciano da F. Costa e Andrea G. Campos Bianchi, Ciência Hoje, vol 31, 183, junho 2002.

Inferring Shape Evolution using Restoration Forces, A. G. C. Bianchi, H. G. E. Henstchel, L. da F. Costa, SIBGRAPI2002 XV Brazilian Symposium on Computer Graphics and Image Processing, Fortaleza, Brasil, 2002.

Accurate Fractal Dimension Estimation in SPM 3D, S. C. D. Pinto, L. da F. Costa, A. G. C. Bianchi, Congresso da Sociedade Brasileira de Microscopia e Microanálise, 2001.

How do neurons grow?, A. G. C. Bianchi, M. F. dos Santos, D. E. HamassakiBritto, L. da F. Costa, World Congress on Neuroinformatics, Austria, 2001.

An Integrated Approach to Shape Analysis: Results and Perspectives, L. da F. Costa, A. G. Campos, e E. T. M. Manoel, International Conference on Quality Control by Artificial Vision, Le Cresout, France, 2001.

A Biologically-Motivated Approach to Image Representation and Its Application to Neuromorphology, L. da F. Costa, A. G. Campos, L. F. Estrozi, L. G. Rios-Filho, A. Bosco, IEEE International Workshop on Biologically Motivated Computer Vision BMCV, 2000.

Inferring Shape Evolution, L. da F. Costa, A. G. C. Bianchi, SIBGRAPI2001 XIV Brazilian Symposium on Computer Graphics and Image Processing, Florianópolis, Brazil, 2001. 
Comparing Curvature Estimation Techniques, L. F. Estrozi, A. G. Campos, L. G. Rios-Filho, R. M. Cesar Jr., e L. da F. Costa, SBAI - Simpósio Brasileiro de Automação Inteligente, 1999.

Glial Cells Analysis Using GNC (Graduated Non Convexity) and Fractal Dimension A. G. Campos, V. M. Lima, W. Hanke, e L. da F. Costa, III Workshop on Cybernetic Vision, Campinas, Brasil, 1999. 


\section{CAPÍTULO 8: REFERÊNCIAS BIBLIOGRÁFICAS}

[Alberts(1994)]Alberts, B. e et al., Molecular Biology of the Cell, Garland Publishing, 3a edição, 1994.

[Albinet(1996)]Albinet, G. e Pelce, P., Computer Simulation of Neurite Outgrowth, Europhysics Letter, vol 33, 569-574, 1996.

[Banker(1991)]Banker, G. e Goslin, K., Culturing Nerve Cells, The MIT Press, $1^{\text {a }}$ edição, 1991.

[Bayley(1990)]Bayley, P. Schilstra, M. e Martin, S., Microtubule Dynamic Instability: Numerical Simulation of Microtubule Transition Properties Using Lateral Cap Model, Journal of Cell Science, vol 95, 33-48, 1990.

[Bianchi(2001)]Bianchi, A. G. C., Santos, M. F. dos, Hamassaki-Britto, D. E, Costa, L, da F., How do neurons grow?, World Congress on Neuroinformatics, Vienna University of Technology, pp. 386-394, Austria, 2001.

[Bianchi(2003)]Bianchi, A. G. C., Santos, M. F., Hamassaki-Britto, D. E., Costa, L. da F., Inferring Shape Evolution, Pattern Recognition Letters, vol 24, 10051014, 2003.

[Blake(1998)]Blake, A. e Isard, M, Active Contours: The Application of Techniques from Graphics, Vision, Control Theory and Statistics to Visual Tracking of Shapes in Motion, Springer Verlag, 1998.

[Bray(1973)]Bray, D., Branching Patterns of Individual Sympathetic Neurons in Culture, Journal of Cell Biology, vol 56, 702-712, 1973.

[Burke(1986)]Burke,R. E., Cullheim, J. W., Glenn, L.L., Dendritic Morphology of Type $\alpha$-Motoneurons in the Cat, in Intrinsic Determinats of Neuronal Form and Function, Proc. of a Meeting on Intrinsic Determinants of Neuronal Form and Function, Bio-Architectonics Centre, Case Western University, 1986.

[Buxbaum(1988)]Buxbaum, R. e Heidemann, S., A Thermodynamic Model for Force Integration and Microtubule Assembly During Axonal Elongation, The Journal of Theoretical Biology, vol 155, 409-426, 1992. 
[Caserta(1990)] Caserta, F., Stanley, H. E., Eldred, W. D., Daccord, G., Hausman, R. E., Nittmann, J., Physical Mechanisms Underlying Neurite Outgrowth: A Quantitative Analysis of Neuronal Shape, Physical Review Letters, vol 64, $\mathrm{n}^{\mathrm{0}}$ 1, 95-98, 1990.

[Castleman(1996)]Castleman, K. R., Digital Image Processing, Prentice-Hall, 1996.

[Cesar(1995)] Cesar Jr., R. M. \& Costa, L. da F., Piecewise Linear Segmentation of Digital Contours in $\mathrm{O}(\mathrm{N} \cdot \log (\mathrm{N}))$ through a Technique Based on Effective Digital Curvature Estimation, Real-Time Imaging, vol 1, 409-417, 1995.

[Cesar(1997)] Cesar Jr., R. M., Costa, L. da F., The application and Assessment of Multiscale Bending Energy for Morphometric Characterization of Neural Cells, Review of Scientific Instruments, vol 68, 2177-2188, 1997.

[Cesar(1999)] Cesar Jr., R. M., Costa, L. da F., Computer Vision Based Extraction of Neural Dendograms, Journal of Neuroscience Methods, vol 93, 121-131, 1999.

[Chen(1985)]Chen, Y.-D., Hill, T., Theoretical Treatment of Microtubules Disappearing in Solution, Proc. of the National Academy of Sciences, vol 82, 4127-4131, 1985.

[Chenyang(1998)]Chenyang, X., Prince, J. L., Snakes, Shapes and Gradient Vector Flow, IEEE Transactions on Image Processing, vol 7, nº 3, 359-369, 1998.

[Coelho(1996)] Coelho, R. C., Costa, L. da F., On the Application of the BouliganMinkwisk Fractal Dimension for Shape Characterization, Applied Signal Processing, vol 3, 163-176, 1996.

[Coelho(1998)]Coelho, R. C., Síntese, Modelagem e Simulações de Estruturas Neurais Morfologicamente Realísticas, Tese de Doutorado apresentada ao Instituto de Física de São Carlos, 1998.

[Coelho(2002)] Coelho, R. C., Costa, L. da F., Realistic neuromorphic models and their application to neural reorganization simulations, Neurocomputing, vol 48, 555-571, 2002.

[Cohen(1991)] Cohen, L. D., On Active Contours Models and Balloons, Computer Vision, Graphics, and Image Processing: Image Understanding, vol 53, $\mathrm{n}^{\mathrm{o}} 2$, 211-218, 1991. 
[Cohen(1993)] Cohen, L. D., Cohen, I., Finite-Element Methods for Active Contours Models and Balloons for 2D and 3D Images, IEEE Transactions on Pattern Analysis and Machine Intelligence, vol 15, nํㅜ 11, 1131-1147, 1993.

[Costa(1994)] Costa, L. da F.; Topographical Maps of Orientation Specificity, Biological Cybernetics, vol 71, 537-546, 1994.

[Costa(1997)] Costa, L. da F.; Novas Perspectivas em Neuromorfometria $e$ Modelagem, Tese de Livre Docência, IFSC, Universidade de São Paulo, 1997.

[Costa(1998)] Costa, L. da F., Cesar Jr., R. M., Neural Cells classification by Wavelets and multiscale curvature, Biological Cybernetics, vol 79, nº 4, 347360, 1998.

[Costa(1999)] Costa, L. da F.; Multidimensional scale-space shape analysis, Proc. of International Workshop on Synthetic-Natural Hibrid Coding and Three Dimensional Imaging, 214-217,1999.

[Costa(1999)a] Costa, L. da F.; Estrozi, L.F.; Multiresolution Shape Representation without Border Shifting, Electronics Letters, vol 35, nº 21, 1829-1830,1999.

[Costa(1999)b]Costa, L. da F., Velte, T. J., Automatic Characterization and Classification of Ganglion Cells from the Salamander Retina, Journal of Comparative Neurology, vol 404, $\mathrm{n}^{\mathrm{o}}$ 1, 33-51, 1999.

[Costa (1999)c] Costa, L. da F.; Cesar Jr., R. M., Coelho, R. C., Tanaka, J. S.; Perspective on the Analysis and Synthesis of Biologically Realistic Neural Networks, invited chapter in Modeling in the Neuroscience: From Ionic Channels to Neural Networks, 505-528, 1999.

[Costa(1999)c] Costa, L. da, Gauss' Law in Image Processing and Analysis via Fast Numerical Calculation of Vector Fields, Real Time Imaging, vol 5, pp 243-251, 1999.

[Costa(2000)] Costa, L. da F. e Cesar Junior, R. M., Shape Analysis and Classification - Theory and Practice, CRC Press, 2000.

[Costa(2000)a]Costa, L. da F., Campos, A. G., Estrozi, L. F., Rios-Filho, L., Bosco, A., A Biologically-Motivated Approach to Image Representation and Its 
Application to Neuromorphology, IEEE International Workshop on Biologically Motivated Computer Vision (BMCV2000), Seoul, Korea, 2000.

[Costa(2001)]Costa, L. da F., Campos, A. G., e Manoel, E. T. M., An Integrated Approach to Shape Analysis: Results and Perspectives, International Conference on Quality Control by Artificial Vision, Le Cresout, France, 2001.

[Costa(2001)a] Costa, L. da F. e Bianchi, A. G. C., Inferring Shape Evolution, SIBGRAPI2001 XIV Brazilian Symposium on Computer Graphics and Image Processing, Florianópolis, SC, 2001.

[Costa(2002)] Costa, L. da F. e Bianchi, A. G. C., A Outra Dimensão da Dimensão Fractal, Ciência Hoje, vol 183, 2002.

[Consularo(2000)] Consularo, L.A. , Técnicas de Mineração de Dados para Análise de Imagens, Tese de Doutorado apresentada ao Instituto de Física de São Carlos, 2000 .

[Davenport(1992)]Davenport, R. e Kater, S., Local Increases in Intracellular Calcium Elicit Local Filopodial Responses in Helisoma Neuronal Growth Cones, Neuron, vol 9, 405-416, 1992.

[Davenport(1996)] Davenport, R., Dou, P., Mills, R. e Kater, S., Distinct Calcium Signalling within Neuronal Growth Cones and Filopodia, Journal of Neurobiology, 31, 1-15, 1996.

[Desai(1997)] Desai, A. e Mitchison, T. J., Microtuble Polymerization Dynamics, Annual Review in Cell Development Biology, 13, 83-117, 1997.

[Dowling(1992)]Dowling, J. E., Neurons and Network: An Introduction to Neuroscience, Harvard University Press, 1ª edição, 1992.

[Estrozi(1999)] Estrozi, L. F., Bianchi, A. G. C., Rios-Filho, L. G., César Jr, R. M., e Costa, L. da F., Comparing Curvature Estimation Techniques, SBAI - Simpósio Brasileiro de Automação Inteligente, 1999.

[Estrozi(2003)]Estrozi, L. F., Rios-Filho, L. G., Bianchi, A. G. C., César Jr, R. M., e Costa, L. da F., 1D and 2D Fourier-Based Approaches to Numeric Curvature Estimation and their Comparative Performance Assessment, Digital Signal Processing, vol 13, 172-197, 2003. 
[Evans(1989)]Evans, W. H. e Graham, J. M., Membrane Structure and Function, IRL Press, $1^{\underline{a}}$ edição, 1989.

[Fromherz(1994)]Fromherz, P. e Schaden, H., Defined Neuronal Arborizations by Guided Outgrowth of Leech Neurons in Culture, European Journal of Neuroscience, vol 6, 1500-1504, 1994.

[Fromherz(1995)]Fromherz, P. e Stett, A., Silicon-Neuron Junction: Capacitive Stimulation of an Individual Neuron on a Silicon Chip, Physical Review Letters, vol 75, $\mathrm{n}^{-0} 8,1670-1673,1995$.

[Futerman(1996)]Futerman, A. H. e Banker, G. A., The Economics of Neurite Outhgrowth- the Addiction of new Membrane to Growing Axons, TINS, vol 19, $\mathrm{n}^{\mathrm{o}}$ 4, 144-149, 1996.

[Gierer(1972)] Gierer, A. e Meinhardt, H, A Theory of Biological Pattern Formation, Kybernetik, vol 12, 30-39, 1972.

[Gonzalez(1987)] Gonzalez, R. C., Wintz, P., Digital Image Processing, AddisonWesley, 3ª edição, 1987.

[Hely(1998)]Hely, T. A., Computational Models for Developing Neural Systems, Tese de Doutorado apresentada a Universidade de Edinburgh, 1998.

[Hely(1998)a]Hely, T. A., van Ooyen, A. e Willshaw, A Simulation of Growth Cone Dynamics Based on Turing Morphogenesis Patterns, Information Processing in Cells and Tissue, 69-73, Plenum Press, 1998.

[Hentschel(1994)]Hentschel, H. G. E., Instabilities in Cellular Dendritic Morphogenesis, Physical Review Letters, vol 73, nํ 26, 3592-3595, 1994.

[Hentschel(1996)]Hentschel, H. G. E. e Fine, A., Diffusion-Regulated Control of Celular Dendritic Morphogenesis, Proc. of Royal Society London B, vol 263, 18, 1996.

[Hentschel(1999)]Hentschel, H. G. E. e Van Ooyen, A., Models of Axon Guidance and Bundling during Development, Proc. of Royal Society London B, vol 266, 2231-2238, 1999. 
[Hill(1984)]Hill, T., Chen, Y.-D., Phase Changes at the End of a Microtubule with the GTP Cap, Proc. of the National Academy of Sciences, vol 81, 67286732,1984 .

[Hoerl(1970)]Hoerl A., Kennard, R., Ridge Regression: Applications to Nonorthogonal Problems, Technometrics, vol 12, nº 1, 69-82, 1970.

[Holy(1994)]Holy, T. e Leibler, S., Dynamic Instability of Microtubules as an Efficient Way to Search in Space, Proc. of the National Academy of Sciences USA, vol 91, 5682-5685, 1994.

[Hubel(1995)]Hubel, D. H., Eye, Brain and Vision, W. H. Freeman and Company, $2^{\mathrm{a}}$ edição, 1995.

[Jennings(1980)]Jennings A., Matrix Computation for Engineers and Scientists, John Wiley \& Sons, 1980.

[Kass(1987)]Kass, M., Witkin, A. e Terzopoulos, D., Snakes: Active Contour Models, in Proc. of First International Conference on Computer Vision, Londres, 1987.

[Kalil(2000)]Kalil, K., Szebenyi, G. e Dent, E., Common Mechanisms Underlying Growth Cone Guidance and Axon Branching, Journal of Neurobiology, vol 44, 145-158.

[Kandel(1985)]Kandel, E. R. e Schwarts, J. H., Principles of Neural Science, Elsevier Science Publishing, 2ª edição, 1985.

[Koch(1989)]Koch, C. e Segev, I., Methods in Neuronal Modeling: from Synapses to Networks, The MIT Press, $1^{\mathrm{a}}$ edição, 1989.

[Kornack(2001)]Kornack, D. R., Rakic, P., Cell Proliferation without Neurogenesis in Adult Primate Neocortex, Science, 294, 7, 2001.

[Kraft(1995)]Kraft, R., Fractals and Dimensions, artigo obtido em http://www.edv.agrar.tu-muenchen.de/dvs/idolon/idolonhtml/idolonhome.html, 1995.

[Lasek(1986)] Lasek, R. J., Black, M. M., Intrinsic Determinats of Neuronal Form and Function, Proc. of a Meeting on Intrinsic Determinants of Neuronal Form and Function, Bio-Architectonics Centre, Case Western University, 1986. 
[Levitan(1997)]Levitan, I. B. e Kaczmarek, L. K., The Neuron: Cell and Molecular Biology, Oxford University Press, $2^{2}$ edição, 1997.

[Machesky(1999)]Machesky, L. M., Insall, R. H., Signaling to Actin Dynamics, Journal of Cell Biology, vol 146, 267-272, 1999.

[Mitchison(1984)]Mitchison, T. e Kirschner, M., Dynamic Instabilities of Microtubule Growth, Nature, vol 312, 237-242, 1984.

[Mogilner(1996)] Mogilner, A. e Oster, G., Cell Motility Driven by Actin Polymerization, Biophysical Journal, vol 71, 3030-3045, 1996.

[Molginer(1996)a] Mogilner, A. e Oster, G. The physics of lamellipodial protrusion, European Biophysical Journal, vol 25, 47-53, 1996.

[Mogilner(1999)] Mogilner, A. e Oster, G., The polymerization ratchet model explains the force-velocity relation for growing microtubules, European Biophysical Journal, vol 28, 235-242, 1999.

[Montague(1991)] Montague, P. R. e Friedlander, M. J., Morphogenesis and Territorial Coverage by Isolated Mammalian Retinal Ganglion Cells, The Journal of Neuroscience, vol 11, 1440-1457, 1991.

[Mullens(1998)] Mullens, R. D., Heuser, J. A., Pollard, T. D., The Interaction of Arp2/3 Complex with Actins: Nucleation, High Affinity Pointed End Capping, and Formation of Branching Networks of Filaments, Proc. of the National Academy of Science of United States of America, vol 55, nº 11, 6181-6186,1998.

[Matus(2000)]Matus, A., Actin-Based Plasticity in Dendritic Spines, Science, vol 290, 754-758, 2000.

[Neimeyer(1984)]Neimeyer, L., Pietronero, L., Weismann, H. J., Fractal Dimension of Dielectric Breakdown, Physical Review Letters, vol 52, nำ 12, 1033-1036, 1984.

[Okabe(1991)]Okabe, S. e Hirokawa, N., Actin Dynamics in Growth Cones, The Journal of Neuroscience, vol 11, nº 7, 1918-1929, 1991.

[Van Ooyen(1999)]van Ooyen, A. \& Willshaw, Competition for Neurotrophic Factor in the Development of Nerve Connections, Proc. of Royal Society London B, vol 266, 883-892, 1999. 
[Van Ooyen(2001)]van Ooyen, A. \& Willshaw, Competition for Neurotrophic Factor in the Development of Nerve Connections: A Review of Model, Network: Computation in Neural Systems, vol 12, R1-R47, 2001.

[Van Pelt(1986)] van Pelt, J. e Verwer, R., Topological properties of Binary Trees Grown with Order-Dependet Branching Probabilities, Bulletin of Mathematical Biology, vol 48, 197-221, 1986.

[Van Pelt(1997)] van Pelt, J. e Uylings, H., Mathematical Modeling of Dendritic Branching, Em Poznanski, R., Mathematical Modeling in Neuroscience: from Ionic Channels to Neural Networks, Gordon e Breach, 1997.

[Pinto(2001)]Pinto, S. C. D. Costa, L. da F., Bianchi, A. G. C, Accurate Fractal Dimension Estimation in SPM 3D, XVIII Congresso da Sociedade Brasileira de Microscopia e Microanálise (CSBMM 2001), Águas de Lindóia, SP, 2001.

[Pinto(2001)a]Pinto, S. C. D. Estimação de Dimensão Fractal em Imagens de SPM, Dissertação de Mestrado apresentada ao Instituto de Física de São Carlos, outubro, 2001.

[Pinto(2001)b]Pinto, R. D., Elson, R. S., Azücs, A., Rabinovich, M. I, Selverston, A. I., e Abarbanel, H. D. I., Extended dynamic clamp: controlling up to four neurons using a single desktop computer and interface, Journal of Neuroscience Methods, vol 108, 39-48, 2001.

[Pollard(2000)] Pollard, T. D., Blanchoin, L. e Mullins, R. D., Molecular Mechanisms Controlling Actin Filametn Dynamics in Nonmuscle Cells, Annual Review in Biophysical Biomolecular Structure, 29, 545-576, 2000.

[Prusinkiewicz(1997)]Prusinkiewicz, P., Hammel, M. e Mech, R., Visual Models of Morphogenesis: A Guided Tour (http://www.cpsc.ucalgary.ca/Redirect/bmv/ vmm-deluxe/TitlePage.html), 1997.

[Purves(1988)]Purves, D. Snider, W. D. e Voyodic, J. T., Trophic Regulation of Nerve Cell Morphology and Innervation in the Autonomic Nervous System, Nature, vol 336, nํㅜ 10, 123-128, 1988.

[Purves(1990)]Purves, D., Body and Brains: A Trophic Theory of Neural Connections, Harvard University Press, $1^{\text {a }}$ edição, 1990. 
[Rall(1986)] Rall, W., Segev, I., Synaptic Integration and Excitable Dendritic Spine Cluster: Structure/Function, in Intrinsic Determinats of Neuronal Form and Function, Proc. of Meeting on Intrinsic Determinants of Neuronal Form and Function, Bio-Architectonics Centre, Case Western University, 1986.

[Samuels(1996)] Samuels, D. C., Hentschel, H. G. E. e Fine, A., The Origin of Neuronal Polarization: a Model of Axon Formation, Phil. Trans. Royal Society London B, 1147-1156, 1996.

[Sandberg(2003)]Sandberg, A., Models of Development, http://www.nada.kth.se/ asa/Work/, 2003.

[Sethian(1999)]Sethian, J. Level Set Methods and Fast Marching Methods: Evolving Interfaces in Geometry, Fluid Mechanics, Computer Vision, and Material Science, Cambridge University Press, 2ª edição, 1999.

[Sheperd(1994)] Sheperd, G. M., Neurobiolgy, Oxford University Press, 3 ${ }^{\text {a }}$ edição, 1994.

[Shepherd(1986)] Shepherd, G. M., Greer, C. A., The Dendritic Spine: Adaptations of Structure and Function for Different Types of Synaptic Integration, in Proc. of Meeting on Intrinsic Determinants of Neuronal Form and Function, BioArchitectonics Centre, Case Western University, 1986.

[Smith(1985)]Smith, G. D., Numerical Solution of Partial Differential Equations: Finite Difference Methods, Oxford University Press, 1985, 3ª edição.

[Stirling(1995)]Stirling, R. V. e Dunlop, S. A., The Dance of the Growth ConesWhere to Next?, TINS, vol 18, nº 2, 111-115, 1995.

[Swindale(1996)]Swindale, N. V., The Development of Topography in the Visual Cortex: a Review of Models, Network: Computation in Neural Systems, vol 7, 161-247, 1996.

[Tanaka(2000)] Tanaka, J. S., Um Modelo Neuromórfico de Estimativa de Orientação e Curvatura, Tese de Doutorado apresentada ao Instituto de Física de São Carlos, 2000. 
[Tanaka(1991)]Tanaka, E., Kirschener, M., Microtubule Behavior in the Growth Cone of Living Neurons during Axon Elongation, Journal of Cell Biology, vol 115, 345-363, 1991.

[Toris(1995)]Toris, C. B., Eiesland, J. L., Miller, R.F., Morphology of Ganglion Cells om the Neotenous Tiger Salamander Retina, The Journal of Comparative Neurology, vol 352, 535-559, 1995.

[Turing(1952)]Turing, A., The Chemical Basis for Morphogenesis, Phil, Transc.of Royal Society London B, vol 237, 37-72, 1952.

[Young(1984)]Young, D. A., A Local Activator-Inhibitor Model of Vertebrate Skin Patterns, Math. Biosciences, vol 72, 51-58, 1984.

[Wässle(1986)]WÄSSLE, H., Sampling of visual space by retinal ganglion cells, In Visual Neuroscience, Cambridge University Press, 1986.

[Weisstein(1999)]Weisstein, E. W., Minkowski-Bouligand Dimension, http://www.treasure-troves.com/math/Minkowski-BouligandDimension.html, 1999.

[Williams(1992)] Williams, D. J. e Shah, M., A Fast Algorithm for Active Contours and Curvatures Estimation, CVGIP: Image Understanding, vol 55, $\mathrm{n}^{\mathrm{o}}$ 1, 14-26, 1992.

[Witten(1981)]Witten Jr, T. A., e Sander L. M., Diffusion Limited Aggregation, a Kinetic Critical Phenomenon, Physical Review Letters, vol 47, nº 19, 1400-1403, 1981. 


\section{APÊNDICE A: ALGORITMO DO MODELO DE CRESCIMENTO NEURAL PROPOSTO POR HENTSCHEL, SAMUELS E FINE.}

Devido a complexidade de implementação, nesta Seção apresentamos um algortimo do modelo de simulação do crescimento neural proposto por [Samuels(1996)]. A membrana é representada por uma curva fechada, em uma grade $2 \mathrm{D}$, cujo estado inicial é um círculo de raio pré-determinado, e com a direção de crescimento da proteína como $\left(v_{\text {protein }}\right)$ alinhados na normal da membrana.

A tensão inicial da membrana é colocada em um nível tal que a condutividade do cálcio seja baixa, assim a sua concentração e a taxa de crescimento são baixas.

O procedimento consiste em partir de uma tensão inicial, calcular as condutâncias que irão produzir novas tensões e realimentar o sistema. Esse processo é repetido iterativamente até que a tensão convirja para um valor dentro da tolerância escolhida. A partir dessa nova tensão, conseqüentemente, serão calculadas uma nova corrente, uma nova distribuição de concentrações para os íons e ocorrerá novamente o crescimento da membrana e assim sucessivamente.

A seguir, apresentamos o esquema representativo dos principais passos do programa de crescimento de neurônios. 
- Esquema Principal

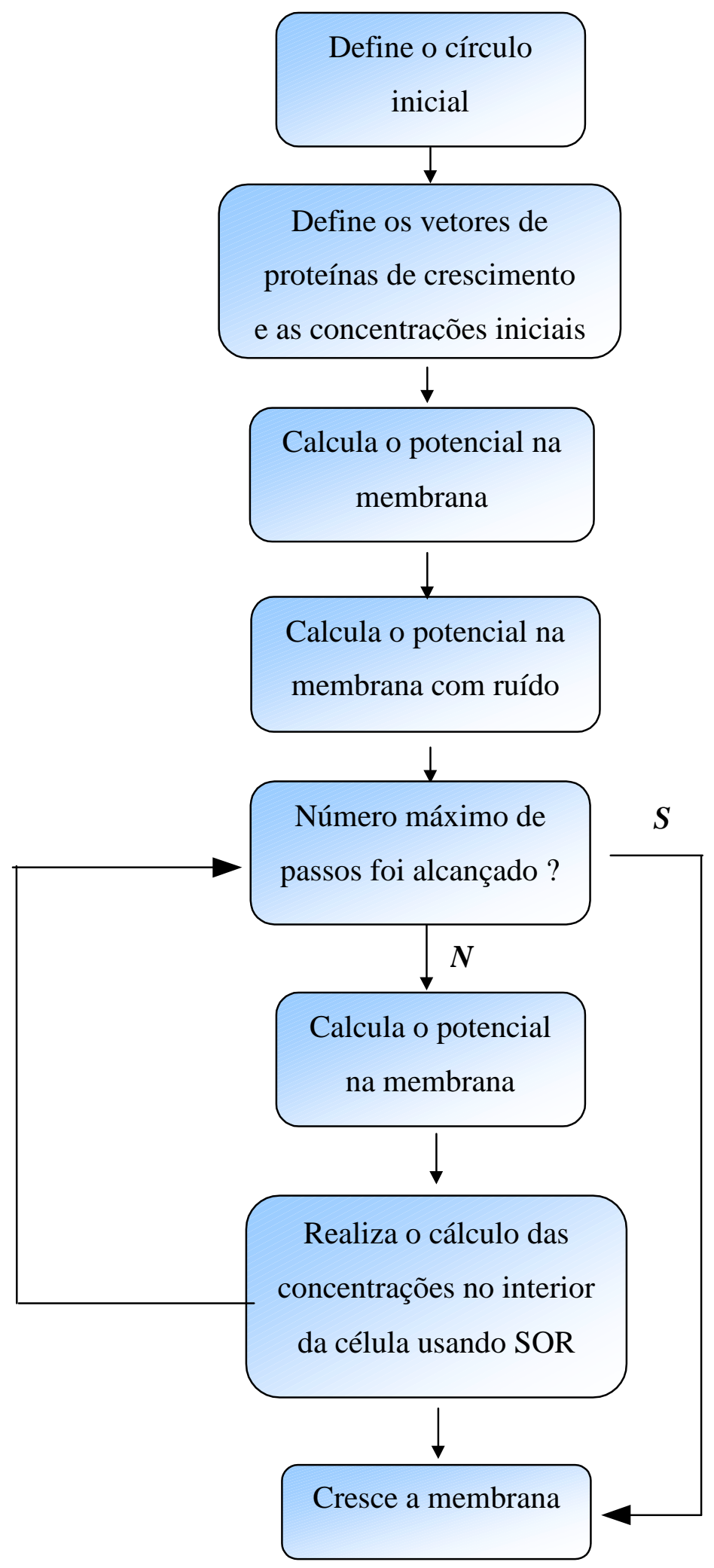

Figura 49 - Esquema representativo do algoritmo utilizado 
Apesar da aparente simplicidade apresentada no esquema acima, o programa caracteriza-se por uma grande complexidade. Cada item da Figura 49 será discutido em maiores detalhes a seguir

\section{- $\mathbf{1}^{0}$ Passo}

\section{Define o círculo inicial}

$\checkmark$ Define as posições na grade dos pontos iniciais da membrana, conforme Figura 50(a)e guarda esses valores em uma lista.

$\checkmark$ A partir desses vetores, define uma matriz de ocupação (mat_oc), onde atribui-se o valor 1 na membrana, -1 em seu interior e 0 fora da estrutura, Figura $50(b)$.

$\checkmark$ Define todos os valores de constantes biológicas utilizadas no programa.

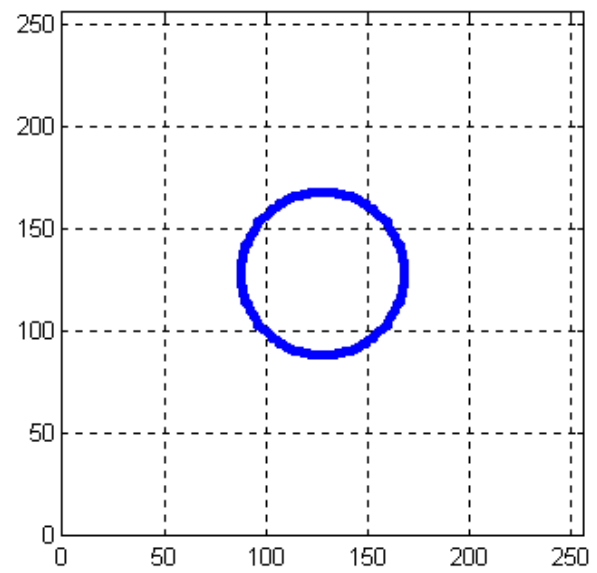

(a)

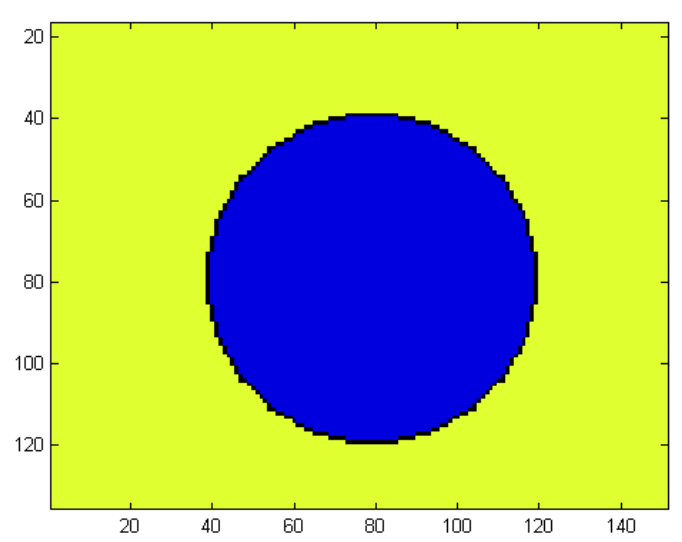

(b)

Figura 50- (a) Membrana inicial definida na grade e (b) matriz de ocupação da membrana. 


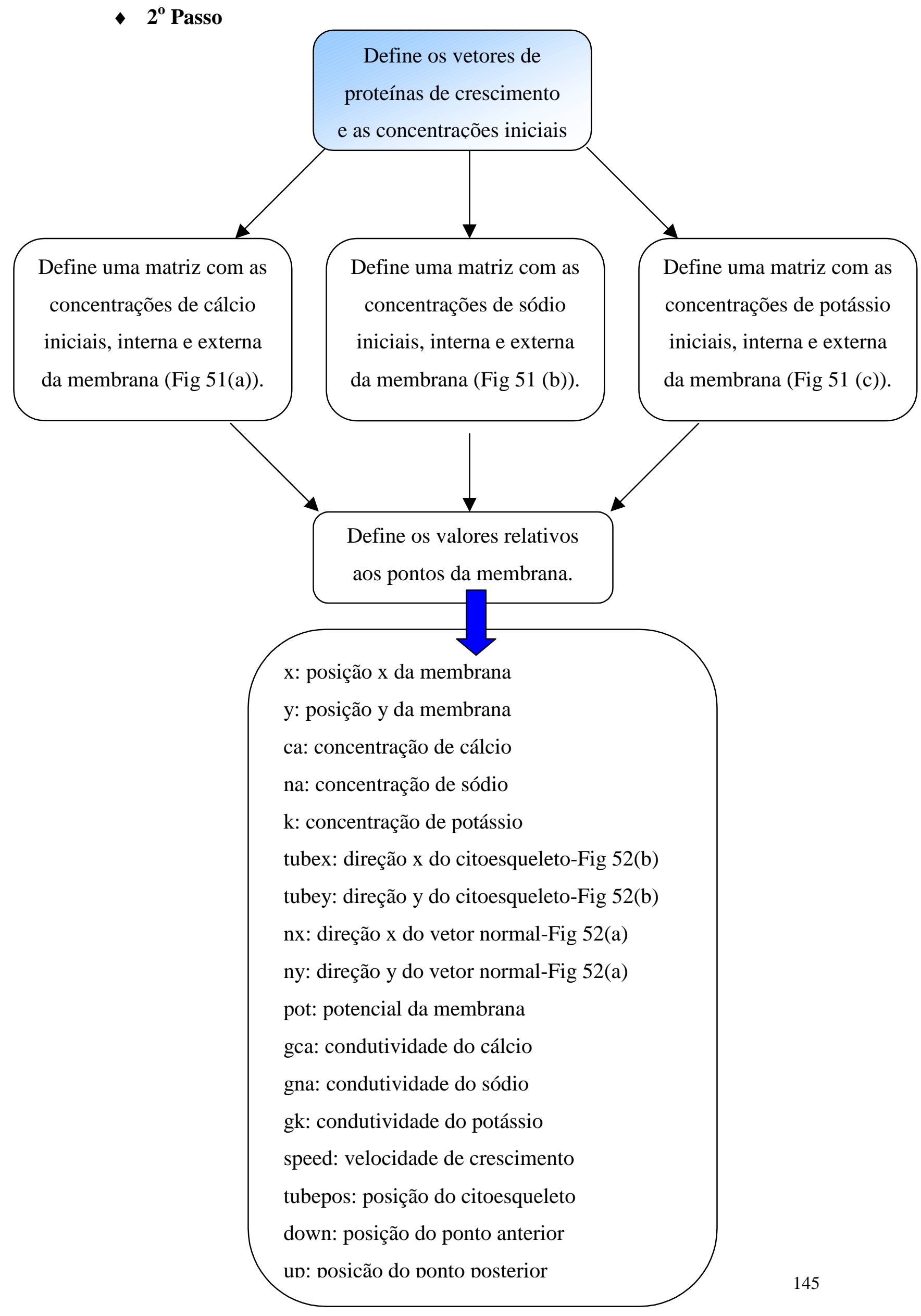




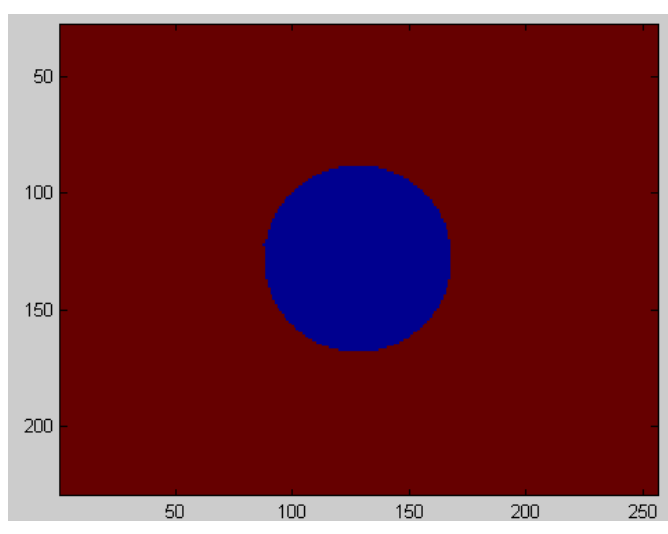

(a)

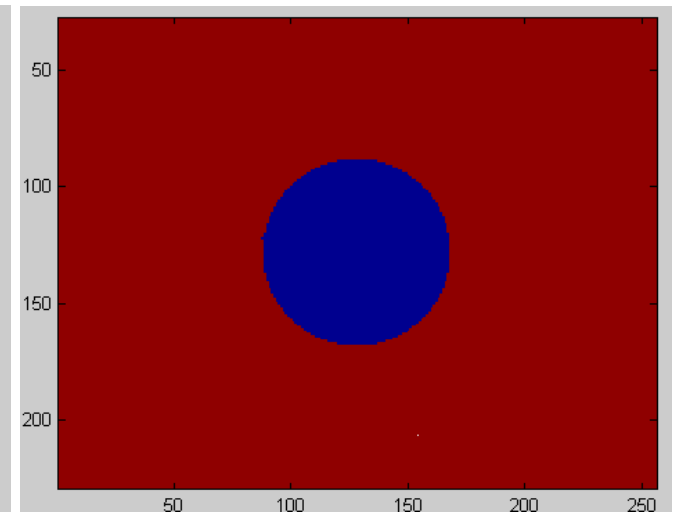

(b)

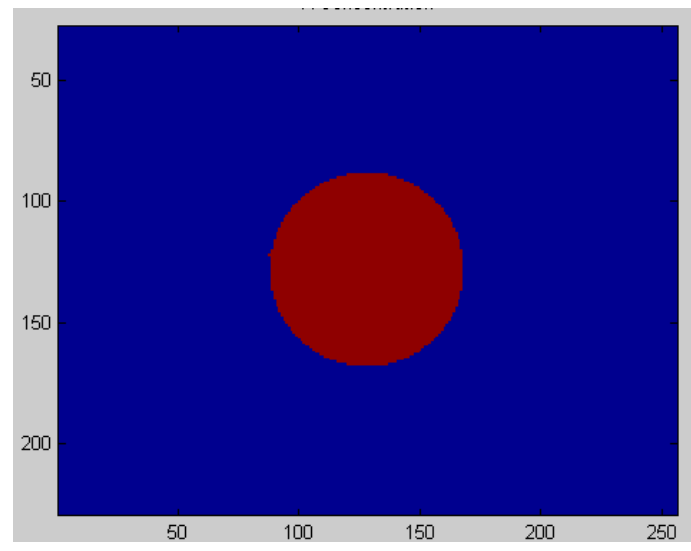

(c)

Figura 51 - (a) Representação da matriz de concentração de cálcio, (b) representação da matriz concentração de sódio e (c) representação da matriz concentração de potássio.

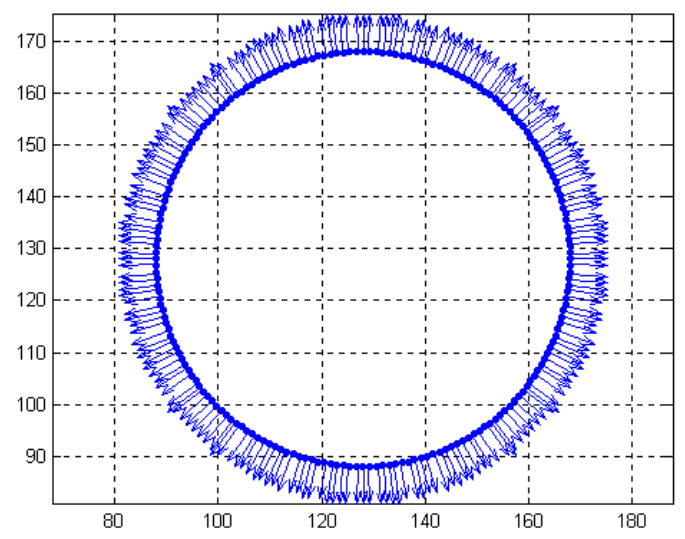

(a)

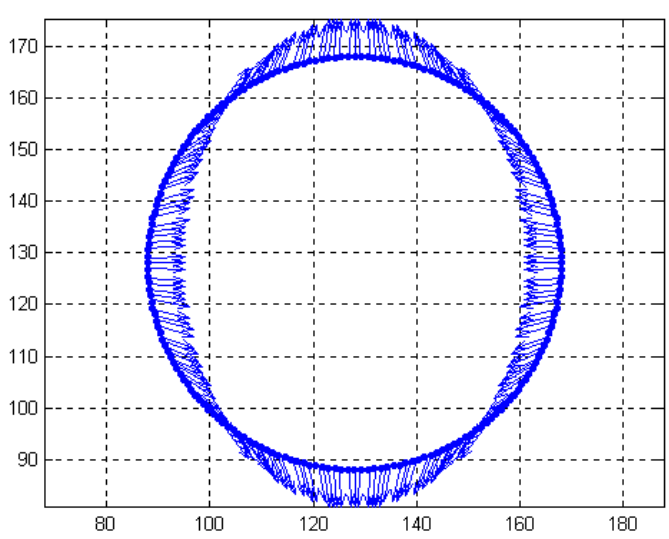

(b)

Figura 52 - (a) Representação dos vetores normais a superfície em cada ponto $(x, y)$ da membrana, em (b) representação da direção dos vetores da proteína tubulina que definem o crescimento em cada ponto $(x, y)$ da membrana. 


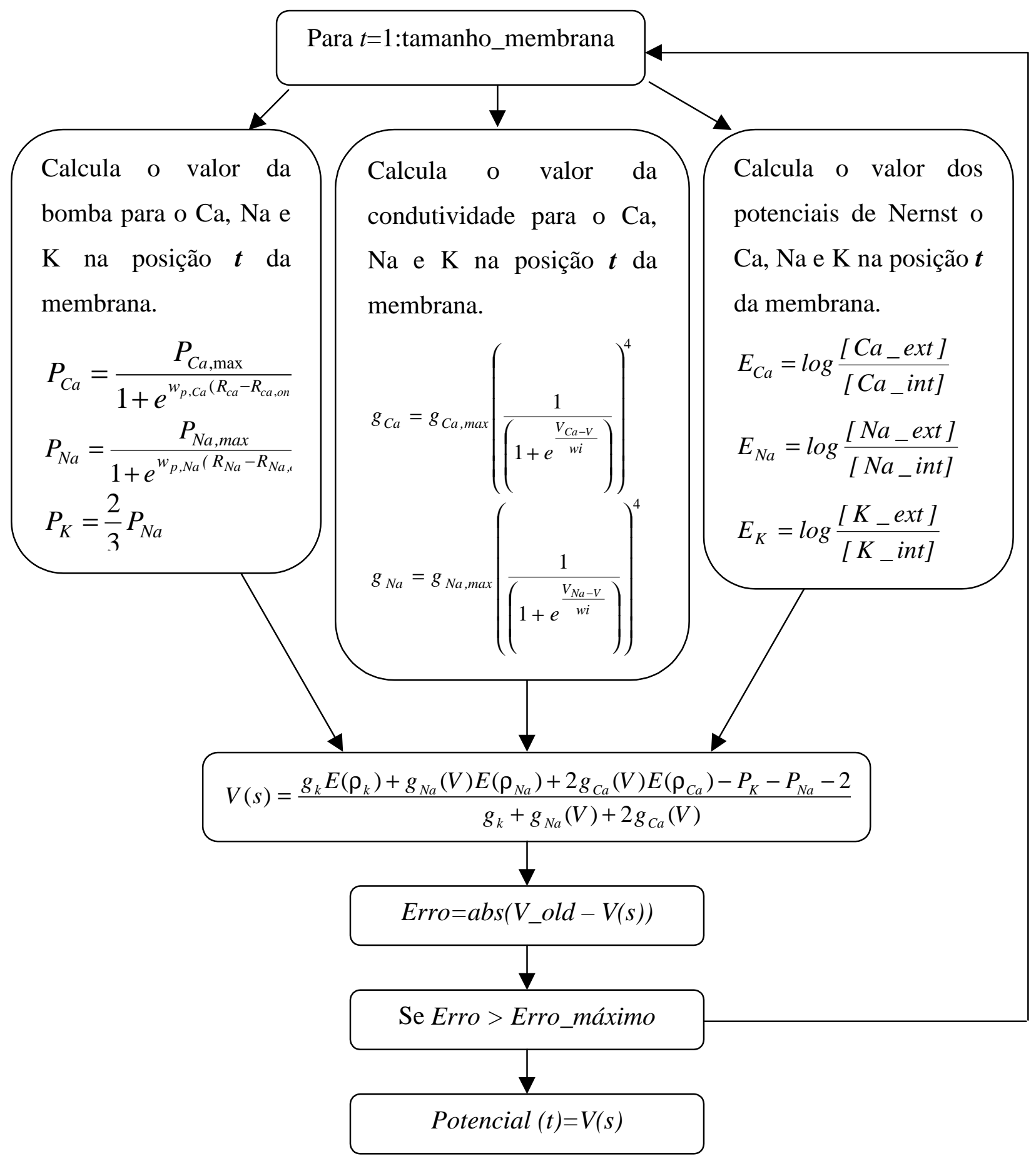




- $\mathbf{4}^{\mathbf{0}}$ Passo $\begin{aligned} & \text { Calcula o potencial na } \\ & \text { membrana com ruído }\end{aligned}$

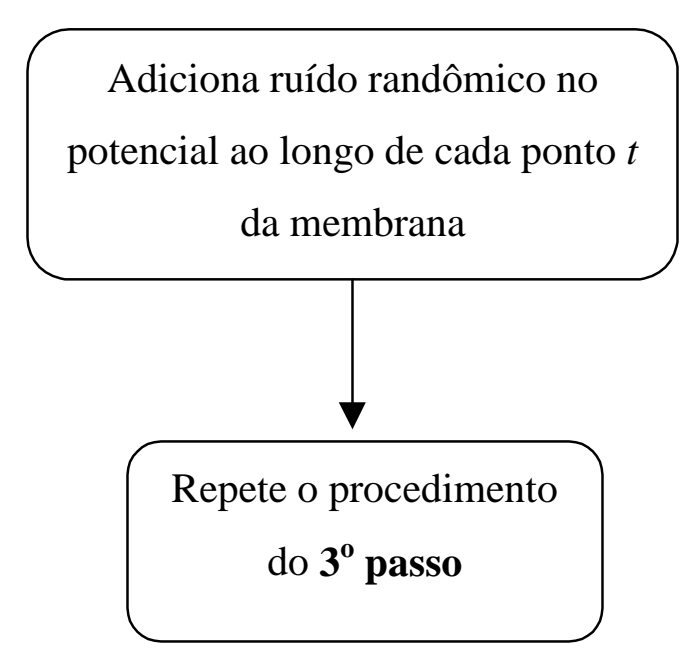

- $5^{\circ}$ Passo

Número máximo de

passos foi alcançado?

$\checkmark \quad$ Início do loop para o crescimento do neurônio, o programa define a condição de parada como sendo um valor pré-definido de iterações. 


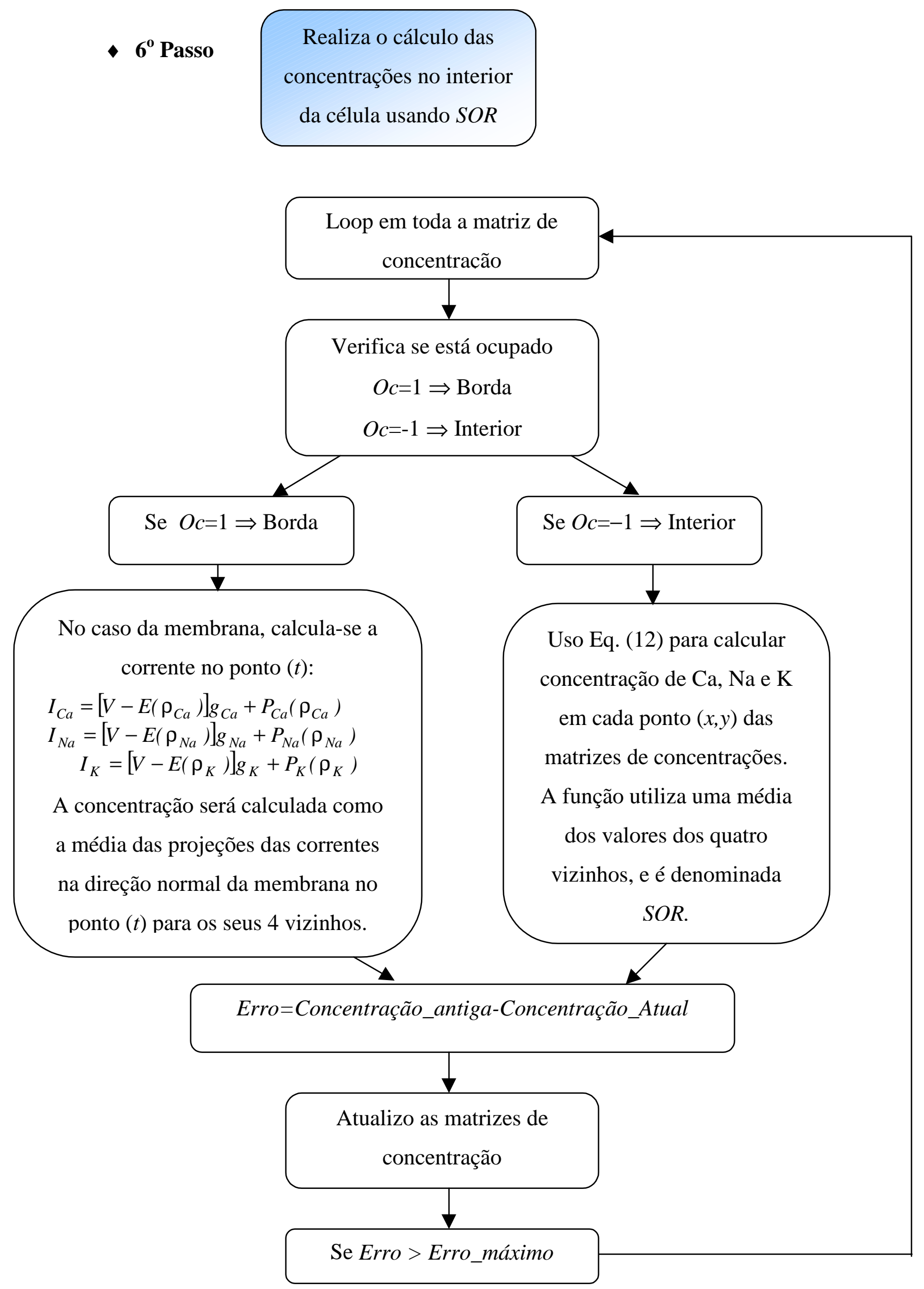


- $\mathbf{7}^{\mathbf{0}}$ Passo Cresce a membrana

Atualiza os valores das concentrações

calculados na lista que representa a membrana

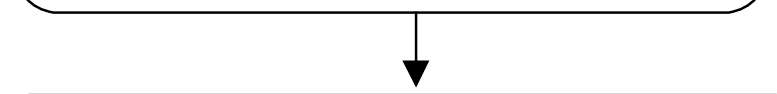

Verifica se os valores da tubulina estão corretos e adiciona uma rotação randômica

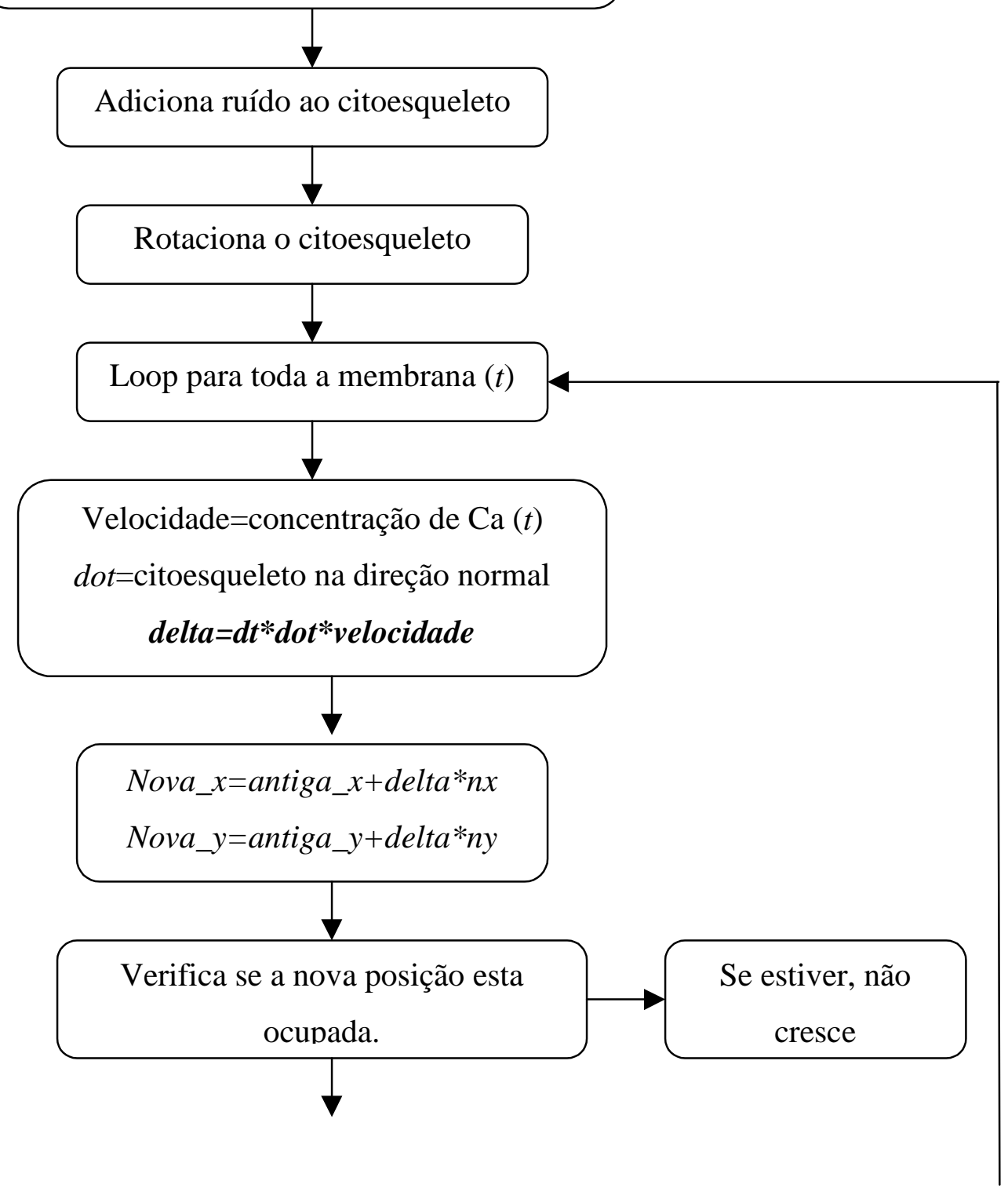




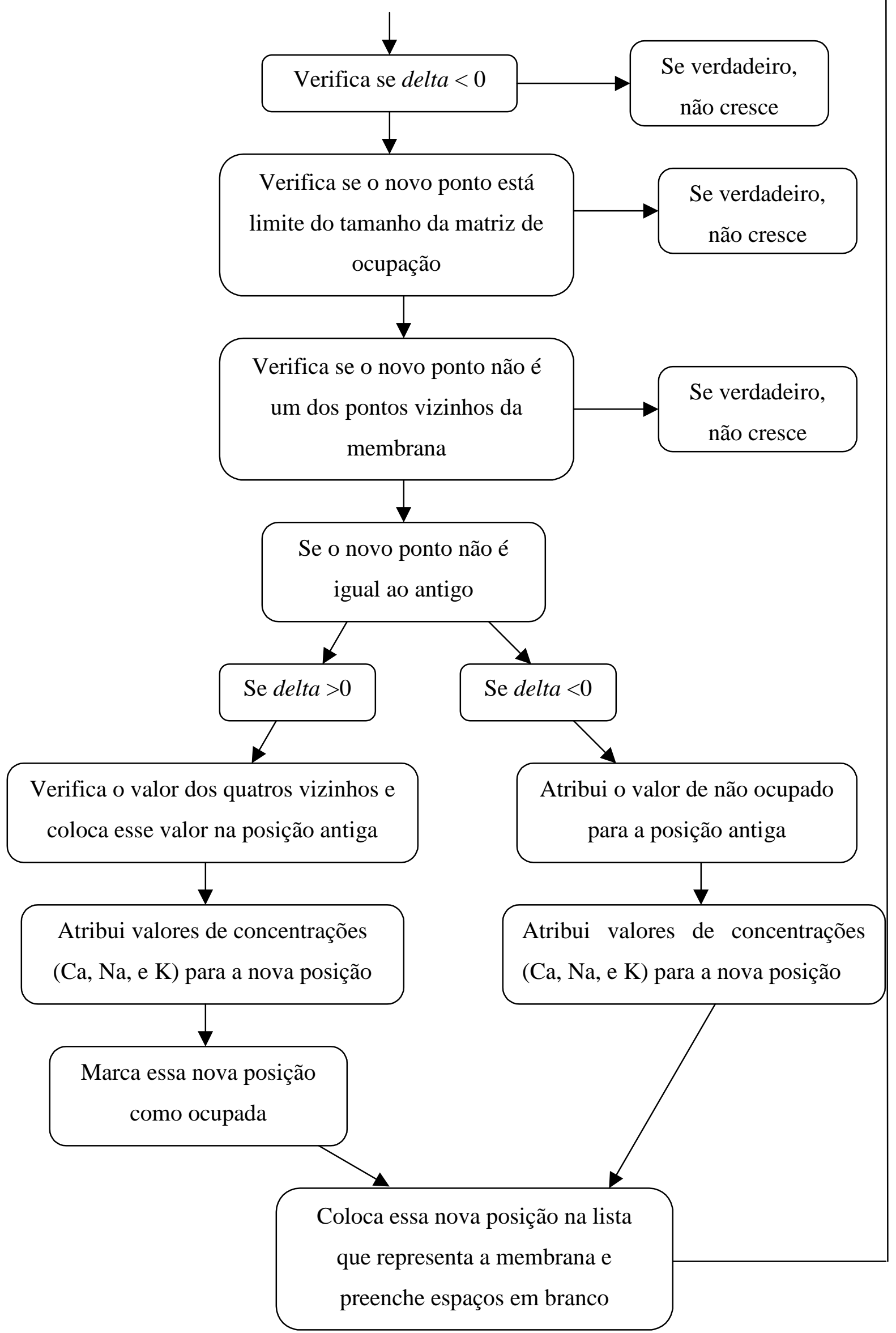




\section{APÊNDICE B: ALGORITMO GREEDY}

Nesta Seção apresentamos uma descrição sobre o algoritmo Greedy, muito utilizado para resolver o funcional definido na Eq. (28) é iterativo e, durante cada iteração os pontos da sua vizinhança são examinados, calculam-se as suas energias e o ponto que possuir a menor energia será escolhido como nova posição para o ponto. A seguir, apresentamos em detalhes o funcionamento do algoritmo e o cálculo de cada energia independentemente. $\mathrm{O}$ algortimo foi desenvolvido para encontrar mínimas energias em funcionais pré-definidos.

Suponha uma imagem de entrada, Figura 53, sobre a qual desejamos rodar o algoritmo de snake e obter o contorno externo do objeto. Iniciamos o nosso programa definindo um conjunto de pontos na imagem (contorno inicial) que desejamos que sofram a ação da snake, são os pontos apresentados em azul na imagem.

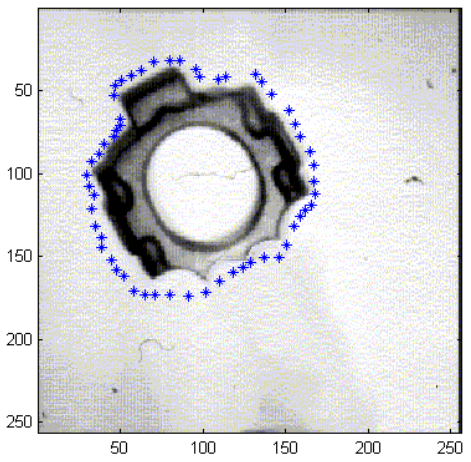

Figura 53 - Imagem original com conjunto de pontos para a snake.

Os pontos em azul definem o vetor $v(s)=(x(s), y(s))$, onde conhecemos os valores de $x$ e $y$ em cada ponto, suponha a existência de $N$ pontos. Devemos também definir vetores correspondendo aos valores de $\alpha, \beta$ e $\gamma$ para cada um desses pontos, normalmente inicia-se o programa $\operatorname{com} \alpha=1, \beta=1$ e $\gamma=1.2$ para cada um dos pontos desse vetor, mas esses valores irão sendo modificados ao longo do contorno.

No caso discreto implementado no computador para cada ponto desse vetor $v\left(s_{i}\right)$ calculamos sua energia e a de seus vizinhos. A Figura 54 apresenta uma ilustração 
dos pontos do vetor $v\left(s_{i}\right)$ e dos vizinhos de cada um desses pontos os $n_{j}$, onde $j$ varia de 1 a $\mathrm{M}$, os pontos em vermelho representam os pontos do vetor nas posições $v(s)$ para $i-1, i$ e $i+1$ e a grade representa os oitos vizinhos do ponto $v\left(s_{i}\right)$.

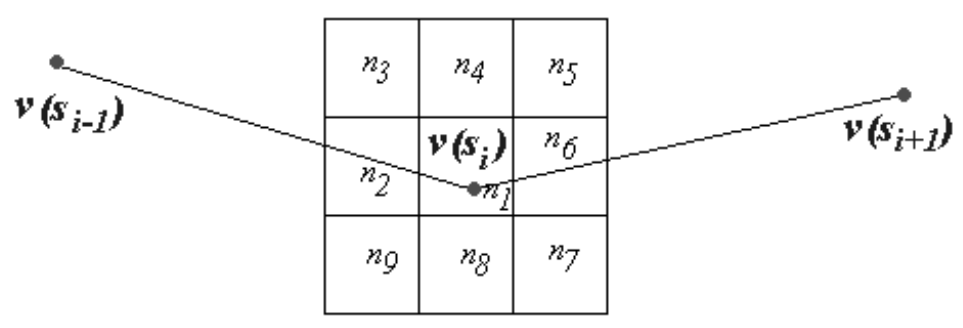

Figura 54- Ilustração dos pontos $v(s)$ e de seus vizinhos.

Um pseudocódigo de como ficaria o algoritmo Greedy é apresentado a seguir com detalhes sobre o cálculo de cada termo do funcional de energia. 


\section{Pseudocódigo}

Inicializa os valores de $\alpha, \beta$ e $\gamma$ para cada ponto $i$;

Loop $/ *$ Loop que move os pontos $v\left(s_{i}\right)$ de lugar

For $i=1: N \quad I^{*}$ Loop que corre todos os pontos do vetor $v(s)$

$E_{\text {mínima }}=$ BIG

For $j=1: M \quad I^{*}$ Loop que corre todos os pontos da vizinhança $(\mathrm{M}=9)$

$\mid$

$$
\boldsymbol{E}_{j}=\alpha_{i} E_{\text {continuidade }, j}+\beta_{i} E_{\text {curvatura }_{j} j}+\gamma_{i} \boldsymbol{E}_{\text {imagem }_{j}}
$$

\section{IF $\mathrm{E}_{\mathrm{J}}<\mathrm{E}_{\mathrm{MIN}}$}

$$
\boldsymbol{j}_{\min }=\boldsymbol{j}
$$

end $/ *$ condição if

end $/ *$ Loop de $j$

Move o ponto $v\left(s_{i}\right)$ para a posição do ponto $j_{\min }$.

end $/ *$ Final do Loop de $i$

/* Agora verifica quais pontos do contorno serão considerados cantos na próxima

/* iteração.

For $i=1: N \quad l^{*}$ Calculo a curvatura pra todos os pontos $i$

$$
\begin{aligned}
\Delta s & =\sqrt{\left(x_{i}-x_{i-1}\right)^{2}+\left(y_{i}-y_{i-1}\right)^{2}} \\
\Delta s+1 & =\sqrt{\left(x_{i+1}-x_{i}\right)^{2}+\left(y_{i+1}-y_{i}\right)^{2}} \\
c_{i} & =\left[\frac{\left(x_{i}-x_{i-1}\right)}{\Delta s}-\frac{\left(x_{i+1}-x_{i}\right)}{\Delta s+1}\right]^{2}+\left[\frac{\left(y_{i}-y_{i-1}\right)}{\Delta s}-\frac{\left(y_{i+1}-y_{i}\right)}{\Delta s+1}\right]^{2}
\end{aligned}
$$

end $/ *$ Final do Loop de curvatura

For $i=1: N / *$ Percorro todos os pontos $i$ para definir quem será canto

$$
\begin{aligned}
& \text { Se curvatura(i)>curvatura (i-1) e curvatura }(i)>\text { curvatura }(i+1) \mathbf{e} \\
& \text { curvatura }(i)>\text { Thresholdcurvatura } \quad \text { e } \operatorname{Imagem}\left(v\left(s_{i}\right)\right)> \\
& \text { ThresholdImagem } \\
& \beta_{i}=0
\end{aligned}
$$

end $/ *$ Final do Loop dos pontos $i$

end $/ *$ Move os pontos até um número pré-definido de iterações ou até que nenhum ponto do contorno $v\left(s_{i}\right)$ se mova. 


\section{$E_{\text {continuidade }}$}

$$
\begin{aligned}
& E_{\text {continuidade }}=\int_{0}^{1} \alpha(s)\left|v_{s}(s)\right|^{2} d s \\
& E_{\text {continuidade }}=\alpha\left(s_{i}\right)\left|v\left(s_{i}\right)-v\left(s_{i-1}\right)\right|^{2}
\end{aligned}
$$

O termo de continuidade de cada ponto é dado pelo valor da derivada no ponto $v\left(s_{i}\right)$ e essa derivada é calculada usando diferenças finitas.

Primeiro calcula-se a distância média entre o pontos $v\left(s_{i}\right)$ para evitar privilégios quanto a alguns pontos, e desse valor é tirado o resultado das diferenças finitas.

$$
\begin{aligned}
& \bar{d}=\sum_{i=2}^{N} v\left(s_{i}\right)-v\left(s_{i-1}\right)=\frac{1}{N-1} \sum_{i=2}^{N} \sqrt{\left(x_{i}-x_{i-1}\right)^{2}+\left(y_{i}-y_{i-1}\right)^{2}} \\
& E_{\text {continuidade }}=\alpha\left(s_{i}\right)\left(\bar{d}-\left|v\left(s_{i}\right)-v\left(s_{i-1}\right)\right|^{2}\right)
\end{aligned}
$$

$\mathrm{Na}$ realidade esse valor de derivada é calculada para cada ponto da vizinhança do ponto $i$, ele é calculado para cada ponto $j$ da vizinhança, então essa energia fica:

$$
E_{\text {continuidade }, j}=\alpha\left(s_{i}\right)\left(\bar{d}-\left|\sqrt{\left(x_{j}-x_{i-1}\right)^{2}+\left(y_{j}-y_{i-1}\right)^{2}}\right|^{2}\right)
$$

Esses valores de energia para os pontos $j$ devem ser divididos pelo valor máximo de energia, de tal modo que dentro dessa vizinhança o valor de energia varie entre 0 e 1 . 


$$
E_{\text {curvatura }}=\int_{0}^{1} \beta(s)\left|v_{s s}(s)\right|^{2} d s
$$

O segundo termo da energia é denominado de termo da curvatura porque o parâmetro utilizado é o comprimento de arco, a curvatura é dada pela segunda derivada da curva, $\left|v_{s s}(s)\right|$.

No caso discreto, teremos que para cada ponto $v\left(s_{i}\right)$ a curvatura é dada pelas equações abaixo:

$$
\begin{aligned}
& E_{\text {curvatura }}=\beta\left(s_{i}\right)\left|v\left(s_{i-1}\right)-2 v\left(s_{i}\right)+v\left(s_{i+1}\right)\right|^{2} \\
& E_{\text {curvatura }}=\beta\left(s_{i}\right)\left|\left(x_{i-1}-2 x_{i}+x_{i+1}\right)+\left(y_{i-1}-2 y_{i}+y_{i+1}\right)\right|^{2}
\end{aligned}
$$

E, devemos também variar os pontos da vizinhança de tal modo que a equação para a curvatura seja dada por:

$$
E_{\text {curvatura }, j}=\beta\left(s_{i}\right)\left|\left(x_{i-1}-2 x_{j}+x_{i+1}\right)+\left(y_{i-1}-2 y_{j}+y_{i+1}\right)\right|^{2}
$$

Esses valores de energia para os pontos $j$ também devem ser divididos pelo valor máximo de energia, de tal modo que dentro dessa vizinhança o valor de energia varie entre 0 e 1 .

$$
\begin{aligned}
& E_{\text {imagem }} \\
& E_{\text {imagem }}=\int_{0}^{1} \gamma(s) E_{\text {gradiente }}(v(s)) d s
\end{aligned}
$$

O terceiro termo é relativo à imagem, e é dado pelo negativo do gradiente da imagem no ponto. 


$$
E_{\text {imagem }}=\gamma\left(s_{i}\right)\left(-E_{\text {gradiente }}\left(x_{i}, y_{i}\right)\right)
$$

Mas antes disso realizamos uma normalização no valor do gradiente em relação a vizinhança $j$ do ponto $i$, ou seja achamos os valores máximos e mínimos em relação aos $M$ vizinhos daquele ponto e realizamos a normalização apenas para esses vizinhos, a normalização é dada por:

$$
\operatorname{im}\left(x_{j}, y_{j}\right)=\frac{\operatorname{imagem}\left(x_{j}, y_{j}\right)-\min (\text { imagem })}{\max (\text { imagem })-\min (\text { imagem })}
$$

Se den $<5 \Rightarrow \min ($ imagem $)=\max ($ imagem $)-5$

A Figura 55, apresenta no item (a) o negativo do gradiente sobreposto aos pontos marcados para o início do algoritmo, em (b) gradiente sobreposto com os pontos originais (azul) e o resultado da snake (vermelho), e (c) a imagem original sobreposta do contorno inicial e do resultado.

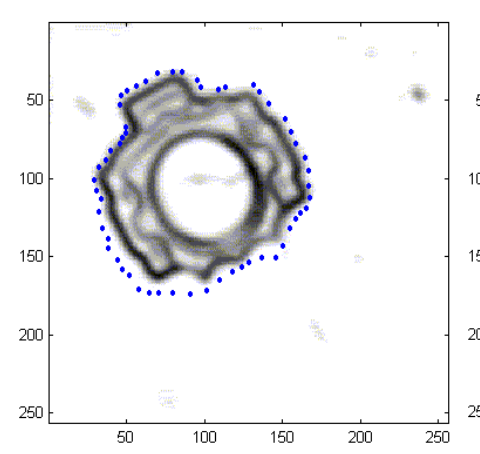

(a)

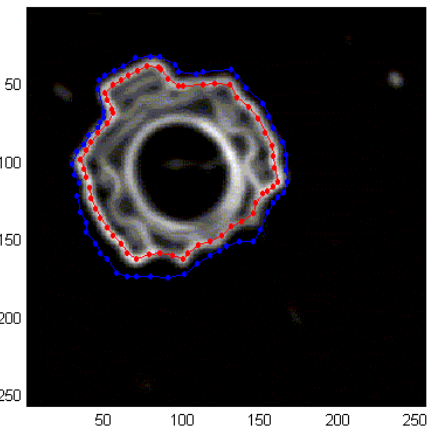

(b)

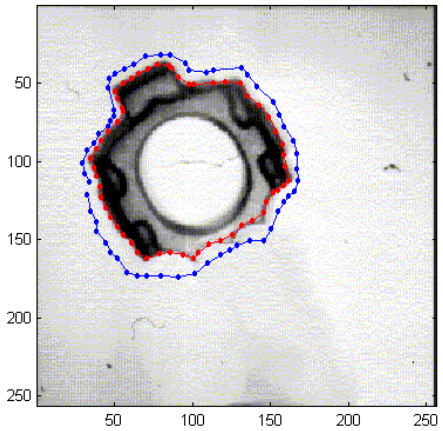

(c)

Figura 55 - (a) Negativo do gradiente sobreposto com os pontos iniciais, (b) e (c) gradiente e imagem original sobrepostos com os pontos originais(azul) e com resultado da snake (vermelho). 


\section{APÊNDICE C: ALGORITMO DE CRESCIMENTO NEURAL BASEADO EM CONTORNOS ATIVOS E POTENCIAL EXTERNO}

Nesta Seção apresentamos uma breve descrição sobre o algortimo utilizado no modelo de desenvolvimento neural desta tese. O modelo de evolução engloba o contorno da célula, como se fosse uma membrana, descrito sob a formulação de contornos ativos, considerando restrições externas e que possuem uma grande analogia aos fatores de crescimento biológicos.

O algoritmo para descrição desse modelo engloba Snake Ballon, curvatura e potencial externo, conforme apresentado no Capítulo 6. O pseudocódigo apresentado a seguir, refere-se aos passos do algoritmo do programa principal. Em seguida, apresentamos em maiores detalhes dois estágios importantes do algoritmo principal. 


\section{Pseudocódigo}

$\Rightarrow$ Leitura de uma imagem inicial com protuberâncias aleatórias definida pelo usuário.

$\Rightarrow$ Extração do seu contorno, gerando o contorno incial e sua centralização

$\Rightarrow$ Geração de uma distribuição de cargas espacial (de acordo com a forma escolhida, circular, em barra, pontual, outras formas neurais e duas formas neurais em conjunto)

$\Rightarrow$ Definção de uma nova imagem através do contorno da distribuição de cargas escolhidas, colocando cargas positivas para a distribuição de cargas e neutra para o contorno.

$\Rightarrow$ Cálculo do laplaciano para essa imagem do contorno e da distribuição de cargas

$\Rightarrow$ Realização da evolução da curva usando a imagem do laplaciano e a Snake Balloon

$\Rightarrow$ Substituição desse novo contorno na imagem de contorno e distribuição de cargas

Enquanto $\mathrm{N}_{\text {ittrações }}<$ Valor Pré-definido faça

Enquanto (Erro $<10^{-8}$ ) faça

Cálculo do laplaciano para a imagem do contorno e da distribuição de cargas Calcula o erro entre essa nova imagem e a anterior à passagem do laplaciano Erro $\leftarrow \operatorname{sqrt}($ Imagem Anterior^2 - Imagem Nova^2)

Realiza a evolução da curva usando a imagem do laplaciano e a Snake Balloon

Substituição desse novo contorno na imagem de contorno e distribuição de cargas Fim do Enquanto

$\Rightarrow$ Caso o número de iterações tenha sido atingido, considera essa última evolução do contorno como o contorno final.

Fim do Algortimo do Programa Principal

Dentro desse pseudocódigo podemos destacar dois itens que necessitam de uma explicação mais detalhada devido a sua complexidade, os itens estão destacados em vermelho e azul. A seguir, apresentamos uma descrição sobre como é feito o cálculo do laplaciano e sobre a evolução das curvas. 


\section{Pseudocódigo}

$\Rightarrow$ O laplaciano é calculado em todos os pontos da imagem que possui o contorno sobreposto da distribuição de cargas considerada.

$\Rightarrow$ A Figura 44 apresenta um exemplo da ação do laplaciano de uma distribuição de cargas circular sob um contorno inicial em preto.

$\Rightarrow \mathrm{O}$ cálculo do laplaciano é feito conforme a equação abaixo, onde neuron é a imagem (matriz) com o contorno e a distribuição de cargas, new_neuron a nova imagem e $l$ e $c$ as respectivas linhas e colunas da matriz.

$n e w_{-}$neuron $(l, c)=(1-\alpha)$ neuron $(l, c)+\frac{\alpha}{4}[$ neuron $(l+1, c)+$ neuron $(l-1, c)+$ neuron $(l, c+1)+$ neuron $(l, c-1)]$

A resolução do laplaciano é feito de acordo com o algortimo de $S O R$ (Sucessive Over Relaxation) [Smith(1985)], onde $\alpha$ um parâmetro de convergência da equação.

\section{Evolução da curva usando a imagem do Laplaciano e a Snake Balloon}

A evolução da curva (contorno) é feita através da definição de um funcional de energia para essa curva, análogo ao do algoritmo Greedy proposto por Williams e Shah [Williams(1992)], da pela Eq. (27).

$$
E=\int_{0}^{1} \alpha(s) E_{\text {continuidade }}(v(s)) \mathrm{d} s+\int_{0}^{1} \beta(s) E_{\text {curvatura }}(v(s)) d s+\int_{0}^{1} \gamma(s) E_{\text {imagem }}(v(s)) d s
$$

Como já comentado anteriormente, Capítulo 6, na Snake Balloon o terceiro termo relacionado a imagem é agora modificado, além do gradiente da imagem, temos também a ação de um termo análogo a uma pressão uniforme e constante ao longo de todo o contorno. O terceiro termo da Eq. (27), que antes se referia apenas a imagem, passa a ser dado pela Eq. (54). 


$$
E_{\text {imagem }}(v(s))=k_{1} \vec{n}(v(s))-k_{2} \frac{E_{\text {gradiente }}(v(s))}{\left\|E_{\text {gradiente }}(v(s))\right\|}
$$

Onde $\vec{n}$ é um vetor unitário na curva no ponto $v(s)$, e $k_{l}$ é a amplitude dessa força. Os valores de $k_{1}$ e $k_{2}$ determinam o peso entre a componente da pressão e a do gradiente. A componente da pressão é dada pela resultante entre o gradiente da imagem do laplaciano e a curvatura na direção normal, conforme representado na Figura 43.

\section{Pseudocódigo}

$\Rightarrow$ Determina o gradiente em todos os pontos do contorno devido a ação da distribuição de cargas.

$\Rightarrow$ Determina o vetor normal aos pontos do contorno, e coloca como módulo o valor da sua curvatura.

$\Rightarrow$ Determina o vetor resultante em cada ponto do contorno, realizando a soma vetorial entre a ação do gradiente e a curvatura do contorno na direção normal.

$\Rightarrow$ A partir da curva (contorno) a ser evoluída gera-se um funcional de energia análogo ao da Snake Balloon.

$\Rightarrow$ Determina os três termos de energia do funcional utilizando a técnica de diferenças finitas para as derivadas e a sua resolução é feita na forma de matrizes.

$\Rightarrow$ Entretanto, no terceiro termo, temos o termo adicional relacionado a pressão, cujo parâmetro é dado pelo vetor resultante calculado entre o gradiente e a curvatura.

$\Rightarrow$ Resolvido esse funcional, geramos novas posições $x$ e $y$ para o contorno. 